\title{
COMPLEJIDAD Y MATERIALIDAD: REFLEXIONES DEL SEMINARIO DEL LIBRO ANTIGUO
}

\author{
C OMPILADORA
}

Idalia García Aguilar

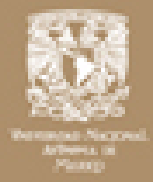

CUADERNOS DE INVESTIGACIÓN 10 
La presente obra está bajo una licencia de:

http://creativecommons.org/licenses/by-ncsa/3.0/deed.es MX

\section{(c) cointive}

Eres libre de:

(15)

copiar, distribuir y comunicar públicamente la obra

(D) hacer obras derivadas

Bajo las condiciones siguientes:

Atribución - Debes reconocer la autoría de la obra en los términos

especificados por el propio autor o licenciante.

No comercial - No puedes utilizar esta obra para fines comerciales.

Licenciamiento Reciproco - Si alteras, transformas o creas una obra a

partir de esta obra, solo podrás distribuir la obra resultante bajo una licencia igual a ésta.

Esto es un resumen fácilmente legible del: texto legal (de la licencia completa)

\section{En los casos que sea usada la presente obra, deben respetarse los términos especificados en esta licencia.}
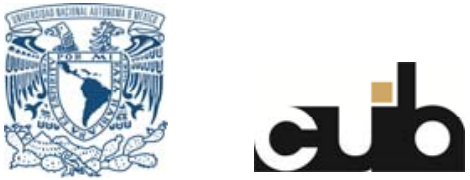
Complejidad y materialidad: reflexiones del Seminario del Libro Antiguo 


\title{
Complejidad y materialidad: reflexiones del Seminario del Libro Antiguo
}

\author{
Compiladora
}

Idalia García Aguilar

Universidad Nacional Autónoma de México 2009 
Z4

C64 Complejidad y materialidad : reflexiones del Seminario del Libro Antiguo / comp. Idalia García Aguilar ; Silvia Salgado Ruelas, Miguel Luque Talaván, Pedro Rueda Ramírez.-México : UNAM, Centro Universitario de Investigaciones Bibliotecológicas, 2009.

xi, 193 p. - (Cuadernos de Investigación; 10) ISBN

Este documento surge a raíz del Seminario del Libro Antiguo, que se inició en 2002.

1.Libros Antiguos 2. Libros Antiguos - Legislación 3. Industria y Comercio Editorial 4. Códice - México I. García Aguilar, Idalia, comp. II. Salgado Ruelas, Silvia III. Luque Talaván, Miguel. IV. Rueda Ramírez, Pedro. V. ser.

\section{Diseño de portada: Mario Ocampo Chávez}

Primera Edición, 2009

DR (C) UnIVERsidad NACIONAL AUtónOMa dE MÉxico

Ciudad Universitaria, 04510, México, D.F.

Impreso y hecho en México

ISBN: 


\section{Contenido}

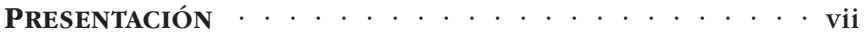
Idalia García

Códices corales sevillanos en México . . . . . . . . . 1 Silvia Salgado Ruelas

De los libros surgen las leyes. Aproximación a los fondos jurídicos de las bibliotecas particulares y públicas novohispanas . . . . . . . . . 65 Miguel Luque Talaván

El comercio de libros en Latinoamérica colonial: aproximación al estado de la cuestión (siglos XVI-XVIII) . . . . . . . . . . . . . . . 193

Pedro Rueda Ramírez 


\section{Presentación}

"La investigación de las regularidades, sustituyó la cartografía de las particularidades"

Roger Chartier (1995)

En el año 2002 surgió el Seminario del Libro bibliotecas Históricas Mexicanas" que se realizó en Cholula bajo el patrocinio de la Benemérita Universidad Autónoma de Puebla y de la Universidad de las Américas-Puebla. Este seminario se fundó con el objetivo de "fomentar y desarrollar trabajos de investigación sobre el libro antiguo como objeto material, que permitan destacar su valor cultural y distinguir su lugar patrimonial dentro del legado cultural mexicano."

Han pasado ya siete años de ese momento especial y en el transcurso de ese tiempo han ocurrido 
Complejidad y materialidad: reflexiones del Seminario del ...

numerosos eventos importantes para fortalecer el espacio académico en los que debo destacar, por un lado, la animosa participación de los miembros del seminario y, por el otro, la valiosa colaboración de los invitados en conferencias y mesas redondas. A éstos últimos en particular, debo agradecer su generosa entrega de los trabajos que se integran en esta compilación.

Sin duda, el libro antiguo es un objeto lleno de complejidades. De ahí, el necesario diálogo interdisciplinario para poder conocer e interpretar los valores textuales e históricos que lo caracterizan. Sin embargo, a pesar del reconocimiento testimonial de nuestro pasado libresco e intelectual, en México es un testimonio relegado como objeto cultural y patrimonial. Este aislamiento del conjunto de bienes que integran el patrimonio cultural de los mexicanos, ha dado por resultado un enorme desconocimiento del valor y representación que el libro antiguo adquiere con el paso del tiempo.

El conjunto de colecciones de libros antiguos, custodiadas en bibliotecas públicas y privadas del país, sigue siendo un territorio sin demarcación cuantitativa ni cualitativa que nos conduzca a largo plazo a consolidar una efectiva política cultural de salvaguarda. Sin ésta, diseñar un futuro deseable para el libro antiguo, similar a las iniciativas internacionales en la materia, sigue siendo una cuota 
pendiente de la acción cultural en nuestro país. Esta deuda se convierte en un deber moral que ahora tenemos con las generaciones venideras.

En efecto, a pesar de una realidad poco alentadora, nosotros aún gozamos del privilegio de conocer y disfrutar de numerosos libros antiguos. Pero sabemos que algunas colecciones no tienen garantía cierta de permanencia, sin importar su valor. Por esa misma certeza, desconocemos el futuro que tendrán algunas ediciones antiguas. No sabemos si éstas tendrán acogida en otra colección y si podremos rastrear su tránsito, o si se guardarán en una caja de cartón esperando un momento más prometedor.

El seminario ha permitido analizar múltiples realidades desde diferentes puntos de vista. También ha permitido que un conjunto de personas interesadas por la salvaguarda del libro antiguo encuentren temas de investigación que reflejen problemáticas concretas de custodia o, en el más afortunado de los casos, evidencien espacios de conocimiento que no han sido considerados en su puntual importancia. Entre éstos, quizá la parte más olvidada sea la relacionada con la materialidad del objeto que conocemos como libro antiguo. Analizar y comprender esa geografía de las hojas, las manchas de oxido, la evidencia de saqueo y destrucción, las encuadernaciones y toda evidencia de 
Complejidad y materialidad: reflexiones del Seminario del ...

posesión y transmisión, entre otros factores, es esencial para delinear la historicidad del objeto.

Todos estos años de actividad han posibilitado un acercamiento, de forma colectiva, al problema patrimonial de la custodia de libros antiguos. En este enorme problema, que aún busca acotar sus fronteras, el conocimiento puntual que aporta la investigación especializada nos ha evidenciado aciertos y carencias en este camino, pero también el mantenimiento de apreciaciones equívocas sobre una parte de la cultura libresca del pasado mexicano.

Este legado, a pesar de todo, sigue presente en diversas preocupaciones de investigación. Los textos que aquí se presentan son muestras de acertados caminos de conocimiento que buscan enriquecer nuestra valoración sobre el libro antiguo, impreso y manuscrito. Estas reflexiones fueron elaboradas para la lectura de los miembros del seminario. Por el interés que generaron y por el compromiso que todo espacio académico tiene con los demás, ahora forman una unidad que se ha ordenado según el tiempo de su presentación. La fortuna ha querido que este criterio, meramente cronológico, coincidiera diseñando un eje temático que nos conduce del libro manuscrito al libro impreso y de ahí a un estado de la cuestión sobre el conocimiento de la historia del libro. 
No me queda más que agradecer a Manuel de Santiago Hernández, director de la Biblioteca José María Lafragua y miembro del Seminario del Libro Antiguo desde su fundación, por haber creado un espacio en la red para todos; a Iván Pérez, quien gestiona y diseña la información de ese mismo espacio; a todos y cada uno de los miembros del seminario por su confianza y paciencia que hacen de la coordinación del seminario una tarea gratificante; y a los tres colaboradores de esta edición por sus valiosas líneas que nos invitan a adentrarnos en el fascinante mundo de la complejidad y la materialidad que ofrece el libro antiguo.

Idalia García Aguilar 


\title{
Códices corales sevillanos en México
}

\author{
SILVIA SALGADO RUELAS
}

\begin{abstract}
Ta Biblioteca Nacional de México, el Museo Nacional del Virreinato y la Iglesia Catedral Metropolitana de la ciudad de México resguardan veinte grandes códices corales que se copiaron e iluminaron por artesanos y artistas del libro en Sevilla. Se trata de 14 cantorales catedralicios y 6 libros conventuales elaborados en el final del siglo XVI y el inicio del XVII.

La liturgia católica practicada en la ciudad de México se nutrió especialmente de las formas y usanzas desarrolladas por la Iglesia Catedral de Sevilla, así como de aquellas que provenían de los franciscanos de la andaluza provincia bética. Si bien el ritual católico romano era el oficial y reconocido desde el Concilio de Trento (1545-1563), la fuerza y antigüedad de la tradición religiosa hispana cobró presencia innegable en la liturgia celebrada por la Nue-
\end{abstract}


Complejidad y materialidad: reflexiones del Seminario del ...

va España. Este argumento se sustenta en la abundante presencia de fiestas dedicadas tanto a los santos hispanos, como son la misa de la aparición del apóstol Santiago, los oficios del aragonés san Pascual Bailón y de la niña santa Eulalia, además de las devociones practicadas en tierras ibéricas, tales como la fiesta de la Virgen de los dolores, la Inmaculada Concepción o la de san José confesor.

Hallazgos recientes vienen a fortalecer la idea anterior, que consiste en la identificación de Juan de la Mota - fraile del Convento Grande de San Francisco en Sevilla, y contemporáneo de la familia de los iluminadores Lagarto-, como el copista de seis cantorales que se conservan en la Biblioteca Nacional de México y en el Museo del Virreinato, en Tepotzotlán. Pese a que no se conoce el nombre de los artistas que iluminaron los libros en cuestión, es notable que el estilo manierista con que fueron elaborados, tiene la impronta hispalense.

Por otro lado, la catalogación de los libros de coro de la Catedral de México permitió identificar tradiciones artísticas, así como artesanos y artistas del libro que participaron en su confección. Uno de los hallazgos más importantes para la historia del libro y del arte hispanoamericano ha sido la identificación de 14 libros de coro de la última década del siglo XVI $(1593,1594)$, con las características estipuladas en el contrato hecho entre dos vecinos de Sevilla, el ilumi- 
nador Diego de Zamora y Melchor Riquelme, escritor e iluminador de la librería coral de la catedral hispalense, entre 1583 y 1599. Además, se encontró recientemente el testimonio del pago y recepción de dichos cantorales en actas del cabildo catedralicio mexicano, del año 1595.

Con estas noticias nos encontramos frente al trasiego de gente, libros e imágenes por la "Mar Océano", que vinieron a dar forma y a enriquecer la creación de libros manuscritos de tradición europea en el Nuevo Mundo.

\section{La liturgia}

Los libros de coro son parte fundamental de la liturgia católica que consiste en el culto que la institución religiosa ha sistematizado con la intención de venerar y alabar a Dios. Sus textos se basan en las Sagradas Escrituras y el breviario romano aprobado por el Concilio de Trento (1542-1563) y la música se inscribe en la tradición del canto llano. La misa y el oficio divino son dos de sus principales ingredientes que se basan en las Sagradas Escrituras. Con la misa se recrea el sacrificio y la promesa de salvación cristiana a lo largo del año, que inicia en el Adviento; en tanto que con el oficio se celebran y consagran las obras divinas, mediante la oración, la lectura, la música y el canto, a lo largo del día, en 
Complejidad y materialidad: reflexiones del Seminario del ...

ocho horas canónicas que son completas, maitines, laudes, prima, tertia, sexta, nona y vesperas. ${ }^{1}$

Desde los inicios de la Edad Media se desarrollaron distintas formas de liturgia cristiana, por lo que es posible distinguir tradiciones como la romana, la gálica, la hispana y la ambrosiana.

Durante la Alta Edad Media, la liturgia romana y gálica ganó fuerza debido, entre otros factores, a que la institución papal y la imperial habían concentrado y proyectado su poder en forma más eficaz sobre las otras tradiciones; sin embargo, la hispana o mozárabe se continuó practicando, al punto que en el siglo XVI, el cardenal Ximénez de Cisneros "fundó la capilla mozárabe en la Catedral de Toledo", ${ }^{2}$ donde aún se conserva.

1 Mario Righetti. Historia de la liturgia. Madrid: BAC, 1955-1956, Ismael Fernández de la Cuesta. Historia de la música española. Madrid: Alianza, 1988, Ismael Fernández de la Cuesta, "El libro litúrgico hasta el Concilio de Trento”, pp. 401-431, en VV. AA. Historia del libro ilustrado... Madrid: Fundación Germán Sánchez Ruipérez, Pirámide, 1993, VV. AA. (1972), Diccionario de historia eclesiástica de España. Madrid: Instituto Enrique Flórez, CSIC, 1972. Véase la entrada de Liturgia. Las horas canónicas son las siguientes: completas es a las 21 horas, maitines a las doce de la noche, laudes a las tres de la mañana, prima es a las 6 de la mañana, tercia es a las 9 horas, sexta es a las 12 del mediodía, nona es a las tres de la tarde, vesperas es antes de ocultarse el sol.

2 Rafael Camacho. Disertación sobre la importancia del canto gregoriano. Guadalajara: Antigua Imprenta de Rodríguez, 1878, p. 52. 
En la Baja Edad Media, los franciscanos tuvieron un papel fundamental para la propagación de la liturgia romana, pues desde el año 1209 asumieron el oficio divino de la curia papal, lo difundieron por Europa y después por América, a través de sus libros. ${ }^{3}$ La Orden de los Hermanos Menores fue fundada por Francisco de Asís (1182-1226) y su primera intención fue la de ser mendicante y no monástica, o sea que se propusieron salir al mundo y predicar la palabra de Dios.

Sus primeros receptores fueron los nuevos burgueses, surgidos en el "Otoño de la Edad Media", quienes se distinguían por ser artesanos, mercaderes y hombres libres. La imagen de San Francisco se vinculó a los que desarrollaban trabajos manuales, actividades infravaloradas durante el Medioevo, pero estimadas en la Edad Moderna.

Sin embargo, en la declaración hecha por el Papa Nicolás III a ese documento, se matizó que aquellos dedicados al oficio divino o al estudio no tenían que trabajar corporalmente, puesto que la labor

3 Francisco de Asís. Regla de los frayles... México: en casa de Pedro Balli, 1595, h. 6.

4 Johann Huizinga. El otoño de la Edad Media. Madrid: Alianza, 1990, capítulo XII, pp. 239-242. 
Complejidad y materialidad: reflexiones del Seminario del ...

espiritual y "las cosas que son del alma exceden a las del cuerpo". ${ }^{5}$

Por otra parte, la Regla de los frailes menores, aprobada por el Papa Inocencio XI en 1209, establece en el capítulo III que: "Los clérigos hagan el Oficio Divino, según la orden de la santa Iglesia de Roma, sacado del Psalterio: del cual podrán haber Breviarios". 6

La celebración diaria de los oficios divinos y los votos de pobreza son dos de los pilares de la Orden; sin embargo, la declaración del Papa Nicolás III sobre la pobreza franciscana y la posibilidad de poseer algo, aclara que ciertos libros, como los breviarios, podían ser usados, más no poseídos, por los regulares, ya que servían al cumplimiento del rito: "porque dice en la regla, que los clérigos hagan el oficio divino, del cual podrán haber Breviarios. De aquí se demuestra manifiestamente, que sus frayles habían de haber uso de Breviario, o de los libros que fuesen convenientes al divino oficio"?

También quedó escrito que ningún fraile podría cobrar o recibir dinero interesadamente, a cambio

5 En Francisco de Asís. Libro de la Regla... Sevilla: Clemente Hidalgo, 1607, h. 15.

6 Ibid., h. 6.

7 Ibid., h. 11. 
de sus obras, materia que constituye el capítulo IV de su Regla. ${ }^{8}$ Ese asunto hizo que el Papa declarara que los bienes muebles e inmuebles, usados por los franciscanos, pertenecieran a la Santa Sede y por lo mismo su compra, venta o enajenación no podría ser hecha directamente por fraile alguno, sino que tendría que ser aprobada por los ministros generales o provinciales de la Orden. ${ }^{9}$

Además de la Regla y el Testamento atribuidos a Francisco de Asís, la Orden de los Hermanos Menores ha producido y aceptado otros documentos que definen sus principios y acciones. Algunos de esos instrumentos han sido escritos por los papas, o bien, se han elaborado en los distintos capítulos generales y provinciales, que constituyen las reuniones oficiales de la Orden.

En la segunda mitad del siglo XVI, tiempo del Concilio de Trento y de la Contrarreforma, los franciscanos se congregaron en distintas ocasiones y ciudades, donde acordaron una serie de normas, como son sus estatutos y constituciones, que permiten conocer los usos que hicieron de los libros litúrgicos, en esos tiempos.

8 Ibid., h. 6.

9 Ibid., h. 14v. 
Complejidad y materialidad: reflexiones del Seminario del ...

Para las constituciones generales del Capítulo celebrado en la ciudad de Salamanca, el año de 1553, se observa que la práctica del oficio divino no era homogénea, puesto que no todos los conventos seguían el rito romano; sin embargo, en el Capítulo general realizado en Valladolid, el año de 1565, se ordenó seguir lo establecido en el Concilio de Trento y unificar el oficio divino, conforme al breviario romano. ${ }^{10}$

En el año 1571, el Capítulo general, celebrado en el Convento de Aracœli en Roma, estableció que los frailes rezasen el oficio divino conforme al breviario y al nuevo calendario romano. ${ }^{11}$ Ocho años después, en 1579, en el Convento de San Francisco de París se realizó el Capítulo, donde se eligió a fray Francisco de Gonzaga, como el ministro general de la Orden. ${ }^{12}$

Durante su gestión se elaboraron dos documentos vinculados directamente con los franciscanos novohispanos:

1. En el Capítulo general intermedio de Toledo del año 1583 se reformaron los Estatutos generales de Barcelona, que regulaban la vida conventual de la familia franciscana cismontana, a la que estaban

10 Ibid., h. 103.

11 Ibid., h. 107.

12 Ibid., h. 110. 
adscritos los frailes hispanos y los de las Indias occidentales. ${ }^{13}$

2. La compilación de la historia de la orden franciscana, con el nombre De Origine Seraphicae Religionis Franciscanae (Roma, 1587), y la parte que correspondió a la historia de la Provincia del Santo Evangelio de México fue escrita por fray Jerónimo de Mendieta, cronista de la Nueva España.

En esos documentos se estableció que en la educación de los novicios, el maestro debía enseñarlos en la doctrina cristiana, en la Regla, así como en las declaraciones de Nicolás III y Clemente V. Además, las primeras materias aprendidas eran el rezo del oficio divino, la oración y la contemplación. ${ }^{14}$ Después, los novicios podían ser coristas o cantores, pero seguían bajo la tutela del maestro de novicios hasta que se ordenaban.

Todos los frailes tenían la obligación de acudir al coro y participar del oficio divino. La conducta que

13 En la Colección mexicana de la Biblioteca Nacional de México se conservan seis ejemplares de esos Estatutos, impresos en 1585 por Pedro Ocharte, en la ciudad de México, lo que significa que es el impreso novohispano del siglo XVI con mayor número de copias que ahí se resguarda. Véase Jesús Yhmoff. Los impresos mexicanos del siglo XVI en la Biblioteca Nacional de México. México: UNAM, 1990, pp. 216-218.

14 Véanse los "Estatutos de Barcelona", en Francisco de Asís, op cit., h. 55. 
Complejidad y materialidad: reflexiones del Seminario del ...

debían tener ahí estaba regulada y se amonestaba a aquellos que al alabar a Dios, tuvieran "gestos livianos y cantos disolutos, y quebrados". La forma correcta de cantar era "a tracto, según la divina costumbre, comenzando, prosiguiendo, y pausando juntamente, $y$ los que en esto fueren defectuosos sean gravemente penitenciados". ${ }^{15}$

En cuanto a los votos de pobreza, los Estatutos de Barcelona confirmaban que era lícito el uso de los libros necesarios para el ministerio de los oficios divinos, pero no lo era tener más de los precisos. ${ }^{16}$

Finalmente, los frailes que vivían en las Indias occidentales, estaban obligados a observar esos Estatutos, en lo que no fuera contrario a las constituciones provinciales del Nuevo Mundo.

Un punto de interés que se introdujo en ellos, para la Iglesia católica indiana es el siguiente:

Iten se ordena, que los que hubieren nacido en la Indias (que vulgarmente se llaman criollos) no puedan ser recIbídos en nuestra orden sino fuesen en caso que hubiese grande testimonio de la virtud y bondad del que ha de ser recIbído, y de su recepción habrá grande edificación en el pueblo: y para que ninguno de los dichos criollos pueda recibir el hábito de nuestra orden,

15 Ibid., h. $57 \mathrm{v}, 58$.

16 Ibid., h. 61. 
sino hubiere cumplido primero veinte y dos años de edad, la cual parece ser competente para poder juzgar si convenga recibir a los dichos criollos en nuestra orden. ${ }^{17}$

En esos años, era casi imposible que los indios o los mestizos profesaran la carrera sacerdotal en la Nueva España, así que el camino eclesiástico quedó abierto sólo a los hispanos y a los criollos; sin embargo, se consideró a los últimos menos capaces de ejercer la labor religiosa.

El año 1596, la ciudad de Vitoria fue escenario del Capítulo donde se expidieron las constituciones de la Congregación, que contenían las normas que regulaban el paso de los frailes hispanos a las Indias. La Real Hacienda, instancia que pagaba el viaje y la manutención de los frailes peninsulares en América, no estaba en condiciones para ello, ni dispuesta a financiar toda la empresa, lo que hizo disminuir el paso de hispanos a la Indias.

En el Capítulo general celebrado en el Convento de Sancta Maria de Aracœli, de Roma, el año 1600, se estatuyó lo siguiente:

Todos los frayles que pasan a las Indias, sean obligados a dar cuenta al Vice Comisario de las Indias, que reside en San Francisco de Sevilla, de

17 Véanse los "Estatutos generales de los frayles de las Indias", en Francisco de Asís. Regla de los frayles..., h. 86. 
Complejidad y materialidad: reflexiones del Seminario del ...

todas las cosas que llevan para el servicio y culto divino (como son ornamentos, imágenes, libros escolásticos, y libros para el Coro). ${ }^{18}$

En ese artículo se observa que los propios frailes llevaban a América, los instrumentos bibliográficos y objetos de arte que requería el oficio divino, $y$ el Convento de San Francisco, en Sevilla, era el sitio donde los franciscanos tenían que hospedarse antes de ir, y allí debían informar de los bienes que pasarían al Nuevo Mundo. ${ }^{19}$

En el Capítulo general de Toledo, del año 1606, el Estatuto para las Indias ordenó el cese de conflictos entre los frailes hispanos y criollos. La crisis de la Iglesia católica indiana era visible a todas luces, pues las disputas entre los mendicantes, así como las que enfrentaban con el clero secular, habían dejado a los regulares hispanos en desventaja numérica frente a los frailes criollos, quienes habían crecido cuantitativamente y peleaban por la proporcionalidad para ocupar cargos principales. En Toledo se intentó paliar inútilmente esa desigualdad, que perduró a lo largo de los siglos XVII y XVIII.

18 Ibid., h. 126.

19 María José del Castillo. El convento de San Francisco, Casa Grande de Sevilla. Sevilla: Diputación provincial, 1988. 


\section{La liturgia en la Nueva España}

En cuanto al uso de libros litúrgicos para el clero secular novohispano, hay que mencionar lo estatuido en los cuatro concilios provinciales y diocesanos realizados durante la época virreinal, el primero, en la Capilla de San José del Convento Grande de San Francisco y los otros tres en la Catedral de México. El primero (1555) y el segundo (1565) se hicieron bajo el patrocinio del arzobispo fray Alonso de Montúfar, OP, con el objeto de aclarar y ordenar muchos de los problemas y cuestionamientos que implicaban la consolidación de la iglesia católica indiana.

En el Concilio I se establecieron noventa y tres capítulos sobre disciplina eclesiástica, correcciones de abusos e instrucción de los indios. ${ }^{20}$ En el Capítulo LXXIV se sanciona con la excomunión a aquel que "imprima libros, ni obra de nuevo sin licencia, ni las así impresas venda, y que ningún mercader ni librero venda libros, sin que primero muestre las memorias de ellos, y sean examinados por el diocesano, o por quien él lo cometiere". ${ }^{21}$ Tal mandato

20 Basilio Arrillaga. "Introducción”, p. iii, en Concilio III Provincial... México: Eugenio Maillerfert Eds., 1859.

21 Concilios provinciales primero y segundo... México: en la Imprenta del Superior Gobierno de el Br. D. Joseph Antonio de Hogal, 1769, pp. 140-150. 
Complejidad y materialidad: reflexiones del Seminario del ...

incluyó a los libros litúrgicos escritos por frailes e indígenas, en lenguas vernáculas, que no hubieran recibido la aprobación necesaria, así como aquellas obras que la Inquisición hubiera señalado como peligrosas.

Para el ámbito de las artes, el capítulo XXXIV estableció "Que no se pinten imágenes, sin que sea primero examinado el pintor, y las pinturas, que pintare". ${ }^{22}$ Tal reglamentación determinaba que la autoridad eclesiástica definía y evaluaba las actividades del gremio de pintores, situación que los obligó a organizarse y proponer sus propias Ordenanzas en 1557, ante el cabildo respectivo. ${ }^{23}$

En el Concilio Segundo Provincial Mexicano, de 1565, se dictaron veintiocho capítulos, entre los que destaca el primero que a la letra dice: "Que los prelados guarden, y manden guardar lo ordenado, y mandado por el Santo Concilio Tridentino". ${ }^{24}$ Sin embargo, aún no habían llegado el misal y el breviario que mandaba observar el Concilio, por lo que en el Capítulo XIV se ordenó "Que se hagan los oficios divinos conforme a lo sevillano... hasta tanto, que venga el breviario y misal, de que se hacen

22 Ibid., pp. 91-92.

23 Manuel Toussaint. Pintura colonial en México. México: UNAM, 1990, pp. 33-38, 220-226.

24 Concilios..., Op. cit., capítulo I, p. 188. 
mención en el libro de el Santo Concilio Tridentino" ${ }^{25}$ Este mandato se debió a que la diócesis mexicana fue sufragánea de la hispalense, hasta 1547, por lo que sus oficios divinos y misas se hacían conforme a la iglesia hispalense. ${ }^{26}$

En el Concilio Tercero Provincial Mexicano de 1585, realizado bajo la presidencia del arzobispo Pedro Moya de Contreras, se estatuyó uno de los códigos más completos de derecho canónico para la iglesia mexicana. En el Título XV, De la celebración de las misas y de los divinos oficios, se manda que "se conformen enteramente en la celebración de las misas y rezo del oficio divino al Misal y Breviario publicados por decreto del Concilio Tridentino, y a lo establecido en sus iglesias con tal que en nada se oponga al Misal y Breviario Romano". ${ }^{27}$ Cabe advertir que en ese tiempo ya se tenían ejemplares impresos de los libros litúrgicos oficiales por lo que era motivo de excomunión no seguirlos.

En el Concilio Cuarto Provincial Mexicano (1771), presidido por el arzobispo Lorenzana, además de reiterar el uso de la liturgia romana tridenti-

25 Ibíd., capítulo XIV, p. 196.

26 María del Carmen Alvarez. El mundo del libro en la catedral de Sevilla. Sevilla: Universidad de Sevilla, 1992.

27 Concilio III Provincial..., Op. cit., "De las cosas piadosas y religiosas", título XV, p. 299. 
Complejidad y materialidad: reflexiones del Seminario del ...

na, se introdujo el uso del manual toledano para la administración de los sacramentos. ${ }^{28}$ Finalmente, la liturgia católica que se practicó en México, durante los siglos XVI al XVIII, estuvo determinada por el Concilio de Trento y la Contrarreforma, aunque se observan atisbos de la liturgia practicada en las catedrales de Sevilla y de Toledo.

\section{La música sacra}

Los libros litúrgicos de canto llano para la misa y el oficio divino son distintos. Los textos de la misa se encuentran en el libro llamado el misal que recoge "las fórmulas completas de la misa". Mientras que aquellos del oficio divino tienen su base en "el salterio o libro bíblico de los salmos, para los cantos, y los restantes libros de la Biblia, para las lecturas. El libro de los salmos fue completado con oraciones y antífonas". Eso significa que, a través del tiempo, el salterio se transformó en el Antiphonarium offici, libro que contiene los cantos del oficio divino, excepto los himnos.

Posterior al antifonario se formó el breviario que contiene todas "las fórmulas y todos los ritos del ofi-

28 Concilio provincial mexicano IV... Querétaro: Imprenta de la Escuela de Artes, 1898, p. 156. 
cio”. M. Huglo señala que el concepto de antífona es un nombre de origen griego que significa canto repercutido o vox reciproca, ya que se canta alternadamente por los cantores, quienes se dividen en dos grupos y se colocan enfrentados, del lado de la Epístola y del Evangelio respectivamente.

La antífona es una pieza breve con uno o dos versículos de la Biblia, que enmarcan un salmo. A su vez, Ismael Fernández ha definido al antifonario como "el libro que contiene no sólo las antífonas, sino todas las piezas cantadas en la liturgia. Es el libro propio del cantor" ${ }^{29}$ En cuanto al concepto de responsorio, su origen es italiano y se trata de un canto breve o redundante realizado por un cantor, a quien responde otro cantor, después de una lectura bíblica, y al responsorio le sigue una antífona o un versículo.

Por otra parte, el himno litúrgico es un canto compuesto en verso métrico o rítmico, organizado en estrofas cantadas con un timbre melódico e introduce un elemento poético. Cabe decir que la división litúrgica que observa el Archivo Musical de la Catedral de Sevilla es de antifonarios para los li-

29 Michel Huglo. Les livres de chant liturgique. Brépols : Turnhout, 1988, pp. 19, 21, 23, 27. Ismael Fernández de la Cuesta, Op. cit., 1988, pp. 110, 233 y 241. 
Complejidad y materialidad: reflexiones del Seminario del ...

bros del oficio divino y de graduales para los libros de la misa. ${ }^{30}$

En México, la ubicación física de los coros conventuales siguió la fórmula hispana de "la tradición tardomedieval de las iglesias conventuales, con profundo presbiterio y amplio coro en alto a los pies del templo". ${ }^{31}$ Esa situación modificó la colocación de los cantores, pues no se hallaban en el altar mayor sino en lo alto y al fondo del templo.

Uno de los aspectos señalado por los cronistas del primer siglo virreinal novohispano es el de la música y el canto europeos que los indígenas mexicanos aprendieron de los misioneros, desde la época de los frailes Pedro de Gante y Juan Caro, en los conventos de Texcoco y de México. Esas fueron dos de las artes que mayor aceptación recibieron en el Nuevo Mundo, al punto que su demanda tuvo que ser reglamentada, pues un gran número de indios se integraron a esas actividades.

En el Concilio Primero Provincial Mexicano del año 1555, el capítulo LXVI estableció: "Que se modere la música, e instrumentos, y que no haya es-

30 Mario Vázquez. "Presentación”, en J. Ayarra et al. Archivo musical de la S. I. Catedral de Sevilla. Sevilla: [s.n.], 1995.

31 Pedro Navascués. Monasterios de España. Madrid: Espasa Calpe, 1988, v. 1, p. 8. Jorge Alberto Manrique. "El arte novohispano...”, en Una Visión del arte y de la historia. México: UNAM, 2001, v. 3, p. 54. 
cuelas donde no hubiere religiosos o clérigos, que tengan cuidado de ellas" ${ }^{32}$ En esta sentencia se observa claramente que la Iglesia asumía el control de la enseñanza y el desarrollo musical novohispanos, así como el número de sus ejecutantes, por lo que ciertamente logró imprimir su sello a lo largo de la época virreinal.

En ese Concilio se advirtió que el "exceso grande, que hay en nuestro arzobispado, y provincia, cuanto a los instrumentos musicales de chirimías, flautas, vigüelas de arco, y trompetas, y el grande número de cantores, e indios, que se ocupan en los tañer, y en cantar, nos obliga a poner remedio...", por lo que se encargó a "todos los religiosos, y clérigos de nuestro arzobispado, y provincia, que señalen, y limiten el número de los cantores, que en cada pueblo, donde residen, puede haber, de manera, que no queden, ni hayan sino los muy necesarios, y estos canten bien el canto llano, y este se use, y se modere, y ordene el canto de órgano al parecer de el diocesano...". ${ }^{33}$

Cabe recordar que en esos años la Iglesia mexicana, seguía muy de cerca lo que la Catedral sevillana practicaba, pues todavía en el Concilio Segundo Provincial Mexicano (1565) se estableció que la Ca-

32 Concilios provinciales primero y segundo..., Op. cit., capítulo LXVI, pp. 140-141.

33 Ibid., p. 141. 
Complejidad y materialidad: reflexiones del Seminario del ...

tedral de México y sus iglesias sufragáneas "canten en el coro, y hagan el oficio mayor y menor conforme a los misales nuevos, y breviarios de la dicha iglesia de Sevilla", ${ }^{34}$ en tanto que no se tuviera la publicación aprobada por la Santa Sede, de dichos libros litúrgicos en América.

En 1570, fray Alonso de Montúfar (O.P.), arzobispo de México, prescribió las Ordenanzas para el coro de la catedral de México, que sirvieron como base normativa al resto de las iglesias novohispanas y en ellas se "describen las ceremonias de la más importante iglesia del Nuevo Mundo". ${ }^{35}$ Ese mismo año, el oidor de la Real Audiencia, Alonso Zorita, parafraseando a Hernán Cortés, informó al rey Felipe II, que entre los indios había "muchos cantores y músicos... saben leer y escribir y hacer bien sus libros de canto llano y de canto de órgano con muy hermosas letras en los principios. Ellos los encuadernan, y hay muchos latinos". ${ }^{36}$

34 Ibíd., capítulo XIV, p. 196.

35 E. J. Burrus, "Introducción”, p. 15, en Alonso de Montúfar. Ordenanzas para el coro de la catedral de México. Madrid: Eds. José Porrúa Turanzas, 1964.

36 Alonso Zorita. Breve relación de los señores de la Nueva España, Mexico, p. 129. Citado por Jesús Estrada. Música y músicos de la época virreinal. México: SEP, Diana, 1973, p. 24. Véase también Robert Ricard. La conquista espiritual de México. México: FCE, 1995. 
En ese testimonio se observa la estrecha relación que existía entre los que cantaban, copiaban e iluminaban los libros corales; y aunque hay pocas noticias sobre indios que compusieran la música, como es el caso de Juan Matías (hacia 1618-1666 o 1667), zapoteco nacido en San Bartolo Coyotepec, quien fue maestro de capilla de la Catedral de Oaxa$\mathrm{ca},{ }^{37}$ parece ser que antes del año 1700 , la música sacra que se tocaba en la Nueva España provenía principalmente de la Península Ibérica, que llegaba a través de libros y músicos europeos; sin embargo, del siglo XVIII se tienen documentos que señalan el desarrollo de la música sacra compuesta por novohispanos, que se cantaba y tocaba en las iglesias y conventos. ${ }^{38}$

En el año 1667, la Constitución de la Provincia franciscana del Santo Evangelio en México, no se había alejado de la letra de los Estatutos de Barcelona, ya que establecía que los novicios debían ser formados en las materias regulares y en canto llano. Después, por riguroso examen, debían demostrar capacidad de ser "choristas", y posteriormente, para obtener el orden sacro deberían tener suficiencia "en la latinidad, y Theologia Moral necesaria; o

37 Robert Stevenson. Music in México: an historical survey. New York: Crowell, [1952], pp. 135, 159.

38 Jesús Estrada, Op. cit., pp. 52-53. 
Complejidad y materialidad: reflexiones del Seminario del ...

así mismo conste de suficiencia de canto llano, y de alguna lengua natural deste reyno". ${ }^{39}$

Por otro lado, conforme la Catedral de México y el clero secular se fortalecieron, su papel en el ámbito musical novohispano ganó presencia. En 1538, las actas del cabildo catedralicio registran el nombramiento del canónigo Juan Juárez "para encargarse del maestrazgo de la capilla musical". Su ocupante tenía la obligación de cantar los domingos y días festivos, junto a los cantores del coro, de componer o interpretar la música y el canto llano y figurado o con órgano para la iglesia, además de impartir educación musical a los cantores, como al público; su elección se basó en las normas que establecía la Catedral de Sevilla, hasta que el Tercer Concilio Provincial estatuyó lo procedente. ${ }^{40}$

El "maestro de capilla era, sin duda, la autoridad en materia de música en Nueva España; a él acudían maestros de capilla de otras catedrales para consultar sobre materias del arte culto. Las obras

39 Franciscanos. Constituciones y leyes municipales de esta Prouincia... México: por la viuda de Bernardo Calderón, 1667, h. 5.

40 Estatutos ordenados por el Santo Concilio III... México: Imprenta de G. Torres, 1859, capítulo XVIII. Del oficio del maestro de capilla y de los cantores, pp. lxxv-lxxvii. 
de los maestros de la catedral de México eran solicitadas por otras catedrales y templos del país". ${ }^{41}$

En cuanto al chantre y sochantre, ellos debían estar instruidos y ser peritos en música y canto llano, su oficio sería el de "cantar en el facistol, y enseñar a cantar a los servidores de la iglesia, y ordenar, corregir, y enmendar por sí y no por otro, las cosas que pertenecen, y miran al canto en el coro". ${ }^{2}$ Bajo esa premisa y con base en los estudios de algunos musicólogos, es claro que desde el siglo XVI hasta el XVIII, ahí trabajaron algunos de los músicos y compositores más destacados en la Nueva España

El Concilio Cuarto Provincial Mexicano (1771) acercó a la iglesia mexicana a la práctica toledana, ya que en sus estatutos señaló que por:

los concilios toledanos está mandado que ningún seglar entre dentro de los canceles del coro para separar las jerarquías, y no perturbar el orden del culto divino; y este mismo decreto renueva este concilio con arreglo a la ley del reino; y exhorta a los obispos y cabildos que los ministros del coro aunque sean músicos, se procure que no estando ordenados, salgan luego de él en acabando las misas, o funciones a que asisten; $y$ desea con ansia que el culto divino, y can-

41 Jesús Estrada Op. cit., p. 53.

42 Estatutos ordenados... Op. cit., capítulo III. La Chantría, p. xxi. 
Complejidad y materialidad: reflexiones del Seminario del ...

to eclesiástico se reduzca a su primer estado, desechando del coro instrumentos del siglo, arias y cánticos que tienen sonido a lo del mundo, sino que todo respire seriedad, y gravedad. ${ }^{43}$

En este Concilio se asumió con más claridad la defensa del canto llano, por sobre el polifónico, y es posible que en ese último cuarto del siglo XVIII, la iglesia mexicana se estuviera replegando ante las nuevas influencias y aires que provenían de Europa.

\section{Los códices corales}

La presencia franciscana en el Continente americano se remonta a la época del descubrimiento del Nuevo Mundo por Cristóbal Colón, en 1492. Cuando el proyecto colombino parecía no tener apoyo de la corona española, la participación de los franciscanos del Monasterio de Santa María de la Rábida, en la Villa y Puerto de Palos, de la Provincia Bética, tuvo un papel crucial en la decisión última de los Reyes Católicos, ya que los frailes Juan Pérez y Antonio Marchena intercedieron ante la reina Isabel la Católica, para que escuchara al genovés. Así, uno de los primeros misioneros franciscanos, embarcado en el segundo viaje de Colón, fue

43 Concilio Provincial Mexicano IV... Op. cit., Libro III, Título 18. "De la celebración de misas y divinos oficios", pp. 156-157. 
precisamente Juan Pérez quien desarrolló la labor de predicación y evangelización de la Orden de los Hermanos Menores, en tierras americanas. ${ }^{44}$

Posterior a ese hecho, desde el año 1523, destaca la presencia de tres frailes flamencos: Johann Dekkens o Juan de Tecto, Johann van der Auwera o Juan de Aora, además de Pieter van der Moere, conocido como Pedro de Gante (c.1486-1572), quien vivió casi cincuenta años en México. ${ }^{45} \mathrm{La}$ labor de este último tendrá una profunda e importante repercusión en las obras que aquí se estudian, ya que él fue el primero en impartir clases a los indios, en el Convento de Texcoco, y fundó la escuela de San José de los Naturales, del Convento Grande de San Francisco, en la ciudad de México, instituto principal de la Provincia del Santo Evangelio, en la Nueva España, donde se confeccionaron algunos de los códices corales novohispanos que conserva la Biblioteca Nacional de México.

Si la primera mitad del siglo XVI fue de oro para los franciscanos en la capital de la Nueva España,

44 Antolín Abad. Los franciscanos en América. Madrid: Mapfre, 1992, pp. [20]-31.

45 Ernesto de la Torre. "El libro belga en México", en Boletín del Instituto de Investigaciones Bibliográficas UNAM, n. 10, julio-diciembre de 1973, p. [9], Edmundo O'Gorman, "Estudio crítico", en Toribio de Benavente, Historia de los indios de la Nueva España. México: Porrúa, 1979, p. 86. 
Complejidad y materialidad: reflexiones del Seminario del ...

no se puede decir lo mismo de las dos centurias siguientes, puesto que la Provincia del Santo Evangelio en particular, y el conjunto de mendicantes y sus fundaciones en general, sufrieron los avatares de la secularización, así como el cambio de reinado de los Habsburgo a los Borbones, en España.

No obstante, el Convento Grande de San Francisco en México resistió esas transformaciones, ya que durante los siglos XVI al XVIII hizo uso de códices litúrgicos para el oficio divino, nombrados en los contratos sevillanos de aquella época como libros de coro $\mathrm{u}$ oficieros. ${ }^{46}$

Cabe advertir que esos códices carecen de la pureza o de la fuerza de un estilo artístico original, es decir, sus formas son híbridas y conjugan elementos plásticos, con "manierismos, barroquismos", y rococó, copiados de grabados y de libros impresos europeos y novohispanos, con notable proyección flamenca, italiana, hispana, alemana y francesa. En especial, la imprenta y tipografía hispalenses, así como los modelos alfabéticos empleados en los libros corales de la Catedral de Sevilla, ejercieron un influjo directo y decisivo en el quehacer bibliográfico y artístico de la Nueva España, durante los siglos XVI al XVIII, pues la importancia política y la

46 María del Carmen Álvarez. El libro manuscrito en Sevilla... Sevilla: Ayuntamiento, 2000, p. 250. 
prosperidad económica que alcanzó Sevilla en ese tiempo tuvo su natural consecuencia en el terreno de las artes, de manera que la ciudad hispalense se transformó durante esos siglos, en uno de los principales centros artísticos de la Península Ibérica que influyeron en América.

En 1524, un año después del arribo de los tres frailes flamencos a la Nueva España, llegaron los "doce apóstoles" o misioneros franciscanos que envió el Papa Alejandro VI, a tierras mexicanas, quienes llevaron a cabo algunas de las obras más notables del primer siglo colonial, esto es, trastocar a una civilización y trasplantar otra.

Desde entonces, los ideales franciscanos encontraron tierra fértil en el Valle de México y la región de la Puebla de los Ángeles. Ese año fundaron la Provincia del Santo Evangelio, en la ciudad de México y al siguiente, los mendicantes iniciaron la construcción del Convento Grande de San Francisco, en el corazón del antiguo imperio mexicano. ${ }^{47}$

A pesar de la ruptura social y cultural que significó la conquista del Nuevo Mundo para los indígenas americanos, con el paso del tiempo se fusionaron y tejieron redes culturales que en la actualidad sería imposible separar. En la Nueva España se in-

47 Jerónimo de Mendieta. Historia eclesiástica indiana. México: CNCA, 1997, v. 2, p. 232. 
Complejidad y materialidad: reflexiones del Seminario del ...

trodujeron concepciones y modelos medievales y renacentistas, que eran ciertamente inéditos para esas tierras, es decir que los conceptos de guerra, religión, arte y escritura no eran semejantes; sin embargo, los cronistas hispanos destacaron la capacidad de aprendizaje y apropiación de los modos culturales europeos, por la parte de los mexicanos.

Uno de los “doce apóstoles”, fray Toribio de Benavente (hacia 1482-1569), llamado Motolinía -que en lengua náhuatl o mexicana significa "Pobre"-, elogió la destreza de un muchacho de Texcoco, quien reprodujo una bula pontificia con tal maestría, "que la letra que hizo parecía el mismo molde [...] y por cosa notable y primera la llevó un español a Castilla. Muchos indios habían aprendido a iluminar, a sacar de planchas imágenes perfectas". ${ }^{48}$

Una versión posterior, la expuso fray Jerónimo de Mendieta (O.F.M.) (1525-1604), quien conoció y leyó la escrita por Motolinía: "No menos habilidad mostraron para las letras los indios [...] Porque luego con mucha brevedad aprendieron a leer, así nuestro romance castellano como el latín, y tirado o letra de mano". ${ }^{49}$ Ambos pasajes hacen referencia a resultados obtenidos poco después de la conquis-

48 Toribio de Benavente. Historia de los indios de la Nueva España.

México: Porrúa, 1979, t. 3, c. 12, p. 169.

49 Jerónimo de Mendieta, Op. cit., v. 2, p. 75. 
ta militar de Hernán Cortés (1521) y de la llegada de los frailes a México.

Entre las tareas franciscanas esenciales destaca la evangelización, sustentada en la predicación y la conversión. En la Nueva España, la catequesis franciscana a los indígenas iba enlazada con la enseñanza del canto llano y la música.

Un punto que interesa subrayar aquí es considerar que tanto en la Iglesia Catedral Metropolitana como en el Convento Grande de San Francisco en México se practicaron operaciones individuales de copia e iluminación de libros, al igual que sucediera en la ciudad de Sevilla, con las que se atendieran las necesidades propias de la institución secular y regular.

Desde que llegaron los franciscanos a la Nueva España, y hasta que se terminó de copiar el último de los libros corales en cuestión, pasó menos de un siglo. Es necesario añadir que la información presenta muchas variables, entre las que se pueden apuntar aquellas que atañen al tránsito y comercio de libros, así como el paso a las Indias de artesanos europeos del libro manuscrito e impreso, quienes desarrollaron sus actividades principalmente en México, la capital del Virreinato de la Nueva España.

Es significativo considerar lo realizado por fray Pedro de Gante, desde 1523, ya que él sentó las bases para crear una schola cantorum de indígenas, así 
Complejidad y materialidad: reflexiones del Seminario del ...

como un conjunto de acciones formadoras de artesanos novohispanos del libro manuscrito.

$\mathrm{Y}$ aunque por su suficiencia pudiera ser del coro, no quiso sino ser lego, por su gran humildad [...] Fr. Pedro de Gante [...] Fue el primero que en esta Nueva España enseñó a leer y escribir, cantar y tañer instrumentos musicales, y la doctrina cristiana, primeramente en Texcoco a algunos hijos de principales, antes que viniesen los doce, y después en México, donde residió casi toda su vida, salvo un poco de tiempo que fue morador en Tlaxcala. En México hizo edificar la suntuosa y solemne capilla de San José a las espaldas de la humilde y pequeña iglesia primera de San Francisco, donde se juntan los indios para oír la palabra de Dios y los oficios divinos. ${ }^{50}$

Gante se dedicó a orientar la enseñanza cristiana de los indígenas con la idea de alabar la obra divina y procuró la formación de los cantores, así como la copia de libros litúrgicos para realizar su objetivo, $\mathrm{y}$ es posible que eso se hiciera en el propio convento, bajo la dirección y mirada del fraile. ${ }^{51}$ En 1532, diez años después de haber llegado a la Nueva Espa-

50 Ibíd., p. 40. Véase "Estatutos de Barcelona", en Francisco de Asís. Regla... "De los legos”. h. 55v.

51 Jerónimo de Mendieta.. Op. cit., v. 2, pp. 311-313. 
ña, fray Pedro de Gante informó al emperador Carlos V de sus actividades educativas:

[...] he tenido y tengo cargo de enseñar los niños $\mathrm{y}$ muchachos a leer $\mathrm{y}$ escribir y puntar y cantar. En todo esto como yo no soy sacerdote, he tenido más tiempo e oportunidad a esta causa y por haber razonable habilidad en la gente, para ello, ha se aprovechado razonablemente y sin mentir puedo decir harto bien que hay buenos escribanos y puntadores [...] y cantores que podrían cantar en la capilla de su majestad. ${ }^{52}$

Ese testimonio apunta a la existencia de una escuela de primeras letras para indígenas, quienes no eran ajenos a ese concepto, ya que antes de la conquista española algunos hijos de los hombres principales se educaban en el sacerdocio indígena, y aprendían a "escribir pintando" los libros sagrados del México antiguo. Me refiero a la escritura pictográfica y jeroglífica de los códices mesoamericanos. ${ }^{53}$

Fray Pedro de Gante recreó esa práctica, aunque con otro sentido, forma y contenido, pues en la escuela que fundó para niños indígenas, en la Capilla de San José, aprendían dos cosas primordiales: a ser

52 Archivo Histórico Nacional, Madrid. Por sus siglas AHN, Sec. Diversos, doc. 22. "Doctrina e instrucción de los indios dada en México por fray Pedro de Gante el 13 de octubre de 1531".

53 Silvia Salgado. Análisis semiótico de la forma arbórea... México: UNAM, 2001, pp. 35-40, [45]-51. 
Complejidad y materialidad: reflexiones del Seminario del ...

cristianos y a tener un oficio. Por un lado, la enseñanza de la doctrina, las letras, el canto y la música; y por otro, el aprendizaje de un quehacer útil, como el de zapatero, cantero, herrero, carpintero, tallador, escribano, dibujante, pintor, o grabador, que los indígenas mexicanos aprendieron de copiar estampas sueltas o de impresos europeos.

Con Gante se gestó una de las actividades más espléndidas de la primera misión franciscana en la Nueva España: la de formar gente en la cultura y el arte del libro, de la pintura y de la música de Europa. ${ }^{54}$ Sin embargo, en los primeros tiempos de la conquista y de la colonización hispana, la mayoría de los libros manuscritos e impresos que se conservan fueron llevados a México por soldados, civiles y religiosos europeos. ${ }^{55}$

Por real cédula se extendió un permiso para introducir libros litúrgicos a las Indias, emitida por Carlos V, el 25 de octubre de 1538, donde estableció lo siguiente: "Real cédula a los oficiales reales de la Nueva España para que no lleven derechos de almojarifazgo a Antón Gómez, clérigo, de los orna-

54 Toribio de Benavente. Op. cit., p. 169. Jerónimo de Mendieta. Op. cit., v. 2, pp. 70, 75-77.

55 Para los libros de caballería, véase I. Leonard. Los libros del conquistador. México: FCE, 1979. En el caso de los inventarios y bienes de difuntos de los pasajeros a Indias, véase C. González. Los mundos del libro... Sevilla: Universidad de Sevilla, 2001. 
mentos, libros de canto y otras cosas que lleva para la iglesia catedral por encargo del obispo de México. Emitida en Toledo". ${ }^{56}$ En dicha cédula se advierte que fray Juan de Zumárraga (O.F.M.), primer obispo de México, solicitó libros de coro para atender las necesidades litúrgicas de su catedral; pero la carta no informa de la naturaleza impresa o manuscrita de las obras que pasarían a la Nueva España.

Uno de los documentos más interesante, relativo a la travesía de un clérigo y artesano europeo del libro, a México, fue emitido el año 1538, y se refiere a la licencia otorgada por Carlos V a Juan de Aveci1la, presbítero, vecino de Sevilla y "buen escriuano de letra formada para libros de iglesia y canto", a petición del obispo y del cabildo catedralicio de México, con la intención de que trabajara para la Catedral de México. ${ }^{57}$

En ese año, la imprenta no había llegado a México y por lo mismo se necesitaban libros y artesanos europeos; además, hay que considerar que en ese tiempo, la Iglesia mexicana era sufragánea de la Ca-

56 Archivo General de Indias, Sevilla. Por sus siglas AGI. México, 1088, Libro 3, f. 210 /25-10-1538/ Real cédula.

57 AGI. Indiferente, 1962, Libro 6, ff. 38v y 144v /22-11-1538/ Real cédula. Citado por María del Carmen Álvarez. Op. cit., pp. 23, 51, 102, 129. 
Complejidad y materialidad: reflexiones del Seminario del ...

tedral de Sevilla, y por lo mismo, los libros litúrgicos tenían el sello hispalense.

No abundan las noticias sobre frailes escritores de libros litúrgicos e iluminadores en la Nueva España; sin embargo, de la formación de los artesanos americanos del libro, desarrollada por los franciscanos de la Provincia del Santo Evangelio, especialmente en el Convento Grande de México y en el Colegio de Santiago de Tlatelolco, fray Jerónimo de Mendieta dejó el siguiente testimonio:

Después se fueron haciendo muy grandes escribanos de todas letras, chicas y grandes, quebradas y góticas. Y los religiosos les ayudaron harto a salir escribanos, porque los ocupaban a la continua en escribir libros y tratados que componían o trasuntaban de latín o romance en sus lenguas de ellos. Yo llevé el año de setenta (que fui a España) un libro del Contemptus mundi, vuelto en lengua mexicana, escrito de letra de indio, tan bien formada, igual y graciosa, que de ningún molde pudiera dar más contento a la vista. Y mostrándola al licenciado D. Juan de Ovando, que a la sazón era presidente en el Consejo de Indias, agradóle tanto, que se quedó con él, diciendo que lo quería dar al rey D. Felipe nuestro señor. ${ }^{58}$

58 Jerónimo de Mendieta. Op. cit., v. 2, p. 75. 
A fray Pedro de Gante lo siguieron otros religiosos en la tarea de hacer una escuela de escritores y copistas que alimentara las intensas labores de evangelización. La acción de escribir las doctrinas, los vocabularios, manuales o confesionarios en latín, en castellano y en mexicano requirió de la preparación de equipos de trabajo plurilingüe. Pero no sólo escribían obras para la evangelización, también hacían libros propios de la liturgia:

Demás del escribir, comenzaron luego los indios a pautar y a puntar, así canto llano como canto de órgano, y de ambos cantos hicieron gentiles libros y salterios de letra gruesa para los coros de los frailes, y para sus coros de ellos con sus letras grandes muy iluminadas. Y no iban a buscar quién se los encuadernase, porque ellos juntamente lo aprendieron todo. ${ }^{59}$

En este testimonio quedó dicho que los indios hacían libros de coro, por lo que seguramente copiaban los modelos manuscritos o impresos que traían o encargaban los misioneros europeos. De hecho, la Biblioteca Nacional de México conserva breviarios impresos, con la marca de fuego del Convento Grande de San Francisco de México, así como con el ex libris Ex Bibliotheca Magni Mexicani

59 Ibíd. 
Complejidad y materialidad: reflexiones del Seminario del ...

Conbentus S.P.N.S. Francisci. Eso significa, que tenían los modelos gráficos, principalmente flamencos, italianos, franceses, alemanes e hispanos, para recrearlos en la superficie pintada de los códices realizados en el Convento Grande de San Francisco de México.

Los estudios de Toussaint, Romero de Terreros y Tovar, que se refieren a la familia Lagarto, como los iluminadores de algunos de los más bellos libros corales de las catedrales de las ciudades de México y de Puebla, hacia el final del siglo XVI y principio del XVII, son tres de los trabajos más importantes que han tratado el tema, desde la óptica de la Historia del Arte. ${ }^{60}$

Sin tener evidencia a la vista, G. Tovar ha propuesto dos fechas posibles para la llegada de Luis Lagarto a la Nueva España: 1579 o 1585. Primero señala que "Podría pensarse que el iluminador llegó a la Nueva España en el séquito del obispo Romano en 1579; sin embargo no aparece en el Catálogo de Pasajeros de Indias y carecemos de testimonios que así lo demuestren”. Más adelante dice que si las no-

60 Manuel Toussaint. Pintura colonial en México. México: UNAM, 1990. Manuel Romero de Terreros. Grabados y grabadores en la Nueva España. México: Ediciones Arte Mexicano, 1948, pp. 65-69, Guillermo Tovar. Un rescate de la fantasía...México: El Equilibrista, Madrid: Turner, 1988. 
ticias firmes sobre Luis Lagarto en México, son del año 1586, entonces la fecha de su llegada "es muy probable que fuese en 1585 ". ${ }^{61}$

La hipótesis de Tovar es que Luis Lagarto nació en Sevilla el año 1556 y que siendo niño pasó a Granada, donde se formó con Lázaro de Velasco, hijo de Jacobo Florentino, quien fuera amigo de Miguel Ángel y condiscípulo del Pinturicchio, en el taller de Ghirlandaio. Además, el posible maestro de Luis Lagarto, fue iluminador de los libros corales de la Catedral de Granada, de 1550 a 1583, "lo cual -dice Tovar con respecto a Luis Lagarto- explica su formación italianizante".

La primera obra que se conserva de Luis Lagarto, en la Nueva España, es un libro de coro iluminado para la Catedral de México, realizado entre 1586 y 1595. Debieron haber más libros iluminados suyos, puesto que fue contratado para ello, pero no se localizan en aquel templo. Para el año 1600 salió a la ciudad de Puebla de los Ángeles, requerido por el obispo Romano -canónigo de la Catedral de Granada en el tiempo de Lázaro de Velasco-, y trabajó en la factura de las letras magníficamente iluminadas de un centenar de cantorales para la Catedral de Puebla, de 1600 a 1611. Regresó a México el año de

61 Guillermo Tovar. Op. cit, pp. 21, 26. 
Complejidad y materialidad: reflexiones del Seminario del ...

1612 y, según Tovar, las obras que firmó y fechó van de 1609 a $1619 .{ }^{62}$

El estilo mostrado en los corales de 1603, 1606 y 1616, no presenta la maestría y originalidad que Luis Lagarto ostentó en sus iluminaciones. Parece más probable hablar de la influencia del estilo de Lagarto que generó seguidores, como Lucas García, quien desde 1601 hasta 1603 fue contratado por el canónigo Francisco de Paz, para iluminar los libros de coro de la Catedral de México. ${ }^{63}$

Otro de los artesanos europeos que iluminó libros para la Catedral de México fue Diego de Zamora, vecino de Sevilla y pintor de imaginería, ${ }^{64}$ que en el año 1595 entregó veintiséis libros de canto con destino a aquella Iglesia, al escritor de libros e iluminador Melchor Riquelme, quien se los había encargado. ${ }^{65}$

No existen noticias de los trabajos de Lagarto de 1595 a 1600, pero sí del pedido para la confección de libros corales a Melchor Riquelme, "maestro de la librería de la Iglesia Catedral de Sevilla”, quien a

62 Ibíd., pp. 14, 25-26, 27.

63 Ibid., pp. 69, 225-227.

64 José Gestoso. Op.cit. v. 3, p. 420.

65 María del Carmen Álvarez. Op. cit., pp. 68, 243. El documento que testifica el pago y entrega del trabajo al clérigo Alonso Ruiz se conserva en el Archivo Histórico de Protocolos de Sevilla, Legajo 108, f. 383. 
su vez contrató a un pintor como iluminador, para poder abastecer la demanda de la iglesia mexicana. Ésta es la segunda noticia de libros de coro encargados y realizados por un escritor e iluminador de la catedral hispalense; pues recordemos que la primera es del año 1538 relativa a Juan de Avecilla. Si los libros llegaron a México, seguramente el estilo de la escritura de Riquelme y de las iluminaciones de $\mathrm{Za}$ mora fueron conocidos y posiblemente recreados por los artífices novohispanos. Así, cinco años antes de que concluyera el siglo XVI, las únicas noticias que se tienen de artesanos europeos del libro, contratados como copistas e iluminadores, son de aquellos sevillanos que trabajaron para la Catedral de México.

En cuanto a la orden franciscana, la primera noticia que se tiene es del año 1602, y se trata de un fraile menor de la Provincia de Andalucía, llamado Juan de la Mota.

\section{Manuscritos e impresos}

De Sevilla salió la primera imprenta a la Nueva España, solicitada al emperador Carlos V, por el obispo Juan de Zumárraga y por Antonio de Mendoza, virrey de México. Juan Cromberger, hijo de Jacobo, el alemán que estableció su empresa tipográfica en Sevilla el año 1502, fue quien envió la primera imprenta a la Nueva España, a cargo de su so- 
Complejidad y materialidad: reflexiones del Seminario del ...

cio y operario Juan Pablos, impresor italiano, el año de 1539. En la primera etapa de la empresa novohispana, Juan Pablos imprimía y además vendía los libros salidos de las prensas sevillanas de los Cromberger. ${ }^{66}$

Durante el primer siglo del Virreinato de la Nueva España se imprimieron cerca de doscientos cincuenta títulos, en su mayoría dedicados a la evangelización, y entre ellos destacan los autores franciscanos, a quienes se les atribuyen cuarenta y siete libros. ${ }^{67}$ En cuanto a los siete u ocho impresores que se afincaron en la ciudad de México durante aquel siglo, su procedencia era italiana, española, francesa, flamenca y finalmente criolla.

El trabajo más fino y al parecer uno de los más destacados fue el de Antonio de Espinosa, vecino de la ciudad de Sevilla y segundo impresor en la Nueva España. Llegó a México hacia 1550, contratado como fundidor de tipos, por Juan Pablos, quien ya había comprado la empresa novohispana a los Cromberger. ${ }^{68}$

66 Clive Griffin. Los Cromberger... Madrid: Instituto de Cooperación Hispana..., 1991. Jesús Yhmoff. Los impresos novobispanos... México: UNAM, 1990, p. [9]

67 Ramón Zulaica. Los franciscanos y la imprenta en México en el siglo XVI. México: Pedro Robredo, 1939.

68 Alexandre Stols. Antonio de Espinosa... México: UNAM, 1990. 
Esa imprenta trabajó principalmente para el virrey, el cabildo catedralicio y las órdenes mendicantes y mantuvo el monopolio durante veinte años, hasta que en 1559, el andaluz Antonio de Espinosa, mediante la intervención del emperador, rompió tal control. En los primeros años de la imprenta novohispana, las letras góticas empleadas por Juan $\mathrm{Pa}$ blos, habían sido llevadas por él o enviadas por los Cromberger. Pero cuando llegó Antonio de Espinosa, como fundidor y cortador de tipos, este introdujo un estilo moderno y exquisito en los módulos alfabéticos, así como en los grabados, lo que significó una "superación del estilo tipográfico de los libros impresos en el taller de Pablos". ${ }^{69}$

Paralela a la imprenta, fray Pedro de Gante continuó con su labor educativa. Uno de sus discípulos, en el arte del dibujo y del grabado fue fray Diego Valadés, ${ }^{70}$ (O.F.M.) (Tlaxcala 1533-¿?). No se sabe si era criollo o mestizo, pues fue hijo del conquistador español Diego Valadés; pero de su madre sólo se elucubra que era una india tlaxcalteca, asunto muy delicado puesto que ese origen podía dificultar e incluso impedir su ingreso a la orden franciscana.

69 Ibíd., p. 7.

70 Esteban Palomera. "Introducción”, en Diego de Valadés. Retórica cristiana. México: UNAM, FCE, 1989, p. viii-ix 
Complejidad y materialidad: reflexiones del Seminario del ...

Autor de la Rhetorica Christiana, primera obra escrita en latín, ilustrada de su mano y publicada en Europa por un novohispano (Perugia, 1579), Valadés se integró a la escuela de San José siendo niño y ahí aprendió "el arte de la pintura y del dibujo, en lo que llegó él mismo a ser maestro de ese plantel" ${ }^{71}$ Gante y Valadés convivieron de 1543 a 1553 en el Convento de San Francisco, primero como maestro y alumno, después Valadés fue su secretario, y finalmente como colegas.

Fray Jerónimo de Mendieta no lo mencionó en su Historia eclesiástica indiana, pero sí recreó cuatro láminas que realizó y publicó Valadés en su $R e$ tórica. Lo mismo hizo fray Juan de Torquemada, en la portada de su Monarquía Indiana (Madrid, 1615). ${ }^{72}$ Por otra parte, Valadés fue colegial de Jean Focher (O.F.M.), seguidor de Duns Scoto y doctor de la Universidad de París, quién decía que los pobres estaban más cerca de la perfección cristiana.

Valadés fue su discípulo en el Colegio de Santiago de Tlatelolco, en México, y tiempo después llevó a Sevilla el manuscrito de Focher titulado el Itinerarium Catholicum, donde lo imprimió Alfonsum Scribanum, en 1574. En el prólogo, Valadés dejó constancia de su colaboración en esa obra.

71 Ibid.p. ix

72 Ibid.,p. xviii 
El Itinerarium Catholicum es el primer tratado misional sobre América conocido hasta el presente. Es también el manual de que, a partir de su aparición, se valieron los misioneros, sobre todo los de Nueva España, para solucionar los múltiples e intricados problemas que planteaba el nacimiento de la nueva Iglesia de Indias. ${ }^{73}$

En 1575, fray Diego Valadés fue nombrado procurador general de la Orden, durante el Capítulo de Roma, pero dos años después tuvo que dejar el cargo por intervención expresa de Felipe II, quien lo acusó de abuso de autoridad. Al dejar el puesto, se dedicó a escribir e ilustrar su obra con veintisiete grabados en cobre, entre los que incluyó dos alfabetos, uno de ellos era obra de Ludovico Dolce, amigo de Ticiano. Además dibujó las iniciales en las que quedó reflejada su formación humanista. ${ }^{74}$ Este es el caso más documentado de un novohispano educado en el sistema franciscano, iniciado por fray Pedro de Gante, que aprendió y enseñó la liturgia romana, así como el arte de escribir pintando.

Durante los veintiún años que vivió el impresor Juan Pablos en México, no cubrió la demanda no-

73 Antonio Eguiluz. "Prólogo", p. [viii], en Jean Focher. Itinerario del misionero en América. Madrid: Librería General Vitoriano Suárez, 1960.

74 Esteban Palomera, "Introducción”, p. xv, Op. cit. 
Complejidad y materialidad: reflexiones del Seminario del ...

vohispana de obras litúrgicas y el comercio de libros aumentó incesantemente. Antonio de Espinosa fue el segundo impresor en la Nueva España, que aportó un repertorio refinado de letras y grabados a sus libros. Imprimió varias obras de evangelización de autores franciscanos, entre los que sobresale fray Alonso de Molina con sus Confesionarios y Vocabulario (en mexicano y castellano); pero también imprimió libros de canto litúrgico y en ese punto destacan dos Graduales dominicales, impresos hacia 1568 y en 1576 respectivamente, ya que en ellos se encuentran la mayoría de los modelos alfabéticos empleados posteriormente en las obras que aquí se estudian. Esos son los primeros libros de canto impresos en la Nueva España, y significa que Espinosa conocía la técnica de impresión del pautado y las notas, desarrollada desde el siglo XV. ${ }^{75}$

Por otra parte, también en el año de 1559 se otorgó a Alonso Pérez, de la Diócesis de Medina del Campo, un permiso por diez años para imprimir libros de canto en la Indias: "Real cédula concedida a Alonso Pérez, clérigo presbítero, beneficiado en Rodilana, el derecho exclusivo por término de diez años, para imprimir en pergamino y vender en Indias libros de canto, previa tasación de su precio

75 María del Carmen Álvarez. Op.cit., p. 101. 
en el Consejo de Indias. Emitida en Valladolid" ${ }^{76}$ El asunto de la impresión y venta parece ser que no prosperó, pero habría que destacar el hecho de que la real cédula establecía como soporte de la impresión el uso de pergamino, material poco empleado para esos menesteres, después de la invención de la imprenta. Desde Johannes Gutenberg, quien imprimió en pergamino algunos de los ejemplares de la Biblia de cuarenta y dos líneas, la proporción fue mayor para el papel. Es posible que al tratarse de libros de canto para el oficio divino se mandarían a hacer en pergamino, además que Alonso Pérez, "scriptor de libros", fue quien propuso el pergamino para la impresión. ${ }^{77}$ Es difícil imaginar el éxito de la empresa por las cantidades requeridas y las dificultades para obtener el preciado material; no obstante, a la mitad del siglo XVI, el monarca ordenó que se usara pergamino como soporte para los libros litúrgicos impresos que se enviarían a las Indias, cuando lo común era el papel.

El año 1573, Felipe II otorgó en exclusiva a la imprenta escurialense la facultad de dotar a las Indias de las obras litúrgicas: "Real provisión concedida al monasterio de San Lorenzo del Escorial licencia de

76 AGI. Indiferente, 425. L. 23, ff. 403v-404r /17-06-1559 / Real cédula.

77 AGI. Justicia, 1165, N. 4, R. 1, imágenes 5-6. Ibíd. 
Complejidad y materialidad: reflexiones del Seminario del ...

privilegio de imprimir y vender en Indias misales, breviarios, libros de horas y del oficio divino, con exclusividad. Lugar de emisión: El Pardo". ${ }^{78}$ Pero esa provisión no fue respetada en la Nueva España, pues Antonio de Espinosa y Pedro Ocharte, dos de los impresores avecindados en México, publicaron un Graduale dominicale en 1576 y una Psalmodia christiana en 1583, respectivamente. ${ }^{79}$

Hacia 1597, la imprenta novohispana se hallaba en su cuarta generación, con los herederos de Pedro Ocharte, tercer impresor en la Nueva España, quienes instalaron su imprenta en el convento franciscano de Santiago Tlatelolco, conocido como Imperial y Real Colegio de Indios de Santa Cruz. Ahí se encontraba también, "como reo del Santo Oficio de la Inquisición, el impresor holandés Cornelio Adriano César, cuyo taller había sido confiscado" ${ }^{80}$ Natural de Haarlem, fue oficial del impresor flamenco Christophe Plantin, en la ciudad de Leyden y "pasó a México a fines del siglo XVI, donde

78 AGI. Indiferente, 426. L. 25, F. 270r-271v. / 01-12-1573 / Real provisión.

79 Alexandre Stols. Op. cit.

80 Ibid., p. 26. 
prestó sus servicios en varias imprentas. Murió hacia 1633". ${ }^{11}$

De la imprenta de los Ocharte salió un folio con el calendario para el uso de los frailes menores, del año 1598, en el que consta que trabajó Cornelio Adriano César. También imprimieron un libro con la iconografía franciscana de los estigmas, que se observa en la inicial $C$ del segundo oficio en cuestión. En el ámbito tipográfico del siglo XVI, no hay noticias de indios ni de mestizos (hijos de indias y españoles) en las imprentas novohispanas, pero Motolinía y Mendieta -que entonces redactaba su Historia-, informaron que los indios grababan "imágenes de planchas de bien perfectas figuras, tanto que se maravillan cuantos las ven, porque de la primera vez la hacen perfecta". ${ }^{82}$

Hay que recordar que ambos habitaron en el Convento de San Francisco de México, además que Mendieta fue contemporáneo del libro de coro más antiguo que aquí se estudia y su testimonio es fundamental, ya que consagró buena parte de su vida a escribir la crónica de la Orden en la Provincia del

81 Juan B. Iguíniz "Poliantea bibliográfica II", p. 21, en Boletín de la Biblioteca Nacional de México, $2^{2}$ época, t. 6, n. 2, abril-junio de 1955.

82 Toribio de Benavente. Op.cit., p. 169. Jerónimo de Mendieta. Op.cit., v. 2, p. 75. 
Complejidad y materialidad: reflexiones del Seminario del ...

Santo Evangelio. El libro V de su obra -que empezó a formar desde 1574- constituyó el apartado que correspondió a esa Provincia, en De Origine, la historia franciscana compilada por fray Francisco de Gonzaga.

En 1596 Mendieta comenzó a redactar la Historia eclesiástica indiana, y a su muerte, fray Juan de Torquemada (O.F.M.), fue solicitado para publicarla; sin embargo, en ese tiempo, fue también invitado a escribir la historia franciscana en la Nueva España, sin embargo antes que imprimir el manuscrito de Mendieta, prefirió adoptar y adaptar partes de la Historia Eclesiástica Indiana para su Monarquía Indiana (Madrid, 1615). ${ }^{83}$ Sin embargo, como historiador de la Orden, Torquemada fue el primer biógrafo de Mendieta, a quien perfiló de la siguiente forma: "pintaba en algunas partes todos los Misterios de nuestra Redempción para que los indios mejor lo entendieren y otras muchas cosas de las Sagradas Escrituras del Testamento Viejo, porque era religioso mui ocupado. Y cuando no tenía que hacer (después de los ratos de oración y devoción)

83 En 1860 el manuscrito de Mendieta se encontraba en Madrid y el bibliógrafo mexicano Joaquín García Icazbalceta lo mandó comprar y a sus expensas se publicó por primera vez en 1870. Actualmente el original se encuentra en la Biblioteca de la Universidad de Texas, en Austin. 
se ocupaba en rotular los libros de la librería y convento [...] jamás dejaba de seguir el coro a todas las horas hasta que ya fue muy viejo y cayó en la última enfermedad de la cual murió". 84

Si atendemos a la cita de Torquemada, inferimos que Mendieta era uno de los bibliotecarios de la librería del Convento de San Francisco y que al tener acceso directo a los libros y a los documentos del Archivo franciscano -que en parte se conserva en la Biblioteca Nacional de México-, pudo escribir la historia de la Orden, en esa Provincia.

Por sus labores bibliográficas, es posible que Mendienta supiera del origen y factura de los libros manuscritos e impresos de esa biblioteca. La fecha de su deceso, sucedió un año después de que se concluyera el más antiguo de los libros de coro (1603) que conserva la Biblioteca Nacional de México, el cual contiene los oficios de San Francisco, ocurrido en el Convento Grande de la ciudad de México, por lo que su testimonio es de primera fuente y en él se reseñó la formación de los indígenas como artesanos americanos del libro, es decir, como copistas e iluminadores, dibujantes y grabadores, así como encuadernadores. También registró el empleo y

84 Juan de Torquemada. Monarquía indiana. Introd. Miguel León Portilla. México: FCE, 1963, v. 3, libro xx, capítulo lxxiii, pp. 562-563. 
Complejidad y materialidad: reflexiones del Seminario del ...

provecho de esas habilidades por los frailes, para que pautaran, puntaran, escribieran, pintaran e iluminaran libros de coro, y el sitio apropiado para esas tareas fue el Convento de San Francisco, posiblemente en la propia librería. Mendieta no se refirió a los frailes, de manera directa, como copistas o iluminadores de libros, pero sí señaló que enseñaban a los indios en esas artes, por lo que ellos mismos pudieron ser maestros y artífices de la confección y copia de los libros litúrgicos.

Al final del siglo XVII, fray Agustín de Vetancurt (O.F.M.), (1620-1700), cronista y nahuatlato novohispano escribió un Teatro mexicano ${ }^{85}$ en donde reseñó la historia de la orden franciscana durante los siglos XVI y XVII. Ahí se encuentra información sobre el sitio que ocupó la valiosa librería del Convento Grande de México. En su detallada descripción no hizo mención de un escritorio donde se realizara la confección de libros manuscritos, pero sí apuntó que continuaba la enseñanza a los indígenas de la lectura y la escritura por un maestro de cantores, además que ahí también estaba una de las tres casas de estudio de teología, artes y gramática, que los franciscanos tenían en la Nueva España,

85 Agustín de Vetancurt. Teatro mexicano... México: por doña María de Benavides, 1698. 
factor que obligaba al uso de libros impresos y manuscritos. ${ }^{86}$

\section{Códices corales sevillanos en México}

La catalogación de los libros de coro de la Biblioteca Nacional de México, de la Iglesia Catedral Metropolitana, así como el primer acercamiento a la colección del Museo Nacional del Virreinato ha permitido identificar artesanos y artistas del libro que participaron en su elaboración. Destaca la presencia de copistas e iluminadores andaluces tales como Luis Lagarto, Melchor Riquelme, Diego de Zamora y Juan de la Mota.

De los copistas que trabajaron para la Catedral de México, el antecedente más remoto corresponde al clérigo presbítero Juan de Avecilla, vecino de Sevilla, quien fue requerido en 1538 por el obispo Juan de Zumárraga, al emperador Carlos V, para que pasara a la Nueva España. ${ }^{87}$ En el Libro 1 de las actas del Cabildo catedralicio se tienen los registros de su presencia en México, de 1540 a 1544. El primer testimonio es el siguiente: "Primeramente se

86 Ibíd., pp. 20, 37, 84-85.

87 Archivo General de Indias, en adelante: AGI. Indiferente 1962, Lib. 6, f. 1440, fotograma 298. Toledo 1538/nov/22. Citado por María del Carmen Âlvarez. Op. cit., p. 129. 
Complejidad y materialidad: reflexiones del Seminario del ...

concertó su señoría y los señores de cabildo al padre Avecilla sobre escribir el salterio para esta dicha iglesia en esta manera: que el dicho padre Avecilla ha de escribir el dicho salterio de una letra grande de que dio por muestra en el dicho cabildo que dice Ave María" 88

Medio siglo después se tienen datos de que el iluminador Luis Lagarto era pintor y vecino de la ciudad de México, y que trabajó para la Catedral metropolitana. A él se atribuye un himnario que se conserva en la colección mexicana y que podría considerarse como el más antiguo de su vasta producción. ${ }^{89}$

Poco antes de que Luis Lagarto emigrara a la Catedral de la Puebla de los Ángeles, en el Libro 4 de las actas del Cabildo de la Catedral, con fecha 5 de septiembre de 1595, se registró el pago que se otorgó por el encargo de 26 cantorales confeccionados en España y que a la letra dice: "Este día se mandó dar libranza por cuenta de los cuatro novenos, en el canónigo Francisco de Paz, de tres mil y doce pesos, dos tomines y diez granos, que pareció haber

88 Archivo del Cabildo Catedralicio Metropolitano de México, Actas de Cabildo, en adelante: ACCM, AC 1. f. 31v: 1540/jul/ 16. Véase también ACCM. AC 1, f. 60: 1544/ene/15.

89 G. Tovar: Un rescate de la fantasía..., México: El Equilibrista, Madrid: Turner, 1988, pp. 66-68. 
costado y pagado el dicho canónigo, por veintiséis cuerpos de libros grandes para servicio del coro, que por orden de esta congregación se trajeron de España". ${ }^{90}$

Por el otro lado de la Mar Océano, esta noticia tiene su correspondencia directa con el testimonio documental fechado el 28 de septiembre de 1595, que se conserva en el Archivo Histórico Provincial de Sevilla, en el que se estipula que Melchor Riquelme, maestro de la librería de la Catedral de Sevilla, pagó 3000 reales a Diego de Zamora, pintor de imaginería por: "cuanto por su orden y traza iluminó todas las letras grandes con historias con más de 400 letras pequeñas prolongadas de 26 cuerpos de libros de canto que tuvo a su cargo de hacer e hizo y por orden y traza se hicieron para la Santa Iglesia de México de la Nueva España".

Ambos testimonios -el sevillano y el mexicanocoinciden en las fechas, en el origen hispano de los libros, en el número y destino de los volúmenes, además de estar iluminados con letras grandes historiadas. Gracias a la catalogación de la colección

90 ACCMM, AC 4, f. 133: 1595/sep/05.

91 Archivo Histórico Provincial de Sevilla, en adelante: AHPS, Leg. 198, f. 383: 1595/sep/28. Comentado y citado por María del Carmen Álvarez. Op. cit., p. 243. Citado también por José Gestoso. Op. cit., v. 3, p. 420. 
Complejidad y materialidad: reflexiones del Seminario del ...

de cantorales de la Catedral de México se han identificado 14 libros de misas vinculados a las anteriores noticias, ya que ostentan letras capitales iluminadas con historias del Nuevo Testamento bajo el mismo estilo artístico. Asimismo, como supone Carmen Álvarez, Melchor Riquelme pudo ser el encargado de la escritura de los 26 libros de canto. ${ }^{92}$

En dos de los libros de misas se inscribieron los años de 1593 y 1594, fechas anteriores a la de la carta de finiquito de Diego de Zamora y a la libranza que otorgó el Cabildo catedralicio por la confección de los 26 cuerpos de libros, lo que permite suponer que las 14 misas son parte de los libros de coro sevillanos que se encargaron, copiaron, iluminaron, atravesaron el Atlántico, llegaron a la Nueva España y se conservan en la colección coral de la Catedral de México.

Por otra parte, fray Juan de la Mota copió al menos seis cantorales, en el Convento Grande de San Francisco en Sevilla. Dos de ellos se localizan en la Biblioteca Nacional de México y cuatro más están en el Museo Nacional del Virreinato, en Tepotzotlán. Sus fechas de creación se enmarcan entre 1602 y 1615 . Todos son semejantes en la forma caligráfica, pero no así en la representación artística, por lo

92 María del Carmen Álvarez. Op. cit., p. 95. 
que es de suponer que hubo un copista, pero más de un iluminador. Cabe destacar que los libros de la Biblioteca Nacional han sido catalogados y estudiados de manera más amplia y profunda que aquellos conservados en el Museo Nacional del Virreinato.

Los primeros dos libros que se describen en este apartado, se localizan en la Biblioteca Nacional de México, con la signatura topográfica RMS 782.3F IGL.2 y ostentan el siguiente colofón: "Este libro escribio F. Juan de la Mota. Año de 1606”. A lo largo de la obra se aprecia una caligrafía gótica rotunda muy cuidada y limpia, basada en los modelos de Juan de Icíar. ${ }^{93} \mathrm{El}$ gran volumen contiene tres semanas de celebraciones que se realizan en los meses de marzo y abril, con veinte misas consecutivas, desde el tercer domingo de Cuaresma, la semana del Domingo de Ramos (In die Palmarum), hasta el sábado posterior a la Pasión. Los textos son fieles al Misal romano tridentino por lo que todas las fiestas tienen una estructura regular. El trabajo de los iluminadores es anónimo y eso significa que sus autores no buscaron ser reconocidos como artistas, en el sentido renacentista o barroco del término, sino

93 Juan de Icíar. Arte sutilísima, por la cual se enseña a escribir perfectamente: hecho y experimentado y ahora de nuevo añadido... año 1553. [Valladolid]: Junta de Castilla y León, Consejería de Educación y Cultura, 2002. 
Complejidad y materialidad: reflexiones del Seminario del ...

que hicieron sus obras conforme al concepto del artesano medieval que se consideraba un instrumento de Dios, más que un creador.

El segundo cantoral porta la clasificación RMS 782.3F IGL.9, y contiene dieciséis misas del tiempo común de los santos. El libro no está fechado y se desconoce su procedencia, pero en la inicial $B$ quebrada del folio $73 \mathrm{v}$ tiene inscrito el nombre de fray Juan de la Mota, en letra cursiva, por lo que se puede suponer que se realizó también en Sevilla, durante el primer cuarto del siglo XVII. La misa inaugural está dedicada a los apóstoles san Pedro y san Pablo, luego, las siguientes nueve corresponden a distintos mártires.

El Museo Nacional del Virreinato conserva obras fundamentales del arte colonial mexicano, resguarda ochenta y seis libros de coro de la Iglesia catedral metropolitana, así como de algunos conventos novohispanos. Anteriormente, esa colección se encontraba en la Biblioteca Nacional de Antropología e Historia, pero en la década de 1980 pasó en comodato al Museo Nacional del Virreinato. En 1967, Thomas Stanford los catalogó en el repositorio bibliográfico y apuntó una signatura que ya no conservan, pues ahora se les localiza con un número de inventario. Sin embargo, en ese universo libresco se identificaron cuatro cantorales con el nombre del fraile amanuense Juan de la Mota, el 
mismo que copió los de la Biblioteca Nacional de México. La importancia de este hallazgo reside en que ahora se sabe que esos libros se escribieron por el mismo fraile, en el Convento Grande de San Francisco de Sevilla, ya que esto último se registró en uno de los cantorales del Museo.

A continuación se hace referencia a lo inscrito al final de los cuatro volúmenes de Tepotzotlán:

En el colofón del cantoral BNAH Antif XXVIII (10-136878) se apuntó la clave que aclara el origen sevillano de los libros: "Este Psalterio que contiene feria quarta y quinta lo escribio en el Conv[en]to Casa Grande de la Provincia de Andalucia, el $\mathrm{R}$ [everend]o P. F. Juan de la Mota: y lo acabo año de 1602". Cabe aclarar que la sede de dicha provincia está en la ciudad de Sevilla (Castillo 1988), y que este es el libro más antiguo de los seis que se han encontrado.

El segundo libro porta la signatura BNAH Ant XXI, (10-136840) y en su anotación final tiene lo siguiente: "Este libro escribio, El Padre Fr[ay] Jhoan de la Mota Año de 1615”.

En el remate del tercer cantoral, con la clasificación BNAH Antif XXII, se lee "Escribiolo, Fra Juan de la Mota, frayle menor".

Por último, en el colofón del libro BNAH Antif XXXI (10-136834) se anotó "Este libro escribio El Padre, Fray Johan de la Mota. Año de 1615”. 
Complejidad y materialidad: reflexiones del Seminario del ...

Hay entonces un copista que firmó seis cantorales entre los años 1602 y 1615, pero no así los seis o siete iluminadores que ornamentaron dichos libros. Está por hacerse el estudio de la forma y la función de las iluminaciones de los volúmenes del Museo Nacional del Virreinato, pero después de haber hecho la primera lectura visual de dichas obras, se puede advertir más habilidad y maestría en los iluminadores de los dos libros de la Biblioteca Nacional de México.

\section{Reflexión final}

Con el hallazgo de los 20 cantorales sevillanos llegados a la Nueva España se constata la persistencia del arte de la iluminación de manuscritos en la Vieja España, durante una época más propicia para los impresos y grabados. No obstante, dichas manifestaciones encontraron tierra fértil en México y se siguieron practicando aún hasta el ocaso del siglo XIX. Finalmente, tres recintos mexicanos conservan dicho patrimonio tangible en el que están presentes las huellas del trasiego atlántico de la cultura escrita. 
Códices corales sevillanos en México

\section{Bibliografía}

Ayarre, José E.; González. Herminio; Vázquez, Mario. Archivo Musical de la S. I. Catedral de Sevilla. Sevilla: [impresión], 1995.

Abad, Antolín. Los franciscanos en América. Madrid: Mapfre, 1992.

Álvarez, María del Carmen. El mundo del libro en la catedral de Sevilla: siglo XVI. Sevilla: Universidad de Sevilla, 1992.

--. El libro manuscrito en Sevilla. Siglo XVI. Sevilla: Ayuntamiento, 2000.

Benavente, Toribio de. Historia de los indios de la Nueva España. Estudio crítico de Edmundo O'Gorman. México: Porrúa, 1979.

Camacho, Rafael S. Disertación sobre la importancia del canto gregoriano. Guadalajara: Antigua Imprenta de Rodríguez, 1878.

Castillo, María José del. El convento de San Francisco, Casa Grande de Sevilla. Sevilla: Diputación Provincial, 1988.

Concilio III provincial mexicano, celebrado en México el año de 1585. Notas del R. P. Basilio Arrillaga. Publicado por Mariano Galván Rivera. México: Eugenio Maillerfert Eds., 1859. 
Complejidad y materialidad: reflexiones del Seminario del ...

Concilio IV provincial mexicano, celebrado en la ciudad de México el año 1771. Querétaro: Imprenta de la Escuela de Artes, 1898.

Concilios provinciales primero, y segundo, celebrados en la muy noble, y muy leal ciudad de México, presidiendo Fr. Alonso de Montúfar, en los años de 1555, y 1565, dalos a luz D. Francisco Antonio Lorenzana. México: en la Imprenta de el Superior Gobierno de el Br. D. Joseph Antonio de Hogal, 1769.

Estatutos ordenados por el Santo Concilio III Provincial Mexicano en el año del señor de 1585. México: Impr. de Vicente G. Torres, 1859.

Estrada, Jesús. Música y músicos de la época virreinal. Pról., revisión y notas de Andrés Lira. México: SEP, Diana, 1973.

Fernández Catón, José María. "El libro litúrgico hasta el Concilio de Trento", en VV. AA. Historia ilustrada del libro: los manuscritos. Madrid: Fundación Germán Ruipérez Sánchez, Pirámide, 1993.

Fernández de la Cuesta, Ismael. Historia de la música española. Madrid: Alianza, 1988.

Focher, Jean. Itinerario del misionero en América. Texto latino con su vers. castellana, Introd. y notas Antonio Eguiluz. Madrid: Librería General Victoriano Suárez, 1960. 
Franciscanos. Constituciones y leyes municipales de esta Prouincia del S. Euangelio hechas y recopiladas, en el Capitulo Provincial, celebrado en el Conuento de N.P.S. Francisco de México. México: por la Viuda de Bernardo Calderón, 1667.

Francisco de Asís. Regla de los frayles menores, con el Testamento del bien aventurado padre San Francisco, en latín, y en romance, y con las Declaraciones apostólicas de Nicolao III y Clemente V. Pontífices romanos. México: en casa de Pedro Balli, 1595.

- - Libro de la Regla y Constitución General de la Orden de Nuestro Padre Sant Francisco de la Observancia... Sevilla: Clemente Hidalgo, 1607.

Gestoso y Pérez, José. Ensayo de un diccionario de los artífices que florecieron en Sevilla desde el siglo XIII al XVIII inclusive. Sevilla: [Andalucía Moderna], 1899-1908.

Griffin, Clive. Los Cromberger: la historia de una imprenta del siglo XVI en Sevilla y Méjico. Madrid: Instituto de Cooperación Iberoamericana, Quinto Centenario, Eds. de Cultura Hispánica, 1991.

Huglo, Michel. Les livres de chant liturgique. Brépols : Turnhout, 1988.

Huizinga, Johan. El otoño de la Edad Media. Versión de José Gaos. Madrid: Alianza, 1990.

Iguiniz, Juan B. "Poliantea bibliográfica II”, en Boletín

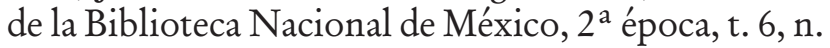
2, abril-junio de 1955. 
Complejidad y materialidad: reflexiones del Seminario del ...

Leonard, A. Irving. Los libros del conquistador. México: FCE, 1979.

Manrique, Jorge Alberto. "El arte novohispano en los siglos XVI y XVII", en Una visión del arte y de la bistoria. México: UNAM, 2001.

Mendieta, Jerónimo de. Historia eclesiástica indiana. Noticias del autor y de la obra por J. García Icazbalceta. Estudio de Antonio Rubial. México: CNCA, 1997.

Montúfar, Alonso de, fray, O. P. Ordenanzas para el coro de la catedral de México. Ed. preparada por Ernest J. Burrus. Madrid: Eds. José Porrúa Turanzas, 1964.

Navascués, Pedro. Monasterios de España. $5^{\mathrm{a}}$ ed. Madrid: Espasa Calpe, 1988.

Ocaranza, Fernando. Capitulos de la bistoria franciscana. México: el autor, 1933.

Real Academia Española. Diccionario de la Lengua Española. Madrid: Espasa Calpe, 2002.

Ricard, Robert. La conquista espiritual de México. México: FCE, 1995.

Righetti, Mario. Historia de la liturgia. Madrid: Biblioteca de Autores Cristianos, 1955-1956.

Romero de Terreros, Manuel. "Iluminadores de la época virreinal", en Miscelánea de arte colonial. México: Alianza, 1990. 
El sacrosanto y ecuménico Concilio de Trento. Traducido al idioma castellano por Ignacio López de Ayala. Agrégase el texto latino corregido según la edición auténtica de Roma, publicada en 1564. Nueva edición. París, México: Librería de Ch. Bouret, 1877.

Salgado, Silvia. Análisis semiótico de la forma arbórea en el Códice de Dresde. México: UNAM, 2001.

- - Libros de coro conservados por la Biblioteca Nacional de México. Aportaciones al estudio de las iluminaciones novohispanas de los siglos XVII y XVIII. Sevilla y México, tesis doctoral inédita presentada en la Universidad de Sevilla, 2004.

Stanford, Thomas. Catálogo de los acervos musicales de las catedrales metropolitanas de México y Puebla de la Biblioteca Nacional de Antropología e Historia y otras colecciones menores. México: INAH, Puebla: Gobierno del Estado, 2002.

Stevenson, Robert. Music in México: an bistorical survey. New York: Crowell, [1952].

Stols, Alexandre. Antonio de Espinosa: el segundo impresor mexicano. México: UNAM, 1989.

-_. Pedro Ocharte: el tercer impresor mexicano. México: UNAM, 1990.

Torquemada, Juan de, Monarquía indiana. Introd. Miguel León Portilla, México: FCE, 1963, 1969.

Torre Villar, Ernesto de la. Ex libris y marcas de fuego. México: UNAM, 2000 (c1994). 
Complejidad y materialidad: reflexiones del Seminario del ...

Torre Villar, Ernesto de la. "El libro belga en México", en Boletín del Instituto de Investigaciones Bibliográficas UNAM, n. 10, julio-diciembre de 1973.

Toussaint, Manuel. Pintura colonial en México. México: UNAM, 1990.

Tovar de Teresa, Guillermo. Un rescate de la fantasía: el arte de los Lagarto, iluminadores novobispanos de los siglos XVI y XVII. México: El Equilibrista, Madrid: Turner, 1988.

Valadés, Diego de. Retórica Cristiana. Introd. Esteban J. Palomera; Advertencia de Alfonso Castro; Preámbulo y tr. Tarsicio Herrera et al. Facsim. de la ed. de 1579. México: UNAM, FCE, 1989.

VV. AA. Diccionario de historia eclesiástica de España. Dir. Quintín Aldea et al. Madrid: Instituto Enrique Flórez, CSIC, 1972.

Yhmoff Cabrera, Jesús. Los impresos mexicanos del siglo XVI en la Biblioteca Nacional de México. México: UNAM, 1990.

Zulaica, Ramón. Los franciscanos y la imprenta en México en el siglo XVI. México: Pedro Robredo, 1939. 


\title{
De los libros surgen las leyes. Aproximación a los fondos jurídicos de las bibliotecas particulares y públicas novohispanas
}

\author{
Miguel LUQUe TALAVÁN ${ }^{1}$
}

En los libros hallo a los muertos como si estuvieran vivos; en los libros preveo las cosas que sucederán; en los libros se ponen en marcha asuntos de guerra; de los libros surgen las leyes de la paz. Todas las cosas se corrompen y decaen con el tiempo; Saturno deja de devorar a los hijos que engendra: toda la gloria del mundo quedaría enterrada en el olvido si Dios no bubiera proporcionado a los mortales el remedio de los libros.

Richard de Bury

\section{Introducción}

G s el libro un objeto mágico y uno de los más Cfieles compañeros del hombre. Como decía Jorge Luis Borges "Un libro, cualquier libro, es para nosotros un objeto sagrado". Generaciones de

1 Agradezco la gentil ayuda, colaboración y consejos que para la preparación de esta investigación me ha prestado la Doctora Marta Milagros del Vas Mingo (Universidad Complutense de Madrid. España). 
Complejidad y materialidad: reflexiones del Seminario del ...

humanos, desde que el libro es libro, han pensado de la misma forma. Gracias a eso y a la necesidad que de los mismos tuvieron para trabajar, soñar, entretenerse... es que hoy en día los historiadores interesados en la Historia del libro y de las bibliotecas podemos reconstruir el pasado intelectual de los que nos precedieron en los senderos de la vida.

La presencia de obras forenses en los anaqueles de las bibliotecas -tema principal de este trabajoqueda constatada desde los tiempos de la Antigüedad clásica. Así, la mítica Biblioteca de Alejandría contaba con una sección de "Legislación" desde que el epigramista y erudito Calímaco de Cirene (siglo III a. C.) hiciese la primera y conocida clasificación de sus fondos.

Toda preferencia y toda categoría elegida conllevan una exclusión. Puesto que mi campo principal de estudio se halla constituído por el Derecho Indiano, los libros a los que se alude en la presente investigación lo son de temática jurídica. Y a pesar de su aparente limitación temática, lo cierto es que los libros de Derecho permiten vislumbrar la realidad y el devenir histórico de las sociedades que los crearon. De ahí el interés de su estudio para los historiadores, en general, y para los historiadores del Derecho, en particular. 
De los libros surgen las leyes. Aproximación a los fondos ...

En la América española, los impresos fueron vehículos transmisores de ideas, mentalidades y actitudes. ${ }^{2}$ Es por eso que el estudio“(...) de los libros y las bibliotecas pueden contribuir también al análisis y comprensión de una generación, de una personalidad. Se ha escrito que la producción, circulación y apropiación de los libros son datos fundamentales de la bistoria de la civilización". 3

La cultura jurídica no estuvo sólo en los conventos, colegios y universidades -todas ellas poseedoras de destacadas bibliotecas institucionales-, sino también en las bibliotecas particulares de religiosos y de laicos y en las bibliotecas públicas. Era en estos lugares donde los juristas completaban y ampliaban su cultura, de ahí la importancia de su estudio.

2 "Es un hecho cierto, sin duda, que pocos artefactos bumanos reflejan el ambiente que les rodea de mejor manera que un libro. Así, pues, la bistoria del libro en Hispanoamérica colonial se vincula con asuntos tan relevantes como la asimilación religiosa de los indios, el crecimiento de las instituciones de enseñanza, la creatividad de los artistas y escritores, la transferencia de la tecnología europea y la emergencia de un protonacionalismo criollo". (Teodoro Hampe Martínez, 1996. Bibliotecas privadas en el mundo colonial. La difusión de libros e ideas en el virreinato del Perú (siglos XVI-XVII). Vervuert: Iberoamericana (teci. Textos y estudios coloniales y de la independencia. Vol. 1). Frankfurt-Madrid, p. 13).

3 Cristina Gómez Álvarez; Téllez Guerrero, Francisco. 1996. "Los libros de Antonio Bergosa y Jordán, Obispo de Antequera de Oaxaca, 1802". Acervos. Boletín de los Archivos y Bibliotecas de Oaxaca (Oaxaca). 8, 1/2 (septiembre-diciembre). 
Complejidad y materialidad: reflexiones del Seminario del ...

Un estudio que demuestra cómo la cultura libresca indiana fue muy rica y variada. El hombre del Nuevo Mundo recibía los libros impresos en Europa -incluída España- muchas veces en el mismo año de su impresión o poco tiempo después. ${ }^{4}$

Los intelectuales hispanos del Siglo de Oro estimaban a la Jurisprudencia como uno de los saberes esenciales, útiles para solucionar cuestiones públicas y privadas, eclesiásticas y seculares. En el siglo XVI, era sentir extendido en el mundo jurídico que los juristas debían poseer buenas y surtidas bibliotecas para el ejercicio de su profesión. ${ }^{5}$ Así, Melchor de Cabrera Núñez de Guzmán decía que "No

4 Javier Malagón Barceló.1959. La Literatura jurídica española del Siglo de Oro en la Nueva España, Notas para su Estudio. Instituto Bibliográfico Mexicano: Biblioteca Nacional de México, México, p. 13.

5 Daisy Rípodas Ardanaz. 1975. Bibliotecas privadas de funcionarios de la Real Audiencia de Charcas. Caracas: Academia Nacional de la Historia. [Es tirada aparte de Memoria del II Congreso Venezolano de Historia (18 al 23 de noviembre de 1974). Academia Nacional de la Historia. Caracas, tomo II, pp. 501-555], p. 536. 
De los libros surgen las leyes. Aproximación a los fondos ...

(...) se empobrece, ni (...) gasta mal la hazienda el que la emplea en libros, siendo Iurisperito; (...)". ${ }^{6}$

En opinión de no pocos autores estas extensas colecciones debían servir al jurista para formarse ideas precisas de cualquier materia, ${ }^{7}$ siéndoles por tanto útil para el estudio de la jurisprudencia. ${ }^{8}$

Entre el equipaje de los pasajeros a Indias era frecuente encontrar libros de Derecho. Así, las autoridades civiles o los abogados, cuando embarcaban rumbo a sus destinos indianos solían transportar en sus baúles libros jurídicos para ayudarles en sus ta-

6 Melchor de Cabrera Núñez de Guzmán. 1683. Idea de un abogado perfecto, reducida a practica; deducida de reglas, y disposiciones del Derecho, comprobada con la autoridad de sus Interpretes. Ilustrada Con letras Divinas, Santos, y Doctores, y Padres de la Iglesia. Esmaltada Con varias flores de todas letras. Y conforme A la Vida de San Ivon, Patron, y Patriarca de los Abogados. Que ofrece, decica y consagra al Ilustrissimo, y Reverendissimo senor Don Fray Ivan Assensio, Obispo de Iaen, del Consejo de su Magestad, y Presidente de Castilla, y a los Muy Ilustres, y Nobilissimos Señores del Consejo, Padres conscriptos de la Iusticia, Principes de la Iurisprudencia, y Protectores de los Abogados, el Licenciado Don Melchor de Cabrera Nuñez de Guzmàn, Abogado de los Consejos, Alcaide de la Fortaleza de la Villa de Guardo, y Alcalde de la de Torre de Lobaton por el Estado de Hijosdalgo. En la Oficina de Eugenio Rodriguez, Madrid, p. 220. En la misma línea véanse las páginas 210, 211 y siguientes.

7 Ibídem, pp. 210-211.

8 Francisco Bermúdez de Pedraza. 1612. Arte legal para estudiar la Jurisprudencia. Salamanca, pp. 158-159. (Citado en: Rípodas Ardanaz, 1975, p. 536, nota número 118). 
reas administrativas o profesionales. Llevando además libros de cultura general, de entretenimiento y de religión. ${ }^{9}$ Del mismo modo resultaba habitual el envío de libros entre particulares avecindados en distintos puntos de los territorios indianos, incluso a los más distantes. ${ }^{10}$

Sin embargo y a pesar de la importancia de algunas bibliotecas privadas en manos de laicos, fueron

9 Como ejemplo puede mencionarse el expediente que en 1802 promovió Francisco Josef de Urrutia ante la Inquisición para que le fuese otorgado permiso del Santo Tribunal para la entrega de los libros de su oficio -posiblemente abogado- y piadosos que llevaba en su equipaje y que fueron requisados -como disponía la legislación- por la Real Aduana de la ciudad de México. Dicho documento no ofrece la relación de los libros (Archivo General de la Nación (México) -asentado de aquí en adelante como AGN-. Inquisición. Volumen: 1408. Expediente: 10. Folio 97 recto). Este tipo de expedientes abundan en el legajo citado: AGN . Inquisición. Volumen: 1408. Expediente: 11. Folios 98 recto-98 vuelto. AGN. Inquisición. Volumen: 1408. Expediente: 12. Folios 99 recto-99 vuelto. AGN. Inquisición. Volumen: 1408. Expediente: 13 . Folios 100 recto-116 vuelto.

10 Caso de los libros enviados por el Hermano Manuel Duarte, de la Compañía de Jesús, a un destinatario desconocido en Manila, capital de la Gobernación y Capitanía General de las islas Filipinas. Es interesante resaltar como entre los libros remitidos había dos tomos de la Política Indiana de Juan de Solórzano Pereira (AGN Inquisición. Volumen: 438 (2). Expediente: 50. Folio 509 recto). 
las de los religiosos las más ricas. Las cuales eran nutridas regularmente con nuevas obras. ${ }^{11}$ En ellas, además de los libros con licencia, había libros prohibidos para los cuales, a veces, no tenían autorización especial. ${ }^{12}$ Famosa fue, por poner únicamente un ejemplo, la librería del primer Obispo y, luego, Arzobispo de México Fray Juan de Zumárraga; la cual llegó a contar con 400 ejemplares que, parece ser, puso al servicio público. ${ }^{13}$

11 Como muestra citar un envío, efectuado en 1802, de cuatro cajones de libros para el Convento de San Agustín de la ciudad de México. Los cajones contenían cincuenta juegos de los opúsculos de San Agustín, en siete tomos cada juego. Habiendo sido impresos recientemente en Madrid (AGN. Inquisición. Volumen: 1408. Expediente: 13. Folio 100 recto).

12 José Torre Revello. 1991. El libro, la imprenta y el periodismo en América durante la dominación española. Universidad Nacional Autónoma de México, Instituto de Investigaciones Bibliográficas. México [primera edición facsimilar: 1991]. [Facsímil de la obra: Torre Revello, José. 1940. El libro, la imprenta y el periodismo en América durante la dominación española. Con ilustraciones y apéndice documental. Noticia Preliminar por Emilio Ravignani. Facultad de Filosofía y Letras (Publicaciones del Instituto de Investigaciones Históricas. Número LXXIV). Buenos Aires, p. 121.

13 Fray Juan de Zumárraga, de sus libros “"(...) que eran muchos y buenos, mandó dar [en su textamento] la mayor parte al Convento de San Francisco [de México] para compensar a la Orden los que pertenecientes a ella había traído de España con licencia, y unos pocos destinó a la hospedería de Durango, su patria"”. (García Icazbalceta, Joaquín. Biografía de Fr. Juan de Zumárraga... p. 248. Citado en: Torre Revello, 1940. [Edición facsimilar. México: 1991], p. 121, nota número 3). En relación a la biblioteca fundada por 
Complejidad y materialidad: reflexiones del Seminario del ...

\section{Alfonso García-Gallo de Diego, ${ }^{14}$ primero, y}

Fray Juan de Zumárraga en la Catedral de México, véase: Carreño, Alberto María. 1943. "La primera biblioteca del Continente americano". Divulgación Histórica (México). p.p. 8-431. IV/8 (15 de junio). Carreño, Alberto María. 1943. "La primera biblioteca del Continente americano”. Divulgación Histórica (México). Pp. 488-492. IV/9 (15 de julio). Sobre esta biblioteca, podemos leer: "(...) el texto de la Real Cédula que en 1534 le expidió a este propósito el emperador Carlos $V$, (...). "Por quanto por parte de vos, el reverendo in Christo padre don Fray Juan de Zumárraga, obispo de México, me ha sido hecha relación que la Iglesia Catedral de la cibdad de México tenía necesidad de una librería, a causa de los casos y dubdas que cada día en aquella tierra se ofrecían, y me fue suplicado mandase declarar de qué parte de los diezmos se compraría e harían los gastos necessarios a la dicha librería tocantes, o como la mi merced fuese. Por ende, por la presente declaro y mando que de lo de la fábrica de la dicha iglesia catedral se gaste y distribuya la quinta parte por tres años primeros siguientes, para hacer la dicha librería y no para otra cosa alguna, o menos, lo que a vos el dicho Obispo pareciere que basta. Fecha en Toledo, a 21 del mes de mayo de mil e quinientos e treinta e quatro años. Yo el Rey. Por mandado de su Magestad, Cobos, comendador mayor." (Millares Carlo, Agustín. 1970. "Bibliotecas y difusión del libro en Hispanoamérica colonial: intento bibliográfico". Boletín Histórico (Caracas). p.p. 44-45. 22). Martínez, José Luis. 2003. "Las primeras bibliotecas públicas en Nueva España", en VV.AA. Biblioteca Palafoxiana. Artes de México (México, D.F.). p. 34, 68 .

14 Alfonso García-Gallo [de Diego]. 1970. Metodología de la Historia del Derecho Indiano. Editorial Jurídica de Chile. Santiago de Chile, p. 185. 
De los libros surgen las leyes. Aproximación a los fondos ...

José María Castán Vázquez, ${ }^{15}$ después, expusieron que para estudiar la cultura jurídica indiana era conveniente consultar las relaciones de libros formalizadas ante la Casa de la Contratación de Sevilla antes de su embarque a Indias. Listas que se custodian en el Archivo General de Indias (Sevilla). A estas relaciones hay que sumar los autos de bienes de difuntos conservados también en el repositorio sevillano. Personalmente he utilizado ambas fuentes a través de documentación inédita proveniente de este Archivo. Del mismo modo han sido examinados los fondos que sobre embarque de libros y bienes de difuntos se guardan en el Archivo Histórico Nacional (Madrid) y en el Archivo General de laNación (México). Así como la documentación que se haya trascrita y/o estudiada en la bibliografía

15 "Sería sugestiva, (...), una investigación dirigida a descubrir cuáles fueron las obras jurídicas que, a lo largo de los siglos XVI y XVII llegaron (...) a tierras americanas. Las fuentes principales de esa investigación, necesariamente laboriosa, serían los catálogos e inventarios de las bibliotecas americanas antiguas y los registros que en el Archivo de Indias se conservan de las cargas de las naves. (...).” (Castán Vázquez, José María. 1984. La Influencia de la Literatura jurídica Española en las Codificaciones Americanas; discurso leído el día 23 de enero de 1984, en su recepción pública, por el Excmo. Sr. Don José María Castán Vázquez y contestación del Excmo. Sr. Don Antonio Hernández Gil Presidente de la Academia. Real Academia de Jurisprudencia y Legislación. Madrid, p. 35, nota número 24). 
existente. Bibliografía que además no siempre es minuciosa a la hora de aportar datos sobre el contenido concreto de las bibliotecas particulares, lo que dificulta la identificación de autores y obras.

La bibliografía existente acerca de la Historia del libro y de las bibliotecas en la América hispánica puede llevarnos a pensar que todo está investigado en relación a esta cuestión. Sin embargo quedan aun muchas lagunas por cubrir, especialmente $-\mathrm{y}$ relacionado con el tema aquí tratado- en el campo del contenido jurídico de las bibliotecas indianas. ${ }^{16}$

16 A la Historia del libro y de las bibliotecas en la América española se han dedicado muchos investigadores. A pesar de lo cual sigue sin haber una obra de conjunto, debido muy posiblemente a la ingente cantidad de material existente. Mientras, la Historia de los libros jurídicos ha sido un área descuidada por los especialistas en el Derecho Indiano. Siendo pocos los trabajos que existen sobre la cuestión a pesar de ser de las más importantes para un conocimiento completo de la disciplina. A modo orientativo, véanse las bibliografías que sobre la Historia del libro y de las bibliotecas incluyen: Solano [Pérez-Lila], Francisco [de Paula] de. 1985. "Fuentes para la historia cultural: libros y bibliotecas de la América colonial”, en Pino Díaz, Fermín del (coordinador). Ensayos de metodología histórica en el campo americanista. Consejo Superior de Investigaciones Científicas, Centro de Estudios Históricos, Departamento de Historia de América (1. Anexos de la Revista de Indias). Madrid, pp. 74-84. Dadson, Trevor J. 1994. "Libros y lecturas sobre el Nuevo Mundo en la España del Siglo de Oro”. Histórica (Lima). Pp. 15-26. XVIII/1 (julio). González Sánchez, Carlos Alberto. 1999. Los mundos del libro. Medios de difusión de la cultura occidental en las Indias de los siglos XVI y XVII. 
De los libros surgen las leyes. Aproximación a los fondos ...

Antes de pasar a referir algunos ejemplos de lo expuesto procedentes del Virreinato de la Nueva España, no quiero dejar de explicar la razón del título del presente estudio. Siendo la literatura jurídica -en los sistemas jurídicos del Antiguo Régimen- una de las fuentes del Derecho (junto con la ley, la costumbre y la jurisprudencia de los tribunales), parecía adecuado usar de tal epígrafe para resaltar las importancia de las obras que a continuación van a ir siendo referidas y clasificadas. Muchas de las cuales tuvieron, en su momento, un papel muy destacado en la creación del Derecho de los diversos espacios en donde fueron, o para los que fueron, escritas. ${ }^{17}$

Prólogo de León Carlos Álvarez Santaló. Diputación de Sevilla: Universidad de Sevilla (Serie: Historia y Geografía. Núm.: 43). Sevilla, pp. 207-212.

17 Un análisis del papel de la literatura jurídica como una de las fuentes del Derecho en: Luque Talaván, Miguel. 2003. Un universo de opiniones. La literatura jurídica indiana. Prólogo de Marta Milagros del Vas Mingo. Consejo Superior de Investigaciones Científicas, Instituto de Historia (Colección: Biblioteca de Historia de América; 26). Madrid. Capítulo I "La literatura jurídica como fuente del Derecho Indiano”, pp. 69-113. 


\section{Libros de derecho en bibliotecas particula- res del Virreinato de la Nueva España (si- glos XVI-XIX) ${ }^{18}$}

El humanista Francisco Cervantes de Salazar, que tras una exitosa carrera en la Península pasó a la Nueva España en 1551 donde fue el primer maestro de Retórica de la Universidad Real y Pontificia de México, ${ }^{19}$ poseyó una importante biblioteca que, a su muerte, fue vendida con el resto de sus bienes en almoneda en los días 12 de diciembre de 1575 y 26 de mayo de 1576. La librería se componía de 369 ejemplares, contando con obras de Aristóteles, Ptolomeo, Esopo, Séneca, Tácito, Marcial, Salustio, etcétera. Y de los grandes autores cristianos: Agustín, Ambrosio, Dionisio, Gregorio Nacianceno, Santo Tomás de Aquino, etcétera. Los libros

18 En este capítulo se citan numerosas obras de Derecho de diferentes épocas. Los antiguos inventarios, y algunos investigadores contemporáneos, no son muy exactos en lo que a datos bibliográficos se refiere. Por lo que en muchas ocasiones se han tenido que documentar las referencias que los mismos ofrecen. Al faltar el lugar de impresión y el año de edición en la mayoría de ellas, se han recogido en este capítulo las ediciones más antiguas de las obras citadas. Para diferenciar las referencias íntegras en su origen de las por mi completadas he marcado a las segundas con un aterisco.

19 José Luis Abellán. 1979. Historia crítica del pensamiento español. Tomo II. La Edad de Oro. Espasa Calpe. Madrid, pp. 156-161. 
De los libros surgen las leyes. Aproximación a los fondos ...

jurídicos se hallaban también presentes con obras de autores como François Balduin, Juan Bautista Mantuano, Dino da Mugello, Bernardo Díaz de Lugo, Jean Capreole, Filipo Decio, Azzone dei Porci, Hugo de Celso, Diego de Covarrubias y Leiva, Domingo de Soto, Pietro Lombardo, etcétera. Así como de los textos clásicos: Decreto de Graciano, glosas a las Leyes de Toro, comentarios a las Instituta y al Corpus, etcétera.

Asimismo se constata que en 1595 remitieron al Doctor Diego de Villanueva Zapata, Oidor de la Real Audiencia de Panamá, 44 libros, todos ellos de jurisprudencia. ${ }^{20}$

De los numerosos registros de libros que he podido consultar en el Archivo General de la Nación (México), algunos ofrecen datos acerca de obras jurídicas. Así, un inventario realizado en la librería que Simón de Toro poseía en la ciudad de México, el 15 de abril de 1634, arroja la cifra de seis libros de Derecho: Derecho civil y canónico, Vocabulario de Elio Antonio de Lebrija, ${ }^{21}$ el tomo $4^{\circ}$ de las Disceptaciones forensis de Gratiano, Conciliis tridentini y

20 Torre Revello, 1940. [Edición facsimilar. México: 1991], pp. 119-120, nota número 1. Dicha relación se halla reproducida en: Ibídem, "Apéndice", número 31, pp. XLIX-LI.

21 Antonio de Nebrija. 1506. Juris civilis lexicon/Pomponii Laeti de Romanorum magistratibus... d M. Pantagalbum libellus. [S.n.]. Salmanticae. 
Complejidad y materialidad: reflexiones del Seminario del ...

la Practica de Paz. ${ }^{22}$ En 1558 el Capitán Juan de Cabueñas, vecino de la ciudad de México, recibió el encargo de vender en la Nueva España unos cajones de libros a él remitidos por el mercader de libros Nicolás Rodríguez, vecino de Sevilla. De todos ellos había ocho ejemplares de la Nueva Recopilación, cinco de De Iudiciis de Tomás Carleval y dos Sumaria Concilia Criminali. ${ }^{23}$ De 13 de diciembre de 1660 data una calificación que la Inquisición novohispana hizo a un libro propiedad del Doctor Sebastián Muñoz de Velasco, Abogado de la Real Audiencia de México, titulado Cuerpo de Derecho canónico y civil. ${ }^{24}$ En otro expurgo fechado en la ciudad de México el 5 de junio de 1679, se calificaron unas Disputationes ad instituta imperialia, Contradichones juris canonici, dos obras de

22 AGN. Inquisición. Volumen: 165. Expediente: (4) 27. Folios: 38 recto-39 vuelto.

23 AGN. Inquisición. Volumen: 438 (2). Expediente: 51. Folios: 517 recto-519 recto.

24 Cuerpo de Derecho canónico y civil. MDLV. Apud Sennetonios fratres. Lugduni ad Salamandre.

25 AGN. Inquisición. Volumen: 438 (2). Expediente: 77. Folios: 640 recto-641 vuelto. 
De los libros surgen las leyes. Aproximación a los fondos ...

Arnoldo Vinnio, ${ }^{26}$ Tractatus quinque de pactis ${ }^{27}$ y una Interpretación del derecho civil. ${ }^{28}$ En 1716, Agustín Pérez del Castillo, mercader de libros en ciudad de México, presentó una relación de los que obraban en su poder para su venta donde figuran algunos títulos de Derecho. ${ }^{29}$ En la biblioteca del Licenciado Pascual de Cárdenas, natural de Cuzco y Abogado de la Real Audiencia de México, abundaban -debido a su profesión-las obras de Derecho. ${ }^{30}$ Del mismo modo en el inventario y secuestro de bienes en la casa de la viuda de Marín, efectuado en 1790, figuran muchas obras jurídicas. ${ }^{31}$ Así como

26 Arnoldo Vinio. 1665. In quatuor libros institutionum imperialium commentarius Academicus et forensis, editio quarta. Apud Danielem Elsevirium. Amstelodami. Vinnius, Arnoldus. Arnoldi Vinni Juris C. Jurisprudentiae contractae, sive partitionum Juris civilis libri IV. Ex officina Ioannis Narani. Roterodami.

27 Tractatus quinque de pactis. Juris dict. Collat. transsachonilq. et ques boneb q Juris.

28 AGN. Inquisición. Volumen: 639. Expediente: 5. Folios: 224 recto-225 vuelto.

29 AGN. Inquisición. Volumen: 763. Expediente: 2. Folios: 326 recto-356 vuelto.

30 AGN. Real Fisco de la Inquisición. Volumen: 136. Expediente: 2. Folios: 141 vuelto-145 recto.

31 AGN. Real Fisco de la Inquisición. Volumen: 136. Expediente: 2. Folios: 77 vuelto-81 vuelto. 
también las hay entre los bienes embargados en 1797 al Licenciado Pascual de Cande, residente en Guanajuato. $^{32}$

Antonio Álvarez de Castro, Oidor de la Real Audiencia de Manila y Presidente de la Real Audiencia de Guadalajara (siglo XVII), poseía una biblioteca de 56 títulos, con 63 tomos, donde abundaban los de temática jurídica: ${ }^{33}$ Jerónimo Castillo de Bobadilla, ${ }^{34}$ José de Veitia Linage, ${ }^{35}$ Juan de Hevia Bolaño, ${ }^{36}$ Juan Francisco de Montemayor y Córdoba de

32 AGN. Real Fisco de la Inquisición. Volumen: 136. Expediente: 2. Folios: 67 recto-70 vuelto.

33 José Luis Barrio Moya. 1990. "La librería de don Antonio Álvarez de Castro, Presidente de la Audiencia de Guadalajara (México) durante el reinado de Carlos II". Anuario de Historia del Derecho Español (Madrid). Pp. 489-496. LIX.

34 Jerónimo Castillo de Bobadilla. 1597. Política para corregidores y señores de vassallos, en tiempos de paz y de guerra, y para juezes ecclesiasticos y seglares, $y$ de saca, aduanas, $y$ de residencias, $y$ sus oficiales: y para regidores y abogados: y del valor de los Corregimientos, y gobiernos realengos, y de las ordenes. Luis Sánchez. Madrid.

35 José de Veitia Linage. 1672. Norte de la contratación de las Indias Occidentales. J. F. de Blas. Sevilla.

36 * Juan de Hevia Bolaño. 1609. Curia Philipica, donde breve y comprehendiosamente se trata de los juyzios mayormente forenses, eclesiasticos y secualres, con lo sobre ello hasta aora dispuesto por derecho resuelto por doctores antiguos y modernos, y practicable. Por Iuan Godinez de Millis. Valladolid. 
De los libros surgen las leyes. Aproximación a los fondos ...

Cuenca, ${ }^{37}$ Francisco Anaya,${ }^{38}$ Diego Saavedra y Fajardo $^{39}$ y otros. ${ }^{40}$

Exponer que, en relación a la Nueva España, Javier Barrientos Grandón realizó una interesante y útil relación de los autores y tendencias doctrinarias jurídicas presentes en las bibliotecas novohispanas. De las numerosas librerías por él revisadas, he seleccionado 8 por la variedad y riqueza de sus fondos jurídicos. $\mathrm{Su}$ contenido, unido al ya presentado en páginas anteriores, ofrece, considero, un panorama bastante preciso de la cultura jurídica libraria de los novohispanos de la época virreinal. Son las que pertenecieron a los siguientes personajes: 1. Antonio Bergoza y Jordán (17?-1820) Obispo de Oaxaca; 2. Sebastián Calvo de la Puerta (1717-1767) Alcalde del Crimen de la Real Audiencia de México y Oidor de la Real Audiencia de Guatemala; 3. Fray Francisco de la Cuesta (16?-1723) Arzobispo de Manila y Obispo electo de Michoacán;

37 Juan Francisco Montemayor y Córdoba de Cuenca. 1658. Discurso político, bistórico, jurídico, del derecho y repartimiento de presas y despojos apprehendidos en justa guerra: premios y castigos de los soldados. Por Iván Ruiz. México.

38 Francisco de Amaya. 1625. Observationum Iuris: libri tres. Excudebat Antonia Ramirez. Salmanticae.

39 Diego Saavedra y Fajardo. 1646. Corona gotica castellana y austriaca. Casa de Juan Jansania. Muster.

40 Tractatus nobilitate. 3 tomos de Derecho canónico. 2 tomos de la Recopilación. Pandectas. 


\section{Doctor Manuel Ignacio González del Campillo (1740-1813) Obispo de Puebla; 5. Doctor Francisco Pablo Matos Coronado (16?-1744) Obispo de Mi- choacán; 6. José Manuel Messia de la Cerda y Vargas (1695-1760) Alcalde del Crimen de la Real Audiencia de México; 7. Pedro Anselmo Sánchez de Tagle (17?-1777) Obispo de Durango; y 8. Doctor José Ru- bio y Salinas Arzobispo de México. ${ }^{41}$}

41 Para confeccionar esta relación, el Doctor Barrientos Grandón utilizó inventarios de bibliotecas -conventuales, de eclesiásticos y de laicos-; descripciones de librerías; y memorias de libros presentadas por los libreros a la Inquisición, fechadas entre los siglos XVI a XVIII (véase la relación de la documentación empleada en: Barrientos Grandón, Javier. 1993. La cultura jurídica en la Nueva España. (Sobre la recepción de la tradición jurídica europea en el virreinato). Universidad Nacional Autónoma de México (Instituto de Investigaciones Jurídicas. Serie A: Fuentes, a) Bibliografías, núm. 3). México, pp. 139-144). A pesar del amplio abanico de fuentes utilizadas, dicho autor únicamente ofrece, en la mayoría de los casos, el título de la obra, sin aportar los datos bibliográficos completos de la misma -ciudad de impresión, impresor, año de edición-. No obstante, y deseando añadir esa información, se ha optado por indicar en nota a pie de página la edición más antigua de la que tengo constancia incluyendo todos sus datos catalográficos. Seguro de que así se prestará un mejor servicio a la comunidad científica interesada en las obras que a lo largo de las siguientes páginas se irán mencionando. Advertir, por último, que por razones de espacio no pueden explicarse aquí las clasificaciones jurídicas en que se han agrupado las obras referenciadas. Un análisis in extenso de las mismas en: LuqueTalaván, 2003. Véase también nota número 18 . 
De los libros surgen las leyes. Aproximación a los fondos ...

1. Antonio Bergoza y Jordán (17?-1820) Obispo de Oaxaca poseía fuentes romanas -Corpus Iuris Civilis-, fuentes canónicas -Corpus Iuris Canonici, Concilio Tridentino, y Tercer Concilio Mexicano-, textos de legislación real -Siete Partidas, ${ }^{42}$ Nueva Recopilación de Castilla, Recopilación de Indias, Ordenanzas de Intendentes, y Eusebio Ventura Beleña ${ }^{43}$-, obras de comentaristas de fuentes canónicas inscritos en el mos italicus tardío -Andreae Vallensis, ${ }^{44}$ Manuel

42 La obra citada con el título abreviado Siete Partidas ha sido identificada como la obra: ‘Las Siete partidas del Sabio Rey don Alonso el nono, nuevamente glosadas por el Licenciado Gregorio López del Consejo Real de Indias de Su Magestad. M.D.L.V. Por Andrea de Portonaris. Salamanca.

43 La obra citada con el título abreviado: Eusebio Ventura Beleña. Recopilación sumaria de todos los autos acordados de la Real Audiencia y Sala del Crimen de esta Nueva España, ha sido identificada como la obra: *Beleña, Eusebio Ventura [o Buenaventura]. 1787. Recopilación sumaria de todos los autos acordados de la Real Audiencia y Sala del Crimen de esta Nueva España. F. de Zúñiga y Ontiveros. México. 2 volúmenes.

44 La obra citada con el título abreviado: Andrés Vallensis. Paratitla ac methodica explicatalium Gregorii IX summaria ac methodica explicatio, ha sido identificada como la obra: "Vallensis, Andreae [o André del Vaulx] 1796. Paratitla juris canonici sive decretalium d. Gregorii papae IX. Summaria ac methodica explicatio. Opus scholae ac foro $\mathcal{E}$ decretis Concilii tridentini accommodatum. Editio secunda matritensis. Ex Typographia Placidi Barco Lopez. [Matriti]. 


\section{González Téllez, ${ }^{45}$ Vito Pichler, ${ }^{46}$ Próspero Fagnanus, ${ }^{47}$ Zeger Bernardo Van Espen, ${ }^{48}$ Juan Nicolás Hontheim, ${ }^{49}$ y Julio Lorenzo}

45 La obra citada con el título abreviado: Manuel González Téllez. Commentaria perpetua in singulos textus quinque librorum Decretalium, ha sido identificada como la obra: *González Téllez, Manuel. 1673. Commentaria perpetua in singulos textus quinque librorum Decretalium Gregorii IX. Sumptibus Laurentii Arnaud, \& Petri Borde. Lugduni.

46 La obra citada con el título abreviado: Vito Pichler. Ius Canonicum secundum quinque Decretalium titulos Gregorii Papae IX, ha sido identificada como la obra: "Pichler, Vitus. 1735. Ius canonicum practice explicatum: seu decisiones cassuum ad singulos decretalium Gregorii Papae IX. Titulos, et ad consuetum referendimodum accommodatae. Sumptibus Joannis Andreae de la Haye. Ingolstadii.

47 Tras consultar varios repertorios bibliográficos no ha sido posible identificar la obra citada bajo el título abreviado: van Espen, Zeger Bernardo. Ius Canonicum universum clara methodo iuxta titulos quinque librorum Decretalium in quaestionem distributum.

48 Tras consultar varios repertorios bibliográficos no ha sido posible identificar la obra citada bajo el título abreviado: van Espen, Zeger Bernardo. Ius Canonicum universum clara methodo iuxta titulos quinque librorum Decretalium in quaestionem distributum.

49 La obra citada con el título abreviado: Juan Nicolás Hontheim. De statu ecclesiae deque legitima potestate romani Pontificis liber singularis ad reuniendos disidentes in religione constitutus, ha sido identificada como la obra: 'Hontheim, Juan Nicolás [o Justino Febronio, o Johann Nikolaus von Hontheim]. 1768. De statu ecclesiae et legitima potestate: Romani Pontificis liber singularis ad reuniendos dissidentes in religione christianos compositus Justini Febronii. 3. ed. priore emendatior et multo auctior. Apud Guillelmun Everardi. Bullioni. 1768. 
Selvagio ${ }^{50}$-, obras de comentaristas de Derecho real inscritos en el mos italicus tardío -Antonio Gómez $^{51}$-, obras de decisionistas inscritos en el mos italicus tardío -Juan Bautista de Luca ${ }^{52}-$, obras de controversistas inscritos en el mos italicus tardío -Juan Yáñez Parladorio ${ }^{53}$ y Tomás

50 La obra citada con el título abreviado: Julio Lorenzo Selvagio. Institutionum Canonicarum, ha sido identificada como la obra: *Selvagio, Giulio Lorenzo. 1784. Institutionum canonicarum libri tres ad usum seminerii neapolitani. De. nova matritensis ceteris nevera correctior. Apud Placidum Barco Lopez. [Matriti]. 3 volúmenes.

51 La obra citada con el título abreviado: Antonio Gómez. Commentarium absolutissimum ad Legum Tauri, ha sido identificada como la obra: *Gómez, Antonio. 1552. Opus praeclarum et commentum super legibus Tauri / editum per egregium et subtilem Doctorem Antonium Gomez. Excudebat Andreas a Portonariis. Salmanticae.

52 La obra citada con el título abreviado: Juan Bautista de Luca. Sacrae rotae Romanae Decisiones, ha sido identificada como la obra: *Luca, Cardenal Juan Baustista de. 1759. Sacrae rotae romanae Decisiones, et sumomorum pontificum constitutiones recentissimae, Theatrum verita et justitae. Ex typographia Balleoniana. Venetiis.

53 La obra citada con el título abreviado: Juan Yáñez Parladorio. Quotidianarum differentiarum sesquicenturia, ha sido identificada como la obra: *Yáñez Parladorio, Juan. 1604. Rerum quotidianarum libri duo. Typographia regia. Matriti. 
Carleval ${ }^{54}-$, obras de tratadistas inscritos en el mos italicus tardío - Antonio Ayerve de Ayora, ${ }^{55}$ Nuño de Acosta, ${ }^{56}$ Juan Escobar del Corro, ${ }^{57}$

54 La obra citada con el título abreviado: Tomás Carlevalio. Disputationum iuris variarum de iudiciis, ha sido identificada como la obra: *Carleval [o Carlevalio], Tomás. 1649. Disputationum iuris variarum ad interpretationem regiarum legum regni Castellae, et illis similium, tam ex iure neapolitano, quam ex utroque communi civili, et canonico. Apud Mariam Quignonii. Madriti. 2 tomos en 1 volumen.

55 La obra citada con el título abreviado: Antonio Ayerve de Ayora. De bonorum partitionibus tractatum, ha sido identificada como la obra: *Ayerve de Ayora, Antonio. 1623. Tractatus de partitionibus bonorum communium inter maritum, et uxorem $\mathcal{E}$ filios ac haeredes eorum: et fructibus dividendis tam haereditatum, quàm bonorum maioratus inter successores, E pradecesores uxores... Apud Ioannem de Rueda typographum. Vallisoleti.

56 La obra citada con el título abreviado: Nuño de Acosta. De privilegiis creditorum tractatus absolutissimum, ha sido identificada como la obra: *Acosta, Nuño de. 1739. De privilegiis creditorum: tractatus absolutissimus in quo celebriores, $\mathcal{E}$ in uso forensi frequentiores quaestiones de praeferentis creditorum discutiuntur, $\mathcal{E}$ solidissima doctrina resolvuntur. Sumptibus Haeredum Cramer et fratum Philibert. Genevae.

57 La obra citada con el título abreviado: Juan Escobar del Corro. Tractatum bipartitum, ha sido identificada como la obra: "Escobar del Corro, Juan. 1634. Tractatus bipartitus de puritate et nobilitate probanda secundum statuta S. Officii inquisitionis regii ordinum senatus, sancta ecclesia Toletana, collegiorum, aliarumque communitatum bispania... Excudebat Philippus Gamonetus. Geneva. 


\section{Alfonso de Olea, ${ }^{58}$ Hermenegildo de Roxas, ${ }^{59}$ Nicolás García, ${ }^{60}$ Francisco de Mostazo, ${ }^{61}$ Fran-}

58 La obra citada con el título abreviado: Alfonso de Olea. Tractatus de cessione iurium et actionum, ha sido identificada como la obra: *Olea, Alfonso de. 1740. Tractatus de cessione iurium et actionum: in quo insertae sunt, suo loco, additiones, seu resolutiones tam authoris quam aureae Cencinii. Officina De Tournes. Lugduni, 2 volúmenes.

59 La obra citada con el título abreviado: Hermenegildo Roxas. Tractatus posthumus de incompatibilitate regnorum ac maioratum, ha sido identificada como la obra: *Aguila y Roxas, Fernando Alfonso del. 1738. Additae quaestiones de incompatibilitate regnorum \& maioratuum, ad Tractatum d. Hermenegildi de Roxas... quem in lucem editum vidit curâ E studio d. Francisci Ximenes del Aguila... ubi plura utilissima et noviter discursa in materia resolvuntur, E decisionibus tribunalium Hispaniae, maximè Granatensis senatus, comprobata, ad praxim utiliter inveniuntur. Sumptibus fratrum de Tournes. Coloniae Allobrogum.

60 Tras consultar varios repertorios bibliográficos no ha sido posible identificar la obra citada bajo el título abreviado: Nicolás García. De beneficiis tractatus.

61 La obra citada con el título abreviado: Francisco de Mostazo. Tractatus de Causis piis, ha sido identificada como la obra: "Mostazo, Francisco de. 1686. De causis piis ingenere, et in specie Libri VIII: opus quidem perutile non solum iudicibus y Visitatoribus Ecclesiasticis, verum etiam secularibus... Tomus primus: diligenter recognitus, multisque mendis expurgatus... Sumptibus Petri Borde, Joannis, y Petri Arnaud. Lugduni. 


\section{cisco Salgado de Somoza, ${ }^{62}$ Gaspar de Villa- rroel, ${ }^{63}$ Pedro Frasso, ${ }^{64}$ Antonio Joaquín de}

62 La obra citada con el título abreviado: Francisco Salgado de Somoza. De regia protectione, ha sido identificada como la obra: "Salgado de Somoza, Francisco. 1626. Tractatus de regia protectione vi oppressorum appellantium à causis $\mathcal{E}$ indicibus ecclesiasticis. Sumpt. L. Prost., haeredis Roville. Lugduni, 2 volúmenes. La obra citada con el título abreviado: Francisco Salgado de Somoza. Tractatus de supplicatione ad Sanctissimum, ha sido identificada como la obra: "Salgado de Somoza, Francisco. 1664. Tractatus de supplicatione ac Sanctissimum Aliteris et de earum retentione intermin senatu. $1^{a} \mathrm{ed}$. Sumptibus Lartentii Anissan. Lyancase. La obra citada con el título abreviado: Francisco Salgado de Somoza. Labyrinthus creditorum, ha sido identificada como la obra: "Salgado de Somoza, Francisco. 1653. Labyrintbus creditorum concurrentium ad litem per debitorem communem inter illos causatam. Apud Iacobum Meursium. Antuerpiae, 2 volúmenes.

63 La obra citada con el título abreviado: Gaspar de Villarroel. Gobierno eclesiástico pacífico y..., ha sido identificada como la obra: *Villarroel, Arzobispo Gaspar de. 1656. Govierno eclesiástico pacífico, y union de los dos cuchillos, pontificio, y regio. Domingo García Morràs. Madrid, 2 volúmenes.

64 La obra citada con el título abreviado: Pedro Frasso. De regio patronatu, ha sido identificada como la obra: *Frasso, Pedro. 1677-1679. De regio patronatu: ac aliis nonnullis regaliis, regibus catholicis, in Indiarum Occidentalium Imperio, pertinentibus, quaestiones aliquae desumptae, et disputatae. In quinquaginta capita partitae. Ex Typographia Imperiali: apud Iosephum Fernandez á Buendia. Matriti, 2 tomos en 3 volúmenes. 
Rivadeneyra y Barrientos, ${ }^{65}$ Antonio José Álvarez de Abreu, ${ }^{66}$ y Conde de la Cañada ${ }^{67}$-, obras de prácticos inscritos en el mos italicus tardío -Juan de Hevia Bolaños ${ }^{68}$ y Alfonso de Villadie-

65 La obra citada con el título abreviado: Antonio Joaquín de Rivadeneyra y Barrientos. Manual compendio..., ha sido identificada como la obra: "Rivadeneyra y Barrientos, Antonio Joaquín de. 1755. Manual compendiado de el regio patronato indiano: para su mas facil uso en las materias conducentes á la práctica. Antonio Marín, Madrid.

66 La obra citada con el título abreviado: Antonio José Álvarez de Abreu. Victima real legal..., ha sido identificada como la obra: *Álvarez de Abreu, Antonio José. 1726. Victima Real legal, discurso unico jurídico-histórico-político sobre que las vacantes mayores, y menores de las Iglesias de las Indias Occidentales, pertenecen a la Corona de Castilla, y Leon, con pleno, y absoluto dominio. En la Imprenta de Antonio Marín. Madrid.

67 La obra citada con el título abreviado: Conde de la Cañada. Observaciones prácticas..., ha sido identificada como la obra: ${ }^{*} \mathrm{Ca}-$ ñada, Conde de la. 1793. Observaciones practicas sobre los recursos de fuerza: modo y forma de introducirlos, continuados, y determinados en los tribunales superiores. En la Imprenta Real. Madrid.

68 La obra citada con el título abreviado: Juan de Hevia Bolaños. Curia Philippica, ha sido identificada como la obra: "Hevia Bolaños, Juan de. 1609. Curia philippica, donde breve y comprehendiose se trata de la juyzios mayormente forenses, eclesiasticos y seculares, con lo sobre ellos hasta aora dispuesta por derecho resuleto por doctores antiguos y modernos, y practicable. Por Iuan Godinez de Millis. Valladolid. 
go Vascuñana y Montoya ${ }^{69}$-, obras de humanistas -Arnaldo Vinnio ${ }^{70}$-, de críticos al Derecho vigente en el siglo XVIII -Manuel de Lardiza$\mathrm{bal}^{71}$-, de instituciones de Derecho patrio o nacional -Santiago Magro y Zurita y Eusebio Ventura Beleña ${ }^{72}-$, y de prácticos del siglo

69 La obra citada con el título abreviado: Alfonso de Villadiego Vascuñana y Montoya. Instrucción política y práctica judicial, ha sido identificada como la obra: "Villadiego Vascuñana y Montoya, Alfonso de. 1612. Instrucción politica y practica iudicial: conforme al estilo de los consejos, audiencias, y tribunales de corte, y otros ordinarios del reyno... Luis Sánchez. Madrid.

70 La obra citada con el título abreviado: Arnaldo Vinnio. Institutionum imperialium commentarius academicus et forensis, ha sido identificada como la obra: *Vinnius, Arnoldus. 1699. In quatuor libros Institutionum imperalium Commentarius Academicis et Forensis Arnoldi Vinnii. Editio novissima et emendatissima. Sumptibus Anisson: et Ioannis Posuel. Lugduni, 2 volúmenes.

71 Tras consultar varios repertorios bibliográficos no ha sido posible identificar la obra citada bajo el título abreviado: Manuel de Lardizabal. Discurso sobre las penas.

72 Tras consultar varios repertorios bibliográficos no ha sido posible identificar la obra citada bajo el título abreviado: Santiago Magro y Zurita; Eusebio Ventura [o Buenaventura] Beleña. Elucidationes ad Quatuor Libros. 
XVIII -Fray Pedro Murillo Velarde, ${ }^{73}$ Manuel Silvestre Martínez, ${ }^{74}$ Francisco Antonio de Elizondo ${ }^{75}$.

2. Sebastián Calvo de la Puerta (1717-1767) Alcalde del Crimen de la Real Audiencia de México y Oidor de la Real Audiencia de Guatemala, poseía fuentes romanas -Corpus Iuris Civilis-, fuentes canónicas -Corpus Iuris Canonici-, textos de legislación real-Siete Partidas, ${ }^{76}$ Nueva Recopilación de Castilla, Recopilación de Indias, y Francisco

73 La obra citada con el título abreviado: Fray Pedro Murillo Velarde. Práctica de testamentos, ha sido identificada como la obra: *Murillo Velarde, Fray Pedro. 1755. Práctica de testamentos, en que se resuleven los casos mas frequentes, que se ofrecen en la disposicion de las ultimas voluntades. En la Impr. del Nuevo Rezado de los herederos de Doña María de Rivera. México.

74 La obra citada con el título abreviado: Manuel Silvestre Martínez. Librería de jueces, ha sido identificada como la obra: "Martínez, Manuel Silvestre. 1774. Librería de jueces, utilisima, y universal. Imprenta de Blas Roman. Madrid, 5 volúmenes.

75 La obra citada con el título abreviado: Elizondo, Francisco Antonio de. Práctica universal forense, ha sido identificada como la obra: *Elizondo, Francisco Antonio de. 1770. Práctica universal forense de los tribunales superiores de España, y de las Indias. $2^{a}$ impresion. Joachin Ibarra Impresor. Madrid.

76 La obra citada con el título abreviado: Siete Partidas, ha sido identificada como la obra: Las Siete partidas del Sabio Rey don Alonso el nono, nuevamente glosadas por el Licenciado Gregorio López del Consejo Real de Indias de Su Magestad. M.D.L.V. Por Andrea de Portonaris. Salamanca. 


\section{de Montemayor ${ }^{77}$-, obras de comentaristas de fuentes canónicas inscritos en el mos italicus tar- dío -Pedro Barbosa, ${ }^{78}$ y Anacleto Reiffens- tuel $^{79}-$, obras de comentaristas de Derecho real}

77 La obra citada con el título abreviado: Francisco de Montemayor. Sumario de las cédulas, órdenes y provisiones reales que se ban despachado por Su Majestad para la Nueva España y otras partes, ha sido identificada como la obra: ${ }^{*}$ Montemayor, Francisco de. [1678]. Summarios de las cedulas, ordenes, y provisiones reales, y otras partes; especialmente desde el año de mil seiscientos y veinte y ocho, en que se imprimieron los quatro libros, del primer tomo de la Recopilacion de Leyes de las Indias...: que juntó y dispuso el doctor Don Iuan Francisco de Montemayior, y Cordova de Cuenca. En la Imprenta de la Viuda de Bernardo Calderón. México.

78 La obra citada con el título abreviado: Francisco de Montemayor. Sumario de las cédulas, órdenes y provisiones reales que se ban despachado por Su Majestad para la Nueva España y otras partes, ha sido identificada como la obra: "Montemayor, Francisco de. [1678]. Summarios de las cedulas, ordenes, y provisiones reales, y otras partes; especialmente desde el año de mil seiscientos y veinte y ocho, en que se imprimieron los quatro libros, del primer tomo de la Recopilacion de Leyes de las Indias...: que juntó y dispuso el doctor Don Iuan Francisco de Montemayior, y Cordova de Cuenca. En la Imprenta de la Viuda de Bernardo Calderón. México.

79 La obra citada con el título abreviado: Anacleto Reiffenstuel. Ius canonicum universum clara methodo iuxta titulos quinque librorum Decretalium in quaestionum distributum, ha sido identificada como la obra: "Reiffenstuel, Anacleto. 1739. Ius Canonicum universum clara methodo iuxta titulos quinque Librorum decretalium in quaestiones $2^{a}$ ed. Joannis Andreae de la Haye. Ingolstadi. 
inscritos en el mos italicus tardío -Diego Pérez Salamanca, ${ }^{80}$ Gregorio López, ${ }^{81}$ Juan de Matienzo, ${ }^{82}$ Alfonso de Azevedo, ${ }^{83}$ Alfonso de Carbona,${ }^{84}$

80 La obra citada con el título abreviado: Diego Pérez de Salamanca. Commentaria in librum VIII Ordinationum Regni Castellae, ha sido identificada como la obra: "Pérez de Salamanca, Diego. 1574. Commentaria in quatuor posteriores libros ordinationum regni castellae. In aedibus Dominici a Portonariis, S.C.M. Typographi. Salmanticae.

81 La obra citada con el título abreviado: Gregorio López. Glosa a las Partidas, ha sido identificada como la obra: "Las Siete partidas del Sabio Rey don Alonso el nono, nuevamente glosadas por el Licenciado Gregorio López del Consejo Real de Indias de Su Magestad. M.D.L.V. Por Andrea de Portonaris. Salamanca.

82 La obra citada con el título abreviado: Juan de Matienzo. In librum V Collectionis Legum Hispaniae commentaria, ha sido identificada como la obra: "Matienzo, Juan de. 1597. Commentaria Ioannis Matienzo regii Senatoris in Cancellaria Argentina reggni Peru in librum quintum recollectiones legum Hispaniae. Excudebat Petrus Madrigal. Mantuae Carpentanee.

83 La obra citada con el título abreviado: Alfonso de Azevedo. Commentarium Iuris Civilis in Hispaniae Regias Constitutiones, ha sido identificada como la obra: *Azevedo, Alfonso de. 1583-1599. Commentarium Iuris Civilis in Hispaniae Regias Constitutiones. Excudebat Cornelius Bobardus. Salmanticae. 6 volúmenes.

84 La obra citada con el título abreviado: Alfonso de Narbona. Commentaria in tertiam partem Novae Recopilationis Legum Hispaniae, ha sido identificada como la obra: *Narbona, Alfonso de. 1624. Commentaria in tertiam partem Novae Recopilationis legum Hispaniae Alphonsi Narbona. Apud Didacum Rodriguez, Typ. Regium. Toleti. 
Francisco Carrasco del Saz, ${ }^{85}$ Santiago Magro y Zurita $^{86}$-, obras de consiliaristas inscritos en el mos italicus tardío -Alfonso de Azevedo, ${ }^{87}$ Próspero Farinacio, ${ }^{88}$ Juan Baustista Valenzuela Velásquez, ${ }^{89}$ y Diego Ibáñez de Faría ${ }^{90}-$,

85 La obra citada con el título abreviado: Francisco Carrasco del Saz. Interpretatio ad singulas Leges Novae Recopilationes Regni Castellae, ha sido identificada como la obra: *Carrasco del Saz, Francisco. 1620. Interpretatio ad aliquas recopilationis regni castellae. Apud Hieronimum A. Contreras. Hispali.

86 Tras consultar varios repertorios bibliográficos no ha sido posible identificar la obra citada bajo el título abreviado: Santiago Magro y Zurita. Indice de las proposiciones de las leyes de la Recopilación.

87 Tras consultar varios repertorios bibliográficos no ha sido posible identificar la obra citada bajo el título abreviado: Alfonso de Azevedo. Consilia iuris responsa.

88 La obra citada con el título abreviado: Próspero Farinacio. Consilia sive responsa atque decisionum causarum criminalium, ha sido identificada como la obra: "Farinacio [o Farinacci], Próspero. 1649. Consilia sive Responsa atque decisiones causarum criminalium. Excudebat Phillipus Gamonetus. Colonia Allobrogum.

89 La obra citada con el título abreviado: Juan Bautista Valenzuela Velázquez. Consiliorum sive responsorum iuris, ha sido identificada como la obra: "Valenzuela Velázquez, Juan Bautista. 1634. Consilia sive iuris responsa. [S.n.]. Neapoli, 2 volúmenes.

90 La obra citada con el título abreviado: Diego Ibáñez de Faría. Additiones, enucleationes et notae ad librum primum (secundum), ha sido identificada como la obra: "Ibáñez de Faría, Diego. 1675. Additiones, observationes et nota ad libros variarum resolutionum illustrissimi ac reverendissimi D. Didaci Covarruvias $A$ Leiva. [S.n.]. Lugduni. 
obras de decisionistas inscritos en el mos italicus tardío -Juan Bautista Larrea, ${ }^{91}$ Miguel Calderó, ${ }^{92}$ Luis Postio, ${ }^{93}$ Juan Bautista de Luca, ${ }^{94}$ Cristóbal Crespi de Valldaura y Parizuela, ${ }^{95}$ y Miguel

91 La obra citada con el título abreviado: Juan Bautista Larrea. Novae Decisiones Granatensis, ha sido identificada como la obra: *Larrea, Juan Bautista. 1647-1648. Novarum decisionum sacri regii Senatus granatensis, regni Castellae. Haered. Petri Prost, Phillippi Borde, \& Laurentii Arnaud. Turnoni, 2 volúmenes.

92 La obra citada con el título abreviado: Miguel Calderó. Sacri regii criminalis Cathaloniae decisiones, ha sido identificada como la obra: "Calderó, Miguel. 1686-1701. Sacri regii criminalis concili Cathaloniae decisiones: cum additionibus ad primam, et secundam partem, et duplici indice dicisionum additionum. Ex Typographia Raphaelis Figuero. Barcinonae, 3 volúmenes.

93 La obra citada con el título abreviado: Luis Postio. Decisiones Sacrae Rotae Bononiensis, ha sido identificada como la obra: "Postio, Luis [o Ludovici Postii]. 1697. Decisiones rotae bononiensis. De. novissima. Sumptibus J. A. Cramer \&: P. Perachon. Genevae.

94 La obra citada con el título abreviado: Juan Bautista de Luca. Sacrae Rotae Romanae Decisiones, ha sido identificada como la obra: *Luca, Cardenal Juan Baustista de. 1759. Sacrae rotae romanae Decisiones, et sumomorum pontificum constitutiones recentissimae, Theatrum verita et justitae. Ex typographia Balleoniana. Venetiis.

95 La obra citada con el título abreviado: Cristóbal Crespi de Valldaura y Parizuela. Observationes illustratas decisionibus sacri Supremi Aragorum Consiliis Cruciatae \& Regiae Audientiae Valentiae, ha sido identificada como la obra: "Crespi de Valldaura y Parizuela, Cristóbal. 1662. Observationes illustrata decisionibus sacri Supremi regii aragonum consilii supremi consilii sancta cruciata E regia audientia Valentina. Sumptibus Horatii Boissat \& Georgii nemeus. Lugduni, 2 volúmenes. 
Cortiada ${ }^{96}$-, obras de controversistas inscritos en el mos italicus tardío -Tomás Carlevalio, ${ }^{77}$ Juan del Castillo Sotomayor, ${ }^{98}$ y Diego Cantera ${ }^{99}$-, obras de alegacionistas inscritos en el mos italicus

96 La obra citada con el título abreviado: Miguel Cortiada. Decisiones Reverendi Cancellarii et Sacri Regii Senatus Catbaloniae, ha sido identificada como la obra: *Cortiada, Miguel. 1714. Decisiones cancellarii et sacri regii senatus cathaloniae. Sumptibus Anisson, \& Pasuel. Lugduni, 2 volúmenes.

97 La obra citada con el título abreviado: Tomás Carlevalio. Disputationum iuris variarum de iudiciis, ha sido identificada como la obra: *Carleval [o Carlevalio], Tomás. 1649. Disputationum iuris variarum ad interpretationem regiarum legum regni Castellae, et illis similium, tam ex iure neapolitano, quam ex utroque communi civili, et canonico. Apud Mariam Quignonii. Madriti, 2 tomos en 1 volumen.

98 La obra citada con el título abreviado: Juan del Castillo Sotomayor. Quotidianarum controversiarum iuris, ha sido identificada como la obra: *Castillo Sotomayor, Juan del. 1603. Quotidianarum controversiarum iuris liber primus...: in quo ususfructus singularis ettutilis tractatus continetur... Ex officina Ioannis Gratiani apud viduam: a costa de Diego Guillén... Compluti.

99 La obra citada con el título abreviado: Diego Cantera. Quaestiones criminales, ha sido identificada como la obra: *Cantera, Diego. 1589. Quaestiones criminales tangentes iudicem accusatorem, reum, probationem, punitionem que delictorum.: Excudebat Cornelius Bonardus. Salmanticae. 
tardío -Diego Antonio Yáñez Fajardo, ${ }^{100}$ Pedro Diez de Rivadeneyra, ${ }^{101}$ y Juan Bautista Larrea $^{102}$, obras de tratadistas inscritos en el mos italicus tardío -Cristóbal de $\mathrm{Paz},{ }^{103}$ Antonio

100 La obra citada con el título abreviado: Diego Antonio Yánez Fajardo. Iuris allegationum Fiscalium Mediolani in gravibus causis semicenturiam bipartitam, ha sido identificada como la obra: *Yáñez Fajardo, Diego Antonio. 1671. Iuris allegationum fiscalium mediolani in gravibus causis. Semicenturia bipartita, cui accessu Tractatus de Legimationi per subsequens matrimonium, $\mathcal{E}$ singularis quaestio regularis. Sumpt. Arnaud: et Petri Borde. Lugduni, 2 volúmenes.

101 La obra citada con el título abreviado: Pedro Diez de Rivadeneyra Nogueral. Allegationum iuris, ha sido identificada como la obra: "Diez de Rivadeneyra Nogueral, Pedro. 1656. Allegationum iuris: in quibus quam plures quaestiones summe necessariae in supremae Hispaniarum Curiae tribunalibus disceptatae ad praxim us umque forensem spectantes enuncleantur: opus novum...; cum duplici indice... Ex Typographia Regia: a Costa de Manuel Lopez mercader de libros. Matriti.

102 La obra citada con el título abreviado: Juan Bautista Larrea. Allegationes fiscales, ha sido identificada como la obra: "Larrea, Juan Bautista. 1642. Allegationum fiscalium. Sumptibus Petri Prost. Lugduni, 2 volúmenes.

103 Tras consultar varios repertorios bibliográficos no ha sido posible identificar la obra citada bajo el título abreviado: Paz, Cristóbal de. De maioratibus, et eorum tenuta, seu interdicto et remedio possessorio. 


\section{Ayerve de Ayora, ${ }^{104}$ Marco Antonio Peregri- no, ${ }^{105}$ Alfonso Guzmán Genzor, ${ }^{106}$ Sebastián Vantius, ${ }^{107}$ José Mascardo, ${ }^{108}$ Juan Vela de}

104 La obra citada con el título abreviado: Antonio Ayerve de Ayora. De bonorum partitionibus tractatum, ha sido identificada como la obra: *Ayerve de Ayora, Antonio. 1677. Tractatus de partitionibus bonorum communium inter conjuges, parentes et $l i$ beros eorumque haeredes in quator partes distinctus recognitus y locupletatus: in quarum singulis etiam permulfa de fructibus haereditatum... traduntu ... Sumptibus Joannis-Antonii Huguetan y Soc. Lugduni.

105 La obra citada con el título abreviado:Antonio Peregrino. De iuribus et privilegiis fisci, ha sido identificada como la obra: "Peregrino, Marco Antonio. 1587. De iuribus et privilegiis fisci... Apud Paulum Meietum Bibliopolam Pataninum. Venetiis.

106 La obra citada con el título abreviado: Alfonso Guzmán Genzor. Tractatus de evictionibus, ha sido identificada como la obra: *Guzmán Genzor, Alfonso. 1629. Tractatus de evictionibus. Omnibus quidem iuri operam damtibus, tam in theorica, quàm in praxi perutilis, et non munùs iudicibus, quàm advocatis valdè neccesarius. In quo... Apud viduam Ildephonsi Martin. Matriti.

107 La obra citada con el título abreviado:Sebastián Vantius. Tractatus de nullitatibus processum $\mathcal{E}$ sententiarum, ha sido identificada como la obra: *Vantius, Sebastián. 1585. Tractatus de nullitatibus processuum ac sententiarum. In Officina Q. Philippi Tingli: Apud sinphonianum Beraud et Stephanum Michalini. Lugduni.

108 La obra citada con el título abreviado: José Marcardo. Conclusionum omnium probationum, ha sido identificada como la obra: "Mascardo, José [o Giuseppe Mascardi]. 1597. Conclusiones omnium probationum, ac quaestionum, quae in utroque foro quotidie versantur... [S.n.]. Augustae Tourinoram, 2 volúmenes. 
De los libros surgen las leyes. Aproximación a los fondos ...

\section{Acuña, ${ }^{109}$ Jacobo Menochius, ${ }^{110}$ Segismundo}

109 La obra citada con el título abreviado: Juan Vela de Acuña. Tractatus de poenis delictorum, ha sido identificada como la obra: *Vela de Acuña, Juan. 1596. Tractatus de poenis delictorum... Prima editio. Excudebat Didacus a Cussio: Expensis Martini Perez. Salmanticae.

110 La obra citada con el título abreviado: Jacobo Menochius. De praesumptionibus, coniecturis, signis et indiciis, commentaria, ha sido identificada como la obra: "Menochius, Jacobo [Giacomo Menochio]. 1587-1590. De praesumptionibus coniecturis, signis, et indiciis, commentariorum pars prima (secunda): adjecta sunt summaria indexque, omnium rerum sententiarumque, in signium locupletissimus. Ex officina F. de Franciscis. Venetiis, 2 vol. La obra citada con el título abreviado: Jacobo Menochius. De adipiscenda possessione, retinenda et recuperanda amplissimi et doctissimi commentarii, ha sido identificada como la obra: "Menochius, Jacobo [Giacomo Menochio]. 1605. De adipiscenda, retinenda et recuperanda possesione, doctissima commentaria Iacobi Menochii. Ex Officina Antonii Hierati. Colonia Agrippina. La obra citada con el título abreviado: Jacobo Menochius. De arbitrariis indicicum quaestionibus et causis centuriae sex, ha sido identificada como la obra: "Menochius, Jacobo [Giacomo Menochio]. 1630. De arbitrariis iudicicum quaestionibus et causis, centuriae sex, quibus tota iuris pars quae iudicum arbitrio $\mathcal{E}$ potestate pendet. Apud Philippum Albertu. Coloniae Allobrogum. 


\section{Scaccia ${ }^{111}$ Francisco Muñoz de Escobar, ${ }^{112}$ Alfonso de Olea, ${ }^{113}$ Manuel Román Valerón, ${ }^{114}$}

111 La obra citada con el título abreviado: Segismundo Scaccia. Tractatus de commercio et cambio, ha sido identificada como la obra: *Scaccia, Segismundo. 1620. Tractatus de commerciis, et cambio. Sumptibus Antonii Boëtzeri. Coloniae. La obra citada con el título abreviado: Segismundo Scaccia. Tractatus de sententia et re iudicata, ha sido identificada como la obra: "Scaccia, Segismundo. 1618. Tractatus, de iudiciis causarum civilium, criminalium, et haereticalium. Haeredum palthenianarum, ex Officina H. Palthenii. Francofurti. La obra citada con el título abreviado: Segismundo Scaccia. Tractatus de appellationibus, ha sido identificada como la obra: "Scaccia, Segismundo. 1628. Tractatus de sententia, et re iudicata. Ex officina Rovilliana: sumptibus Andreae: Iacobi \& Matthaei Prost. Lugduni.

112 La obra citada con el título abreviado: Francisco Muñoz de Escobar. De ratiociniis administratorum $\mathcal{E}$ aliis variis computationibus, ha sido identificada como la obra: "Muñoz de Escobar, Francisco. 1682. De ratiociniis administratorum et computationibus variis aliis: tractatus praegnatissimus. Wolffgangum Mauritium et Johannis Andreae. Noribergae.

113 La obra citada con el título abreviado: Alfonso de Olea. Tractatus de cessione iurium et actionum, ha sido identificada como la obra: *Olea, Alfonso de. 1752. Tractatus de cessione iurium et actionum: in quo insertae sunt suo loco, additiones seu resolutiones, cum sacrae Rotae romanae decisionibus ad hancce materiam facientibus. Typographia Balleoniana. Venetiis.

114 Tras consultar varios repertorios bibliográficos no ha sido posible identificar la obra citada bajo el título abreviado: Román Valerón, Manuel. De transactionibus tractatum. 


\section{Luis Postio, ${ }^{115}$ Hermenegildo de Roxas, ${ }^{116}$ Domingo Antúnez Portugal, ${ }^{117}$ Lorenzo Matheu y Sanz, ${ }^{18}$}

115 La obra citada con el título abreviado: Luis Postio. Tractatus de subhastatione, ha sido identificada como la obra: "Postio, Luis. 1652. De subhastatione: tractatus non superfluus, sed necessarius, $\mathcal{E}$ ad praxim aptatus, E ordinatus. Sumptibus Iohannis de Tournes. Genevae. La obra citada con el título abreviado: Luis Postio. Tractatus mandati de manutendo, ha sido identificada como la obra: "Postio, Luis. 1674. Sacrotae romanas decisiones ad tractarum mandati de manu tenendo. Ex Typographia' Marthael i Liberal, et Simonis Potin. Lyon.

116 La obra citada con el título abreviado: Hermenegildo de Roxas. Tractatus posthumus de incompatibilitate regnorum ac maioratum, ha sido identificada como la obra: *Aguila y Roxas, Fernando Alfonso del. 1738. Additae quaestiones de incompatibilitate regnorum \& maioratuum, ad Tractatum d. Hermenegildi de Roxa ... quem in lucem editum vidit curâ E studio d. Francisci Ximenes del Aguila... ubi plura utilissima et noviter discursa in materia resolvuntur, E decisionibus tribunalium Hispaniae, maximè Granatensis senatus, comprobata, ad praxim utiliter inveniuntur. Sumptibus fratrum de Tournes. Coloniae Allobrogum.

117 Tras consultar varios repertorios bibliográficos no ha sido posible identificar la obra citada bajo el título abreviado: Domingo Antúnez de Portugal. De donationibus iurium et bonorum Regiae Coronae.

118 La obra citada con el título abreviado: Lorenzo Matheu y Sanz. Tractatus de re criminali, ha sido identificada como la obra: *Matheu y Sanz, Lorenzo. 1672. Tractatus de re criminali, sive controversiarum usufrequentium in causis Criminalibus, cum earum decissionibus, tàm in Aula suprema ac Hispana Criminum, quàm in summo senatu novi orbis. Editio tertia prioribus emendatior cum triplici indice controversiarum, jurium ac rerum locupletissimo. Sumptibus Anisson. Lugduni. 
Blas Ultimar, ${ }^{119}$ Melchor Meres, ${ }^{120}$ Ansaldo de
Ansaldis, ${ }^{121}$ Lorenzo María de Casaregis, ${ }^{122}$
Agustín Barbosa, ${ }^{123}$ Francisco Alfaro, ${ }^{124}$ Blas

119 La obra citada con el título abreviado: Blas Altimar. Tractatus de nullitatibus sententiarum, ha sido identificada como la obra: *Altimari, Blas. 1704. Tractatus de nullitatibus contractuum, quasi contractuum, distractuum, utimarum voluntatum $\varepsilon$ quorumcumque, actuum extraiudicilium D. Blasii Altimari. Apud Paulum Balleonium. Venetiis.

120 Tras consultar varios repertorios bibliográficos no ha sido posible identificar la obra citada bajo el título abreviado: Melchor Meres. De maioratus et meliorationibus Hispaniae.

121 Tras consultar varios repertorios bibliográficos no ha sido posible identificar la obra citada bajo el título abreviado: Ansaldo de Ansaldis. De commencio et mercatura discursus legales.

122 Tras consultar varios repertorios bibliográficos no ha sido posible identificar la obra citada bajo el título abreviado: Lorenzo María de Casaregis. De commercio et mercatura discursus legales.

123 La obra citada con el título abreviado:Agustín Barbosa. Opera, ha sido identificada como la obra: "Barbosa, Agustín. 1699. Opera Agustini Barbosae. Ed. novissima, ab authore recognita. Sumptibus Petri Borde, Joannis et Petri Arnaud. Lugduni.

124 La obra citada con el título abreviado: Francisco Alfaro. Tractatus de officio fiscalis deque fiscalibus privilegiis, ha sido identificada como la obra: *Alfaro, Francisco de. 1606. Tractatus de officio fiscalis, deque fiscalibus privilegiis. Apud Ludovicum Sanchez. Vallisoleti. 
Robles de Salcedo, 125 Gaspar de Escalona y Agüero, ${ }^{126}$ Juan de Solórzano Pereira, ${ }^{127}$ Matías Lagúnez, ${ }^{128}$ Francisco Salgado de Somoza, ${ }^{129}$

125 La obra citada con el título abreviado: Blas Robles de Salcedo. Novus et methodicus tractatus de repraesentatione, ha sido identificada como la obra: *Robles Salzedo, Blasius. 1624. Novus et methodicus tractatus de representatione in tres libros divisus: opus sane tam in scholes quam in foro versantibus perutile et necessarium. Apud Joannem Gonçalez. Matriti.

126 Tras consultar varios repertorios bibliográficos no ha sido posible identificar la obra citada bajo el título abreviado: Gaspar de Escalona y Agüero. Arcae Limensis.

127 La obra citada con el título abreviado: Juan de Solórzano Pereira. Política Indiana, ha sido identificada como la obra: *Solórzano Pereira, Juan de. 1647. Política Indiana. $1^{\text {a }} \mathrm{Ed}$. Madrid: Officina de Diego Diaz de la Carrera. Madrid.

128 La obra citada con el título abreviado: Matías Lagúnez. Tractatus de fructibus, ha sido identificada como la obra: Lagunez, Matías. 1686. Tractatus de fructibus: titulo generali in quo selectiora, qua rem fructuariam pertinens iura expendutur difficilioraque referantur. Ex Typographia Melchioris Alvarez. Matriti, 2 volúmenes.

129 La obra citada con el título abreviado: Francisco Salgado de Somoza. De regia protectione, ha sido identificada como la obra *Salgado de Somoza Francisco. 1626. Tractatus de regia protectione vi oppressorum appellantium à causis $\mathcal{E}$ iudicibus ecclesiasticis. Sumpt. L. Prost., haeredis Roville. Lugduni, 2 volúmenes. La obra citada con el título abreviado: Francisco Salgado de Somoza. Tractatus de supplicatione ad Sanctissimum, ha sido identificada como la obra: *Salgado de Somoza, Francisco. 1664. Tractatus de supplicatione ac Sanctissimum Aliteris et de earum retentione intermin senatu. $1^{a}$ ed. Sumptibus Lartentii Anissan. Lyancase. La obra citada con el título abreviado: Francisco Salgado de Somoza. Labyrinthus creditorum, ha sido identificada como la obra: "Salgado de Somoza, Francisco. 1653. Labyrintbus creditorum concurrentium ad litem per debitorem communem inter illos causatam. Apud Iacobum Meursium. Antuerpiae, 2 volúmenes. 
Gaspar de Villarroel, ${ }^{130}$ Pedro Frasso, ${ }^{131}$ y Antonio José Álvarez de Abreu ${ }^{132}$-, obras de prácticos inscritos en el mos italicus tardío -Luis Carrera, ${ }^{133}$ Ignacio López de Salcedo, ${ }^{134}$

130 La obra citada con el título abreviado: Gaspar de Villarroel. Gobierno eclesiástico pacífico y..., ha sido identificada como la obra: *Villarroel, Gaspar de. 1656. Gobierno Eclesiástico Pacífico y Unión de los dos Cucbillos, Pontificio y Regio. Domingo García Morás. Madrid, 2 volúmenes.

131 La obra citada con el título abreviado: Pedro Frasso. De regio patronatu, ha sido identificada como la obra: "Frasso, Pedro. 1677-1679. De regio patronatu: ac aliis nonnullis regaliis, regibus catholicis, in Indiarum Occidentalium Imperio, pertinentibus, quaestiones aliquae desumptae, et disputatae. In quinquaginta capita partitae. Ex Typographia Imperiali: apud Iosephum Fernandez á Buendia. Matriti, 2 tomos en 3 volúmenes.

$132 \mathrm{La}$ obra citada con el título abreviado: Antonio Álvarez de Abreu. Víctima real legal..., ha sido identificada como la obra: *Álavarez de Abreu, Antonio José. 1726. Víctima Real legal, discurso único jurídico-histórico-político sobre que las vacantes mayores y menores de las Iglesias de las Indias Occidentales, pertenecen a la corona de Castilla y León, en pleno, y absoluto dominio. En la Imprenta de Antonio Marin. Madrid.

133 Tras consultar varios repertorios bibliográficos no ha sido posible identificar la obra citada bajo el título abreviado: Luis Carrera. Practica causarum criminalium.

134 La obra citada con el título abreviado: Ignacio López de Salcedo. Singularis et excellentissima practica criminalis canonica, ha sido identificada como la obra: "López de Salcedo, Ignacio. 1594. Singularis et excellantisima practica criminalis canonica: excommunicationis, irregularitas... Apud haeredes Ioannis Gratiani. Compluti. 
Gabriel Parexa de Quesada, ${ }^{135}$ Julio Claro, ${ }^{136}$ Gonzalo Suárez de Paz ${ }^{137}$ Juan de Hevia Bola ños, ${ }^{138}$ y Gómez Bayo ${ }^{139}$-, obras de la Escuela

135 La obra citada con el título abreviado: Gabriel Parexa de Quesada. Praxis de instrumentorum editione, ha sido identificada como la obra: "Pareja y Quesada, Gabriel. 1668. Praxis edendi, sive tractatus de universa instrumentorum editione. Editione novissima. Sumptibus Laurentii Anisson. Lugduni, 2 tomos en 1 volumen.

136 La obra citada con el título abreviado:Julio Claro. Practica civilis et criminalis, ha sido identificada como la obra: "Claro, Giulio. 1661. Inlii Clario pera omnia, sive practica civilis atque criminalis. Sumpt. Horatii Boissat \& Georgii Remei. Lugduni.

137 La obra citada con el título abreviado: Gonzalo Suárez de Paz. Praxis ecclesiastica et saecularis, ha sido identificada como la obra: *Suárez de Paz, Gonzalo. 1597. Praxis ecclesiasticae et secularis: cum actionum formulis $\mathcal{E}$ actis processum. Methymma I a Campo excudebat Iacobus a Canto, [Matriti], 3 tomos en 1 volumen.

138 La obra citada con el título abreviado: Juan de Hevia Bolaños. Curia Philippica, ha sido identificada como la obra: "Hevia Bolaños, Juan de. 1609. Curia philippica, donde breve y comprehendiosamente se trata de los juyzios mayormente forenses, eclesiasticos y seculares, con lo sobre ellos hasta aora dispuesta por derecho resuelto por doctores antiguos y modernos, y practicable. Por Juan Godinez de Milli. Valladolid.

139 La obra citada con el título abreviado: Gómez Bayo. Praxis ecclesiastica et saecularis, ha sido identificada como la obra: *Bayo, Gómez. 1640 (1639). Praxís ecclesiastica et secularis: cartineus tres libros: primum de praxi, secundum de questionibus veriis, testium de collectanea doctorum... Vallisoleti: ex officina Mieronimi Murillo..: expensis Andreae Calderon viduae Bibliopolae. Vallisoleti. 
española de Derecho natural -Luis de Moli$\mathrm{na}^{140}$, , obras de humanistas -Francisco Amaya ${ }^{141}$-, de políticos del siglo XVIII -Carlos Montesquieu, ${ }^{142}$ y Observations sur l'Esprit des Lois ${ }^{143}$ - y de prácticos del siglo XVIII -José Manuel Domínguez Vicente ${ }^{144}-$.

140 La obra citada con el título abreviado: Luis de Molina. De iustitia et iure, ha sido identificada como la obra: "Molina, Luis de. 1614. De Institia et iure. R. P. Lodovici Molina. Excudebat Balthasar Lippius. Moguntia.

141 La obra citada con el título abreviado: Francisco Amaya. Observationum iuris libri tres, ha sido identificada como la obra: *Amaya, Francisco de. 1625. Observationum Iuris: libri tres. Excudebat Antonia Ramirez. Salmanticae.

142 La obra citada con el título abreviado: Carlos Montesquieu. L'Esprit des Lois, ha sido identificada como la obra: "Montesquieu, Carlos de Secondant Baron de la Brède et de. 1750. De $L$ 'esprit des loix: Ou du rapport que les loix doivent avoir avec la Constitution de chaque Gouvernement... Nouvelle edition / corrigée par l'auteur, E augmentee d'une table, Ed d'une Carte Geograbique. Chez Barrillot \& Fils. Geneve.

143 Tras consultar varios repertorios bibliográficos no ha sido posible identificar la obra citada bajo el título abreviado: Observations sur l'Esprit des Lois.

144La obra citada con el título abreviado: José Manuel Domínguez Vicente. Ilustración y continuación de la Curia Filípica, ha sido identificada como la obra: *Domínguez Vicente, José Manuel. 1736. Ilustración y continuación a la Curia Philípica, y corrección de las citas que en ella se hallan cerradas: dividido en las mismas cinco partes: trátase del modo de proceder en los juicios eclesiásticos, y seculares, con lo que sobre ello ay hasta aora dispuesto por derecho resulto por doctores antiguos, y modernos. En la Oficina de los Herederos de Juan García Infanzón. Madrid. 2 volúmenes. 
De los libros surgen las leyes. Aproximación a los fondos ...

3. Fray Francisco de la Cuesta (16?-1723) Arzobispo de Manila y Obispo electo de Michoacán, ${ }^{145}$ poseía textos de legislación real-Recopilación de Indias-, obras de tratadistas inscritos en el mos italicus tardío -Juan de Solórzano Pereira, ${ }^{146}$ y Gaspar de Villarroel ${ }^{147}$ - y obras de prácticos inscritos en el mos italicus tardío -Gonzalo Suárez de $\mathrm{Paz}^{148}$.

4. Doctor Manuel Ignacio González del Campillo (1740-1813), Obispo de Puebla, poseía fuentes canónicas -Corpus Iuris Canonici, Concilio Tridenti-

145 El contenido jurídico de la biblioteca de este prelado no es rico, sin embargo he decidido incluirlo debido al escaso número de datos que se conocen en relación a las bibliotecas formadas en la Gobernación y Capitanía General de las islas Filipinas.

146 La obra citada con el título abreviado: Juan de Solórzano Pereira. Politica Indiana, ha sido identificada como la obra: "Solórzano Pereira, Juan de. 1647. Política Indiana. $1^{a}$ Ed. Officina de Diego Diaz de la Carrera. Madrid.

147 La obra citada con el título abreviado: Gaspar de Villarroel. Gobierno eclesiástico pacífico y..., ha sido identificada como la obra: *Villarroel, Gaspar de. 1656. Gobierno Eclesiástico Pacífico y Unión de los dos Cuchillos, Pontificio y Regio. Domingo García Morás. Madrid, 2 volúmenes.

148 La obra citada con el título abreviado: Gonzalo Suárez de Paz. Praxis ecclesiastica et saecularis, ha sido identificada como la obra: *Suárez de Paz, Gonzalo. 1597. Praxis ecclesiasticae et secularis: cum actionum formulis $\mathcal{E}$ actis processum. Methymma I a Campo excudebat Iacobus a Canto. [Matriti], 3 tomos en 1 volumen. 
no, Tercer Concilio Mexicano-, textos de legislación real -Siete Partidas, ${ }^{149}$ Ordenanzas Reales de Castilla, Nueva Recopilación de Castilla, Recopilación de Indias, Ordenanzas de Intendentes, y Eusebio Ventura Beleña ${ }^{150}$, obras de comentaristas de fuentes canónicas inscritos en el mos italicus tardío -Manuel González Téllez, ${ }^{151}$ Próspero Fagnanus, ${ }^{152}$

149 La obra citada con el título abreviado: Siete Partidas, ha sido identificada como la obra: *Las Siete partidas del Sabio Rey don Alonso el nono, nuevamente glosadas por el Licenciado Gregorio López del Consejo Real de Indias de Su Magestad. M.D.L.V. Por Andrea de Portonaris. Salamanca.

150 La obra citada con el título abreviado: Eusebio Ventura [o Buenaventura] Beleña. Recopilación sumaria de todos los autos acordados de la Real Audiencia y Sala del Crimen de esta Nueva España, ha sido identificada como la obra: *Beleña, Eusebio Ventura [o Buenaventura]. 1787. Recopilación sumaria de todos los autos acordados de la Real Audiencia y Sala del Crimen de esta Nueva España. F. de Zúñiga y Ontiveros. México, 2 volúmenes.

151 La obra citada con el título abreviado: Manuel González Téllez. Commentaria perpetua in singulos textus quinque librorum Decretalium, ha sido identificada como la obra: *González Téllez, Manuel. 1673. Commentaria perpetua in singulos textus quinque librorum Decretalium Gregorii IX. Sumptibus Laurentii Arnaud, \& Petri Borde. Lugduni.

152 Tras consultar varios repertorios bibliográficos no ha sido posible identificar la obra citada bajo el título abreviado: Próspero Fagnanus. Commentaria in quinque libros Decretalium. 


\section{Anacleto Reiffenstuel, ${ }^{153}$ Claudio Fleury, ${ }^{154}$ Ze- ger Bernardo Van Espen, ${ }^{155}$ Juan Nicolás Hont- heim, ${ }^{156}$ Carlos Sebastián Berardi, ${ }^{157}$ Fray Pedro}

153 La obra citada con el título abreviado: Anacleto Reiffenstuel. Ius Canonicum universum clara methodo iuxta titulos quinque librorum Decretalium in quaestionum distributum, ha sido identificada como la obra: *Reiffenstuel, Anacleto. 1739. Ius Canonicum universum clara methodo iuxta titulos quinque Librorum decretalium in quaestiones $2^{a}$ ed. Joannis Andreae de la Haye. Ingolstadi.

154 La obra citada con el título abreviado: Claudio Fleury. Institution au droit eclesiastique, ha sido identificada como la obra: *Fleury, Claude. 1762-1763. Institution au droit ecclesiastique Nouv. ed., rev. E augm. de notes considerables $\mathcal{E}$ de deux tables ... par M. Boucher d'Argis. Chez Jean Thomas Herissant. A Paris, 2 volúmenes.

155 Tras consultar varios repertorios bibliográficos no ha sido posible identificar la obra citada bajo el título abreviado: Zeger Bernardo Van Espen. Ius Canonicum universum clara methodo iuxta titulos quinque librorum Decretalium in quaestionem distributum.

156 Tras consultar varios repertorios bibliográficos no ha sido posible identificar la obra citada bajo el título abreviado: Juan Nicolás [Justino Febronio] Hontheim. De statu ecclesiae deque legitima potestate romani Pontificis liber singularis ad reuniendos dissidentes in religione constitutus.

157 La obra citada con el título abreviado: Carlos Sebastián Berardi. Institutionum iuris ecclesiastici, ha sido identificada como la obra: *Berardi, Carlos Sebastiano. 1774. Institutiones iuris ecclesiastici: opus posthumum in duas partes tributum. Ex typographia D. Antonii de Sancha. Matriti, 2 tomos en 1 volumen. 
Murillo Velarde, ${ }^{158}$ Julio Lorenzo Selvagio, ${ }^{159}$ Jerónimo González, ${ }^{160}$ Juan Luis López ${ }^{161}$-, obras de comentaristas de Derecho real inscritos en el mos italicus tardío -Cristóbal de

158 La obra citada con el título abreviado: Fray Pedro Murillo Velarde. Cursus Iuris Canonici Hispani et Indici, ha sido identificada como la obra: "Murillo Velarde, Fray Pedro. 1743. Cursus iuris Canonici, hispani, et indici in quo iuxta ordinem titulorum decretalium non solum canonica Decissiones afferuntur, sed in super additur, quod in nostro Hispania Regno, $\mathcal{E}$ in his Indiarum Provinciis Lege, consuetudine, privilegio, vel praxi statutum, $\mathcal{E}$ admissum est: opus sanè utile iuris studiosis ... Ex Typographia Emmanuelis Fernandez. Matriti, 2 volúmenes.

159 La obra citada con el título abreviado: Julio Lorenzo Selvagio. Institutionum Canonicarum, ha sido identificada como la obra: *Selvagio, Giulio Lorenzo. 1784. Institutionum canonicarum libri tres ad usum seminerii neapolitani. De. nova matritensis ceteris nevera correctior. Apud Placidum Barco Lopez. [Matriti], 3 volúmenes.

160 Tras consultar varios repertorios bibliográficos no ha sido posible identificar la obra citada bajo el título abreviado: Julio González. Glossema ad Regulam VIII Cancellariae Apostolicae.

161 La obra citada con el título abreviado: Juan Luis López. Historia legal de la Bula llamada In Caena Domini, ha sido identificada como la obra: *López, Juan Luis. 1768. Historia legal de la Bula llamada In Coena Domini, dividida en tres partes: en que se refieren, su aumento, y su estado... desde el año de 1254 hasta el presente de 1698. [S.n.]. Madrid. 
Paz, ${ }^{162}$ Francisco de Avilés, ${ }^{163}$ Gregorio Ló-
pez, ${ }^{164}$ Antonio Gómez, ${ }^{165}$ Juan de Matienzo, ${ }^{166}$

162 La obra citada con el título abreviado: Cristóbal de Paz. Scholia ad Leges Regias Styli, ha sido identificada como la obra: *Paz, Christophoro de. 1608. Scholia ad leges regias styli. Apud Alphonsum Martinum Typographum. Madriti.

163 La obra citada con el título abreviado: Francisco de Avilés. Nova diligens ac perutilis expositio seu legum praetorum ac indicum syndicatus totius Hispaniae Regni, ha sido identificada como la obra: *Avilés, Francisco de. 1581. Nova, diligens ac perutilis expositio capitum, seu legum praetorum, ac Iudicum sindicatus regnitotius hispaniae. Ex Officina Ildefonsi á Terranova \& Neyla. Salmanticae.

164 La obra citada con el título abreviado: Gregorio López, ha sido identificada como: "Las Siete partidas del Sabio Rey don Alonso el nono, nuevamente glosadas por el Licenciado Gregorio López del Consejo Real de Indias de Su Magestad. M.D.L.V. Por Andrea de Portonaris. Salamanca.

165 Tras consultar varios repertorios bibliográficos no ha sido posible identificar la obra citada bajo el título abreviado: Gómez, Antonio. Commentarium absolutissimum ad Legum Tauri.

166 La obra citada con el título abreviado: Juan de Matienzo. In librum V Collectionis Legum Hispaniae commentaria, ha sido identificada como la obra: *Matienzo, Juan de. 1597. Commentaria Ioannis Matienzo regii Senatoris in Cancellaria Argentina reggni Peru in librum quintum recollectiones legum Hispaniae. Excudebat Petrus Madrigal. Mantuae Carpentanee. 
Alfonso de Carbona, ${ }^{167}$ Francisco Carrasco del Saz, ${ }^{168}$ Gaspar de Hermosilla, ${ }^{169}$ y Francisco Javier Gamboa ${ }^{170}$-, obras de consiliaristas inscritos en el mos italicus tardío -Juan Bautista Valenzuela Velásquez, ${ }^{171}$ y Diego Ibáñez de

167 La obra citada con el título abreviado: Alfonso de Narbona. Commentaria in tertiam partem Novae Recopilationis Legum Hispaniae, ha sido identificada como la obra: *Narbona, Alfonso de. 1624. Commentaria in tertiam partem Novae Recopilationis legum Hispaniae Alphonsi Narbona. Apud Didacum Rodriguez, Typ. Regium. Toleti.

168 La obra citada con el título abreviado: Francisco Carrasco del Saz. Interpretatio as singulas Leges Novae Recopilationes Regni Castellae, ha sido identificada como la obra: "Carrasco del Saz, Francisco. 1620. Interpretatio ad aliquas recopilationis regni castellae. Apud Hieronimum A. Contreras. Hispali.

169 La obra citada con el título abreviado: Gaspar de Hermosilla. Notae, additiones et resolutiones ad glossas Legum Partitarum D. Gregorii Lopetii, ha sido identificada como la obra: "Hermosilla, Gaspar de. 1674. Nota, additiones et resolutiones ad glossas legum partitarum D. Gregorii Lopetii. Ex officina Anissoniana. Lugduni, 2 volúmenes.

170 La obra citada con el título abreviado: Francisco Javier Gamboa. Comentarios a las Ordenanzas de Minas, ha sido identificada como la obra: *Gamboa, Francisco Xavier de. 1761. Comentarios a las ordenanzas de minas. [S.n.]. Madrid.

171 La obra citada con el título abreviado: Juan Bautista Valenzuela Velázquez. Consiliorum sive responsorum iuris, ha sido identificada como la obra: *Valenzuela Velázquez, Juan Bautista. 1634. Consilia sive iuris responsa. [S.n.]. Neapoli, 2 volúmenes. 
Faría $^{172}$-, obras de decisionistas inscritos en el mos italicus tardío -Juan Pedro Fontanella, ${ }^{173}$ Héctor Capicio Latro, ${ }^{174}$ Vicente de Francis, ${ }^{175}$ Mario Giurba, ${ }^{176}$ Juan Bautista de Luca, ${ }^{177}$

172 La obra citada con el título abreviado: Diego Ibáñez de Faría. Additiones, enucleationes et notae ad librum primum (secundum) ..., ha sido identificada como la obra: *Ibáñez de Faría, Diego. 1675. Additiones, observationes et nota ad libros variarum resolutionum illustrissimi ac reverendissimi D. Didaci Covarruvias A Leiva. [S.n.]. Lugduni, 1675.

173 La obra citada con el título abreviado: Juan Pedro Fontanella. Sacri Senatus Cataloniae decisiones, ha sido identificada como la obra: "Fontanella, Juan Pedro. 1639-1645. Sacri Regii Senatus Cathalonia decisiones. Ex Praelo, acaese Petri Lacavalleria. Barcinone, 2 volúmenes.

174 Tras consultar varios repertorios bibliográficos no ha sido posible identificar la obra citada bajo el título abreviado Héctor Capicio Latro. Decisiones novas Sacri Regii Consilii Neapolitani.

175 La obra citada con el título abreviado: Vicente de Franchis. Corpus decisionum Sacri Regii Consilium Neapolitani, ha sido identificada como la obra: "Franchis, Vicentius de. 1594. Decisionum sacri Regii Consilii Neapolitani. Apud Iuntas. Venetiis, 2 tomos en 1 volumen.

176 La obra citada con el título abreviado: Mario Giurba. Observationes et decisiones Tribunalium Siciliae, ha sido identificada como la obra: "Giurba, Mario. 1652. Tribunalium sicilia decisa observationes. Ex typographeo Ioannis Blaeu. Amsteladami.

177 La obra citada con el título abreviado: Juan Bautista de Luca. Rotae Romanae Decisiones, ha sido identificada como la obra: "Luca, Cardenal Juan Baustista de. 1759. Sacrae rotae romanae Decisiones, et sumomorum pontificum constitutiones recentissimae, Theatrum verita et justitae. Ex typographia Balleoniana. Venetiis. 
Cristóbal Crespi de Valldaura y Parizuela, ${ }^{178}$ y Miguel Cortiada ${ }^{179}$-, obras de controversistas inscritos en el mos italicus tardío -Francisco Merlino Pignatello, ${ }^{180}$ José Yáñez Parladorio, ${ }^{181}$

178 La obra citada con el título abreviado: Cristóbal Crespi de Valdaura. Observationes illustratas decisionibus Sacri Supremi Aragonum Consiliis. Cruciatae E Regiae Audientiae Valentiae, ha sido identificada como la obra: *Crespi de Valldaura y Parizuela, Cristóbal. 1662. Observationes illustrata decisionibus sacri Supremi regii aragonum consilii supremi consilii sancta cruciata $E$ regia audientia Valentina. Sumptibus Horatii Boissat \& Georgii nemeus. Lugduni, 2 volúmenes.

179 La obra citada con el título abreviado: Miguel Cortiada. Decisiones Reverendi Cancellarii et Sacri Regii Senatus Catbaloniae, ha sido identificada como la obra: "Cortiada, Miguel. 1714. Decisiones cancellarii et sacri regii senatus cathaloniae. Sumptibus Anisson, \& Pasuel. Lugduni, 2 volúmenes.

180 La obra citada con el título abreviado: Francisco Merlino Pignatello. Controversiarum forensium iuris... Regni Neapolitani ..., ha sido identificada como la obra: *Merlinus Pignatellus, Franciscus. 1668. Controversiarum forensium iuris communis: centuria prima-secunda. Sumptibus \& Typis Samuelis Chovet. Genevae, 2 volúmenes en 1 tomo.

181 La obra citada con el título abreviado: José Yáñez Parladorio. Quotidianarum differentiarum sesquicenturia, ha sido identificada como la obra: *Yáñez Parladorio, Juan. 1612. Quotidiarum differentiarum Sesquicenturia: cui ut commentarius in iustum cresceret volumen, adiectae sum eiusdem authoris quaetiones duodenigenti epistolae tres ad filios. Apud Ioannem de la Cuesta Matriti. 


\section{Tomás Carlevalio, ${ }^{182}$ Juan del Castillo Sotoma- yor, ${ }^{183}$ y Julio Caponio ${ }^{184}$-, obras de tratadistas inscritos en el mos italicus tardío -Juan García de}

182 La obra citada con el título abreviado: Tomás Carlevalio. Disputationum iuris variarum de indicis, ha sido identificada como la obra: *Carleval [o Carlevalio], Tomás. 1649. Disputationum iuris variarum ad interpretationem regiarum legum regni Castellae, et illis similium, tam ex iure neapolitano, quam ex utroque communi civili, et canonico. Apud Mariam Quignonii. Madriti, 2 tomos en 1 volumen.

183 La obra citada con el título abreviado: Juan del Castillo Sotomayor. Quotidianarum controversiarum iuris, ha sido identificada como la obra: *Castillo Sotomayor, Juan del. 1603. Quotidianarum controversiarum iuris liber primus...: in quo ususfructus singularis ettutilis tractatus continetur... Ex officina Ioannis Gratiani apud viduam: a costa de Diego Guillen... Compluti.

184 La obra citada con el título abreviado: Julio Caponio. Controversiae forenses utriusque iuris et fori, ha sido identificada como la obra: *Capone, Giulio. 1732. Controversiarum forensium utriusque iuris et foris: opus ecclesiasticis $\mathcal{E}$ saecularis indicibus ac isholis $\mathcal{E}$ foro versantibus necessarium cum decisionibus causarum in pluribus tribunalibus tum ecclesiasticis tum laicalibus factis Julii Caponii. Editio Nova denuo revisa ac emendata. Sumptibus Marci-Michaelis Bousquet. Coloniae Allobrogum. 
Complejidad y materialidad: reflexiones del Seminario del ...

$$
\text { Saavedra, }{ }^{185} \text { Sebastián Vantius, }{ }^{186} \text { José Mascardo, }{ }^{187}
$$

185 La obra citada con el título abreviado: Juan García de Saavedra. De expensis et meliorationibus, ha sido identificada como la obra: *García de Saavedra, Juan. 1578. De expensis et meliorationibus, liber unus. Apud Antonium Sanchez a Leyva: a Costa de Blas de Robles. Compluti. La obra citada con el título abreviado: Juan García de Saavedra. De hispanorum nobilitate, ha sido identificada como la obra: *García de Saavedra, Juan. 1597. Tractatus De Hispanorum nobilitate et exemptione. Ex officina Ioannis Gratiani apud viduam: a Costa de Juan de Sarria. Compluti.

186 La obra citada con el título abreviado: Sebastián Vantius. Tractatus de nullitatibus processum $\mathcal{E}$ sententiarum, ha sido identificada como la obra: *Vantius, Sebastián. 1585. Tractatus de nullitatibus processuum ac sententiarum. In Officina Q. Philippi Tingli: Apud sinphonianum Beraud et Stephanum Michalini. Lugduni.

187 La obra citada con el título abreviado: José Mascardo. Conclusionum omnium probationum, ha sido identificada como la obra: "Mascardo, José [o Giuseppe Mascardi]. 1597. Conclusiones omnium probationum, ac quaestionum, quae in utroque foro quotidie versantur... [S.n.]. Augustae Tourinoram, 2 volúmenes. 


\section{Segismundo Scaccia, ${ }^{188}$ Alfonso de Olea ${ }^{189}$ Manuel Román Valerón, ${ }^{190}$ Domingo Antúnez Portugal, ${ }^{191}$}

188 La obra citada con el título abreviado: Segismundo Scaccia. Tractatus de commercio et cambio, ha sido identificada como la obra: "Scaccia, Segismundo. 1620. Tractatus de commerciis, et cambio. Sumptibus Antonii Boëtzeri. Coloniae. La obra citada con el título abreviado: Segismundo Scaccia. Tractatus de sententia et re iudicata, ha sido identificada como la obra: "Scaccia, Segismundo. 1618. Tractatus, de iudiciis causarum civilium, criminalium, et haereticalium. Haeredum palthenianarum, ex Officina H. Palthenii. Francofurti. La obra citada con el título abreviado: Segismundo Scaccia. Tractatus de appellationibus, ha sido identificada como la obra: *Scaccia, Segismundo. 1628. Tractatus de sententia, et re iudicata. Ex officina Rovilliana: sumptibus Andreae: Iacobi \& Matthaei Prost. Lugduni. Tras consultar varios repertorios bibliográficos no ha sido posible identificar la obra citada bajo el título abreviado: Segismundo Scaccia. tractatus de indiciis.

189 La obra citada con el título abreviado: * Alfonso de Olea. Tractatus de cessione iurium et actionum, ha sido identificada como la obra: *Olea, Alfonso de. 1752. Tractatus de cessione iurium et actionum: in quo insertae sunt suo loco, additiones seu resolutiones, cum sacrae Rotae romanae decisionibus ad hancce materiam facientibus. Typographia Balleoniana. Venetiis.

190 Tras consultar varios repertorios bibliográficos no ha sido posible identificar la obra citada bajo el título abreviado: Manuel Román Valerón. De transactionibus tractatum.

191 Tras consultar varios repertorios bibliográficos no ha sido posible identificar la obra citada bajo el título abreviado: Domingo Antúnez Portugal. De donationibus iurium et bonorum Regiae Coronae. 


\author{
Lorenzo Matheu y Sanz, ${ }^{192}$ Nicolás García, ${ }^{193}$ \\ Agustín Barbosa, ${ }^{194}$ Francisco de Mostazo, ${ }^{195}$ \\ Juan de Solórzano Pereira, ${ }^{196}$ Gerónimo de
}

192 La obra citada con el título abreviado: Lorenzo Matheu y Sanz,. Tractatus de re criminali, ha sido identificada como la obra: "Matheu y Sanz, Lorenzo. 1672. Tractatus de re criminali, sive controversiarum usufrequentium in causis Criminalibus, cum earum decissionibus, tàm in Aula suprema ac Hispana Criminum, quàm in summo senatu novi orbis. Editio tertia prioribus emendatior cum triplici indice controversiarum, jurium ac rerum locupletissimo. Sumptibus Anisson. Lugduni.

193 La obra citada con el título abreviado: Nicolás García. De beneficiis tractatus, ha sido identificada como la obra: *García, Nicolás. 1613. Tractatus de beneficiis. Praelo \& expensis Ludovici Sanchez. Matriti.

194 La obra citada con el título abreviado: Agustín Barbosa. Opera, ha sido identificada como la obra: *Barbosa, Agustín. 1699. Opera Agustini Barbosae. Ed. novissima, ab authore recognita. Sumptibus Petri Borde, Joannis et Petri Arnaud. Lugduni.

$195 \mathrm{La}$ obra citada con el título abreviado: Francisco de Mostazo.

Tractatus de Causis piis, ha sido identificada como la obra: *Mostazo, Francisco. 1686. D. D. Francisci a Mostazo... De causis piis in genere, et in specie Libri VIII: opus quidem perutile non solum judicibus y Visitatoribus Ecclesiasticis, verum etiam Secularibus ... Tomus primus: diligenter recognitus, multisque mendis expurgatus ... Nunc denvo in lucem prodit. Sumptibus Petri Borde, Joannis, y Petri Arnaud. Lugduni.

196 La obra citada con el título abreviado: Juan de Solórzano Pereira. Política Indiana, ha sido identificada como la obra: *Solórzano Pereira, Juan de. 1647. Politica Indiana. $1^{a}$ Ed. Officina de Diego Diaz de la Carrera. Madrid. 
De los libros surgen las leyes. Aproximación a los fondos ...

Ustáriz, ${ }^{197}$ Francisco Salgado de Somoza, ${ }^{198}$ Gas-

197 La obra citada con el título abreviado: Gerónimo de Ustáriz. Teoría y práctica de comercio y marina, ha sido identificada como la obra: "Ustáriz, Gerónimo de. 1742. Theorica, y practica de comercio y de marina, en diferentes discursos, y calificados exemplares, que, con especificas providencias, se procuran adaptar a la monarchia española, para su prompta restauración, beneficio universal, y mayor fortaleza contra los émulos de la Real Corona; mediante la soberana protección del Rey Nuestro Señor Don Phelipe V. Por Don Geronymo de Uztariz, Cavallero del Orden de Santiago, del Consejo de su Magestad, y de la Real Junta de Comercio, y de Moneda, y Secretario de su Magestad en el Consejo, y Camara de Indias. Segunda impression, corregida y enmendada por el autor. En la Imprenta de Antonio Sanz, Impressor del Rey N. Señor, y de su Real Consejo. Madrid.

198 La obra citada con el título abreviado: Francisco Salgado de Somoza. De regia protectione, ha sido identificada como la obra: *Salgado de Somoza, Francisco. 1626. Tractatus de regia protectione vi oppressorum appellantium à causis $\mathcal{E}$ iudicibus ecclesiasticis. Sumpt. L. Prost., haeredis Roville. Lugduni, 2 volúmenes. La obra citada con el título abreviado: Francisco Salgado de Somoza. Tractatus de supplicatione ad Sanctissimum, ha sido identificada como la obra: "Salgado de Somoza, Francisco. 1664. Tractatus de supplicatione ac Sanctissimum Aliteris et de earum retentione intermin senatu. $1^{a} \mathrm{ed}$. Sumptibus Lartentii Anissan. Lyancase. La obra citada con el título abreviado: Francisco Salgado de Somoza. Labyrinthus creditorum, ha sido identificada como la obra: *Salgado de Somoza, Francisco. 1653. Labyrintbus creditorum concurrentium ad litem per debitorem communem inter illos causatam. Apud Iacobum Meursium. Antuerpiae, 2 volúmenes. 
par de Villarroel, ${ }^{199}$ Pedro Frasso, ${ }^{200}$ Antonio Joaquín de Rivadeneyra y Barrientos, ${ }^{201}$ Antonio José Álvarez de Abreu, ${ }^{202}$ Conde de la Cañada, ${ }^{203}$

199 La obra citada con el título abreviado: Gaspar de Villarroel. Gobierno eclesiástico pacífico y.., ha sido identificada como la obra: *Villarroel, Gaspar de. 1656. Gobierno Eclesiástico Pacífico y Unión de los dos Cuchillos, Pontificio y Regio. Domingo García Morás. Madrid, 2 volúmenes.

200 La obra citada con el título abreviado: *Francisco Frasso. De regio patronatu.., ha sido identificada como la obra: "Frasso, Pedro. 1677-1679. De regio patronatu: ac aliis nonnullis regaliis, regibus catholicis, in Indiarum Occidentalium Imperio, pertinentibus, quaestiones aliquae desumptae, et disputatae. In quinquaginta capita partitae. Ex Typographia Imperiali: apud Iosephum Fernandez á Buendia. Matriti, 2 tomos en 3 volúmenes.

201 La obra citada con el título abreviado: Antonio Joaquín Rivadeneyra y Barrientos. Manual compendio.., ha sido identificada como la obra: “Rivadeneyra y Barrientos, Antonio Joaquín de. 1755. Manual compendiado de el regio patronato indiano: para su mas facil uso en las materias conducentes á la práctica. Antonio Marin. Madrid, 1755.

202 La obra citada con el título abreviado: Antonio José Álvarez de Abreu,. Víctima real legal.., ha sido identificada como la obra: *Álvarez de Abreu, Antonio José. 1726. Víctima Real legal, discurso único jurídico-histórico-político sobre que las vacantes mayores y menores de las Iglesias de las Indias Occidentales, pertenecen a la corona de Castilla y León, en pleno, y absoluto dominio. En la Imprenta de Antonio Marin. Madrid.

203 Tras consultar varios repertorios bibliográficos no ha sido posible identificar la obra citada bajo el título abreviado: Conde de la Cañada. Instituciones prácticas... 
y José Covarrubias ${ }^{204}-$, obras de prácticos inscritos en el mos italicus tardío -Ignacio López de Salcedo, ${ }^{205}$ Gabriel Parexa de Quesada, ${ }^{206}$ Gonzalo Suárez de Paz, ${ }^{207}$ Juan de Hevia Bolaños, ${ }^{208}$

204 La obra citada con el título abreviado: José Covarrubias. Máximas sobre recursos de fuerza y protección, ha sido identificada como la obra: *Covarrubias, José de. 1786. Máximas sobre recursos de fuerza y protección: con el método de introducirlos en los tribunales. $2^{a}$ ed. corr. y aum. de algunas cédulas. Impr. de la Viuda de Ibarra, Hijos y Compañía. Madrid.

205 La obra citada con el título abreviado: Ignacio López de Salcedo. Singularis et excellentissima practica criminalis canonica, ha sido identificada como la obra: "López de Salcedo, Ignacio. 1594. Singularis et excellantisima practica criminalis canonica: excommunicationis, irregularitas. Apud haeredes Ioannis Gratiani. Compluti.

206 La obra citada con el título abreviado:, Gabriel Parexa de Quesada. Praxis de instrumentorum editione, ha sido identificada como la obra: *Pareja y Quesada, Gabriel. 1668. Praxis edendi, sive tractatus de universa instrumentorum editione. Editione novissima. Sumptibus Laurentii Anisson. Lugduni, 2 tomos en 1 volumen.

207 La obra citada con el título abreviado: Gonzalo Suárez de Paz. Praxis ecclesiastica et saecularis, ha sido identificada como la obra: *Suárez de Paz, Gonzalo. 1597. Praxis ecclesiasticae et secularis: cum actionum formulis $\mathcal{E}$ actis processum. Methymma I a Campo excudebat Iacobus a Canto. [Matriti], 3 tomos en 1 volumen.

208 La obra citada con el título abreviado: Juan de Hevia Bolaños. Curia Philippica, ha sido identificada como la obra: "Hevia Bolaños, Juan de. 1609. Curia philippica, donde breve y comprehendiosamente se trata de los juyzios mayormente forenses, eclesiasticos y seculares, con lo sobre ellos hasta aora dispuesta por derecho resuelto por doctores antiguos y modernos, y practicable. Por Juan Godinez de Millis. Valladolid. 
Alfonso de Villadiego Vascuñana y Montoya, ${ }^{209}$ y Gómez Bayo ${ }^{210}$, obras de la Escuela española de Derecho natural -Melchor Cano ${ }^{211}$-, obras de humanistas -Antonio Agustín, ${ }^{212}$ Francisco Ramos del Manzano, ${ }^{213}$ Francisco Ama-

209 La obra citada con el título abreviado: Alfonso de Villadiego Vascuñana y Montoya. Instrucción política y práctica judicial, ha sido identificada como la obra: "Villadiego Vascuñana y Montoya, Alfonso de. 1612. Instrucción politica y practica iudicial: conforme al estilo de los consejos, audiencias, y tribunales de corte, $y$ otros ordinarios del reyno... Luis Sanchez. Madrid.

210 La obra citada con el título abreviado: Gómez Bayo. Praxis ecclesiastica et saecularis, ha sido identificada como la obra: *Bayo, Gómez. 1640 (1639). Praxís ecclesiastica et secularis: cartineus tres libros: primum de praxi, secundum de questionibus veriis, testium de collectanea doctorum... Ex officina Mieronimi Murillo...: expensis Andreae Calderon viduae Bibliopolae. Vallisoleti.

211 No ha sido posible identificar que obra de este autor es la utilizada, puesto que no se indica: Cano, Melchor. Un volumen.

212 La obra citada con el título abreviado: Antonio Agustín. Opera, en 8 volúmenes, ha sido identificada como la obra: "Agustín, Antonio. 1765-1774. Opera omnia quae multa adbibita diligentia colligi potuenunt Antonii Augustini. Typis Josephi. Lucae, 8 volúmenes.

213 La obra citada con el título abreviado: Francisco Ramos del Manzano. Ad leges Iuliam et Papiam, ha sido identificada como la obra: *Ramos del Manzano, Francisco. 1678. Ad leges Iuliam, et Papiam et quae ex libris iuris consultorum, fragmenta ad illas inscribuntur: commentarii et reliquationes. Ex Typographia Imperiali: Apud Iosephu Fernandez de Buendia. Matriti, 3 tomos en 2 volúmenes. 
$\mathrm{ya}^{214}$ y Arnoldo Vinnio ${ }^{215}$-, obras de iusracionalistas -Johannes Heineccius ${ }^{216}$, obras de políticos del siglo XVIII -Carlos Montesquieu ${ }^{27}$-, de críticos al Derecho vigente en el siglo XVIII

214 La obra citada con el título abreviado: Francisco Amaya. In tres posteriores libri Codicis Iustiniani commentarii, ha sido identificada como la obra: *Amaya, Francisco de. 1639. In tres posteriores libros codicis Imperatoris Iustiniani commentarii cum indicibus titulorum, legum y rerum locupletissimis, quibus succedit Apologia eiusdem auctoris pro statuto Collegii Maioris Concheusis, contra calumniam D. Ioannis de Escobar. Sumptibus Iacobi y Petri Prost. Lugduni.

215 La obra citada con el título abreviado: Arnaldo Vinnio. Institutionum imperialium commentarius academicus et forensis, ha sido identificada como la obra: *Vinnius, Arnoldus. 1699. In quatuor libros Institutionum imperalium Commentarius Academicis et Forensis Arnoldi Vinnii. Editio novissima et emendatissima. Sumptibus Anisson: et Ioannis Posuel. Lugduni, 2 volúmenes.

216 La obra citada con el título abreviado: Johannes Heineccius,. Elementa iuris naturae et gentium, ha sido identificada como la obra: "Heineccius, Johann Gottlieb. 1774. Elementa juris naturae et gentium. $3^{a}$ Ed. accuratissima. Cramer \& Philibert. Genevae.

217 *Carlos Montesquieu. L'Esprit des Lois. Ha sido identificada como la obra: "Montesquieu, Carlos de Secondant Baron de la Brède et de. 1750. De L'esprit des loix: Ou du rapport que les loix doivent avoir avec la Constitution de chaque Gouvernement... Nouvelle edition / corrigée par l'auteur, E augmentee d'une table, Ed'une Carte Geograbique. Chez Barrillot \& Fils. Geneve. 
-Manuel de Lardizaval ${ }^{218}$ y Santiago Magro y Zurita y Eusebio Ventura Beleña ${ }^{219}$-, de instituciones de Derecho patrio o nacional -José Berní Catalá220-, obras de instituciones -Antonio Torres y Velasco ${ }^{221}-$, y de prácticos del siglo XVIII -José Bermúdez Febrero, ${ }^{222}$ Manuel Silvestre

218 Tras consultar varios repertorios bibliográficos no ha sido posible identificar la obra citada bajo el título abreviado: Manuel de Lardizaval. Discurso sobre las penas.

219 Tras consultar varios repertorios bibliográficos no ha sido posible identificar la obra citada bajo el título abreviado: Santiago Magro y Zurita; Ventura Beleña, Eusebio. Elucidationes ad Quatuor Libros.

220 La obra citada con el título abreviado: José Berní Catalá. Instituta civil y real, ha sido identificada como la obra: "Berni, Joseph. 1760. Instituta civil, y real en donde con la mayor brevedad se explican los de Justiniano. Benito Monfort. Valencia.

221 La obra citada con el título abreviado: Antonio Torres y Velasco. Institutiones Hispaniae practico theoricae commentatae, ha sido identificada como la obra: *Torres y Velasco, Antonio A. 1746. Institutiones hispanae. Ex Typographia Mercurii. Matriti.

222 La obra citada con el título abreviado: José Bermúdez Febrero. Librería de escribanos, ha sido identificada como la obra: *Febrero, José. 1778. Libreria de escribanos, e instruccion juridica: teorica practica de principiantes Parte primera. $2^{a}$ Ed. corregida por el autor. En la imprenta de Pedro Marin. Madrid, 3 volúmenes. 


\section{Martínez, ${ }^{223}$ José Manuel Domínguez Vicente ${ }^{224}$ y Francisco Antonio de Elizondo ${ }^{225}$. \\ 5. Doctor Francisco Pablo Matos Coronado (16?-1744) Obispo de Michoacán, poseía fuentes romanas -Corpus Iuris Civilis-, fuentes canóni- cas-Corpus Iuris Canonici, Concilio Tridentino-,}

223 La obra citada con el título abreviado: Manuel Silvestre Martínez. Librería de jueces, ha sido identificada como la obra: "Martínez, Manuel Silvestre. 1774. Librería de jueces, utilisima, y universal. Imprenta de Blas Roman. Madrid, 5 volúmenes.

224 La obra citada con el título abreviado: José Manuel Domínguez Vicente. Ilustración y continuación de la Curia Filípica, ha sido identificada como la obra: *Domínguez Vicente, José Manuel. 1736. Ilustración y continuación a la Curia Philípica, y corrección de las citas que en ella se hallan cerradas: dividido en las mismas cinco partes: trátase del modo de proceder en los juicios eclesiásticos, y seculares, con lo que sobre ello ay hasta aora dispuesto por derecho resulto por doctores antiguos, y modernos. En la Oficina de los Herederos de Juan García Infanzón. Madrid, 2 volúmenes.

225 La obra citada con el título abreviado: Diego Antonio de Elizondo. Práctica universal forense.., ha sido identificada como la obra: "Elizondo, Francisco Antonio de. 1770. Practica universal forense de los tribunales superiores de España, y de las Indias. $2^{a}$. impresión. Joachin Ibarra Impresor. Madrid. 
textos de legislación real -Siete Partidas, ${ }^{226}$ Nueva Recopilación de Castilla, Recopilación de Indias, Francisco de Montemayor ${ }^{227}$-, obras de comentaristas de fuentes romanas inscritos en el mos italicus tardío -Antonio Pichardo Vinuesa ${ }^{228}$-, obras de comentaristas de fuentes canónicas inscritos en el mos italicus tardío -Manuel González

226 La obra citada con el título abreviado Siete Partidas ha sido identificada como la obra: *Las Siete partidas del Sabio Rey don Alonso el nono, nuevamente glosadas por el Licenciado Gregorio López del Consejo Real de Indias de Su Magestad. M.D.L.V. Por Andrea de Portonaris. Salamanca.

227 La obra citada con el título abreviado: Francisco de Montemayor. Sumario de las cédulas, órdenes y provisiones reales que se han despachado por Su Majestad para la Nueva España y otras partes, ha sido identificada como la obra: ${ }^{*}$ Montemayor, Francisco de. [1678]. Summarios de las cedulas, ordenes, y provisiones reales, y otras partes; especialmente desde el año de mil seiscientos y veinte y ocho, en que se imprimieron los quatro libros, del primer tomo de la Recopilacion de Leyes de las Indias ...: que juntó y dispuso el doctor Don Iuan Francisco de Montemayior, y Cordova de Cuenca. En la Imprenta de la Viuda de Bernardo Calderón. México.

228 Tras consultar varios repertorios bibliográficos no ha sido posible identificar la obra citada bajo el título abreviado: Antonio Pichardo Vinuesa. De morae commissione et emendatione. Pichardo Vinuesa, Antonio. No ha sido posible identificar que obra de este autor es la utilizada, puesto que no se indica. 


\section{Téllez, ${ }^{229}$ Próspero Fagnanus, ${ }^{230}$ Anacleto Reif- fenstuel, ${ }^{231}$ Jerónimo González ${ }^{232}$ y Andrés Mendo $^{233}$-, obras de comentaristas de Derecho real inscritos en el mos italicus tardío -Juan de}

229 La obra citada con el título abreviado: Manuel González Téllez. Commentaria perpetua in singulos textus quinque librorum Decretalium, ha sido identificada como la obra: *González Téllez, Manuel. 1673. Commentaria perpetua in singulos textus quinque librorum Decretalium Gregorii IX. Sumptibus Laurentii Arnaud, $\&$ Petri Borde. Lugduni.

230 Tras consultar varios repertorios bibliográficos no ha sido posible identificar la obra citada bajo el título abreviado: Próspero Fagnanus. Commentaria in quinque libros Decretalium.

$231 \mathrm{La}$ obra citada con el título abreviado: Anacleto Reffenstuel. Ius Canonicum universum clara methodo iuxta titulos quinque librorum Decretalium in quaestionum distributum, ha sido identificada como la obra: "Reiffenstuel, Anacleto. 1739. Ius Canonicum universum clara methodo iuxta titulos quinque Librorum decretalium in quaestiones $2^{a}$ ed. Joannis Andreae de la Haye. Ingolstadi.

232 Tras consultar varios repertorios bibliográficos no ha sido posible identificar la obra citada bajo el título abreviado: Jerónimo González. Glossema ad Regulam VIII Cancellariae Apostolicae.

233 La obra citada con el título abreviado: Andrés Mendo. Bullae Sacrae Cruciatae dilucidationem, ha sido identificada como la obra: *Mendo, Padre Andrés. 1651. Bullae Sanctae Cruciatae elucidatio. Ex typographia Mariae de Quiñones: sumptibus Emmanuelis Lopezii. Matriti. 
Matienzo, ${ }^{234}$ Alfonso de Azevedo, ${ }^{235}$ Alfonso de Carbona, ${ }^{236}$ Francisco Carrasco del Saz ${ }^{237}$ y Gaspar de Hermosilla ${ }^{238}$-, obras de consiliaristas inscritos en el mos italicus tardío -Antonio

234 La obra citada con el título abreviado: Juan de Matienzo. In librum $V$ Collectionis Legum Hispaniae commentaria, ha sido identificada como la obra: "Matienzo, Juan de. 1597. Commentaria Ioannis Matienzo regii Senatoris in Cancellaria Argentina reggni Peru in librum quintum recollectiones legum Hispaniae. Excudebat Petrus Madrigal. Mantuae Carpentanee.

235 La obra citada con el título abreviado: Alfonso de Azevedo. Commentariorum Iuris Civilis in Hispaniae Regias Constitutiones, ha sido identificada como la obra: *Azevedo, Alfonso de. 1583-1599. Commentarium Iuris Civilis in Hispaniae Regias Constitutiones. Excudebat Cornelius Bobardus. Salmanticae, 6 volúmenes.

236 La obra citada con el título abreviado: Alfonso de Narbona. Commentaria in tertiam partem Novae Recopilationis Legum Hispaniae, ha sido identificada como la obra: *Narbona, Alfonso de. 1624. Commentaria in tertiam partem Novae Recopilationis legum Hispaniae Alphonsi Narbona. Apud Didacum Rodriguez, Typ. Regium. Toleti.

237 La obra citada con el título abreviado: Francisco Carrasco del Saz. Interpretatio ad singulas Leges Novae Recopilationes Regni Castellae, ha sido identificada como la obra: *Carrasco del Saz, Francisco. 1620. Interpretatio ad aliquas recopilationis regni castellae. Apud Hieronimum A. Contreras. Hispali.

238 La obra citada con el título abreviado: Gaspar de Hermosilla. Notae, additiones et resolutiones ad glossas Legum Partitarum, ha sido identificada como la obra: "Hermosilla, Gaspar de. 1674. Nota, additiones et resolutiones ad glossas legum partitarum D. Gregorii Lopetii. Ex officina Anissoniana. Lugduni, 2 volúmenes. 
Gómez, ${ }^{239}$ Alfonso de Azevedo, ${ }^{240}$ Juan Bautista Valenzuela Velásquez ${ }^{241}$ y Diego Ibáñez de $\mathrm{Fa}$ ría ${ }^{242}$-, obras de decisionistas inscritos en el mos italicus tardío -Juan Pedro Fontanella, ${ }^{243}$ Miguel

239 La obra citada con el título abreviado: Antonio Gómez. Variarum resolutionum ex iure regio, pontificio \& caesareo, ha sido identificada como la obra: "Gómez, Antonio. 1562-1563. Commentariorum variarúmque resolutionum iuris civilis communis $\mathcal{E}$ regii. In aedibus Andreae á Portonariis. Salmanticae, 3 tomos en 1 volumen.

240 Tras consultar varios repertorios bibliográficos no ha sido posible identificar la obra citada bajo el título abreviado: Alfonso de Azevedo. Consilia iuris responsa.

241 La obra citada con el título abreviado: Juan Bautista Valenzuela Velázquez. Consiliorum sive responsorum iuris, ha sido identificada como la obra: "Valenzuela Velázquez, Juan Bautista. 1634. Consilia sive iuris responsa. [S.n.]. Neapoli, 2 volúmenes.

242 La obra citada con el título abreviado: Ibáñez de Faría, Diego. Additiones, enucleationes et notae ad librum primum (secundum)..., ha sido identificada como la obra: "Ibáñez de Faría, Diego.1675. Additiones, observationes et nota ad libros variarum resolutionum illustrissimi ac reverendissimi D. Didaci Covarruvias A Leiva. [S.n.]. Lugduni, 1675.

243 Tras consultar varios repertorios bibliográficos no ha sido posible identificar la obra citada bajo el título abreviado: Juan Pedro Fontanella. Sacri Senatus Cataloniae decisiones. La obra citada con el título abreviado: Juan Pedro Fontanella. Sacri Senatus Cataloniae decisiones, ha sido identificada como la obra: "Fontane1la, Juan Pedro. 1639-1645. Sacri Regii Senatus Cathalonia decisiones. Ex Praelo, acaese Petri Lacavalleria. Barcinone, 2 volúmenes. 


\section{Calderó, ${ }^{244}$ Vicente de Francis ${ }^{245}$ y Cristóbal Crespi de Valldaura y Parizuela ${ }^{246}$-, obras de controversistas inscritos en el mos italicus tardío -José Yáñez Parladorio, ${ }^{247}$ Tomás Carlevalio, ${ }^{248}$}

244 La obra citada con el título abreviado: Miguel Calderó. Sacri regii criminalis Cathaloniae decisiones, ha sido identificada como la obra: *Calderó, Miguel. 1686-1701. Sacri regii criminalis concilii cathaloniae decisiones: cum additionibus ad primam, et secundam partem, et duplici indice dicisionum additionum. Ex Typographia Raphaelis Figuero. Barcinonae, 3 volúmenes.

245 La obra citada con el título abreviado: Vicente de Franchis. Corpus decisionum Sacri Regii Consilium Neapolitani, ha sido identificada como la obra: "Franchis, Vicentius de. 1594. Decisionum sacri Regii Consilii Neapolitani. Apud Iuntas. Venetiis, 2 tomos en 1 volumen.

246 La obra citada con el título abreviado: Cristóbal Crespi de Valdaura. Observationes illustratas decisionibus Sacri Supremi Aragonum Consilii S. Cruciatae \& Regiae Audientiae Valentiae, ha sido identificada como la obra: *Crespi de Valldaura y Parizuela, Cristóbal. 1662. Observationes illustrata decisionibus sacri Supremi regii aragonum consilii supremi consilii sancta cruciata $\mathcal{E}$ regia audientia Valentina. Sumptibus Horatii Boissat \& Georgii nemeus. Lugduni, 2 volúmenes.

247 Tras consultar varios repertorios bibliográficos no ha sido posible identificar la obra citada bajo el título abreviado: José Yáñez Parladorio. Quotidianarum differentiarum sesqui centuria.

248 La obra citada con el título abreviado: Tomás Carlevalio. Disputationum iuris variarum de iudiciis, ha sido identificada como la obra: *Carleval [o Carlevalio], Tomás. 1649. Disputationum iuris variarum ad interpretationem regiarum legum regni Castellae, et illis similium, tam ex iure neapolitano, quam ex utroque communi civili, et canonico. Apud Mariam Quignonii, Madriti, 2 tomos en 1 volumen. 
José Vela, ${ }^{249}$ y Julio Caponio ${ }^{250}$-, obras de alegacionistas inscritos en el mos italicus tardío -Diego Antonio Yáñez Fajardo, ${ }^{251}$ Pedro Díez de Rivadeneyra, ${ }^{252}$ Juan Bautista Larrea, ${ }^{253}$ y Antonio

249 La obra citada con el título abreviado: José Vela. Dissertationes iuris controversi in Hispalensi Senatus, ha sido identificada como la obra: *Vela de Oreña, José. 1653 (1652). Dissertationum iuris controversi tamin Hispalensi quam Granatensi senatu secundus tomus. Apud Balthasarem de Bolibar: sumptibus Bernardi Martinez y Ioannis de Moya, bibliopolarum. Granatae.

250 La obra citada con el título abreviado: Julio Caponio. Controversiae forenses utriusque iuris et fori, ha sido identificada como la obra: "Capone, Giulio. 1732. Controversiarum forensium utriusque iuris et foris: opus ecclesiasticis $\mathcal{E}$ saecularis indicibus ac i sholis $\mathcal{E}$ foro versantibus necessarium cum decisionibus causarum in pluribus tribunalibus tum ecclesiasticis tum laicalibus factis Julii Caponii. Editio Nova denuo revisa ac emendata. Sumptibus MarciMichaelis Bousquet. Coloniae Allobrogum.

251 La obra citada con el título abreviado: Diego Antonio Yáñez Fajardo. Iuris allegationum Fiscalium Mediolani in gravibus causis semicenturiam bipartitam, ha sido identificada como la obra: "Yáñez Fajardo, Diego Antonio. 1671. Iuris allegationum fiscalium mediolani in gravibus causis. Semicenturia bipartita, cui accessu Tractatus de Legimationi per subsequens matrimonium, $\mathcal{E}$ singularis quaestio regularis. Sumpt. Arnaud: et Petri Borde. Lugduni, 2 volúmenes.

252 Tras consultar varios repertorios bibliográficos no ha sido posible identificar la obra citada bajo el título abreviado: Pedro Díez de Rivadeneyra Noguerol. Allegationum iuris.

253 La obra citada con el título abreviado: Juan Bautista Larrea. Allegationes fiscales, ha sido identificada como la obra: "Larrea, Juan Bautista. 1642. Allegationum fiscalium. Sumptibus Petri Prost. Lugduni, 2 volúmenes. 


\section{de Castro $^{254}-$, obras de tratadistas inscritos en el mos italicus tardío -Domingo Espino de Cáce- res, ${ }^{255}$ Antonio Ayerve de Ayora, ${ }^{256}$ Luis de Mo- lina y Morales, ${ }^{257}$ Juan García de}

254 La obra citada con el título abreviado: Antonio de Castro. Allegationes canonicae cum suis decisionibus, ha sido identificada como la obra: *Castro, Antonio de. 1689. Allegationes Canonicae: cum suis decissionibus. Ex Officina Bernardi de Villa-Diego, Typographo regio. Matriti.

255 La obra citada con el título abreviado:, Domingo Espino de Cáceres. Speculum testamentorum, sive thesaurus universae iurisprudentiae, ha sido identificada como la obra: 'Espino de Cáceres, Diego de. 1587. Speculum testamentarum sive thesaurus universae iuris prudentia: In quo non solum causa, qua in publico foro, versantur, sed etiam qua gymnasiis a bidua at clamatione docentur, et qua in anima indicto consilii opus habent, et regali iure servantur singulari ordine illustrantur. Excudebat Ioannes Ferdinandus. Salmanticae.

256 La obra citada con el título abreviado: Antonio Ayerve de Ayora. De bonorum partitionibus tractatum, ha sido identificada como la obra: "Ayerve de Ayora, Antonio. 1622. Tractatus de partitionibus bonorum communium inter maritum, et uxorem E filios ac haeredes eorum: et fructibus dividendis tam haereditatum, quàm bonorum maioratus inter successores, $\mathcal{E}$ predecesores uxores... Apud Ioannem de Rueda typographum. Vallisoleti.

257 Tras consultar varios repertorios bibliográficos no ha sido posible identificar la obra citada bajo el título abreviado: Luis de Molina y Morales. De hispanorum primogeniis. 
Saavedra, ${ }^{258}$ Francisco Muñoz de Escobar, 259 Alfonso de Olea ${ }^{260}$ Fernando Escaño, ${ }^{261}$ Manuel

258 La obra citada con el título abreviado: Juan García de Saavedra. De expensis et meliorationibus, ha sido identificada como la obra: *García de Saavedra, Juan. 1578. De expensis et meliorationibus, liber unus. Apud Antonium Sanchez a Leyva: a Costa de Blas de Robles. Compluti. La obra citada con el título abreviado: Juan García de sSavedra,. De hispanorum nobilitate, ha sido identificada como la obra: *García de Saavedra, Juan. 1597. Tractatus De Hispanorum nobilitate et exemptione. Ex officina Ioannis Gratiani apud viduam: a Costa de Juan de Sarria. Compluti.

259 La obra citada con el título abreviado: Francisco Muñoz de Escobar. De ratiociniis administratorum $\mathcal{E}$ aliis variis computationibus, ha sido identificada como la obra: "Muñoz de Escobar, Francisco. 1682. De ratiociniis administratorum et computationibus variis aliis: tractatus praegnatissimus. Wolffgangum Mauritium et Johannis Andreae. Noribergae.

260 La obra citada con el título abreviado: Alfonso de Olea. Tractatus de cessione iurium et actionum, ha sido identificada como la obra: *Olea, Alfonso de. 1752. Tractatus de cessione iurium et actionum: in quo insertae sunt suo loco, additiones seu resolutiones, cum sacrae Rotae romanae decisionibus ad hancce materiam facientibus. Typographia Balleoniana. Venetiis.

261 La obra citada con el título abreviado: Fernando Escaño. De perfectione voluntatis testamento, ha sido identificada como la obra: "Escaño, Fernando de. 1665. Tractatus de perfectione voluntatis testamento requisita et de testamento perfecto ratione voluntatis... Apud Michaelem Aldabe... Hispali. 
Román Valerón, ${ }^{262}$ Hermenegildo de Roxas, ${ }^{263}$
Domingo Antúnez Portugal, ${ }^{264}$ Tomás Sán-
chez, ${ }^{265}$ Antonio Oliván, ${ }^{266}$ Nicolás García, ${ }^{267}$

262 Tras consultar varios repertorios bibliográficos no ha sido posible identificar la obra citada bajo el título abreviado: Román Valerón, Manuel. De transactionibus tractatum.

263 La obra citada con el título abreviado: Hermenegildo de Roxas. Tractatus posthumus de incompatibilitate regnorum ac maioratum, ha sido identificada como la obra: *Aguila y Roxas, Fernando Alfonso del. 1738. Additae quaestiones de incompatibilitate regnorum \& maioratuum, ad Tractatum d. Hermenegildi de Roxas... quem in lucem editum vidit curâ E studio d. Francisci $X i$ menes del Aguila... ubi plura utilissima et noviter discursa in materia resolvuntur, E decisionibus tribunalium Hispaniae, maximè Granatensis senatus, comprobata, ad praxim utiliter inveniuntur. Sumptibus fratrum de Tournes. Coloniae Allobrogum.

264 Tras consultar varios repertorios bibliográficos no ha sido posible identificar la obra citada bajo el título abreviado: Domingo Antúnez Portugal. De donationibus iurium et bonorum Regiae Coronae.

265 La obra citada con el título abreviado: Tomás Sánchez. De Sancto matrimonio sacramenti disputatio, probablemente se trate de: "Sánchez, Thomas. 1614. Disputationum de sancto matrimonio sacramento. Apud Haeredes Martini Nuti et Ionannem Meurisiu. Antuerpiae.

266 Tras consultar varios repertorios bibliográficos no ha sido posible identificar la obra citada bajo el título abreviado: Antonio Oliván. Tractatus de foro ecclesiae.

267 Tras consultar varios repertorios bibliográficos no ha sido posible identificar la obra citada bajo el título abreviado: Nicolás García. De beneficiis tractatus. 
Gaspar de Escalona y Agüero, ${ }^{268}$ Juan de Solórzano Pereira, ${ }^{269}$ Alfonso Pérez de Lara, ${ }^{270}$ José Veitia Linaje, ${ }^{271}$ Matías Lagúnez, ${ }^{272}$ Francisco

268 Tras consultar varios repertorios bibliográficos no ha sido posible identificar la obra citada bajo el título abreviado: Gaspar de Escalona y Agüero. Arcae Limensis.

269 La obra citada con el título abreviado: Juan de Solórzano Pereira. Política Indiana, ha sido identificada como la obra: "Solórzano Pereira, Juan de. 1647. Política Indiana. $1^{a}$ Ed. Officina de Diego Diaz de la Carrera. Madrid.

270 La obra citada con el título abreviado: Alfonso Pérez de Lara,. Compendio de las tres gracias de la bula de Cruzada, ha sido identificada como la obra: "Pérez de Lara, Alfonso. 1610. Compendio de las tres gracias de la Sancta Cruzada. Imprenta Real. Madrid.

271 La obra citada con el título abreviado: José de Veitia Linage. Norte de la contratación de las Indias ..., ha sido identificada como la obra: "Veitia Linage, José de. 1672. Norte de la contratación de las Indias Occidentales. J. F. de Blas. Sevilla.

272 La obra citada con el título abreviado: Matías Lagúnez. Tractatus de fructibus, ha sido identificada como la obra: Lagunez, Matías. 1686. Tractatus de fructibus: titulo generali in quo selectiora, qua rem fructuariam pertinens iura expendutur difficilioraque referantur. Ex Typographia Melchioris Alvarez. Matriti, 2 volúmenes. 


\begin{abstract}
Salgado de Somoza ${ }^{273}$ y Gaspar de Villarroel ${ }^{274}$-, obras de prácticos inscritos en el mos italicus tardío -Julio Claro, ${ }^{275}$ Gonzalo Suárez de Paz, ${ }^{276}$
\end{abstract}

273 La obra citada con el título abreviado: Francisco Salgado de Somoza. De regia protectione, ha sido identificada como la obra: *Salgado de Somoza, Francisco. 1626. Tractatus de regia protectione vi oppressorum appellantium à causis $\mathcal{E}$ iudicibus ecclesiasticis. Sumpt. L. Prost., haeredis Roville. Lugduni, 2 volúmenes. La obra citada con el título abreviado: Francisco Salgado de Somoza. Tractatus de supplicatione ad Sanctissimum, ha sido identificada como la obra: *Salgado de Somoza, Francisco. 1664. Tractatus de supplicatione ac Sanctissimum Aliteris et de earum retentione intermin senatu. $1^{a}$ ed. Sumptibus Lartentii Anissan. Lyancase. La obra citada con el título abreviado: Francisco Salgado de Somoza. Labyrinthus creditorum, ha sido identificada como la obra: *Salgado de Somoza, Francisco. 1653. Labyrinthus creditorum concurrentium ad litem per debitorem communem inter illos causatam. Apud Iacobum Meursium. Antuerpiae, 2 volúmenes.

274 La obra citada con el título abreviado: Gaspar de Villarroel. Gobierno eclesiástico pacífico y.., ha sido identificada como la obra: *Villarroel, Gaspar de. 1656. Gobierno Eclesiástico Pacífico y Unión de los dos Cuchillos, Pontificio y Regio. Domingo García Morás. Madrid. 2 volúmenes.

275 La obra citada con el título abreviado: Julio Claro. Practica civilis et criminalis, ha sido identificada como la obra: *Claro, Giulio. 1661. Iulii Clario pera omnia, sive practica civilis atque criminalis. Sumpt. Horatii Boissat \& Georgii Remei. Lugduni.

276 La obra citada con el título abreviado: Gonzalo Suárez de Paz,. Praxis ecclesiastica et saecularis, ha sido identificada como la obra: *Suárez de Paz, Gonzalo. 1597. Praxis ecclesiasticae et secularis: cum actionum formulis $\mathcal{E}$ actis processum. Methymma I a Campo excudebat Iacobus a Canto. [Matriti], 3 tomos en 1 volumen. 


\section{Alfonso de Villadiego Vascuñana y Monto- ya, ${ }^{277}$ Gómez Bayo ${ }^{278}$ y Jerónimo Fernández de Herrera y Villarroel ${ }^{279}$ - y obras de humanistas Francisco Ramos del Manzano, ${ }^{280}$ Francisco}

277 La obra citada con el título abreviado: Alfonso de Villadiego Vascuñana y Montoya,. Instrucción política y práctica judicial.., ha sido identificada como la obra: "Villadiego Vascuñana y Montoya, Alfonso de. 1612. Instrucción politica y practica iudicial: conforme al estilo de los consejos, audiencias, y tribunales de corte, y otros ordinarios del reyno ... Luis Sanchez. Madrid.

278 La obra citada con el título abreviado: Gómez Bayo. Praxis ecclesiastica et saecularis, ha sido identificada como la obra: "Bayo, Gómez. 1640 (1639). Praxís ecclesiastica et secularis: cartineus tres libros: primum de praxi, secundum de questionibus veriis, testium de collectanea doctorum... Ex officina Mieronimi Murillo...: expensis Andreae Calderon viduae Bibliopolae. Vallisoleti.

279 La obra citada con el título abreviado: Jerónimo Fernández de Herrera y Villarroel. Práctica criminal, ha sido identificada como la obra: *Fernández de Herrera Villarroel, Jerónimo. 1672. Practica Criminal instrucción ... de substanciar las causas, con distinción de lo que... se debe observar, assi en los Consejos, y Sala, como en otros Tribunales superiores, y en los inferiores de juezes, pesquisidores, y ordinarios, por los escrivanos à quienes suelen cometerse, en que se notan muchas de las difucultades que se ofrecen en el todo, y en parte de ellas ... En la Imprenta Real. Madrid.

280 La obra citada con el título abreviado: Francisco Ramos del Manzano. Ad leges Iuliam et Papiam, ha sido identificada como la obra: "Ramos del Manzano, Francisco. 1678. Ad leges Iuliam, et Papiam et quae ex libris iuris consultorum, fragmenta ad illas inscribuntur: commentarii et reliquationes. Ex Typographia Imperiali: Apud Iosephu Fernandez de Buendia. Matriti, 3 tomos en 2 volúmenes. 


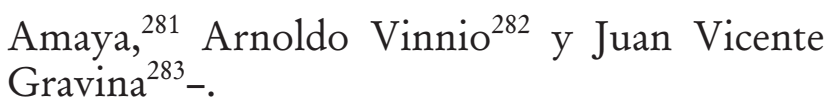

6. José Manuel Messia de la Cerda y Vargas (1695-1760) Alcalde del Crimen de la Real Audiencia de México, poseía fuentes canónicas -Corpus Iuris Canonici-, textos de legislación

281 Tras consultar varios repertorios bibliográficos no ha sido posible identificar la obra citada bajo el título abreviado: Francisco Amaya. Observationum iuris libri tres. La obra citada con el título abreviado: Amaya, Francisco. In tres posteriores libros Codicis Iustiniani commentarii, ha sido identificada como la obra: *Amaya, Francisco de. 1639. In tres posteriores libros codicis Imperatoris Iustiniani commentarii cum indicibus titulorum, legum y rerum locupletissimis, quibus succedit Apologia eiusdem auctoris pro statuto Collegii Maioris Concheusis, contra calumniam D. Ioannis de Escobar. Sumptibus Iacobi y Petri Prost. Lugduni.

282 La obra citada con el título abreviado: Arnaldo Vinnio. Institutionum imperialium commentarius academicus et forensis, ha sido identificada como la obra: *Vinnius, Arnoldus. 1699. In quatuor libros Institutionum imperalium Commentarius Academicis et Forensis Arnoldi Vinnii. Editio novissima et emendatissima. Sumptibus Anisson: et Ioannis Posuel. Lugduni, 2 volúmenes.

283 La obra citada con el título abreviado: Juan Vicente Gravina. Originum iuris civilis libri tres, ha sido identificada como la obra: *Gravina, Gianvicenzo. 1737. Opera seu originum iuris civilis: libri tres quibus accedunt de romano imperio liber singularis eiusque orationes et opuscula latina Jani Vicentii Gravinae. Recensuit et adnotationibus auxit Gottfridus Mascovius. Apud Joh. Frid. Gledistehii B. Filium. Lipsiae. 
real-Francisco de Montemayor ${ }^{284}$-, obras de comentaristas -Paulo de Castro ${ }^{285}$-, obras de comentaristas de fuentes romanas inscritos en el mos italicus tardío -Pedro Barbosa ${ }^{286}$-, obras de comentaristas de fuentes canónicas inscritos en el mos italicus tardío -Jerónimo González ${ }^{287}$

284 La obra citada con el título abreviado: Francisco de Montemayor. Sumario de las cédulas, órdenes y provisiones reales que se han despachado por Su Majestad para la Nueva España y otras partes, ha sido identificada como la obra: *Montemayor, Francisco de. [1678]. Summarios de las cedulas, ordenes, y provisiones reales, y otras partes; especialmente desde el año de mil seiscientos y veinte y ocho, en que se imprimieron los quatro libros, del primer tomo de la Recopilacion de Leyes de las Indias ...: que juntó y dispuso el doctor Don Iuan Francisco de Montemayior, y Cordova de Cuenca. En la Imprenta de la Viuda de Bernardo Calderón. México.

285 Tras consultar varios repertorios bibliográficos no ha sido posible identificar la obra citada bajo el título abreviado: Castro, Paulo de. Opera, en siete volúmenes.

286 Tras consultar varios repertorios bibliográficos no ha sido posible identificar la obra citada bajo el título abreviado: Pedro Barbosa. Commentaria ad rubricam et legem Codicis de Praescriptionibus, Commentaria ad interpretationem tituli Pandectarum de indiciis. Tras consultar varios repertorios bibliográficos no ha sido posible identificar la obra citada bajo el título abreviado: Pedro Barbosa. Commentaria ad interpretationem tit. De soluto matrimonio.

287 Tras consultar varios repertorios bibliográficos no ha sido posible identificar la obra citada bajo el título abreviado: González, Jerónimo. Glossema ad Regulam VIII Cancellariae Apostolicae. 


\begin{abstract}
obras de comentaristas de Derecho real inscritos en el mos italicus tardío Cristóbal de Paz, ${ }^{288}$ Diego Pérez de Salamanca, ${ }^{289}$ Marcos Salón de Paz, Juan Guillén de Cervantes, ${ }^{291}$ Juan de Matienzo, ${ }^{292}$
\end{abstract}

288 La obra citada con el título abreviado: Cristóbal de Paz. Scholia ad Leges Regias Styli, ha sido identificada como la obra: "Paz, Christophoro de. 1608. Scholia ad leges regias styli. Apud Alphonsum Martinum Typographum. Madriti.

289 La obra citada con el título abreviado: Diego Pérez de Salamanca. Commentaria in librum VIII Ordinationum Regni Castellae, ha sido identificada como la obra: *Pérez de Salamanca, Didaco. 1574. Commentaria in quatuor posteriores libros ordinationum regni Castellae. S. C. M. Typographi. Salamanca.

290 La obra citada con el título abreviado: Marcos de Salón de Paz,. Ad leges Taurinas insignes commentarii, ha sido identificada como la obra: "Salón de Paz, Marcos. 1568. Ad Leges Taurinas insignes comentarii: nunc primum in lucem soliti: quorum bic codex primus est tomus, in quo qyatuo insunt exactissimale relectiones. Apud Franciscum Ferdinan á Corduba, regal. typogra. Pinciae.

291 Tras consultar varios repertorios bibliográficos no ha sido posible identificar la obra citada bajo el título abreviado: Juan Guillén de Cervantes. Prima pars commentariorum in leges Tauri.

292 La obra citada con el título abreviado: Juan de Matienzo. In librum $V$ Collectionis Legum Hispaniae commentaria, ha sido identificada como la obra: "Matienzo, Juan de. 1597. Commentaria Ioannis Matienzo regii Senatoris in Cancellaria Argentina reggni Peru in librum quintum recollectiones legum Hispaniae. Excudebat Petrus Madrigal. Mantuae Carpentanee. 


\begin{abstract}
Alfonso de Carbona, ${ }^{293}$ Francisco Carrasco del Saz, ${ }^{294}$ Gaspar de Hermosilla ${ }^{295}$ y Santiago Magro y Zurita ${ }^{296}$-, obras de consiliaristas inscritos en el mos italicus tardío -Antonio Gómez, ${ }^{297}$
\end{abstract}

293 La obra citada con el título abreviado: Alfonso de Narbona. Commentaria in tertiam partem Novae Recopilationis Legum Hispaniae, ha sido identificada como la obra: *Narbona, Alfonso de. 1624. Commentaria in tertiam partem Novae Recopilationis legum Hispaniae Alphonsi Narbona. Apud Didacum Rodriguez, Typ. Regium. Toleti.

294 La obra citada con el título abreviado: Francisco Carrasco del Saz. Interpretatio ad singulas Leges Novae Recopilationes Regni Castellae, ha sido identificada como la obra: *Carrasco del Saz, Francisco. 1620. Interpretatio ad aliquas recopilationis regni castellae. Apud Hieronimum A. Contreras. Hispali.

295 Tras consultar varios repertorios bibliográficos no ha sido posible identificar la obra citada bajo el título abreviado: Gaspar de Hermosilla. Notae, additiones et resolutiones ad glossas Legum Partitarum D. Gregorii Lopetii.

296 Tras consultar varios repertorios bibliográficos no ha sido posible identificar la obra citada bajo el título abreviado: Santiago Magro y Zurita. Indice de las proposiciones de las leyes de la Recopilación.

297 La obra citada con el título abreviado: Antonio Gómez. Variarum resolutionum ex iure regio, pontificio E caesareo, ha sido identificada como la obra: *Gómez, Antonio. 1562-1563. Commentariorum variarúmque resolutionum iuris civilis communis $\mathcal{E}$ regii. In aedibus Andreae á Portonariis. Salmanticae, 3 tomos en 1 volumen. 
Própero Farinacio, ${ }^{298}$ Juan Bautista Valenzuela Velázquez ${ }^{299}$-, obras de decisionistas inscritos en el mos italicus tardío -Própero Farinacio, ${ }^{300}$ Juan Pedro Fontanella, ${ }^{301}$ Juan Bautista Larrea, ${ }^{302}$

298 La obra citada con el título abreviado: Próspero Farinacio. Consilia sive responsa atque decisionum causarum criminalium, ha sido identificada como la obra: "Farinacio [o Farinacci], Próspero. 1649. Consilia sive Responsa atque decisiones causarum criminalium. Excudebat Phillipus Gamonetus. Colonia Allobrogum.

299 La obra citada con el título abreviado: Juan Bautista Valenzuela Velázquez. Consiliorum sive responsorum iuris, ha sido identificada como la obra: *Valenzuela Velázquez, Juan Bautista. 1634. Consilia sive iuris responsa. [S.n.]. Neapoli, 2 volúmenes.

300 Tras consultar varios repertorios bibliográficos no ha sido posible identificar la obra citada bajo el título abreviado: Próspero Farinacio. Decisiones Rotae. 1623.

301 La obra citada con el título abreviado: Juan Pedro Fontanella. Sacri Senatus Cataloniae decisiones, ha sido identificada como la obra: "Fontanella, Juan Pedro. 1639-1645. Sacri Regii Senatus Cathalonia decisiones. Ex Praelo, acaese Petri Lacavalleria. Barcinone, 2 volúmenes.

302 La obra citada con el título abreviado: Juan Bautista Larrea. Novae Decisiones Granatensis, ha sido identificada como la obra: "Larrea, Juan Bautista. 1647-1648. Novarum decisionum sacri regii Senatus granatensis, regni Castellae. Haered. Petri Prost, Phillippi Borde, \& Laurentii Arnaud. Turnoni, 2 volúmenes. 


\section{Miguel Calderó, ${ }^{303}$ Vicente de Francis, ${ }^{304}$ Mario Giurba, ${ }^{305}$ Luis Postio, ${ }^{306}$ Juan Bautista de $\mathrm{Luca}^{307}$ y Miguel Cortiada ${ }^{308}$, obras de contro-}

303 Tras consultar varios repertorios bibliográficos no ha sido posible identificar la obra citada bajo el título abreviado: Miguel Calderó. Sacri regii criminalis Cathaloniae decisiones.

304 La obra citada con el título abreviado: Vicente de Franchis. Corpus decisionum Sacri Regii Consilium Neapolitani, ha sido identificada como la obra: "Franchis, Vicentius de. 1594. Decisionum sacri Regii Consilii Neapolitani. Apud Iuntas. Venetiis, 2 tomos en 1 volumen.

305 La obra citada con el título abreviado: Mario Giurba. Observationes et decisiones Tribunalium Siciliae, ha sido identificada como la obra: "Giurba, Mario. 1652. Tribunalium sicilia decisa observationes. Ex typographeo Ioannis Blaeu. Amsteladami.

306 La obra citada con el título abreviado: Luis Postio. Decisiones Sacrae Rotae Bononiensis, ha sido identificada como la obra: *Postio, Luis. 1674. Sacrotae romanas decisiones ad tractarum mandati de manu tenendo. Ex Typographia' Marthael i Liberal, et Simonis Potin. Lyon.

307 La obra citada con el título abreviado: Juan Bautista de Luca. Sacrae Rotae Romanae Decisiones, ha sido identificada como la obra: "Luca, Cardenal Juan Baustista de. 1759. Sacrae rotae romanae Decisiones, et sumomorum pontificum constitutiones recentissimae, Theatrum verita et justitae. Ex typographia Balleoniana. Venetiis.

308 La obra citada con el título abreviado: Miguel Cortiada. Decisiones Reverendi Cancellarii et Sacri Regii Senatus Cathaloniae, ha sido identificada como la obra: *Cortiada, Miguel. 1714. Decisiones cancellarii et sacri regii senatus cathaloniae. Sumptibus Anisson, \& Pasuel. Lugduni, 2 volúmenes. 
versistas inscritos en el mos italicus tardío -Fernando Vásquez de Menchaca ${ }^{309}$ y Tomás Carlevalio $^{310}$, obras de alegacionistas inscritos en el mos italicus tardío -Diego Antonio Yáñez Fajardo, ${ }^{311}$ Pedro Diez de Rivadeneyra Noguerol ${ }^{312}$ y

309 La obra citada con el título abreviado: Fernando Vázquez de Menchaca,. Controversiarum illustrium, ha sido identificada como la obra: *Vázquez de Menchaca, Fernando. 1563. Controversiarum usu frequentium libri tres. In aedibus Claudii Bornat. Barcinone.

310 La obra citada con el título abreviado: Tomás Carlevalio. Disputationum iuris variarum de iudiciis, ha sido identificada como la obra: *Carleval [o Carlevalio], Tomás. 1649. Disputationum iuris variarum ad interpretationem regiarum legum regni Castellae, et illis similium, tam ex iure neapolitano, quam ex utroque communi civili, et canonico. Apud Mariam Quignonii. Madriti, 2 tomos en 1 volumen.

311 Tras consultar varios repertorios bibliográficos no ha sido posible identificar la obra citada bajo el título abreviado: Diego Antonio Yáñez Fajardo,. Iuris allegationum Fiscalium Mediolani in gravibus causis semicenturiam bipartitam.

312 La obra citada con el título abreviado: Pedro Diez de Rivadeneyra Noguerol. Allegationum iuris, ha sido identificada como la obra: "Diez de Rivadeneyra Nogueral, Pedro. 1656. Allegationum iuris: in quibus quam plures quaestiones summe necessariae in supremae Hispaniarum Curiae tribunalibus disceptatae ad praxim us umque forensem spectantes enuncleantur: opus novum...; cum duplici indice... Ex Typographia Regia: a Costa de Manuel Lopez mercader de libros. Matriti. 
Juan Bautista Larrea ${ }^{313}$-, obras de tratadistas inscritos en el mos italicus tardío -Cristóbal de $\mathrm{Paz},{ }^{314}$ Antonio Ayerve de Ayora, ${ }^{315}$ Antonio Peregrino, ${ }^{316}$ Alfonso Guzmán Genzor, ${ }^{317}$ Juan

313 La obra citada con el título abreviado: Juan Bautista Larrea. Allegationes fiscales, ha sido identificada como la obra: "Larrea, Juan Bautista. Allegationum fiscalium. 1642. Sumptibus Petri Prost. Lugduni, 2 volúmenes.

314 Tras consultar varios repertorios bibliográficos no ha sido posible identificar la obra citada bajo el título abreviado: Cristobal de Paz. De maioratibus, et eorum tenuta, seu interrdicto et remedio possessorio.

315 La obra citada con el título abreviado: Antonio Ayerve de Ayora. De bonorum partitionibus tractatum, ha sido identificada como la obra: *Ayerve de Ayora, Antonio. 1623. Tractatus de partitionibus bonorum communium inter maritum, et uxorem $\mathcal{E}$ filios ac haeredes eorum: et fructibus dividendis tam baereditatum, quàm bonorum maioratus inter successores, E pradecesores uxores... Apud Ioannem de Rueda typographum. Vallisoleti.

316 La obra citada con el título abreviado: Antonio Peregrino. De iuribus et privilegiis fisci, ha sido identificada como la obra: "Peregrino, Marco Antonio. 1587. De iuribus et privilegiis fisci... Apud Paulum Meietum Bibliopolam Pataninum. Venetiis.

317 La obra citada con el título abreviado: Alfonso Guzmán Genzor. Tractatus de evictionibus, ha sido identificada como la obra: *Guzmán Genzor, Alfonso. 1629. Tractatus de evictionibus. Omnibus quidem iuri operam damtibus, tam in theorica, quàm in praxiperutilis, et non munùs iudicibus, quàm advocatis valdè neccesarius. In quo ... Apud viduam Ildephonsi Martin. Matriti. 


\author{
Juan García de Saavedra, ${ }^{318}$ Nuño de Acosta, ${ }^{319}$ \\ Sebastián Vantius, ${ }^{320}$ José Mascardo, ${ }^{321}$ Francisco
}

318 La obra citada con el título abreviado: Juan García de Saavedra,. De expensis et meliorationibus, ha sido identificada como la obra: *García de Saavedra, Juan. 1578. De expensis et meliorationibus, liber unus. Apud Antonium Sanchez a Leyva: a Costa de Blas de Robles. Compluti. La obra citada con el título abreviado: Juan García de Saavedra. De bispanorum nobilitate, ha sido identificada como la obra: *García de Saavedra, Juan. 1597. Tractatus De Hispanorum nobilitate et exemptione. Ex officina Ioannis Gratiani apud viduam: a Costa de Juan de Sarria. Compluti.

319 La obra citada con el título abreviado: Nuño de Acosta. De privilegiis creditorum tractatus absolutissimum, ha sido identificada como la obra: *Acosta, Nuño de. 1739. De privilegiis creditorum: tractatus absolutissimus in quo celebriores, $\mathcal{E}$ in uso forensi frequentiores quaestiones de praederentis creditorum discutiuntur, E salidissima doctrina resolvuntur. Sumptibus Haeredum Cramer et fratum Philibert. Genevae.

320 La obra citada con el título abreviado: Sebastián Vantius. Tractatus de nullitatibus processum $\mathcal{E}$ sententiarum, ha sido identificada como la obra: *Vantius, Sebastián. 1585. Tractatus de nullitatibus processuum ac sententiarum. In Officina Q. Philippi Tingli: Apud sinphonianum Beraud et Stephanum Michalini. Lugduni.

321 La obra citada con el título abreviado: José Mascardo. Conclusionum omnium probationum, ha sido identificada como la obra: *Mascardo, José [o Giuseppe Mascardi]. 1597. Conclusiones omnium probationum, ac quaestionum, quae in utroque foro quotidie versantur ... [S.n.]. Augustae Tourinoram, 2 volúmenes. 
Carpio, ${ }^{322}$ Feliciano de Solís, ${ }^{323}$ Francisco Muñoz de Escobar, ${ }^{324}$ Diego Bolero y Caxal, ${ }^{325}$ Alfonso de Olea, ${ }^{326}$ Manuel Román

322 La obra citada con el título abreviado: Francisco Carpio. De executoribus et commissariis testamentariis libri quatuor, ha sido identificada como la obra: *Carpio, Francisco del. 1638. De executoribus et commissariis testamentariis. Excudebat Ludovicus estipihan. Ursaone.

323 La obra citada con el título abreviado: Feliciano de Solís. De censibus quatuor libris, ha sido identificada como la obra: "Solís, Feliciano de. 1594. Commentarii de censibus, quatuor libris fere omnem materiam de censibus complectentes. Ex officina Joannis Gratiani defuncti: impensis Ioannis Sarriae. Compluti.

324 La obra citada con el título abreviado: Francisco Muñoz de Escobar. De ratiociniis administratorum $\mathcal{E}$ aliis variis computationibus, ha sido identificada como la obra: "Muñoz de Escobar, Francisco. 1682. De ratiociniis administratorum et computationibus variis aliis: tractatus praegnatissimus. Wolffgangum Mauritium et Johannis Andreae. Noribergae.

325 La obra citada con el título abreviado: Diego Bolero y Caxal,. De decoctione debitorum fiscalium, ha sido identificada como la obra: *Bolero Cajal, Diego. 1675. De decoctione debitorum fiscalium, et eorum bonis curandis, et distrabendis, ut fisco, et creditoribus satisfiat, et de iurisalictione tribunalis decoctionum buius cuariae. Ex officina Lucae Antonii de Bealmar typographi. Matriti.

326 La obra citada con el título abreviado: Alfonso de Olea,. Tractatus de cessione iurium et actionum, ha sido identificada como la obra: *Olea, Alfonso de. 1752. Tractatus de cessione iurium et actionum: in quo insertae sunt suo loco, additiones seu resolutiones, cum sacrae Rotae romanae decisionibus ad hancce materiam facientibus. Typographia Balleoniana. Venetiis. 


\section{Valerón, ${ }^{327}$ Luis Postio, ${ }^{328}$ Domingo Antúnez Portugal, ${ }^{329}$ Blas Ultimar, ${ }^{330}$ Melchor Meres, ${ }^{331}$}

327 Tras consultar varios repertorios bibliográficos no ha sido posible identificar la obra citada bajo el título abreviado: Manuel Román Valerón. De transactionibus tractatum.

328 La obra citada con el título abreviado: Luis Postio. Tractatus de subhastatione, ha sido identificada como la obra: "Postio, Luis. 1652. De subhastatione: tractatus non superfluus, sed necessarius, $\mathcal{E}$ ad praxim aptatus, E ordinatus. Sumptibus Iohannis de Tournes. Genevae. La obra citada con el título abreviado: Luis Postio. Tractatus mandati de manutendo, ha sido identificada como la obra: *Postio, Luis. 1674. Sacrotae romanas decisiones ad tractarum mandati de manu tenendo. Ex Typographia' Marthael i Liberal, et Simonis Potin. Lyon.

329 Tras consultar varios repertorios bibliográficos no ha sido posible identificar la obra citada bajo el título abreviado: Domingo Antúnez Portugal,. De donationibus iurium et bonorum Regiae Coronae.

330 La obra citada con el título abreviado: Blas Altimar. Tractatus de nullitatibus sententiarum, ha sido identificada como la obra: *Altimari, Blas. 1704. Tractatus de nullitatibus contractuum, quasi contractuum, distractuum, utimarum voluntatum $\mathcal{E}$ quorumcumque, actuum extraiudicilium D. Blasii Altimari. Apud Paulum Balleonium. Venetiis.

331 Tras consultar varios repertorios bibliográficos no ha sido posible identificar la obra citada bajo el título abreviado: Melchor Meres. De maioratus et meliorationibus Hispaniae. 


\section{Nicolás García, ${ }^{332}$ Agustín Barbosa, ${ }^{333}$ Francisco de Mostazo, ${ }^{334}$ Francisco Alfaro, ${ }^{335}$ Gabriel Álvarez de Velasco, ${ }^{336}$ Alfonso Pérez de Lara, ${ }^{337}$}

332 Tras consultar varios repertorios bibliográficos no ha sido posible identificar la obra citada bajo el título abreviado: Nicolás García. De beneficcis tractatus.

333 La obra citada con el título abreviado: Agustín Barbosa. Opera, ha sido identificada como la obra: "Barbosa, Agustín. 1699. Opera Agustini Barbosae. Ed. novissima, ab authore recognita. Sumptibus Petri Borde, Joannis et Petri Arnaud. Lugduni.

334 La obra citada con el título abreviado: Francisco de Mostazo. Tractatus de Causis piis, ha sido identificada como la obra: "Mostazo, Francisco. 1686. D. D. Francisci a Mostazo... De causis piis in genere, et in specie Libri VIII: opus quidem perutile non solum judicibus y Visitatoribus Ecclesiasticis, verum etiam Secularibus ... Tomus primus: diligenter recognitus, multisque mendis expurgatus ... Nunc denvo in lucem prodit. Sumptibus Petri Borde, Joannis, y Petri Arnaud. Lugduni.

335 La obra citada con el título abreviado: Francisco Alfaro. Tractatus de officio fiscalis deque fiscalibus privilegiis, ha sido identificada como la obra: "Alfaro, Francisco de. 1606. Tractatus de officio fiscalis, deque fiscalibus privilegiis. Apud Ludovicum Sanchez. Vallisoleti.

336 La obra citada con el título abreviado: Gabriel Álvarez de Velasco,. Tractatus de privilegiis panperorum et miserabilis personae, ha sido identificada como la obra: "Álvarez de Velasco, Gabriel. 1630. Tractatus de privilegiis panperum et miserabilium personarum: pars prima-secunda... Apud viduam Ildephonsi Martin: expensis Dominici Gonçalez. Matriti.

337 La obra citada con el título abreviado: Alfonso Pérez de Lara,. Compendio de las tres gracias de la bula de Cruzada, ha sido identificada como la obra: *Pérez de Lara, Alfonso. 1610. Compendio de las tres gracias de la Sancta Cruzada. Imprenta Real. Madrid. 
José Veitia Linaje, ${ }^{338}$ Matías Lagúnez, ${ }^{339}$ Gaspar de Villarroel, ${ }^{340}$ Pedro Frasso ${ }^{341}$ y Antonio José Álvarez de $\mathrm{Abreu}^{342}$-, obras de prácticos inscritos

338 La obra citada con el título abreviado: José de Veitia Linage. Norte de la contratación de las Indias ..., ha sido identificada como la obra: *Veitia Linage, José de. 1672. Norte de la contratación de las Indias Occidentales. J. F. de Blas. Sevilla.

339 La obra citada con el título abreviado: Matías Lagúnez. Tractatus de fructibus, ha sido identificada como la obra: 'Lagunez, Matías. 1686. Tractatus de fructibus: titulo generali in quo selectiora, qua rem fructuariam pertinens iura expendutur difficilioraque referantur. Ex Typographia Melchioris Alvarez. Matriti, 2 volúmenes.

340 La obra citada con el título abreviado: Gaspar de Villarroel. Gobierno eclesiástico pacífico y..., ha sido identificada como la obra: *Villarroel, Gaspar de. 1656. Gobierno Eclesiástico Pacífico y Unión de los dos Cuchillos, Pontificio y Regio. Domingo García Morás. Madrid, 2 volúmenes.

341 La obra citada con el título abreviado: Pedro Frasso. De regio patronatu.., ha sido identificada como la obra: "Frasso, Pedro. 1677-1679. De regio patronatu: ac aliis nonnullis regaliis, regibus catholicis, in Indiarum Occidentalium Imperio, pertinentibus, quaestiones aliquae desumptae, et disputatae. In quinquaginta capita partitae. Ex Typographia Imperiali: apud Iosephum Fernandez á Buendia. Matriti, 2 tomos en 3 volúmenes.

342 La obra citada con el título abreviado: Antonio José Álvarez de Abreu. Víctima real legal.., ha sido identificada como la obra: *Álvarez de Abreu, Antonio José. 1726. Víctima Real legal, discurso único jurídico-histórico-político sobre que las vacantes mayores y menores de las Iglesias de las Indias Occidentales, pertenecen a la corona de Castilla y León, en pleno, y absoluto dominio. En la Imprenta de Antonio Marin. Madrid. 
en el mos italicus tardío -Ignacio López de Salcedo, ${ }^{343}$ Gabriel Parexa de Quesada, ${ }^{344}$ Alfonso de Villadiego Vascuñana y Montoya, ${ }^{345}$ Gómez Bayo $^{346}$ y Jerónimo Fernández de Herrera y

343 La obra citada con el título abreviado: Ignacio López de Salcedo. Singularis et excellentissima practica criminalis canonica, ha sido identificada como la obra: *López de Salcedo, Ignacio. 1594. Singularis et excellantisima practica criminalis canonica: excommunicationis, irregularitas... Apud haeredes Ioannis Gratiani. Compluti, 1594.

344 La obra citada con el título abreviado: Gabriel Parexa de Quesada. Praxis de instrumentorum editione, ha sido identificada como la obra: *Pareja y Quesada, Gabriel. 1668. Praxis edendi, sive tractatus de universa instrumentorum editione. Editione novissima. sumptibus Laurentii Anisson. Lugduni, 2 tomos en 1 volumen.

345 La obra citada con el título abreviado: Alfonso de Villadiego Vascuñana y Montoya. Instrucción política y práctica judicial, ha sido identificada como la obra: *Villadiego Vascuñana y Montoya, Alfonso de. 1612. Instrucción politica y practica iudicial: conforme al estilo de los consejos, audiencias, y tribunales de corte, y otros ordinarios del reyno... Luis Sanchez. Madrid.

346 La obra citada con el título abreviado: Gómez Bayo. Praxis ecclesiastica et saecularis, ha sido identificada como la obra: "Bayo, Gómez. 1640 (1639). Praxís ecclesiastica et secularis: cartineus tres libros: primum de praxi, secundum de questionibus veriis, testium de collectanea doctorum... Ex officina Mieronimi Murillo...: expensis Andreae Calderon viduae Bibliopolae. Vallisoleti. 


\section{Villarroel ${ }^{347}$ - y obras de la Escuela española de Derecho natural -Luis de Molina, ${ }^{348}$ Francisco Suárez, ${ }^{349}$ y Leonardo Lessius ${ }^{350}$-, obras de hu- manistas -Andrés Alciato, ${ }^{351}$ Francisco Ramos}

347 La obra citada con el título abreviado: Jerónimo Fernández de Herrera y Villarroel. Práctica criminal, ha sido identificada como la obra: *Fernández de Herrera Villarroel, Jerónimo. 1672. Practica Criminal instrucción... de substanciar las causas, con distinción de lo que... se debe observar, assi en los Consejos, y Sala, como en otros Tribunales superiores, y en los inferiores de juezes, pesquisidores, y ordinarios, por los escrivanos à quienes suelen cometerse, en que se notan muchas de las difucultades que se of recen en el todo, y en parte de ellas... En la Imprenta Real. Madrid.

348 La obra citada con el título abreviado: Luis de Molina. De iustitia et iure, ha sido identificada como la obra: *Molina, Luis de. 1614. De Iustitia et iure. R. P. Lodovici Molina. Excudebat Balthasar Lippius. Moguntia.

349 La obra citada con el título abreviado: Francisco Suárez. De legibus, ha sido identificada como la obra: *Suárez, Francisco. 1613. Tractatus de legibus ac deo legislatore, in decem libus distributus. Apud Joannem Kurbergium. Antuerpia.

350 La obra citada con el título abreviado: Leonardo Lessius. De iustitia et iure actionum moralium libri quatuor, ha sido identificada como la obra: "Lessius, Leonardo (S.I.). 1622. De iustitia et iure ceterique virtutibus Cardinalibus. Libri quatuor Accesi... consultatio de vera fide et religione capessenda. Sumptibus Ludovici Prost. Haeredes Roville. Lugduni.

351 La obra citada con el título abreviado: Andrés Alciato. Opera, ha sido identificada como la obra: *Alciati, Andreae. 1616-1617. Opera omnia in quator tomos... digesta... indice locuplentissimo adancta. Sumptibus haeredum Lazari Zetzeneri. Francofurti, 5 tomos en 3 volúmenes. 
De los libros surgen las leyes. Aproximación a los fondos ...

del Manzano ${ }^{352}$ y Francisco Amaya ${ }^{353}-$.

7. Pedro Anselmo Sánchez de Tagle (17?-1777) Obispo de Durango, poseía fuentes romanas -Corpus Iuris Civilis, Digesto, e Instituciones de Justiniano-, fuentes canónicas -Corpus Iuris Canonici, Concilio Tridentino, y Tercer Concilio Mexicano-, textos de legislación real -Siete Partidas, ${ }^{354}$ Ordenanzas Reales de Castilla, Nueva Recopilación de Castilla, Recopilación de Indias-,

352 La obra citada con el título abreviado: Francisco Ramos del Manzano. Ad leges Iuliam et Papiam, ha sido identificada como la obra: "Ramos del Manzano, Francisco. 1678. Ad leges Iuliam, et Papiam et quae ex libris iuris consultorum, fragmenta ad illas inscribuntur: commentarii et reliquationes. Ex Typographia Imperiali: Apud Iosephu Fernandez de Buendia. Matriti, 3 tomos en 2 volúmenes.

353 La obra citada con el título abreviado: Francisco Amaya. Observationum iuris libri tres, ha sido identificada como la obra: *Amaya, Francisco de. 1625. Observationum Iuris: libri tres. Excudebat Antonia Ramirez. Salmanticae.

354 La obra citada con el título abreviado Siete Partidas ha sido identificada como la obra: "Las Siete partidas del Sabio Rey don Alonso el nono, nuevamente glosadas por el Licenciado Gregorio López del Consejo Real de Indias de Su Magestad. M.D.L.V. Por Andrea de Portonaris. Salamanca. 
obras de comentaristas -Oldrado de Ponte ${ }^{355}$ y Martín de Azpilcueta ${ }^{356}$-, obras de comentaristas de fuentes romanas inscritos en el mos italicus tardío -Antonio Pérez ${ }^{357}$-, obras de comentaristas de fuentes romanas inscritos en el mos italicus tardío -Manuel González Téllez, ${ }^{358}$ Próspero

355 La obra citada con el título abreviado: Oldrado de Ponte. Consilia, ha sido identificada como la obra: "Ponte de Laude, Oldradus. 1550. Consilia. [S.n.]. Lugduni.

356 Martín de Azpilcueta. 1594. Conciliorum et responsorum Martinmi Azpilereta: quae in quinque libros, iuxta numerum el titulos Decretalium, distribuntur; accesitivitio iudex títulorum totius Iuris Canonici, et numeros consiliorum...; generalia totius iuxis axiomata, et sententias, quas maxime intriusque fori iudicum seire intrest, complectens. $2^{a}$ ed. Sumptibus Ioannis Baptistae Buysson. Lugduni, 2 tomos en IV.

357 La obra citada con el título abreviado: Antonio Pérez. Praelectiones, sive commentarios in libros novem Codicis Iustinianei, ha sido identificada como la obra: "Pérez, Antonio. 1740-1741. Praelectiones in duodecim E libros codicis justiniani imp: quibus leges omnes authenticae perpetua serie explicantur, mores hodierni inseruntur $E$ quid sit iuris antiqui. Apud Henricum Albertum Gosse \& Soc. Coloniae Allobrogum, 2 volúmenes.

358 La obra citada con el título abreviado: Manuel González Téllez. Commentaria perpetua in singulos textus quinque librorum Decretalium, ha sido identificada como la obra: *González Téllez, Manuel. 1673. Commentaria perpetua in singulos textus quinque librorum Decretalium Gregorii IX. Sumptibus Laurentii Arnaud, \& Petri Borde. Lugduni. 
Fagnanus $^{359}$ y Anacleto Reiffenstuel ${ }^{360}$-, obras de comentaristas de Derecho real inscritos en el mos italicus tardío -Francisco de Avilés, ${ }^{361}$ Juan de Matienzo, ${ }^{362}$ Alfonso de Azevedo, ${ }^{363}$ Alfonso

359 Tras consultar varios repertorios bibliográficos no ha sido posible identificar la obra citada bajo el título abreviado: Próspero Fagnanus. Commentaria in quinque libros Decretalium.

360 La obra citada con el título abreviado: Anacleto Reiffenstuel. Ius Canonicum universum clara methodo iuxta titulos quinque librorum Decretalium in quaestionum distributum, ha sido identificada como la obra: "Reiffenstuel, Anacleto. 1739. Ius Canonicum universum clara methodo iuxta titulos quinque Librorum decretalium in quaestiones $2^{a}$ ed. Joannis Andreae de la Haye. Ingolstadi.

361 La obra citada con el título abreviado: Francisco de Avilés. Nova diligens ac perutilis expositio seu legum praetorum ac indicum syndicatus totius Hispaniae Regni, ha sido identificada como la obra: *Avilés, Francisco de. 1581. Nova, diligens ac perutilis expositio capitum, seu legum praetorum, ac Iudicum sindicatus regnitotius hispaniae. Ex Officina Ildefonsi á Terranova \& Neyla. Salmanticae.

362 La obra citada con el título abreviado: Juan de Matienzo. In librum V Collectionis Legum Hispaniae commentaria, ha sido identificada como la obra: "Matienzo, Juan de. 1597. Commentaria Ioannis Matienzo regii Senatoris in Cancellaria Argentina reggni Peru in librum quintum recollectiones legum Hispaniae. Excudebat Petrus Madrigal. Mantuae Carpentanee.

363 La obra citada con el título abreviado: Alfonso de Azevedo. Commentariorum Iuris Civilis in Hispaniae Regias Constitutiones, ha sido identificada como la obra: *Azevedo, Alfonso de. 1583-1599. Commentarium Iuris Civilis in Hispaniae Regias Constitutiones. Excudebat Cornelius Bobardus. Salmanticae, 6 volúmenes. 
de Carbona, ${ }^{364}$ Francisco Carrasco del Saz ${ }^{365}$ y Gaspar de Hermosilla ${ }^{366}$-, obras de consiliaristas inscritos en el mos italicus tardío -Próspero Farinacio, ${ }^{367}$ Juan Bautista Valenzuela Velásquez ${ }^{368}$

364 La obra citada con el título abreviado: Alfonso de Narbona. Commentaria in tertiam partem Novae Recopilationis Legum Hispaniae, ha sido identificada como la obra: *Narbona, Alfonso de. 1624. Commentaria in tertiam partem Novae Recopilationis legum Hispaniae Alphonsi Narbona. Apud Didacum Rodriguez, Typ. Regium. Toleti.

365 La obra citada con el título abreviado: Carrasco Del Saz, Francisco. Interpretatio ad singulas Leges Novae Recopilationes Regni Castellae, ha sido identificada como la obra: 'Carrasco Del Saz, Francisco. 1620. Interpretatio ad aliquas recopilationis regni castellae. Apud Hieronimum A. Contreras. Hispali.

366 Tras consultar varios repertorios bibliográficos no ha sido posible identificar la obra citada bajo el título abreviado: Gaspar de Hermosilla. Notae, additiones et resolutiones ad glossas Legum Partitarum D. Gregorii Lopetii.

367 La obra citada con el título abreviado: Próspero Farinacio. Consilia sive responsa atque decisionum causarum criminalium, ha sido identificada como la obra: *Farinacio [o Farinacci], Próspero. 1649. Consilia sive Responsa atque decisiones causarum criminalium. Excudebat Phillipus Gamonetus. Colonia Allobrogum.

368 La obra citada con el título abreviado: Juan Bautista Valenzuela Velázquez. Consiliorum sive responsorum iuris, ha sido identificada como la obra: *Valenzuela Velázquez, Juan Bautista. 1634. Consilia sive iuris responsa. [S.n.]. Neapoli, 2 volúmenes. 
y Diego Ibáñez de Faría ${ }^{369}$-, obras de decisionistas inscritos en el mos italicus tardío -Antonio Gama, ${ }^{370}$ Juan Pedro Fontanella, ${ }^{371}$ Juan Bautista Larrea, ${ }^{372}$ Miguel Caldera, ${ }^{373}$ Juan Bautista de

369 La obra citada con el título abreviado: Diego Ibáñez de Faría. Additiones, enucleationes et Rotae ad librum primum (secundum)..., ha sido identificada como la obra: "Ibáñez de Faría, Diego. 1675. Additiones, observationes et nota ad libros variarum resolutionum illustrissimi ac reverendissimi D. Didaci Covarruvias A Leiva. [S.n.]. Lugduni.

370 La obra citada con el título abreviado: Antonio Gama. Decisiones Supremi Lusitaniae Senatus, ha sido identificada como la obra: *Gama, Antonio da. 1578. Decisiones supremi senatus invictissimi Lusitaniae Regis per Antonium à Gama regium senatorem olim cum doctissimis collegis decrete $\mathcal{E}$ nunc in lucem editae. Excudebat Emanuel Ioannes. Ulissippone.

371 La obra citada con el título abreviado: Juan Pedro Fontanella. Sacri Senatus Cataloniae decisiones, ha sido identificada como la obra: "Fontanella, Juan Pedro. 1639-1645. Sacri Regii Senatus Cathalonia decisiones. Ex Praelo, acaese Petri Lacavalleria. Barcinone, 2 volúmenes.

372 Juan Bautista Larrea. Novae Decisiones Granatensis. "Larrea, Juan Bautista. 1647-1648. Novarum decisionum sacri regii Senatus granatensis, regni Castellae. Haered. Petri Prost, Phillippi Borde, \& Laurentii Arnaud. Turnoni, 2 volúmenes.

373 Tras consultar varios repertorios bibliográficos no ha sido posible identificar la obra citada bajo el título abreviado: Miguel Caldera. Sacri regii criminalis Cathaloniae decisiones. 


\section{Luca, ${ }^{374}$ Cristóbal Crespi de Valldaura ${ }^{375}$ y Pari- zuela y Miguel Cortiada ${ }^{376}$-, obras de controver- sistas inscritos en el mos italicus tardío -José Yá- ñez Parladorio, ${ }^{377}$ Andrés Fachineus, ${ }^{378}$ Blas}

374 La obra citada con el título abreviado: Juan Bautista de Luca. Sacrae Rotae Romanae Decisiones, ha sido identificada como la obra: "Luca, Cardenal Juan Baustista de. 1759. Sacrae rotae romanae Decisiones, et sumomorum pontificum constitutiones recentissimae, Theatrum verita et justitae. Ex typographia Balleoniana. Venetiis.

375 La obra citada con el título abreviado: Cristóbal Crespi de Valdaura. Observationes illustratas decisionibus Sacri Supremi Aragonum Consiliis. Cruciatae E Regiae Audientiae Valentiae, ha sido identificada como la obra: *Crespi de Valldaura y Parizuela, Cristóbal. 1662. Observationes illustrata decisionibus sacri Supremi regii aragonum consilii supremi consilii sancta cruciata $\mathcal{E}$ regia audientia Valentina. Sumptibus Horatii Boissat \& Georgii nemeus. Lugduni, 2 volúmenes.

376 La obra citada con el título abreviado: Miguel Cortiada. Decisiones Reverendi Cancellarii et Sacri Regii Senatus Cathaloniae, ha sido identificada como la obra: *Cortiada, Miguel. 1714. Decisiones cancellarii et sacri regii senatus cathaloniae. Sumptibus Anisson, \& Pasuel. Lugduni, 2 volúmenes.

377 Tras consultar varios repertorios bibliográficos no ha sido posible identificar la obra citada bajo el título abreviado: José Yáñez Parladorio. Quotidianarum differentiarum sesquicenturia.

378 La obra citada con el título abreviado: Andrés Fachineus. Controversiarum iuris, ha sido identificada como la obra: "Fachineaus, Andreas. 1602. Controversiarum iuris libri decem: quibus omnes feré quaestiones praecipuae, ut sun iudiciales, contractuum, ultimarum voluntatum, feudales, criminales et aliae miscellanae mira brevitate et perspicuitate discutiutur. Apud Societatem Venetam. Venetiis. 
Flores Diez de Mena, ${ }^{379}$ José Vela, ${ }^{380}$ Juan del Castillo Sotomayor ${ }^{381}$ y Diego Cantera ${ }^{382}$, obras de alegacionistas inscritos en el mos italicus

379 La obra citada con el título abreviado: Blas Flores Díez de Mena. Recentiorum practicarum quaestionum iuris canonici $\&$ civilis ad praxim utriusque fori spectantium, ha sido identificada como la obra: *Flores Díez de Mena, Blas. 1609. Recentiorum practicarum quaestionum Iuris Canonici et Civilis ad praxim utriusque fori spectantium libri tres. Nunc denuo fideliter excusum et a plurimis, quibus scatebat, mendis repurgatum. Ex Officina Didaci à Cussio: a Costa de Nicolas Martin del Castillo librero. Salmanticae.

380 La obra citada con el título abreviado: José Vela. Dissertationes iuris controversi in Hispalensi Senatus, ha sido identificada como la obra: *Vela de Oreña, José. 1653 (1652). Dissertationum iuris controversi tamin Hispalensi quam Granatensi senatu secundus tomus. Apud Balthasarem de Bolibar: sumptibus Bernardi Martinez y Ioannis de Moya, bibliopolarum. Granatae.

381 La obra citada con el título abreviado: Juan del Castillo Sotomayor. Quotidianarum controversiarum iuris, ha sido identificada como la obra: *Castillo Sotomayor, Juan del. 1603. Quotidianarum controversiarum iuris liber primus...: in quo ususfructus singularis ettutilis tractatus continetur ... Ex officina Ioannis Gratiani apud viduam: a costa de Diego Guillen ... Compluti.

382 La obra citada con el título abreviado: Diego Cantera. Quaestiones criminales, ha sido identificada como la obra: *Cantera, Diego. 1589. Quaestiones criminales tangentes iudicem: acusatorem, reum, probationem, punitionem que delictorum. Excudebat Cornelius Bonardus. Salmantica. 
tardío -Pedro Díaz de Rivadeneyra Noguerol, ${ }^{383}$ Juan Bautista Larrea ${ }^{384}$ y Antonio de Castro ${ }^{385}$-, obras de tratadistas inscritos en el mos italicus tardío -Antonio Ayerve de Ayora, ${ }^{386}$ Luis de

383 La obra citada con el título abreviado: Pedro Diez de Rivadeneyra Noguerol. Allegationum iuris, ha sido identificada como la obra: "Diez de Rivadeneyra Nogueral, Pedro. 1656. Allegationum iuris: in quibus quam plures quaestiones summe necessariae in supremae Hispaniarum Curiae tribunalibus disceptatae ad praxim us umque forensem spectantes enuncleantur: opus novum...; cum duplici indice ... Ex Typographia Regia: a Costa de Manuel López mercader de libros. Matriti.

384 La obra citada con el título abreviado: Juan Bautista Larrea. Allegationes fiscales, ha sido identificada como la obra: "Larrea, Juan Bautista. 1642. Allegationum fiscalium. Lugduni: Sumptibus Petri Prost. Lugduni, 2 volúmenes.

385 La obra citada con el título abreviado: Antonio de Castro. Allegationes canonicae cum suis decisionibus, ha sido identificada como la obra: "Castro, Antonio de. 1689. Allegationes canonicae: cum sius decissionibus. Nunc vero in lucem aeditis, et noviter auctis, per don Ioannem de Castro Gallego. Ex Officina Bernardi de Villa-Diego, Typographo regio. Matriti.

386 La obra citada con el título abreviado:, Antonio Ayerve de Ayora. De bonorum partitionibus tractatum, ha sido identificada como la obra: *Ayerve de Ayora, Antonio. 1623. Tractatus de partitionibus bonorum communium inter maritum, et uxorem $\&$ filios ac haeredes eorum: et fructibus dividendis tam haereditatum, quàm bonorum maioratus inter successores, $\varepsilon$ pradecesores uxores... Apud Ioannem de Rueda typographum. Vallisoleti. 
Molina y Morales, ${ }^{387}$ Juan García de Saavedra, ${ }^{388}$ Nuño de Acosta, ${ }^{389}$ Ignacio Lassarte y Molina, ${ }^{390}$

387 Tras consultar varios repertorios bibliográficos no ha sido posible identificar la obra citada bajo el título abreviado: Luis de Molina y Morales. De hispanorum primogeniis.

388 La obra citada con el título abreviado: Juan García de Saavedra. De expensis et meliorationibus, ha sido identificada como la obra: *García de Saavedra, Juan. 1578. De expensis et meliorationibus, liber unus. Apud Antonium Sanchez a Leyva: a Costa de Blas de Robles. Compluti. La obra citada con el título abreviado: Juan García de Saavedra. De hispanorum nobilitate, ha sido identificada como la obra: *García de Saavedra, Juan. 1597. Tractatus De Hispanorum nobilitate et exemptione. Ex officina Ioannis Gratiani apud viduam: a Costa de Juan de Sarria. Compluti.

389 La obra citada con el título abreviado: Nuño de Acosta. De privilegiis creditorum tractatus absolutissimum, ha sido identificada como la obra: "Acosta, Nuño de. 1739. De privilegiis creditorum: tractatus absolutissimus in quo celebriores, $\mathcal{E}$ in uso forensi frequentiores quaestiones de praederentis creditorum discutiuntur, $\mathcal{E}$ salidissima doctrina resolvuntur. Sumptibus Haeredum Cramer et fratum Philibert. Genevae.

390 La obra citada con el título abreviado: Ignacio Lassarte y Molina. De decima venditionis $\mathcal{E}$ permutationis, quae alcavala nuncupatur, ha sido identificada como la obra: "Lassarte y Molina, Ignacio. 1589. De decima venditionis et permutationes, que Alcavala nuncupatur Liber unus. Tractatus quidem omnibus iuris operam dantibus tam in theoria, quàm praxis. Apud Toannem Gratianum. Compluti. 
José Mascardo, ${ }^{391}$ Francisco Carpio, ${ }^{392}$ Feliciano de
Solís, ${ }^{393}$ García Gironda, ${ }^{394}$ Diego Balero y Caxal,,${ }^{395}$

391 La obra citada con el título abreviado: José Mascardo. Conclusionum omnium probationum, ha sido identificada como la obra: "Mascardo, José [o Giuseppe Mascardi]. 1597. Conclusiones omnium probationum, ac quaestionum, quae in utroque foro quotidie versantur... [S.n.]. Augustae Tourinoram, 2 volúmenes.

392 La obra citada con el título abreviado: Francisco Carpio. De executoribus et commissariis testamentariis libri quatuor, ha sido identificada como la obra: *Carpio, Francisco del. 1638. De executoribus et commissariis testamentariis. Excudebat Ludovicus estipihan. Ursaone.

393 La obra citada con el título abreviado: Feliciano de Solís. De censibus quatuor libris, ha sido identificada como la obra: "Solís, Feliciano de. 1594. Commentarii de censibus, quatuor libris fere omnem materiam de censibus complectentes. Ex officina Joannis Gratiani defuncti: impensis Ioannis Sarriae. Compluti.

394 La obra citada con el título abreviado: García Gironda. Tractatus de explicatione privilegiorum, ha sido identificada como la obra: *Gironda, García de. 1617. Tractatus de explicatione privilegiorum. Apud Ludovicum Sanctium. Matriti. La obra citada con el título abreviado: García Gironda. Tractatus de gabellis cum additione diversorum tribunalium ad materiam pertinentium, ha sido identificada como la obra: *Gironda, García de. 1594. Tractatus de gabellis regibus Hispaniae debitis. Apud Viduam Petri Madrigal: a Costa de Estevan Bogia. Madriti.

395 La obra citada con el título abreviado: Diego Balero y Caxal. De decoctione debitorum fiscalium, ha sido identificada como la obra: *Bolero Cajal, Diego. 1675. De decoctione debitorum fiscalium, et eorum bonis curandis, et distrabendis, ut fisco, et creditoribus satisfiat, et de iurisalictione tribunalis de coitionum huius cuariae. Ex officina Lucae Antonii de Bealmar typographi. Matriti. 


\section{Alfonso de Olea ${ }^{396}$ Fernando Escaño, ${ }^{397}$ Manuel Román Valerón, ${ }^{398}$ Luis Postio, ${ }^{399}$ Hermenegildo}

396 La obra citada con el título abreviado: Alfonso de Olea. Tractatus de cessione iurium et actionum, ha sido identificada como la obra: *Olea, Alfonso de. 1752. Tractatus de cessione iurium et actionum: in quo insertae sunt suo loco, additiones seu resolutiones, cum sacrae Rotae romanae decisionibus ad hancce materiam facientibus. Typographia Balleoniana. Venetiis.

397 La obra citada con el título abreviado: Fernando Escaño. Deperfectione voluntatis testamento, ha sido identificada como la obra: *Escaño, Fernando de. 1665. Tractatus de perfectione voluntatis testamento requisita et de testamento perfecto ratione voluntatis... Apud Michaelem Aldabe... Hispali.

398 Tras consultar varios repertorios bibliográficos no ha sido posible identificar la obra citada bajo el título abreviado: Manuel Román Valerón. De transactionibus tractatum.

399 La obra citada con el título abreviado: Luis Postio. Tractatus de subhastatione, ha sido identificada como la obra: "Postio, Luis. 1652. De subhastatione: tractatus non superfluus, sed necessarius, $\mathcal{E}$ ad praxim aptatus, E ordinatus. Sumptibus Iohannis de Tournes. Genevae. La obra citada con el título abreviado: Luis Postio. Tractatus mandati de manutendo, ha sido identificada como la obra: "Postio, Luis. 1674. Sacrotae romanas decisiones ad tractarum mandati de manu tenendo. Ex Typographia' Marthael i Liberal, et Simonis Potin. Lyon. 


\section{de Roxas, ${ }^{400}$ Lorenzo Matheu y Sanz ${ }^{401}$ Melchor Meres, ${ }^{402}$ Tomás Sánchez, ${ }^{403}$ Agustín Barbosa, ${ }^{404}$}

400 La obra citada con el título abreviado: Hermenegildo de Roxas. Tractatus postbumus de incompatibilitate regnorum ac maioratum, ha sido identificada como la obra: *Aguila y Roxas, Fernando Alfonso del. 1738. Additae quaestiones de incompatibilitate regnorum \& maioratuum, ad Tractatum $d$. Hermenegildi de Roxas... quem in lucem editum vidit curâ E studio d. Francisci Ximenes del Aguila... ubi plura utilissima et noviter discursa in materia resolvuntur, E decisionibus tribunalium Hispaniae, maximè Granatensis senatus, comprobata, ad praxim utiliter inveniuntur. Sumptibus fratrum de Tournes. Coloniae Allobrogum.

401 La obra citada con el título abreviado: Lorenzo Matheu y Sanz.

Tractatus de re criminali, ha sido identificada como la obra: *Matheu y Sanz, Lorenzo. 1672. Tractatus de re criminali, sive controversiarum usufrequentium in causis Criminalibus, cum earum decissionibus, tàm in Aula suprema ac Hispana Criminum, quàm in summo senatu novi orbis. Editio tertia prioribus emendatior cum triplici indice controversiarum, jurium ac rerum locupletissimo. Sumptibus Anisson. Lugduni.

402 Tras consultar varios repertorios bibliográficos no ha sido posible identificar la obra citada bajo el título abreviado: Melchor Meres. De maioratus et meliorationibus Hispaniae.

403 La obra citada con el título abreviado: *Tomás Sánchez. De Sancto matrimonio sacramenti disputatio, ha sido identificada como la obra: "Sánchez, Thomas. 1614. Disputationum de sancto matrimonio sacramento. Apud Haeredes Martini Nuti et Ionannem Meurisiu. Antuerpiae.

404 La obra citada con el título abreviado: Agustín Barbosa. Opera, ha sido identificada como la obra: *Barbosa, Agustín. 1699. Opera Agustini Barbosae. Ed. novissima, ab authore recognita. Sumptibus Petri Borde, Joannis et Petri Arnaud. Lugduni. 


\section{Ascanio Tamburino, ${ }^{405}$ Francisco de Mosta- zo, ${ }^{406}$ Francisco Alfaro, ${ }^{407}$ Gaspar de Escalona y Agüero, ${ }^{408}$ Juan de Solórzano Pereira, ${ }^{409}$ José}

405 Tras consultar varios repertorios bibliográficos no ha sido posible identificar la obra citada bajo el título abreviado: Ascanio Tamburino. De iure abbatum.

406 La obra citada con el título abreviado: Francisco de Mostazo. Tractatus de Causis piis, ha sido identificada como la obra: "Mostazo, Francisco. 1686. D. D. Francisci a Mostazo... De causis piis in genere, et in specie Libri VIII: opus quidem perutile non solum judicibus y Visitatoribus Ecclesiasticis, verum etiam Secularibus... Tomus primus: diligenter recognitus, multisque mendis expurgatus... Nunc denvo in lucem prodit. Sumptibus Petri Borde, Joannis, y Petri Arnaud. Lugduni.

407 La obra citada con el título abreviado: Francisco Alfaro. Tractatus de officio fiscalis deque fiscalibus privilegiis, ha sido identificada como la obra: *Alfaro, Francisco de. 1606. Tractatus de officio fiscalis, deque fiscalibus privilegiis. Apud Ludovicum Sanchez. Vallisoleti.

408 Tras consultar varios repertorios bibliográficos no ha sido posible identificar la obra citada bajo el título abreviado: Gaspar de Escalona y Agüero. Arcae Limensis.

409 La obra citada con el título abreviado: Juan de Solórzano Pereira. Política Indiana, ha sido identificada como la obra: "Solórzano Pereira, Juan de. 1647. Política Indiana. $1^{a}$ Ed. Officina de Diego Diaz de la Carrera. Madrid. 


$$
\begin{aligned}
& \text { Veitia Linaje, }{ }^{410} \text { Matías Lagúnez, }{ }^{411} \text { Francisco } \\
& \text { Salgado de Somoza, }{ }^{42} \text { Gaspar de Villarroel, },{ }^{43}
\end{aligned}
$$

410 La obra citada con el título abreviado: José de Veitia Linage. Norte de la contratación de las Indias.., ha sido identificada como la obra: "Veitia Linage, José de. 1672. Norte de la contratación de las Indias Occidentales. J. F. de Blas. Sevilla.

411 La obra citada con el título abreviado: Matías Lagúnez. Tractatus de fructibus, ha sido identificada como la obra: *Lagunez, Matías. 1686. Tractatus de fructibus: titulo generali in quo selectiora, qua rem fructuariam pertinens iura expendutur difficilioraque referantur. Ex Typographia Melchioris Alvarez. Matriti, 2 volúmenes.

412 La obra citada con el título abreviado:, Francisco Salgado de Somoza. De regia protectione, ha sido identificada como la obra: *Salgado de Somoza, Francisco. 1626. Tractatus de regia protectione vi oppressorum appellantium à causis $\mathcal{E}$ iudicibus ecclesiasticis. Sumpt. L. Prost., haeredis Roville. Lugduni, 2 volúmenes. La obra citada con el título abreviado: Francisco Salgado de Somoza. Tractatus de supplicatione ad Sanctissimum, ha sido identificada como la obra: *Salgado de Somoza, Francisco. 1664. Tractatus de supplicatione ac Sanctissimum Aliteris et de earum retentione intermin senatu. $1^{a}$ ed. Sumptibus Lartentii Anissan. Lyancase. La obra citada con el título abreviado: Francisco Salgado de Somoza,. Labyrinthus creditorum, ha sido identificada como la obra: *Salgado de Somoza, Francisco. 1653. Labyrinthus creditorum concurrentium ad litem per debitorem communem inter illos causatam. Apud Iacobum Meursium. Antuerpiae, 2 volúmenes.

413 La obra citada con el título abreviado: Gaspar de Villarroel. Gobierno eclesiástico pacífico y..., ha sido identificada como la obra: *Villarroel, Gaspar de. 1656. Gobierno Eclesiástico Pacífico y Unión de los dos Cuchillos, Pontificio y Regio. Domingo García Morás. Madrid, 2 volúmenes. 


\section{Pedro Frasso, ${ }^{414}$ Antonio Joaquín de Rivadeneyra y Barrientos ${ }^{415}$ y Antonio José Âlvarez de Abreu ${ }^{416}-$, obras de prácticos inscritos en el mos italicus tar- dío -Gabriel de Monterroso y Alvarado, ${ }^{417}$}

414 La obra citada con el título abreviado: Pedro Frasso. De regio patronatu..., ha sido identificada como la obra: "Frasso, Pedro. 1677-1679. De regio patronatu: ac aliis nonnullis regaliis, regibus catholicis, in Indiarum Occidentalium Imperio, pertinentibus, quaestiones aliquae desumptae, et disputatae. In quinquaginta capita partitae. Ex Typographia Imperiali: apud Iosephum Fernandez á Buendia. Matriti, 2 tomos en 3 volúmenes.

415 La obra citada con el título abreviado: Antonio Joaquín Rivadeneyra y Barrientos. Manual compendio..., ha sido identificada como la obra: "Rivadeneyra y Barrientos, Antonio Joaquín de. 1755. Manual compendiado de el regio patronato indiano: para su mas facil uso en las materias conducentes á la práctica. Antonio Marin. Madrid.

416 La obra citada con el título abreviado: Antonio José Álvarez de Abreu. Víctima real legal..., ha sido identificada como la obra: *Álvarez de Abreu, Antonio José. 1726. Víctima Real legal, discurso único jurídico-bistórico-político sobre que las vacantes mayores y menores de las Iglesias de las Indias Occidentales, pertenecen a la corona de Castilla y León, en pleno, y absoluto dominio. En la Imprenta de Antonio Marin. Madrid.

417 La obra citada con el título abreviado: Gabriel de Monterroso y Alvarado. Práctica civil y criminal y instrucción de escrivanos, ha sido identificada como la obra: *Monterroso y Alvarado, Gabriel de. 1587. Practica civil y criminal, y instrucción de escrivanos. Por Pedro Madrigal: vendese en casa de Blas de Robles. Madrid. 
Gabriel Parexa de Quesada, ${ }^{418}$ Gómez Bayo ${ }^{419}$ y Jerónimo Fernández de Herrera y Villarroel ${ }^{420}$, obras de la Escuela española de Derecho natural -Alfonso de Castro ${ }^{421}$ y Luis de Molina ${ }^{422}$-, obras

418 La obra citada con el título abreviado: Gabriel Parexa de Quesada. Praxis de instrumentorum editione, ha sido identificada como la obra: "Pareja y Quesada, Gabriel. 1668. Praxis edendi, sive tractatus de universa instrumentorum editione. Editione novissima. Sumptibus Laurentii Anisson. Lugduni, 2 tomos en 1 volumen.

419 La obra citada con el título abreviado: Gómez Bayo. Praxis ecclesiastica et saecularis, ha sido identificada como la obra: *Bayo, Gómez. 1640 (1639). Praxís ecclesiastica et secularis: cartineus tres libros: primum de praxi, secundum de questionibus veriis, testium de collectanea doctorum... Ex officina Mieronimi Murillo...: expensis Andreae Calderon viduae Bibliopolae. Vallisoleti.

420 La obra citada con el título abreviado:, Jerónimo Fernández de Herrera y Villarroel. Práctica Criminal, ha sido identificada como la obra: "Fernández de Herrera Villarroel, Jerónimo. 1672. Practica Criminal instrucción... de substanciar las causas, con distinción de lo que... se debe observar, assi en los Consejos, y Sala, como en otros Tribunales superiores, y en los inferiores de juezes, pesquisidores, y ordinarios, por los escrivanos à quienes suelen cometerse, en que se notan muchas de las difucultades que se ofrecen en el todo, y en parte de ellas... En la Imprenta Real. Madrid.

421 Tras consultar varios repertorios bibliográficos no ha sido posible identificar la obra citada bajo el título abreviado: Alfonso de Castro. Opera, en 3 tomos.

422 La obra citada con el título abreviado: Luis de Molina. De iustitia et iure, ha sido identificada como la obra: *Molina, Luis de. 1614. De Iustitia et iure. R. P. Lodovici Molina. Excudebat Balthasar Lippius. Moguntia. 
De los libros surgen las leyes. Aproximación a los fondos ...

humanistas -Francisco Ramos del Manzano, ${ }^{423}$ Dionisio Godofredo, ${ }^{424}$ Francisco Amaya ${ }^{425}$ y Arnaldo Vinnio ${ }^{426}$.

8. Doctor José Rubio y Salinas Arzobispo de México, poseía fuentes canónicas - Concilio Tridentino-, textos de Legislación real-Recopilación de Indias-, obras de comentaristas de fuentes canónicas inscritos en el mos italicus tardío -Manuel

423 Tras consultar varios repertorios bibliográficos no ha sido posible identificar la obra citada bajo el título abreviado: Francisco Ramos del Manzano. De substitutionibus.

424 La obra citada con el título abreviado: Dionisio Godofredo. Su edición del Corpus Iuris Civilis, ha sido identificada como la obra: *Codicis justiniani D. N. Sacratissimi principis PP. AVG. Ripertita Pralectionis. Notis Dionysii Gothofredi. Postrena editio prioribus auctior E emendatior. 1624. Ex Typographia Jacobi Stoer. Colonia Allobrogum.

425 Tras consultar varios repertorios bibliográficos no ha sido posible identificar la obra citada bajo el título: Francisco Amaya. Observationum iuris libri tres.

426 La obra citada con el título abreviado: Arnaldo Vinnio. Institutionum imperialium commentarius academicus et forensis, ha sido identificada como la obra: *Vinnius, Arnoldus. 1699. In quatuor libros Institutionum imperalium Commentarius Academicis et Forensis Arnoldi Vinnii. Editio novissima et emendatissima. Sumptibus Anisson: et Ioannis Posuel. Lugduni, 2 volúmenes. 


\section{González Téllez, ${ }^{427}$ Próspero Fagnanus ${ }^{428}$ y Anacleto Reiffenstuel ${ }^{429}$ y Fray Pedro Murillo Velarde ${ }^{430}$, obras de decisionistas inscritos en el}

427 La obra citada con el título abreviado: Manuel González Téllez. Commentaria perpetua in singulos textus quinque librorum Decretalium, ha sido identificada como la obra: *González Téllez, Manuel. 1673. Commentaria perpetua in singulos textus quinque librorum Decretalium Gregorii IX. Sumptibus Laurentii Arnaud, \& Petri Borde. Lugduni.

428 Tras consultar varios repertorios bibliográficos no ha sido posible identificar la obra citada bajo el título abreviado: Próspero Fagnanus. Commentaria in quinque libros Decretalium.

429 La obra citada con el título abreviado: Anacleto Reiffenstuel. Ius Canonicum universum clara methodo iuxta titulos quinque librorum Decretalium in quaestionum distributum, ha sido identificada como la obra: *Reiffenstuel, Anacleto. 1739. Ius Canonicum universum clara methodo iuxta titulos quinque Librorum decretalium in quaestiones $2^{a} \mathrm{ed}$. Joannis Andreae de la Haye. Ingolstadi.

430 La obra citada con el título abreviado: Fray Pedro Murillo Velarde. Cursus Iuris Canonici Hispani et Indici, ha sido identificada como la obra: *Murillo Velarde, Fray Pedro. 1743. Cursus iuris Canonici, hispani, et indici in quo iuxta ordinem titulorum decretalium non solum canonica Decissiones afferuntur, sed in super additur, quod in nostro Hispania Regno, $\mathcal{E}$ in his Indiarum Provinciis Lege, consuetudine, privilegio, vel praxi statutum, $\mathcal{E}$ admissum est: opus sanè utile iuris studiosis... Ex Typographia Emmanuelis Fernandez. Matriti, 2 volúmenes. 
mos italicus tardío -Francisco de Peña, ${ }^{431}$ Cristóbal Crespi de Valldaura y Parizuela $a^{432}$ y Miguel Cortiada $^{433}$-, obras de controversistas inscritos en el mos italicus tardío -Tomás Carlevalio, ${ }^{434}$

431 La obra citada con el título abreviado: Francisco de Peña. Decisiones Sacrae Rotae Romanae, ha sido identificada como la obra: "Peña, Francisco de. 1650. Sacrae Rotae decani Recollectae decisiones per d.d., Didacum Antonium Frances de Urrutigoiti. Sumpt. Philippi Borde, Laurentii Arnaud \& Claudii Rigaud. Lugduni.

432 La obra citada con el título abreviado: Cristóbal Crespi de Valdaura. Observationes illustratas decisionibus Sacri Supremi Aragonum Consiliis. Cruciatae E Regiae Audientiae Valentiae, ha sido identificada como la obra: *Crespi de Valldaura y Parizuela, Cristóbal. 1662. Observationes illustrata decisionibus sacri Supremi regii aragonum consilii supremi consilii sancta cruciata E regia audientia Valentina. Sumptibus Horatii Boissat \& Georgii nemeus. Lugduni, 2 volúmenes.

433 La obra citada con el título abreviado: Miguel Cortiada. Decisiones Reverendi Cancellarii et Sacri Regii Senatus Cathaloniae, ha sido identificada como la obra: *Cortiada, Miguel. 1714. Decisiones cancellarii et sacri regii senatus cathaloniae. Sumptibus Anisson, \& Pasuel. Lugduni, 2 volúmenes.

434 La obra citada con el título abreviado: Tomás Carlevalio. Disputationum iuris variarum de iudiciis, ha sido identificada como la obra: *Carleval [o Carlevalio], Tomás. 1649. Disputationum iuris variarum ad interpretationem regiarum legum regni Castellae, et illis similium, tam ex iure neapolitano, quam ex utroque communi civili, et canonico. Apud Mariam Quignonii. Madriti, 2 tomos en 1 volumen. 


\author{
Juan del Castillo Sotomayor ${ }^{435}$ y Alfonso de \\ Olea ${ }^{436}$-, obras de tratadistas inscritos en el mos \\ italicus tardío -Manuel Román Valerón, ${ }^{437}$ To- \\ más Sánchez, ${ }^{438}$ Antonio Oliván, ${ }^{439}$ Nicolás
}

435 La obra citada con el título abreviado: Castillo Sotomayor, Juan del. Quotidianarum controversiarum iuris, ha sido identificada como la obra: *Castillo Sotomayor, Juan del. 1603. Quotidianarum controversiarum iuris liber primus...: in quo ususfructus singularis ettutilis tractatus continetur... Ex officina Ioannis Gratiani apud viduam: a costa de Diego Guillen... Compluti.

436 La obra citada con el título abreviado: Alfonso de Olea. Tractatus de cessione iurium et actionum, ha sido identificada como la obra: *Olea, Alfonso de. 1752. Tractatus de cessione iurium et actionum: in quo insertae sunt suo loco, additiones seu resolutiones, cum sacrae Rotae romanae decisionibus ad hancce materiam facientibus. Typographia Balleoniana. Venetiis.

437 Tras consultar varios repertorios bibliográficos no ha sido posible identificar la obra citada bajo el título abreviado: Manuel Román Valerón. De transactionibus tractatum.

438 La obra citada con el título abreviado: Tomás Sánchez. De Sancto matrimonio sacramenti disputatio, ha sido identificada como la obra: *Sánchez, Thomas. 1614. Disputationum de sancto matrimonio sacramento. Apud Haeredes Martini Nuti et Ionannem Meurisiu. Antuerpiae.

439 Tras consultar varios repertorios bibliográficos no ha sido posible identificar la obra citada bajo el título abreviado: Antonio Oliván. Tractatus de foro ecclesiae. 


\section{García, ${ }^{440}$ Francisco de Mostazo, ${ }^{441}$ Francisco Alfaro, ${ }^{442}$ Alfonso Pérez de Lara, ${ }^{443}$ Francisco}

440 Tras consultar varios repertorios bibliográficos no ha sido posible identificar la obra citada bajo el título abreviado: Nicolás García. De beneficiis tractatus.

$441 \mathrm{La}$ obra citada con el título abreviado: Francisco de Mostazo. Tractatus de Causis piis, ha sido identificada como la obra: "Mostazo, Francisco. 1686. D. D. Francisci a Mostazo... De causis piis in genere, et in specie Libri VIII: opus quidem perutile non solum judicibus y Visitatoribus Ecclesiasticis, verum etiam Secularibus... Tomus primus: diligenter recognitus, multisque mendis expurgatus... Nunc denvo in lucem prodit. Sumptibus Petri Borde, Joannis, y Petri Arnaud. Lugduni.

442 La obra citada con el título abreviado: Francisco Alfaro. Tractatus de officio fiscalis deque fiscalibus privilegiis, ha sido identificada como la obra: *Alfaro, Francisco de. 1606. Tractatus de officio fiscalis, deque fiscalibus privilegiis. Apud Ludovicum Sanchez. Vallisoleti.

443 La obra citada con el título abreviado: Alfonso Pérez de Lara. Tractatus de anniversariis et capellanis, ha sido identificada como la obra: *Pérez de Lara, Alfonso. 1608. De aniversariiis et capellaniis: libri duo: opus quidem, ut pium et practicabile, ita \& utile utroque foro versantibus, indicibus, advocatis, clericis, \& monachis, \& quibuscunque aliis piorum executoribus, nunc denuo ab ipso authore correctum \& auctum. Ex Typographia Ildephonsi Martini. Matriti. 


\section{Salgado de Somoza, ${ }^{444}$ Gaspar de Villarroel ${ }^{445}$ y Antonio Joaquín de Rivadeneyra y Barrientos ${ }^{446}-$.}

444 La obra citada con el título abreviado: Francisco Salgado de Somoza. De regia protectione, ha sido identificada como la obra: *Salgado de Somoza, Francisco. 1626. Tractatus de regia protectione vi oppressorum appellantium à causis $\mathcal{E}$ indicibus ecclesiasticis. Sumpt. L. Prost., haeredis Roville. Lugduni, 2 volúmenes. La obra citada con el título abreviado: Francisco Salgado de Somoza. Tractatus de supplicatione ad Sanctissimum, ha sido identificada como la obra: "Salgado de Somoza, Francisco. 1664. Tractatus de supplicatione ac Sanctissimum Aliteris et de earum retentione intermin senatu. $1^{a} \mathrm{ed}$. Sumptibus Lartentii Anissan. Lyancase. La obra citada con el título abreviado: Francisco Salgado de Somoza. Labyrinthus creditorum, ha sido identificada como la obra: "Salgado de Somoza, Francisco. 1653. Labyrintbus creditorum concurrentium ad litem per debitorem communem inter illos causatam. Apud Iacobum Meursium. Antuerpiae, 2 volúmenes.

445 La obra citada con el título abreviado: Gaspar de Villarroel. Gobierno eclesiástico pacífico y..., ha sido identificada como la obra: *Villarroel, Gaspar de. 1656. Gobierno Eclesiástico Pacífico y Unión de los dos Cuchillos, Pontificio y Regio. Domingo García Morás. Madrid, 2 volúmenes.

446 La obra citada con el título abreviado: Antonio Joaquín Rivadeneyra y Barrientos. Manual compendio de el Regio Patronato Indiano, ha sido identificada como la obra: *Rivadeneyra y Barrientos, Antonio Joaquín de. 1755. Manual compendiado de el regio patronato indiano: para su mas facil uso en las materias conducentes á la práctica. Antonio Marin. Madrid. 
De los libros surgen las leyes. Aproximación a los fondos ...

\section{Breves apuntes en relación a los libros de derecho en bibliotecas públicas indianas (Siglos XVI-XIX)}

Las bibliotecas públicas en Indias, empero no ser muy abundantes, también existieron. ${ }^{447}$ Aunque la historiografía se haya olvidado generalmente de ellas. A pesar de su importancia como vehículo de transmisión de los conocimientos contenidos en las obras bajo su custodia.

En el siglo XVIII se extendió la idea de la necesidad de contar con bibliotecas públicas. Apoyada por la existencia de la Biblioteca Palafoxiana (Puebla de los Ángeles) -de la que a continuación se tratará- y más concretamente por la apertura al público en Madrid de la Real Biblioteca (1712). Hasta ese momento algunos particulares y conventos habían franqueado el acceso a sus fondos de una manera graciosa. La concretación de esta idea vino de la mano de la expulsión de la Compañía de Jesús, con cuyos libros se comenzaron a proyectar nuevos repositorios. ${ }^{48}$

447 Torre Revello, El libro..., 1940. [Edición facsimilar. México: 1991], pp. 121-122, nota número 3. Tau Anzoátegui, Víctor; Eduardo Martiré. [1975]. Manual de historia de las instituciones argentinas. Macchi. Buenos Aires, p. 285.

448 Rípodas Ardanaz, 1989, p. 468. 
De las que debieron existir he podido hallar noticias de la Biblioteca del Colegio Imperial de Santa Cruz de Tlatelolco -la primera biblioteca de un centro educativo de la que se tiene noticia en la Nueva España ${ }^{449}$-, la Biblioteca Palafoxiana (Puebla de los Ángeles), la Biblioteca Turriana (ciudad de México), ${ }^{450}$ la Biblioteca de la Catedral de Santia-

449 José Luis Martínez. 2003. “Las primeras bibliotecas públicas en Nueva España”, en VV.AA. Biblioteca Palafoxiana. Artes de México (México, D.F.). P. 34. 68.

450 Esta biblioteca fue fundada "(...) en la Catedral de México, en 1788, con los libros donados a su fallecimiento por el canónigo doctor Luis Antonio Torres, (...). De esta Biblioteca existe un Catálogo impreso en Roma en 1761, cuya descripción es como sigue: Bibliotheca/ Turriana/ sive/ Catalogus Librorum/ pertinentium/ ad DD. Doctores/ D. Ludovicum, \& D. Cajetanum/ Antonium de Torres/ Frates/ Praebendatos Ecclesiae Mexicanae/ [viñeta]/ Romae M. DCC. LXI./ [filetes] Superiorum Facultate. Puede verse la reproducción de esta portada en Felipe Teixidor, Ex-libris y bibliotecas de México, cit., en Monografías bibliográficas mexicanas, cit., $n .^{\circ}$ 20. En la misma obra, pp. 364 a 372, se publica una noticia sobre sus orígenes. Esta biblioteca hoy se conserva en la $\mathrm{Na}$ cional de México. Al hacerse cargo de ella el interventor del gobierno en 1857, constaba de 12.295 volúmenes y 131 manuscritos. Los ex-libris de esta Biblioteca se reproducen en las pp. 32 y 33 de la citada obra; (...)." (Torre Revello, El libro..., 1940. [Edición facsimilar. México: 1991], p. 12, nota número 3). Millares Carlo dice de esta biblioteca que "(...) fue fundada por los hermanos [Ludovico y Cayetano Antonio de Torres] (...), en cumplimiento de la voluntad de su tío don Luis Antonio Torres. A la muerte (12 de diciembre de 1788) de don Luis Antonio, se incorporó a la de la Iglesia Catedral de México y fue abierta al público. Su último bi- 
go de Chile, ${ }^{451}$ la Biblioteca de la Universidad de México ${ }^{452}$ y la Biblioteca de la Compañía de Filipinas (Manila). ${ }^{453} \mathrm{~A}$ las que deben sumarse las biblio-

bliotecario fue don José María de Agreda y Sánchez; en 1857 pasó a la Biblioteca Nacional con 12.295 impresos y 131 manuscritos." (Millares Carlo, 1970, p. 39). Consúltese también: Iguiniz, Juan B.[autista]. 1940. "La Biblioteca Turriana”. Divulgación Histórica (México). Pp. 100-104. I/3 (15 de enero). [Reproducido en: Disquisiciones bibliográficas. México: El Colegio de México, 1943, pp. 262-268]. Millares Carlo, Agustín. 1978. Bibliografía de Andrés Bello. Fundación Universitaria Española. Madrid, p. 18.

451 En Chile, en el siglo XVIII, la más importante biblioteca particular fue la de Miguel de Alday y Aspée, Obispo de Santiago, la cual en 1755 contaba con 1095 volúmenes. De los cuales, 870 eran de temática jurídica. Tras su fallecimiento, y por expreso deseo suyo, fue donada a la Catedral de Santiago, convirtiéndose así en la primera biblioteca pública existente en el Reino de Chile (Cruz de Amenábar, Isabel. 1989. "La cultura escrita en Chile 1650-1820. Libros y bibliotecas”. Historia (Santiago de Chile), pp. 144-146. 24).

452 Esta biblioteca poseía, en 1784, 20.000 ejemplares (Elisa Luque Alcaide. 1970. La educación en Nueva España en el siglo XVIII. Consejo Superior de Investigaciones Científicas, Escuela de Estudios Hispano-Americanos de Sevilla (Publicaciones de la Escuela de Estudios Hispano-Americanos de Sevilla (CXCII). Sevilla, p. 65).

453 En 1804, la única librería pública que existía en Manila era la de la Compañía de Filipinas. Véase: AGN. Inquisición. Volumen: 1423. Folio 58 recto. 
tecas de las Reales Sociedades de Amigos del País ${ }^{454}$ -siendo la primera en abrir sus puertas en el continente americano la de La Habana, el 15 de julio de $1793^{455}-$, el intento que hubo de crear una biblioteca

454 José Luis Abellán. 1981. Historia crítica del pensamiento español. Tomo III. Del Barroco a la Ilustración (siglos XVII y XVIII). Espasa-Calpe. Madrid, "XVII. Las sociedades económicas de amigos del País”, pp. 733-747.

455 "En la segunda mitad del siglo XVIII contribuyeron eficazmente a difundir las ideas de la Ilustración las Reales Sociedades Económicas de Amigos del País, que las instalaron adecuadas a los fines que estas entidades perseguían, a saber: la ordenación económica y el fomento de la educación pública." (Millares Carlo, Agustín. 1970. "Bibliotecas y difusión del libro en Hispanoamérica colonial. Intento bibliográfico”. Boletín Histórico (Fundación John Boulton. Caracas). P. 33. 22 (enero)). Su primer bibliotecario fue José Arango, sucedido por Antonio Robredo (Torre Revello, El libro, ..., 1940. [Edición facsimilar. México: 1991], p. 122, nota número 3). "En 1793, a pocos meses de creada, la de La Habana cuenta con una biblioteca, formada de una manera sui generis - muy pocos libros propios y los demás dejados en depósito por los socios-, en un comienzo sólo accesible a sus miembros y, más adelante, con algunos recaudos, a lectores de todo tipo." (Rípodas Ardanaz, 1989, 469). Como dato de interés decir que esta Real Sociedad Económica tenía, en 1794, 1500 libros -de su propio fondo o en depósito de sus socios (Ibídem, pp. 475). En relación a la biblioteca de la Sociedad Económica de Amigos del País de la Habana, puede verse: Peraza Y Sarausa, Fermín. 1938. "La Biblioteca de la Sociedad Económica de Amigos, De 1793 a 1800”. Revista Bimestre Cubana (La Habana). Pp. 90-95. XLIII (julio-octubre). (Citado en: Torre Revello, El libro, ..., 1940. [Edición facsimilar. México: 1991], p. 122, nota número 3). 


\section{pública en Lima ${ }^{456}$ y en La Plata ${ }^{457}$ y las bibliotecas públicas creadas con los fondos bibliográficos ex- propiados a la Compañía de Jesús tras su expulsión en 1767. Así como las bibliotecas populares que se}

456 "Sobre el intento de creación de una biblioteca pública en Lima a fines del siglo XVIII, véase Manuel Mendiburu, Apuntes históricos, pp. 71 a 74, Lima (manejamos un ejemplar sin portada), donde glosa una carta del año 1758, dirigida por el ilustre escritor peruano Llano Zapata al arzobispo de Charcas, Cayetano Marcellano y Agramont, en donde dice, que en Lima, en manos de particulares habia bibliotecas "superiores a las que habia visto en los colegios de Sevilla que tenían bibliotecas de conocida fama; y que en Lima se hallaban y pagaban bien libros interesantes, que no se conocían en España o eran más escasos. Mencionaba muchisimas obras de primer orden en diversos idiomas que se encontraban en Lima"." (Torre Revello, El libro, ..., 1940. [Edición facsimilar. México: 1991], p. 122, nota número 3).

457 Manuel Azamor y Ramírez, Obispo de La Plata, muerto en 1796, legó en su testamento su biblioteca a la Iglesia, para “"(...) la educación pública y enseñanza."." (VV.AA. 1997. Biblioteca Nacional Argentina. Prólogo Oscar Sbarra Mitre. Manrique Zago, imp. Buenos Aires, p. 48). No obstante, “(...), las mandas del testamento de Azamor, asi como el plan del virrey Vértiz de formar una biblioteca anexa al Real Colegio de San Carlos, como se explica en su Memoria de 1784, apenas comenzaban a tomarse en cuenta para ser llevadas a cabo (aunque sin mucho entusiasmo) cuando la invasión inglesa de 1806 dejó el proyecto para una mejor oportunidad." (Ibidem, p. 48). Fue ya en la época independiente cuando se creó la actual Biblioteca Nacional de Argentina (Ibídem, p. 48). 
ordenaron crear en Cuba, Puerto Rico y Filipinas en el siglo XIX. ${ }^{458}$

\section{La biblioteca Palafoxiana}

La figura de Juan de Palafox y Mendoza (1600-1656), fundador de la Biblioteca Palafoxiana en Puebla de los Ángeles, ha sido siempre atrayente para la historiografía americanista. ${ }^{459}$ Noveno

458 Archivo Histórico Nacional (Madrid) -en adelante AHN-. Ultramar. Legajo 339. Expediente 13/1870. AHN. Ultramar. Legajo 165. Expediente 37/1880. AHN. Ultramar. Legajo 274. Expediente 28/1881. AHN. Ultramar. Legajo 165. Expediente 9/1883. AHN. Ultramar. Legajo 339. Expediente 47/18871889. AHN. Ultramar. Legajo 162. Expediente 29/1889-1890. AHN. Ultramar. Legajo 257. Expediente 14/1895.

459 En relación a la Biblioteca Palafoxiana de Puebla, además de los trabajos que se irán citando a lo largo de este apartado, pueden consultarse: Iguiniz, Juan B.[autista]. 1913. "La Biblioteca Palafoxiana de Puebla”. Anales del Museo de Arqueología, Historia y Etnografía (México). Pp. 289-300. V. "La Biblioteca Palafoxiana. Descripción de la nueva biblioteca de los Reales y Pontificios Colegios de San Pedro y San Juan de la Puebla de los Angeles, 1773”. 1942. Memorias de la Academia Mexicana de la Historia (México). Pp. 388-397. I/4 (octubre-diciembre). Torre [Villar], Ernesto de la. 1960. "Nuevas aportaciones sobre la Biblioteca Palafoxiana". Boletín de la Biblioteca Nacional (México). Pp. 35-66. XI/1 (enero-marzo). Castro Morales, Efraín. 1962. "La fundación de la Biblioteca Palafoxiana". Boletín de la Biblioteca Nacional (México). Pp. 18-31. XI/1 (enero-junio). VV.AA. 2003. Biblioteca Palafoxiana. Artes de México (México, D.F.). 68 . 
De los libros surgen las leyes. Aproximación a los fondos ...

Obispo de la dicócesis de Puebla de los Ángeles en el Virreinato de la Nueva España, fue además Capellán y Limosnero Mayor de la Emperatriz María de Austria, hermana de Felipe IV. Arzobispo de México; del Consejo de Su Magestad en el Real de las Indias y Supremo de Aragón; Visitador General, Virrey y Gobernador y Capitán General de la Nueva España, Presidente de su Real Audiencia y, al final de sus días ya de regreso en la Península, Obispo y Señor de Osma. Títulos y cargos a los que hay que sumar su faceta como bibliógrafo, poeta, autor de obras religiosas y de textos políticos, legislador, etcétera.

La Biblioteca Palafoxiana fue erigida por escritura pública el 5 de septiembre de 1646. Palafox y Mendoza la sufragó íntegramente de su peculio, contando con aproximadamente 5000 volúmenes de cánones, leyes, filosofía, medicina y buenas letras. Deseó que fuera una librería pública ya que "(...) había considerado que era de utilidad y conveniente que bubiese una (...) en la ciudad, donde todas las personas y en especial los eclesiásticos seculares y regulares, así como los cursantes y pasantes pudieran estudiar, por la gran falta de libros que se tenian que traer de lugares muy distantes, además de la escaséz de imprentas y papel". La biblioteca fue instalada en el Colegio Seminario de San Pedro, por él fundado 
el 22 de agosto de $1644 .{ }^{460} \mathrm{Su}$ actual fábrica data del siglo XVIII, siendo iniciada por la iniciativa del Obispo de Puebla de los Ángeles Francisco Fabián y Fuero, quien donó además a la misma su colección personal de libros. ${ }^{461}$

460 Ibídem, capítulo III.

461 Efraín Castro Morales. 1981. La Biblioteca Palafoxiana de Puebla. Editorial del Gobierno del Estado de Puebla, Subsecretaría de Cultura. Puebla, capítulos I, II, IV y V. "Algunos de los motivos para su fundación también los hizo patentes en los puntos de las "Instrucciones para este Obispado de la Puebla y sus gobernadores, por ausencia que hago a los Reinos de España, año de 1649”. Aquí refirió que lo impulsó a donar su biblioteca la falta de libros que habia para estudiar, pues se "van consumiendo los que hay en estas provincias, parte con la polilla que aquí los maltrata mucho, parte con venderlos para desacerlos en cartones y para chocolate $y$ otras cosas que no perdonan, tal vez, ni a los libros sagrados y me ha obligado a prohibirlo con censuras", así como por la falta de imprentas, escaso comercio y la falta de libros útiles y dignos de conservarse, además de que "en partes tan remotas pueden ser muy necesarios en la turbación de las opiniones a que está expuesta la inteligencia bumana y accidentes de los tiempos, pues suelen suceder en los públicos estados de los Reinos controversias generales y despertarse cismas y división, y asi será conveniente conservar las librerías y donde no bubiere fundarlas. Finalmente señalaba que, por el hecho de haber fundado los colegios, creyó conveniente para sus estudiantes que bubiese una biblioteca donde "puedan en todo género de facultades y ciencias aprender y ejercitarse sin costa y comodidad y utilidad común”." (Ibídem, capítulo IV). La Biblioteca se instaló en su nuevo emplazamiento, un gran salón en el Real Seminario Palafoxiano, en 1773. Situado "(...) entre los Colegios de San Pedro y San Juan y el gran jardin que se extendía hacia el sur, limitando por el Palacio Episcopal y el Colegio de San Pablo, (...)." (Ibídem, capítulo V). 
De los libros surgen las leyes. Aproximación a los fondos ...

Los fondos de la Biblioteca quedaron completos tras el paso del Obispo Fabián y Fuero por la Diócesis poblana -prelado al que se debe también la redacción de unas interesantes Ordenanzas para el uso de la Palafoxiana (1763)-.Tanto que según Mariano Fernández de Echeverría y Veytia "(...) "quedó -(...)- tan abastecida y completa, que no tiene igual en el reino y aun en España serán pocas (fuera de las reales) las que puedan competirla, en el conjunto de sus circunstancias"." 462

Melchor Ocampo que, tras una visita, escribió en 1836 una descripción de la Biblioteca Palafoxiana, afirmó que por esas fechas los fondos ascedían a 12,536 volúmenes de las más variadas materias -expositores y Santos Padres; Biblia; ascéticos; sermones; catequistas; Historia; gramáticos, anticuarios y poetas; retóricos y oradores; Geografía y matemáticas; Medicina e Historia natural; Filosofía; Ética y Política; Teología dogmática y polémica; Teología escolástica; Teología moral; litúrgicos y ritualistas; biógrafos; Historia monástica; intérpretes de Derecho canónico; Derecho canónico; alegaciones de Derecho; Derecho de Indias; Derecho español; De-

462 Mariano Fernández de Echeverría y Veytia. 1962-1963. Historia de la Fundación de la Ciudad de la Puebla de los Ángeles en la Nueva España, su descripción y presente estado. Altiplano. Puebla. (Citado en: Castro Morales, 1981, capítulo VII ). 
Complejidad y materialidad: reflexiones del Seminario del ...

recho civil; y periódicos científicos, literarios y políticos-; y en varios idiomas -Latín, Español, Francés, Italiano, Portugués, Griego, Español-Latín, Italiano-Francés, Griego-Latín, Latín-Francés, FrancésCastellano, Hebreo-Latín, Francés-Castellano e Italiano, Japonés, Mexicano, Huasteco, Mixteco, Italiano-Castellano y Mexicano-Castellano-. ${ }^{463}$

De los 12,536 volúmenes, 1815 eran de obras de jurisprudencia. Dividiendose de la siguiente manera: intérpretes de Derecho canónico -271-, Derecho canónico -593-, alegaciones de Derecho -93-, Derecho de Indias -146-, Derecho español -175- y Derecho civil -537-. La Biblioteca únicamente tenía 22 manuscritos, que eran todos de Derecho, exceptuando un lunario perpetuo para Puebla de los Ángeles.

Tras la independencia de México, la Biblioteca fue enriquecida con nuevas donaciones. Y en 1862 fue abierta al público con el nombre de Biblioteca Pública del Estado. A mediados del siglo XIX se le sumó la biblioteca del que fuera Obispo de Puebla de los Ángeles Francisco Pablo Vázquez. La cual ascendía a 11,000 volúmenes. El Prelado "(..), en 1835, tenía pensado donar para fundar una biblioteca pública, cediendo más de trece mil volúmenes. Sin embargo, la si-

463 Melchor Ocampo. 1901. Obras Completas. F. Vázquez, Editor. México. (Citado en: Castro Morales, 1981, capítulo VIII ). 
De los libros surgen las leyes. Aproximación a los fondos ...

tuación política y otros diversos eventos impidieron cumplir su deseo al obispo Vázquez, que falleció el 7 de octubre de 1847. Los libros que babía reunido fueron adquiridos, a sus albaceas, por el canónico José Francisco de Irigoyen en 1850, para cederlos a la Biblioteca Palafoxiana (...)". 464

\section{Reflexiones finales}

De todo lo expuesto se deduce que el estudio de los libros permite saber qué fue lo que leyeron y estudiaron los habitantes de Indias, en materia jurídica, entre los siglos XVI y XIX.

Revisado el contenido jurídico de las bibliotecas particulares y públicas novohispanas relacionadas se constata la presencia de las siguientes tendencias jurídicas: ediciones de fuentes romanas, ediciones de fuentes canónicas, cuerpos de legislación real, glosadores, comentaristas, mos italicus tardío (siglos XVI al XVIII), escuela española del Derecho natural, humanismo jurídico, iusnaturalismo racionalista, literatura jurídica crítica del Derecho vigente, libros de instituciones de Derecho patrio o nacional, literatura jurídica práctica,

464 Ibídem, capítulo VIII. 
Complejidad y materialidad: reflexiones del Seminario del ...

jansenismo-antijansenismo y probabilismo-probabiliorismo.

Puede decirse, por tanto, como primera afirmación, que el Ius commune tuvo una gran presencia en las mismas. Presencia que, sin lugar a dudas, contribuyó al desarrollo normativo del sistema jurídico indiano.

Producto de la importancia que la gran mayoría de los juristas novohispanos -y aun de otras latitudes indianas- dieron al Derecho común es la notable abundancia en sus bibliotecas de obras de "consejos y decisiones y repeticiones, lecciones y meditaciones".

Por poner un único ejemplo de lo dicho, en la biblioteca de Antonio Martínez Luján de Vargas, Oidor de la Real Audiencia de Charcas (desde el 26 de agosto de 1683), "(...), de (...) 890 obras -dedicadas en buena parte al derecho romano y canónico- un $27 \%$ se halla constituido por comentarios, interpretaciones, adiciones, observaciones, cuestiones, controversias, decisiones, consultas, consejos, alegaciones y conclusiones" 465

No obstante la tendencia representada por los comentaristas decayó a partir del siglo XVI, debido a varias causas. Ludovico Antonio de Muratori criticó en Defectos de la jurisprudencia a la corriente

465 Rípodas Ardanaz, 1975, p. 537, p. 507 y p. 537 -respectivamente-. 
De los libros surgen las leyes. Aproximación a los fondos ...

bartolista preponderante en la literatura jurídica desde el siglo XVI, reflejando al mismo tiempo el nuevo cuño de las obras del mos italicus escritas con posterioridad al 1500. El Humanismo censuró al Derecho común desde fines del siglo XV, a pesar de lo cual continuó el predicamento de la corriente bartolista. Caracterizada por acudir a la communis opinio, aunque con cariz práctico. Ello provocó el surgimiento de trabajos jurisprudenciales apartados de propósitos teóricos, así como del desarrollo del estudio directo sobre los textos jurídicos del Derecho romano.

Esta “(...) literatura bartolista posterior al 1500 muestra una declinación del género de comentarios a los textos justinianeos y el auge de comentarios al derecho real, y la aparición, o en algunos casos, el fortalecimiento de obras de consilia, responsa, allegationes, quaestiones, controversiae, praxis, $y$ tractatus.". Además de por su carácter práctico, la literatura jurídica del Derecho común posterior al 1500, recibió la influencia del Humanismo jurídico y de la Neoescolástica hispana. Extendiéndose a Indias. De acuerdo con Barrientos Grandón, la jurisprudencia indiana fue "(...) marcadamente bar- 
Complejidad y materialidad: reflexiones del Seminario del ...

tolista, aunque no sin alguna influencia bumanista y neotomista". 466

Con todo, junto a las obras de los comentaristas, figuran otras que rechazan la abundancia y uso indiscriminado de consejos, decisiones, repeticiones, lecciones y meditaciones, al considerar que alejaban al jurista de la fuente primigenia a la que debía aspirar. Extraviándolo al mismo tiempo en un laberinto de opiniones estériles.

Los pareceres de Francisco Bermúdez de Pedraza expresados en su Arte legal, el Arte real de Zevallos, las Empresas de Saavedra Fajardo o el Theatrum del Cardenal de Luca, anticiparon el notorio repudio

466 Luis Antonio Muratori. 1794. Defectos de la jurisprudencia.

Traducción del lic. Vicente María de Tercilla. Madrid, pp. 25-26. Citado en: Barrientos Grandón, Javier. 1992. La cultura jurídica en el Reino de Chile. Bibliotecas de ministros de la Real Audiencia de Santiago (S. XVII-XVIII). Escuela de Derecho, Universidad Diego Portales (Cuadernos de análisis jurídicos. 1. Serie publicaciones especiales. Diciembre de 1992). Santiago, Chile, p. 25. 
que a este género de obras se tuvo a lo largo del siglo ilustrado. ${ }^{467}$

La aceptación de esta opinión generalizada, se puso de manifiesto, por ejemplo, en las bibliotecas de los funcionarios de la Real Audiencia de Charcas, donde los "consejos y decisiones y repeticiones, lecciones y meditaciones" redujeron su presencia, al igual que sucedió en las de los ministros de la Real Audiencia de Chile. No obstante, y a pesar del alu-

467 "Hase llegado a tiempo tan caduco, que si interpretamos una ley, sino la adornamos del aparato, de opiniones, y authoridades nos parece, que no se ha cumplido con nuestro instituto; siendo cierto, que en las questiones y entendimientos de leyes opinativas, no està la resolucion dellas en el mayor, ò menor numero de Doctores, sino en los mas solidos motivos, como resolvieron Ioan Andres, y Barbacias. De otra manera la Iurisprudencia no tendria estabilidad, sino serie deambulatoria hasta el fin del siglo: porque la que oy es mas commun opinion, mañana es menos cómun, segun la variedad de los libros que cada dia salen: (...).” (Bermúdez de Pedraza, Francisco. 1612. Arte legal para estudiar la iurisprudencia. Con la paratitla, y exposicion á los titulos de los quatro libros de las Instituciones de Iustiniano. Por el Licenciado Francisco Bermudez de Pedraça, Abogado en los Consejos de su Magestad. Dirigida a Don Ivan de Acuña Marques de Valle, Presidente de Castilla. Emprenta de Antonio Rodríguez. Salamanca, "Que la verdadera interpretación de las leyes, no consiste en juntar opiniones de Doctores, sino inquirir el animo del Legislador. Cap. XV”, p. 129). "Los Glossadores de las leyes en la inteligencia dellas han incurrido en algunos errores haziendolas mas difficultosas con sus varios entendimientos, no teniendo difficultad, y siendo facil expedicion." (Ibidem, "De los errores de los interpretes en la inteligencia de las leyes. Cap. XX”, pp. 151-153). 
Complejidad y materialidad: reflexiones del Seminario del ...

dido repudio, continuaron circulando algunas impresiones de los siglos XVI y XVII del Corpus Iuris civilis -entero o parcialmente- y del Decreto de Graciano -acompañados en ambos casos de glosas-. Dichas arremetidas fructificaron finalmente $y$, de manera progresiva, la literatura jurídica fue perdiendo su antigua preeminencia, asistiéndose entonces al cambio de un Derecho de juristas -como el de siglos precedentes- a un Derecho legislado.

En el siglo XVIII abundaron en las bibliotecas indianas las obras de Derecho patrio, reflejo del deseo manifestado por la Corona de primar el Derecho real sobre el Derecho romano. Puesto que eran las normas del primero las utilizadas en los tribunales. De igual forma, en la decimoctava centuria, los libros de Derecho canónico se caracterizaron por su marcado regalismo.

La importancia de muchas de las obras citadas a lo largo de esta investigación radica en haber cumplido, en su momento histórico, las siguientes funciones dentro del sistema jurídico indiano: proporcionar el puente para pasar de la norma general al caso particular; posibilitar la enseñanza del Derecho al suministrar formación jurídica y orientación profesional a los interesados en la práctica forense; e influir decisivamente en los códigos de las naciones independientes americanas al ayudar a la formación de un substrato jurídico común. Del 
De los libros surgen las leyes. Aproximación a los fondos ...

mismo modo, una de las causas que denota la trascendencia de toda esta producción literario-jurídica se encuentra en el hecho de que, dado que en muchas ocasiones los legisladores tuvieron que legislar sobre aspectos no contemplados por el Derecho castellano, se hubo de recurrir a la doctrina de los autores para poder después estatuir en temas tales como el Derecho de conquista, la evangelización de los naturales, la capacidad racional de los mismos y la forma más adecuada para su gobierno. Igualmente, y como utilidad para los especialistas actuales, el conocimiento de la literatura jurídica europea e indiana posibilita la comprensión de la aplicación del Derecho en los tribunales indianos, así como el acercamiento a las transformaciones sufridas por la legislación indiana a lo largo del tiempo.

No me resisto a terminar esta reflexión sin citar un aforismo escrito por el Obispo Palafox y Mendoza, relativo al valor de los libros como herramienta efectiva contra la ignorancia y el abatimiento y que refleja, como pocos, el valor del ejemplar impreso o manuscrito como objeto mágico: "Ni al soldado le han de faltar armas, ni al sacerdote libros. A mi me parece que el que se balla en un beneficio sin libros, se halla en una soledad sin consuelo, en un monte sin compañia, en un camino sin báculo, en unas tinieblas sin guía, entre muchas pasiones sin defensor ni remedio". 


\title{
El comercio de libros en Latinoamérica colonial: aproximación al estado de la cuestión (siglos XVI-XVIII)
}

\author{
PEDRO RUEDA RAMÍREZ
}

\section{Reflexión inicial}

○os estudios recientes están revisando notable-

mente nuestros conocimientos sobre el impacto del libro, la escritura y la lectura en el mundo moderno. Los diferentes enfoques se preguntan sobre elementos clave de los fenómenos culturales, desde la reflexión sobre la aparición del espacio público hasta debates sobre la revolución lectora en diferentes momentos. Estos trabajos nos llevan a terrenos que permiten cuestionar la interpretación tradicional ligada a los éxitos y los avances centrados en las grandes obras, los autores y la acumulación de materiales para la historia de la cultura del 
Complejidad y materialidad: reflexiones del Seminario del ...

siglo pasado. Esta visión clásica alimentó la historia literaria y sostuvo una interpretación filosófica de lo cultural que, en lo que aquí nos interesa, resulta más una rémora que un estudio renovado basado en investigaciones documentales e interpretaciones de los procesos culturales de transformación y cambio propios del mundo moderno. La apertura de miras de la historia socio-cultural (o culturo-social), la amplitud y variedad de planteamientos de la historia intelectual renovada y tantos otros aspectos están haciendo posible el desarrollo de una historiografía que permite plantearse, una vez más, los fenómenos culturales en su conjunto (Clegg, 2001; Calvo, 2003).

El estudio del comercio del libro es un ámbito de la historia del libro poco trabajado, aunque existen antecedentes interesantes y trabajos innovadores que tratan del tráfico de libros. El negocio de venta en librerías ha centrado parte de los intereses de los investigadores, pero los mecanismos de puesta en circulación del libro son diversos y necesitan de herramientas metodológicas más variadas. En realidad en este terreno los diferentes enfoques convergen en una labor de síntesis dado el carácter multidisciplinar del tema. Es posible enfocar el estudio desde la historia económica (negocios, redes familiares y actividad económica, sistemas de compra-venta y regulación del mercado, impuestos so- 
El comercio de libros en Latinoamérica colonial ...

bre el libro, etcétera) hasta la historia de las ideas, pasando por toda la variedad de enfoques de la historia de la imprenta y la bibliografía material, la historia de enfoque antropológico y social o la historia literaria y textual. En todos estos terrenos el comercio del libro resulta un elemento esencial que permite comprender con mayor acierto el papel del libro y la lectura en las sociedades del mundo moderno. El libro abierto, en uso en manos del lector, necesita de una elaboración previa y una circulación para llegar a sus manos. Estos libros cerrados, en circulación, recorriendo distancias para lograr posicionarse en el mercado y alimentar los intereses lectores son los que aquí nos interesan. Se trataba de impresos (o manuscritos, de los que hay menos pistas), dispuestos en resmas o encuadernados. Eran objetos de cambio en una transacción comercial o bien producto de un intercambio amistoso. De hecho, los archiveros y bibliotecarios se acercan cada vez más a estos estudios de historia del libro y el comercio para lograr una comprensión más certera de la formación de sus colecciones, construir mejores referencias de las marcas de propiedad y entender los fenómenos que dieron origen a los fondos y colecciones de la edad moderna que son custodiados como un bien patrimonial. En cierto modo, el despegue del interés patrimonial en Latinoamérica y la mejora de la legislación encargada 
Complejidad y materialidad: reflexiones del Seminario del ...

de proteger los bienes está obligando a tomar medidas (García, 2001).

Un ejemplo de la tendencia a entreverar caminos de investigación en estos asuntos puede seguirse en las actas de los coloquios El Libro antiguo español, iniciados en 1986 y de los que han sido publicados siete hasta el celebrado en 2002. De esta iniciativa surgieron dos entidades notables, por una parte la Sociedad Española de Historia del Libro (actualmente englobada en el Seminario de Estudios Medievales y Renacentistas de la Universidad de Salamanca) y la Asociación Española de Bibliografía. En el año 2000 se fundó otra entidad, el Instituto de Historia del Libro y de la Lectura, que ha desplegado una actividad editorial notable (actas, monografías y la revista Syntagma). Las bases de las investigaciones, aunque aún en trance de consolidarse, tienen en estas entidades una visibilidad mayor, con diferencia, que la que le han proporcionado los departamentos de ciencias y técnicas historiográficas de las facultades de letras o los departamentos de bibliografía o de biblioteconomía. Éstos dedicados, en buena medida, aunque hay notables excepciones, a una erudición formal acorde a las necesidades meramente académicas y con un nulo compromiso o intervención en otras áreas de conocimiento o en una responsabilidad social o de difusión del patrimonio bibliográfico. Aunque, afortunadamente, hay pro- 
El comercio de libros en Latinoamérica colonial ...

yectos e iniciativas ligados a la digitalización y catalogación de carácter institucional como el Catálogo colectivo del patrimonio bibliográfico, tanto el desarrollado por el Ministerio de Cultura español como los catálogos patrimoniales de las comunidades autónomas (Carrato Mena, 2006), sin olvidar otros proyectos globales de carácter interestatal que, nos tememos, están en un momento de escaso desarrollo a pesar del decorado institucional en el que se sustentan, como ABINIA y otros.

Varias de las líneas de trabajo posibles aparecen en algunas de las revistas y colecciones disponibles hoy en día. Las comentaremos muy brevemente. La primera en el tiempo fue la Biblioteca del libro de la Fundación Germán Sánchez Ruipérez, le siguió la serie Instrumenta Bibliologica de Arco Libros, las colecciones de Ollero \& Ramos que permitieron la traducción de obras clave de la bibliografía material y actualmente está desarrollando una actividad intensa la editorial Trea. En cuanto a las revistas convendría recordar la ya citada Syntagma, la revista Signo. Revista de Historia de la Cultura Escrita iniciada en 1994 en Alcalá de Henares y la revista Litterae. Cuadernos sobre cultura escrita de la Universidad Carlos III de Madrid. Más recientemente contamos, desde 2005, con la revista Cultura escrita y sociedad con una visión integradora de la lecto-escritura y una notable calidad y diversidad de enfo- 
Complejidad y materialidad: reflexiones del Seminario del ...

ques en los contenidos. Estos coloquios, revistas y entidades han permitido enlazar investigaciones de procedencia variada y han dado buena cuenta de la presencia de numerosos trabajos de gran calidad desde ámbitos muy heterogéneos. En cualquier caso, la dispersión sigue siendo considerable y los trabajos de todo tipo no han logrado una visibilidad suficiente ni cuentan con un peso académico destacado. A esto se suma la reducción generalizada del peso de las asignaturas de historia del libro, de las bibliotecas y de la lectura en los nuevos planes de estudio de biblioteconomía en España, puesto en marcha paulatinamente a raíz de las necesidades del Espacio Europeo de Educación Superior.

\section{La escritura, el libro y la lectura en el mun- do colonial}

La historia del libro ha tenido un amplio desarrollo y una repercusión notable entre los historiadores españoles a partir, sobre todo, de los años ochenta. La influencia de la historiografía francesa se hizo notar de inmediato y fue la salida de $L$ 'apparition du livre de Lucien Febvre y Henri-Jean Martin, en 1958, la que permitió que se iniciaran los estudios renovados sobre la historia del libro, su producción y consumo (López, 1984; López-Vidriero, 2000). El estudio total del libro en una ciudad (posesión, producción, venta, etcétera) o de la pose- 
El comercio de libros en Latinoamérica colonial ...

sión del libro en los distintos segmentos sociales se convirtió en un objetivo clave siempre y cuando pudieran cuantificarse. Los primeros trabajos se ocupaban poco o nada de los procesos de producción y distribución, una carencia notable que solo recientemente se está corrigiendo con estudios sobre el trabajo de taller, los negocios de los libreros y la circulación de los ejemplares.

Las fuentes para la historia del libro se han diversificado, ampliándose más allá de la descripción material de los impresos. Un fenómeno tan particular como el procedimiento administrativo de concesión de licencias en Castilla, estudiado a partir de la documentación conservada por la Corona, ha permitido comprender mejor los pasos que siguen autores y editores como paso previo a la producción del libro (García Oro, 1995; Pérez García, 2006). De la producción editorial como empresa aún quedan bastantes cosas por averiguar, ya que el número de contratos de edición publicados con que contamos es limitado (Agulló, 1967, 1968, 1973; Peligry, 1981; 1987; Pérez Pastor, 1897). El panorama en cuanto a la producción material de los impresos parece más claro pues las topobibliografías que se llevan a cabo van resolviendo no 
pocos problemas. ${ }^{1}$ En cuanto al estudio de los inventarios de librerías se producen avances significativos, ahora bien, en el inventario no aparecen los rostros de los compradores pero sí algunos clientes que tienen deudas por los pagos a plazo de determinados libros. Con otras fuentes podemos aproximarnos a la dinámica del mercado, que debemos reconstruir con correspondencia, almonedas, testamentos, regalos o empeños (Peña Díaz, 1996: 197-226).

Desde otras disciplinas, fundamentalmente la historia de la literatura, se han realizado acercamientos notables a la historia del libro. En parte de-

1 Cristóbal Pérez Pastor. Bibliografía madrileña o descripción de las obras impresas en Madrid. Madrid: Tip. de los Huérfanos, 1891-1907. La reciente tesis de Yolanda Clemente San Román viene a completar y revisar esta bibliografía. Topobibliografía madrileña. La imprenta en Madrid en el siglo XVI (1566-1600). Kassel: Reichenberger, 1998. Trabajo que se complementa con el de Justa Moreno Garbayo. La imprenta en Madrid (1626-1650): Materiales para su estudio e inventario. Madrid: Arco/Libros, 1999. Julián Martín Abad, La imprenta en Alcalá de Henares (1502-1600). Madrid: Arco Libros, 1991. 3 v. Y su continuación La imprenta en Alcalá de Henares (1601-1700). Madrid: Arco Libros, 1999. 2 v. Fermín de los Reyes Gómez. La imprenta en Segovia (1472-1900). Madrid: Arco Libros, 1997. 2 v. Paloma Alfaro Torres. La imprenta en Cuenca (1528-1679). Madrid: Arco Libros, 2002. María Marsá Vila. La imprenta en La Rioja (siglos XVI-XVII). Madrid: Arco Libros, 2002. Y el esperado estudio de Mercedes Fernández Valladares. La Imprenta en Burgos: (1501-1600). Madrid: Arco/Libros, 2005. 2 v. 
El comercio de libros en Latinoamérica colonial ...

bido al desplazamiento del interés desde la interpretación de la crítica literaria tradicional de la obra hasta la de sus recepciones en distintos momentos -analizando la asimilación textual en una triple proyección de crítica textual, historial formal del libro y sociología retrospectiva de las prácticas de lectura-, que suponen un vuelco en la aproximación a lo cultural (Chartier, 1993 y 1994; Burke, 1993). Como también lo es el estudio de la cultura en sus estructuras de significación socialmente establecidas, que pueden percibirse en el conjunto de negociaciones colectivas puestas en marcha en los mecanismos de la sociabilidad, todo un entramado de relaciones donde podemos colocar al libro como una herramienta cultural portadora de relaciones. Estos enfoques permitirían una aproximación novedosa, que apenas comienza a aplicarse a los estudios de historia del libro en Latinoamérica. En ocasiones continúan envueltos en el formalismo de una tradición paleográfica, bibliográfica y de estudios de historia de las ideas que no rompe sus hielos metodológicos. La continuidad de tales investigaciones tiende a enredarse, en algunas ocasiones, en la mitología de los «orígenes» de las imprentas nacionales. En otros casos se producen trifulcas de poco fuste y abundante derroche en la discusión sobre los primeros impresos. El tema «eterno» de la caracterología de la conformación 
Complejidad y materialidad: reflexiones del Seminario del ...

cultural de la nación cubre otra área de obligado cumplimiento y pleitesía para los estudios académicos. No digamos la politología mitológica de las ideas de libertadores y otras problemáticas historiográficas más o menos cerradas en sus objetivos y blindadas en sus fines. La reflexión sobre la idea de América o el ser americano ha baldeado cualquier crítica que no aportara los bodoques necesarios para amurallar culturalmente la gran patria latinoamericana, en palabras estas últimas de Henríquez Ureña.

Los lingüistas y estudiosos de la literatura en la Colonia analizan variados aspectos de la implantación de la lengua castellana así como la incorporación de elementos de otras lenguas presentes en Latinoamérica como el italiano o el portugués, en el desarrollo de diferentes marcos de referencia en cuanto al proceso de aprendizaje (Adorno, 1998). Estos procesos educativos están ligados a una evangelización-educación que convierte, en nuestra opinión, el dominio colonial a través del refuerzo de la Corona y sus agentes en algo prioritario. La historiografía ofrece en estas cuestiones ambivalencias notables. Por una parte, un historia fuertemente ligada a las instituciones eclesiásticas que ha defendido la pureza espiritual de los evangelizadores y la propia evangelización a la par que ahondaban en la continuidad y la necesidad de tales intervenciones; 
a la otra orilla otros historiadores, alejados de las tesis oficializadas, se vienen a referir a tales procesos como parte de los instrumentos de coacción del dominio colonial. Al margen de polémicas muy enraizadas en las ideologías militantes nos parecen interesantes los estudiosos, de cualquier escuela, que profundicen en fenómenos de transferencia cultural y de intermediación cultural, sobre todo porque estos agentes están en conexión con la política de la Corona y los intereses de las clases dirigentes de la sociedad colonial. Además, forman parte del segmento que domina la transmisión cultural de la tradición europea en territorio americano, nos referimos, claro está, al clero y los letrados. Diversos estudios han proporcionado valiosas aportaciones en el campo de los estudios culturales. No nos detendremos en la larga historiografía sobre el tema, tan solo querríamos destacar algunas aportaciones recientes que vienen a entroncar estos estudios con el uso de los libros educativos, la enseñanza de la práctica de la lectura, y la lectura misma, fenómenos que nos parecen de especial interés para nuestro trabajo. En este terreno una de las aportaciones de interés es el trabajo desarrollado en el Seminario de Historia de la Educación de El Colegio de México, que publicó una Historia de la lectura en México (México, 1988). En este libro se exploraron las lecturas de evangelización por P. Gonzalbo con crite- 
rios de análisis de la abundante documentación sobre las prácticas y los usos del libro. Al trabajo de Gonzalbo le han seguido otros que, como el de Loreto López (2000), siguen la senda de estudio de las prácticas de lecto-escritura en comunidades de lectores. Este aspecto ha cobrado especial relevancia a la hora de explicar las redes de sociabilidad y la extensión de la lecto-escritura en amplios segmentos sociales, sobre los cuales se tenía una imagen sesga$\mathrm{da}$, proporcionada por la representación elaborada por las elites dirigentes. Esta recuperación de la historia del libro, y su reorientación hacia la historia de las prácticas de la lectura, va emparejada a otros estudios sobre la difusión y circulación de los libros, las bibliotecas particulares y la apropiación de los contenidos. ${ }^{2}$

2 Los trabajos de Robert Darnton, orientados hacia los libros franceses del siglo XVIII, le llevaron a plantearse en 1982 su artículo-pregunta What is the history of books?, un interrogante que provocó reacciones diversas. El texto puede encontrarse traducido en Historias. 44 (México, 1999), 3-24. De este mismo autor: «Historia de la lectura». (1991) En: Formas de hacer historia. Peter Burke, ed. Madrid: Alianza, 1994, pp. 177-208. De los cambios en la historia del libro también daba cuenta el trabajo de David D. Hall. "The History of the Book: New questions? New Answers?» The Journal of Library History. 21, 1 (1986), 27-38. Las prácticas de lectura son el objetivo del libro dirigido por Guglielmo Cavallo y Roger Chartier. Historia de la lectura en el mundo Occidental. Madrid: Taurus, 2001. Una aproximación a estos problemas que da cuenta del interés que despiertan 
El corte descriptivo de buena parte de los trabajos sobre bibliotecas o la mera descripción reiterada de listados, ahondan la distancia con las primeras intenciones metodológicas de este tipo de investigaciones que buscaban, no lo olvidemos, una historia total del libro rescatando sus múltiples facetas. En ocasiones, determinados acercamientos de otras disciplinas han proporcionado mejores enfoques; el estudio de la alfabetización es un terreno en el que, necesariamente, encontramos paralelismos, pues el dominio de la técnica de leer y su aprendizaje también han interesado a los historiadores de la educación que, como Viñao Frago, plantean un «análisis sociocultural de la alfabetización en su perspectiva histórica que lleva aparejado un trabajo interdisciplinar que se cifra en un enfoque de estudio de la alfabetización como una práctica social más... Lo que interesa pues, al historiador, es la evolución de dicha práctica, de los usos, maneras y modos de leer y escribir, de los contextos en los que se lee y escribe, así como de los materiales,

estos temas en José Manuel Prieto Bernabé. La seducción del papel. El libro y la lectura en la España del Siglo de Oro. Madrid: Arco/Libros, 2000. En otro sentido, es conveniente seguir la pista a los ensayos metodológicos y análisis de Ricardo García Cárcel. «La reciente historiografía modernista española». Chronica nova: Revista de historia moderna de la Universidad de Granada, 28 (2001), 185-219. 
Complejidad y materialidad: reflexiones del Seminario del ...

objetos o signos utilizados y del espacio social... en que tales actos se producen» (Viñao Frago, 1999: 106). Este programa de trabajo en torno a una tecnología específica y sus aplicaciones tiene algunas investigaciones ya desarrolladas en territorio americano, pero aún resultan insuficientes. Gonzalbo Aizpuru, Josefina Muriel y otras investigadoras han seguido las pistas de la historia de la educación en el terreno de la interpretación en clave cultural de la sociedad colonial.

La repercusión de la escritura en el mundo colonial está siendo revisada en diversos estudios. Sobre el universo cultural indígena los antropólogos e historiadores han aportado trabajos excelentes que analizan en detalle la incorporación de la escritura europea, en primer lugar como medio de salvaguarda de la memoria histórica, con las recreaciones que conlleva, y en segundo lugar, como medida de protección frente al dominio de los colonizadores, usando sus mismas armas, lo que se aprecia en el uso de la escritura en el ámbito jurídico para la defensa de sus tierras, fenómeno analizado con detalle por Serge Gruzinski (1993). En la otra vertiente encontramos la utilización de la escritura por los grupos detentadores del poder, que usan la escritura en el ámbito de las instituciones, en el conjunto de prácticas de lo escrito desarrolladas en la administración colonial y, por lo tanto, controlando tanto la producción docu- 
El comercio de libros en Latinoamérica colonial ...

mental como las relaciones y dependencias que se desprenden de sus usos (Chocano Mena, 1997). Este enfoque debe ser matizado con alguna precisión, son varios los frentes abiertos, desde quienes desarrollan metodologías que parten de la sociología (Herzog, 1995), a otros estudios más cercanos a los grupos sociales que producen los textos (v. gr. escribanos), con avances sobre la incidencia en el ámbito público-privado. Es el caso de quienes trabajan sobre protocolos notariales. Estos estudios de los intermediarios de la escritura como grupo, integrados en las redes de poder municipales, o bien como parte de una agrupación de notarios que defiende sus intereses, patrimonializando el cargo, sus beneficios y su transmisión hereditaria, permite situar el conjunto de los detentadores de la praxis documental oficial, pero sin olvidar el amplio marco para los usos sociales de la escritura relacionados con la educación y el aprendizaje de la escritura, lo que definirá usos diferenciados, desde las cartas particulares a las anotaciones mercantiles en los libros de cuentas. Los estudios dedicados a la educación están aportando novedades, la educación reglada ofertada por las instituciones eclesiásticas, auténtico monopolio cultural en la colonia, está dando paso a una considerable variedad de frentes educativos, que revelan cierta profesionalización de las tareas educativas primarias: los maestros de leer que enseñan rudimentos escolares y las 
Complejidad y materialidad: reflexiones del Seminario del ...

«mingas» o amigas que educan a las niñas dan muestra de la vitalidad educativa en los ámbitos urbanos. Un aspecto de interés en el mundo colonial es la escritura interpuesta o por intermediación, de la que existen numerosos testimonios. La posibilidad de acudir a un tercero para que redacte el documento que necesitamos es algo habitual en sociedades de corte tradicional con sistemas educativos deficitarios. Este medio proporciona a las clases populares una mediación en las relaciones con el poder y la burocracia. La facilidad para acceder a tales intermediarios adquiere un valor extraordinario en la comunicación del mundo indígena con las redes sociales impuestas en la colonia. Tales modalidades de escritura permiten a un analfabeto funcional «escribir» un texto y transmitirlo de forma correcta, para que cumpla las finalidades de comunicación. Esto incluye diversos usos coloniales de la escritura que abarcan desde una carta de amor a peticiones al monarca (Castillo Gómez, 1997; Petrucci, 1989; Halasz, 1997; González Sánchez, 2007).

\section{Bibliotecas, lectura y consumo de libros en América}

El estudio de las bibliotecas ha resultado objeto de las pesquisas de especialistas, generalmente vinculados al mundo de las bibliotecas, que iniciaron hace tiempo la reconstrucción genealógica de sus fondos 
El comercio de libros en Latinoamérica colonial ...

con libros antiguos, buscando el origen de las series bibliográficas incorporadas a bibliotecas nacionales o regionales en el acarreo de las sucesivas desamortizaciones y procesos de secularización de bienes eclesiásticos del siglo XIX. En pocas ocasiones es posible la reconstrucción del fondo originario del siglo XVI, la falta de catálogos contemporáneos deja, en no pocas ocasiones, como hipótesis la formación de estas bibliotecas. Por fortuna, para algunos casos concretos contamos con información complementaria; por ejemplo el caso de Santiago de Tlatelolco, si bien sería necesario rebajar un tanto el optimismo de Mathes respecto a las cifras de conjunto de la biblioteca, engrandecida en su afán de convertirla en la primera biblioteca académica americana (Mathes, 1982; Duclas, 1961). Tan solo contamos con una obra de conjunto para la época colonial en México. La Historia de las bibliotecas novohispanas es una recopilación de datos que rastrea información de catálogos de bibliotecas, sobretodo para el siglo XVIII (Osorio Romero, 1986; Roch, 1979). La mayor parte de la información es conocida y responde al tópico de ofrecer un panorama institucionalizado del devenir de los libros, en una línea descriptiva o bien el modelo empírico-positivista que encuentra en los estudios de las bibliotecas argentinas hasta los años setenta y que puede generalizarse a otros países (Parada, 2004). En estas 
obras el espacio que se dedica al análisis de los fondos de las bibliotecas conventuales tiene su sentido, pues los procesos desamortizadores han dejado un mayor rastro documental y bibliográfico. Para los siglos XVI-XVIII la información está más dispersa y apenas encontramos escuetas síntesis donde, de forma incomprensible, quedan al margen los estudios sobre la circulación y el uso de los libros. En conjunto, este tipo de estudios busca la reconstrucción de los orígenes de los fondos que han perdurado y se concretan en catálogos dejando de lado otras averiguaciones e indagaciones. ${ }^{3}$

Las bibliotecas particulares han sido objeto de variados acercamientos, faltando casi por completo los

3 Estas averiguaciones resultan de notable interés para los bibliotecarios, que necesitan reconstruir de forma detectivesca el fondo que tienen obligación de preservar. Un ejemplo de este tipo de trabajos es la tesis de licenciatura (inédita) de Jessica Marcelli Sánchez: La reconstrucción de un espacio de estudio: la Biblioteca del Convento de San Agustín de Guadalajara. Guadalajara, Jalisco: Universidad, 2005. Una parte de los estudios, no obstante, se centran en los orígenes de las bibliotecas de carácter nacional, como propone Nelson Schapochnik. «Un palacio de libros en los trópicos: metáforas, proyectos y la fundación de la Biblioteca Nacional en Río de Janeiro». Ayer, 58 (2005), 113-135. El caso argentino en Alejandro E. Parada, De la biblioteca particular a la biblioteca pública: libros, lectores y pensamiento bibliotecario en los orígenes de la Biblioteca Pública de Buenos: 1779-1812. Buenos Aires: Instituto de Investigaciones Bibliotecológicas, Facultad de Filosofía y Letras, UBA: Ediciones Errejotapé, 2002. 
estudios de conjunto. Hernández González elaboró una recopilación de los estudios sobre bibliotecas particulares españolas, analizando brevemente el contenido por materias y trazando las características en un comentario breve. Esta suma bibliográfica podría incorporar otros muchos ítems, en realidad tales recopilaciones tienen sentido como material de trabajo, pero quedan deslavazadas de su contexto, resultando una arquitectura sin lugar, pues tales recopilaciones, por muy útiles que resulten, dejan la sensación de fragmentación propia de los inventarios tomados de fuentes distintas, con cronologías dispares y en sitios diferentes. En cualquier caso, configura universos lectores, -entiéndase en vaguedad el término-, más que comunidades de lectores, que difícilmente pueden rastrearse en fondos bibliográficos tan alejados en intencionalidad de posesión y uso como los que se manifiestan en este trabajo (Hernández González, 1998). La publicación de inventarios como material de base trabajando la cantera de los archivos ha llevado a la acumulación asistemática de gran cantidad de listas. Podemos agrupar esta información por sectores profesionales, regiones, temáticas de las obras, etcétera. En todos estos campos hay investigaciones parciales realizadas (Millares Carlo, 1970; Solano, 1985). Para el caso americano, una ingente tarea de estudio de inventarios fue llevada a cabo por I. Leal en Libros y Bibliotecas en 
Complejidad y materialidad: reflexiones del Seminario del ...

Venezuela colonial (1633-1767) (Caracas, 1978). Se trata de una recopilación documental pionera que da información de la segunda mitad del siglo XVII en adelante, que puede complementarse con nuevos documentos de envíos tempranos de libros a Caracas (Rueda, 2005).

Mención aparte necesitan algunas investigaciones que reúnen los inventarios por la consideración casi sacralizada del libro, así como por el impulso de una voluntad culturalista de prestigiar saberes periclitados. La huida de métodos cuantitativos y la falta de una erudición fértil en materia cultural, tienen como consecuencia que encontremos el inventario sin más identificación bibliográfica. La publicación de inventarios ha sido la vertiente más socorrida, en una tarea constante de acarreo que recuerda las maneras positivistas de una parte de la historiografía enfrascada en estudios culturales. En este terreno las precauciones metodológicas resultan imprescindibles. Por fortuna, poco a poco, los trabajos sobre bibliotecas particulares insertan los contenidos en estudios más amplios, que interrelacionan la producción, el consumo, la posesión, etcétera (Turner, 1971 y otros citados en la bibliografía). Algunos estudios consiguen, de este modo, interrelacionar la posesión con otros parámetros como son la cultura gráfica de los poseedores de libros, la pertenencia a un grupo socio-profesional, el nivel de inversión en 
El comercio de libros en Latinoamérica colonial ...

libros respecto del total, etcétera. Es el caso del estudio de los libros de los peninsulares que mueren en América cuyos bienes son vendidos en pública almoneda realizado por González Sánchez (1989). En su trabajo analiza 186 inventarios con libros de peninsulares entre mediados del siglo XVI y finales del siglo XVII. Los resultados son de gran importancia, pues ofrecen una radiografía completa de la posesión del libro de los emigrantes europeos en Nueva España y el Perú. Eso sí, se trata de hombres en su mayoría, que aún no se habían asentado definitivamente en territorio americano. Un reflejo evidente de tal fenómeno es el porcentaje tan elevado de situaciones sin definición socio-profesional (el $25 \%$ del total) y el elevado tanto por ciento de clérigos de la muestra (un 26,8 \% del total).

En cualquier caso, los inventarios no agotan el caudal de lecturas. Los circuitos de interés del lector cuentan con otros muchos cauces posibles de información. En este sentido un estudio interesante es el de las lecturas en Costa Rica durante el siglo XIX. Molina Jiménez, tras estudiar inventarios post-mortem con libros poseídos que marcaban un continuismo cultural de la posesión del libro y la formación de bibliotecas, demuestra como los intereses culturales del momento cambiaron, derrotando hacia otros hábitos de consumo que aparecen en la prensa a través de los anuncios de venta de nove- 
Complejidad y materialidad: reflexiones del Seminario del ...

dades de literatura de importación (Molina Jiménez, 1992 y 1994). Estos estudios vienen a ser un buen indicador de las cautelas necesarias al interpretar los inventarios y la necesidad de contrastarlos con la prensa, las suscripciones, la crítica literaria y las demás ofertas culturales cuando tales fuentes resultan accesibles (González-Ripoll, 2000 e Inch C., 2000).

\section{La historiografía del comercio de libros con América}

Al tratar de los nuevos historiadores del libro, Darnton ya advertía del entronque con la historia social y preconizaba el interés de «descubrir el esquema general de la producción y el consumo de libros en largos períodos», precisamente es esta la línea de trabajo que más nos interesa abordar. ${ }^{4} \mathrm{Un}$ estudioso pionero, F. Rodríguez Marín, impartió

4 Robert Darnton. «¿Qué es la historia del libro?». Historias. 44 (México, 1999), p. 4. El interés por el comercio del libro es también compartido por Henri-Jean Martin. Pour une histoire du livre (XVe-XVIII ${ }^{e}$ siècle): cinq conférences. Napoli: Bibliopolis, 1987. Un excelente ejemplo de este interés por el comercio atlántico del libro lo ofrece el v. I de $A$ history of the book in America: The colonial book in the Atlantic World. Cambridge, 2000. Y el estudio de Edwin Wolf, II. The book culture of a colonial American city: Philadelphia books, bookmen and booksellers. Oxford: Clarendon Press, 1988. 
dos conferencias en 1911 en el Centro de Cultura Hispano-Americana en las que ofreció las primeras referencias a los envíos de libros del Quijote a América utilizando la documentación relativa a la flota de 1605 (Rodríguez Marín, 1911). Una notable aproximación fue la que realizó el incansable investigador Torre Revello en el Archivo General de Indias transcribiendo listas de libros. En sus trabajos sus intereses se centran, en gran medida, en las obras literarias y en la prohibición de exportarlas a América. Las 97 listas de libros que manejó en su obra El libro, la imprenta y el periodismo en América durante la dominación española (1940) se limitan a finales del siglo XVI, resultando su libro una de las primeras síntesis de conjunto de que disponemos. ${ }^{5}$

Algo similar ocurre con Irving A. Leonard. Este estudioso norteamericano, bibliotecario y crítico literario, realizó una revisión minuciosa del movimiento de libros en la Carrera de Indias y consiguió

5 José Torre Revello. «Lista de libros embarcados para Buenos Aires en los siglos XVII y XVIII». Boletín del Instituto de Investigaciones Históricas, X, VIII, 43-44 (1930), 29-50. También del mismo autor: «Un catálogo impreso de libros para vender en las Indias Occidentales en el siglo XVII». Boletín del Instituto de Investigaciones Históricas, VII, 40 (1929), 233- 253. Conviene recordar alguno de los excelentes trabajos de historia de la cultura, con especial interés en los jesuitas, de G. Furlong, Los jesuitas y la cultura rioplatense. Buenos Aires: Editorial Huarpes, 1946. 
Complejidad y materialidad: reflexiones del Seminario del ...

reconstruir el circuito comercial analizando con cuidado tanto la documentación del Archivo de Indias como la de los archivos de protocolos de México y Lima. A lo largo de varios artículos se dedicó a demostrar la llegada masiva de libros europeos a América. En sus trabajos se hace un balance de la repercusión de la literatura de entretenimiento peninsular. Leonard utilizó documentación original que permitió, con un método riguroso, por una parte revelar el importante trasvase de literatura del Siglo de Oro publicada en las prensas europeas a América y, por otro lado, barrer las renuencias de una parte de la crítica, realizando un «proceso de sana demolición» (Leonard, 1979: 14), frente a quienes consideraban que las autoridades españolas trataron de aislar a los colonos del pensamiento europeo, cuando era este pensamiento el que los sustentaba. En principio sus investigaciones se orientaron al escritor erudito Sigüenza y Góngora, del que elaboró una biografía. En 1933 dio a conocer los registros de navíos en un trabajo pionero y aún hoy en día poco conocido, titulado Romances of Chivalry in the Spanish Indies, with some Registros of Book Shipments to the Colonies (Berkeley, 1933). En los años siguientes publicó varios trabajos en la Hispanic Review dando a conocer otros documentos en 1934, 1940, 1941, 1942, 1943, 1944, 1947 y 1948 (Leonard, 1977). Estos trabajos quedaron recopila- 
dos en el libro más citado de Leonard: Books ot the Brave. Being an Account of Books and Men in the Spanish Conquest and Settlemet of the Sixteenth Century New World (Cambridge, 1949). El trabajo de Leonard traducido como Los libros del conquistador se mantiene como una visión de conjunto completa, con una correcta identificación y tratamiento de las listas. Es un autor que, además, contrastó la documentación de la Casa de la Contratación de Sevilla con otra de protocolos de Lima o Inquisición de México en el Archivo General de la Nación; de este modo su trabajo consiguió una amplia perspectiva, llegando incluso a estudios de historia cultural comparada con las colonias norteamericanas. ${ }^{6}$

Tras la Segunda Guerra Mundial tan solo disponemos de algunos trabajos parciales. Un autor, poco conocido y ocasionalmente citado, se dedicó a estos problemas de forma breve y concisa. Nos referimos a Juan Antonio Tamayo, que dio a conocer

6 A esta obra se une La época barroca en el México colonial (1959), es una recopilación de trabajos sobre el siglo XVII novohispano, la cual se ocupa de diversos personajes y aconteceres literarios teatrales y poéticos. Otro autor contemporáneo de Leonard es G. Lohmann Villena, uno de los primeros que trató de los libros en América en España tras el estudio de Rodríguez Marín de 1911, en su trabajo «Los libros españoles en Indias». Arbor. II, 6 (1944), 221-49. Completado y corregido en la reedición publicada en Historia de España. Estudios publicados por la revista Arbor. Madrid: CSIC, 1953, pp. 422-444. 
Complejidad y materialidad: reflexiones del Seminario del ...

el trasvase comercial de libros en un breve trabajo que ha pasado casi inadvertido (Tamayo, 1943). Kügelgen analizó un conjunto de envíos de libros de la flota de 1586 a Nueva España (Kügelgen, 1973). Castro Morales estudió la llegada a Puebla de los Ángeles de algunos envíos (Castro Morales, 1973) y en un artículo González Sánchez (1989) analizó varios envíos de libreros de la flota de 1605 , clasificándolos por materias siguiendo el esquema de la Bibliotheca Nispana Nova de Nicolás Antonio. El trabajo de Kügelgen es exhaustivo hasta la médula de la identificación; es un recorrido en un corte diacrónico que muestra la vitalidad del comercio de libros de la década de los ochenta. El trabajo de Castro Morales sigue la pista a varias listas de libros enviadas desde Europa contextualizando el circuito de distribución en Puebla en la segunda mitad del siglo XVI. El trabajo citado sobre la flota de 1605 ofrece una radiografía temática de varios envíos embarcados en Sevilla. González Sánchez siguió de cerca la senda de los títulos guía, que permite fijar como referencia la circulación de textos frecuentes en las listas. Este autor tiene otros trabajos que permiten conocer las librerías coloniales, las bibliotecas particulares de los peninsulares que viven en América y la circulación de libros hacia los virreinatos. González Sánchez publicó una monografía en la que se analiza detalladamente el co- 
El comercio de libros en Latinoamérica colonial ...

mercio de libros con la América española en los siglos XVI y XVII. Este libro aclara, por primera vez, muchos problemas de historia del libro relacionados con el mundo americano y la Carrera de Indias (González Sánchez, 1989). Estudió, de forma novedosa, el universo cultural del intercambio del libro en varias vertientes. Los materiales que utilizó fueron fuentes de archivo, en la mayor parte de los casos inéditas, y tuvo la notable cualidad de enfocar el libro en varios apartados netamente distintos que son a la vez complementarios: estudia la norma de control burocrática de la Casa de Contratación para el libro y el procedimiento inquisitorial de vigilancia analiza el papel de los mercaderes de libros en estos intercambios; $y$ da a conocer dos importantes fondos de librería de Lima; detalla en otro apartado la posesión de libros de peninsulares a través de inventarios post-mortem $\mathrm{y}$, con suma atención, deslinda los géneros embarcados a través de un muestrario de envíos de libros a América (González Sánchez, 2001).

El análisis de las fuentes le permite fijar mejor la fuente del Registro de Navíos de la Casa de la Contratación, documentación conservada en el Archivo General de Indias (Rueda Ramírez, 1999). El estudio de las hojas de registro y las memorias con las listas de títulos permiten un conocimiento de las obras que van en las bodegas de los barcos, bien 
Complejidad y materialidad: reflexiones del Seminario del ...

acondicionadas y protegidas del agua del mar (Rueda Ramírez, 2003). Las pesquisas sobre los libros embarcados en Sevilla y Cádiz pueden complementarse con las visitas de los comisarios inquisitoriales en los puertos americanos. De estos documentos conservamos una muestra representativa de lo que ocurrió en Veracruz, pues se visitaron los navíos en busca de libros prohibidos entre las pertenencias personales de pasajeros y otros tripulantes (Fernández del Castillo, 1982).

\section{El negocio del libro atlántico}

El negocio del libro es un terreno abonado para las interferencias de los poderes públicos. Aún más en el mundo moderno, sin libertad de imprenta y con una distribución de ideas sometida a las jerarquías estamentales. El análisis del comercio deberá, necesariamente, tener muy presente todas las estructuras administrativas y políticas que inciden en la distribución, lo cual conlleva conocer las disposiciones legales y de hacienda emanadas por la Corona y, en general, por toda la administración, desde los Consejos de Castilla y el de Indias hasta los virreyes o gobernadores. El corpus que podría resultar de las medidas civiles es un laberinto de disposiciones que puede ser rastreado en los trabajos de José García Oro y María José Portela Silva (2000) y en la recopilación de Fermín de los Reyes Gómez (2000); tam- 
El comercio de libros en Latinoamérica colonial ...

bién resultan útiles las herramientas elaboradas por la propia administración, como las sucesivas recopilaciones legales publicadas por orden real en tiempos de Carlos II y Carlos III. Nos referimos a la Nueva Recopilación y las sucesivas ediciones con añadidos de esta obra. La voluntad de control y centralización de licencias y privilegios de impresión fue muy evidente con la pragmática del 7 de septiembre de 1558 (Pérez García, 2006). El libro estuvo sometido a toda clase de controles previos a su impresión y, más tarde, también fue controlado en sus movimientos a través de las aduanas, en los puertos, etcétera. Aunque las medidas de vigilancia y represión recayeron en el Consejo de la Inquisición, que fue desarrollando su propio corpus legislativo de normas a través de las cartas acordadas y edictos. Era un mecanismo paralelo de vigilancia y control que incidía en el negocio de la librería a través de las visitas de navíos, las autorizaciones para el embarque de libros, etcétera. La necesaria puesta a punto de una maquinaria burocrática y la evolución de los objetivos que perseguía el tribunal inquisitorial, convertía a esta institución en un ente de control y censura muy peculiar, pues tenía herramientas de fijación de la ortodoxia, como son los índices de libros prohibidos, que actuaban como hitos señalando lo heterodoxo y censurable, con numerosos altibajos en la maquinaria de vigi- 
Complejidad y materialidad: reflexiones del Seminario del ...

lancia, como ocurrió en el caso de Lima estudiado por Guibovich Pérez (2003). La eficacia en el control del negocio de la librería y la efectividad de la censura son problemas no bien resueltos, el libro sobre censura en España que prepara Manuel Peña Díaz y el que prepara sobre México José Abel Ramos ayudarán a resolver estas cuestiones. Por el momento siguen resultando útiles los trabajos de Antonio Márquez (1980), V. Pinto Crespo (1983), José Pardo Tomás (1991) o Ángel Álcala (2001).

La venta de libros en el mundo moderno debe ser revisada. Los estudios enfrascados en la resolución de la reconstrucción de inventarios de librerías han resultado una herramienta fundamental. Ahora bien, el fuego de artificio retórico que conlleva la identificación de los libros en forma de notas no debe llevarnos a engaño. El fondo de librería es un stock de venta no realizada, como apunta $\mathrm{Ca}$ yuela para el caso del madrileño Alonso Pérez de Montalbán, un mercader de libros que negociaba habitualmente en la Carrera de Indias y que tenía más de 10,860 ejemplares de libros editados por él como no vendidos en 1648 (Cayuela, 2005); o bien es el reflejo, como mínimo, de un momento puntual del negocio de un librero en una ciudad determinada, como ocurre con Francisco de Aguilar en Sevilla en 1575, de nuevo un librero con importantes negocios en América (González Sánchez; Mai- 
El comercio de libros en Latinoamérica colonial ...

llard, 2003). Es necesario conocer los recursos humanos, financieros y empresariales de estos negocios. En este sentido es importante reconstruir tanto las redes familiares como las compañías, las actividades editoriales de los libreros o bien el papel de intermediarios o agentes del negocio del libro internacional que tenía un papel clave en el caso del negocio atlántico del libro. Los más importantes editores-libreros apenas han sido tratados escasamente, aunque contamos con algunas monografías que apuntan todo un complejo entramado económico tejido en torno a la edición y venta de libros desde las librerías medinenses, alcalaínas y madrileñas (Cayuela, 2005). Los negocios y sus implicaciones en la formación tanto del mercado español como americano pueden seguirse en algunos trabajos como el de Clive Griffin (1991) sobre los Cromberger sevillanos que ayuda a despejar numerosas dudas sobre el establecimiento de la imprenta en México, un aspecto sobre el que nuevos datos de los protocolos sevillanos permiten afinar los negocios tempranos de los libreros sevillanos con América (Álvarez Márquez, 2007), o el trabajo de William Pettas (2004) sobre los Junta de Salamanca, un estudio que permite establecer los contactos con los Giunti florentinos y los negocios del libro italiano en España. Un librero destacado, quizá uno de los que negoció con América a finales del XVI con más 
Complejidad y materialidad: reflexiones del Seminario del ...

intensidad, fue Benito Boyer. La tienda de libros que tenía en Medina del Campo fue estudiada por Vicente Bécares y Alejandro Luis Iglesias (1992). Otros estudios interesantes en este terreno se han centrado en el estudio de quiebras de compañías comerciales o bien asociaciones como la de la compañía de libreros de Salamanca estudiada por Bécares (2003) en unas fechas tan tempranas como 1530-1534, destinada a surtir de libros editados en el extranjero a los profesores de universidad, licenciados en diferentes disciplinas o teólogos. Las relaciones internacionales y el papel de los agentes extranjeros adquieren un relieve considerable, sobre todo si tenemos en cuenta que parte (importante) de los fondos de las librerías españolas y del negocio atlántico del libro estaba formada por libros extranjeros. En este sentido son destacados los estudios que han analizado, por ejemplo, esta presencia flamenca en Sevilla, como es el caso del agente Lippeo estudiado por Wagner (2002) o los trabajos de F. M. A. Robben (1990) y Vicente Bécares (1999). Los estudios sobre negocios de librería en ciudades como Sevilla con trabajos de N. Maillard y C. A. González Sánchez (2003) estudiando al librero Aguilar; Medina del Campo investigada por Rojo Vega reconstruyendo los negocios a través de la documentación notarial; Zaragoza trabajada por Esperanza Velasco de la Peña (1998); Valencia (Ber- 
El comercio de libros en Latinoamérica colonial ...

ger, 1987); Barcelona (Peña Díaz, 1997), etcétera, han contribuido a completar el panorama del circuito del libro y sus agentes.

El pulso al comercio del libro y a la situación del mercado se aventura difícil desde una sola fuente. Además, el enfoque analítico ha resultado útil y desde un punto de vista histórico impecable: transcripción paleográficamente cuidada, identificación de cada título y de sus posibles ediciones, valoración cuantitativa del conjunto, etcétera. Aun así, insistimos, el resultado es una radiografía de un paciente en un punto concreto de su recorrido, generalmente a la muerte del librero. No es en modo alguno un reflejo de sus actividades a lo largo de, en ocasiones, décadas. Esto es algo que no escapa a la atención de los historiadores que publican tales inventarios. Intentan suplir tales deficiencias con el testamento y fuentes notariales. En cualquier caso, un oficio como el de librero no es, en modo alguno, una actividad que se resuma y compendie en tienda abierta, es un negocio complejo y con vericuetos y retortas en el quehacer cotidiano. La necesidad convirtió a algunos en aventureros y a otros que pretendían instalarse en el negocio en ambulantes. Es más, las quejas de los libreros instalados permiten entrever conflictos que denotan una variedad de situaciones, sin ir más lejos uno de los primeros manuales de aprendizaje del oficio de librero que se 
Complejidad y materialidad: reflexiones del Seminario del ...

llevaron a la imprenta, el concreto L'art scientifique, pour connoitre et exercer le commerce de la librairie (Lyon, 1789) de François Los-Rios nos permite aventurarnos en los orígenes de un negocio de librería que comenzó con su protagonista visitando y vendiendo libros allí donde el público se congregara. La narración de estos inicios de sus andaduras de vendedor de libros no tienen desperdicio: «Je fus installé et reçu marchand, sans apprentissage, ni brevet de maîtrese; au moyen de quoi, j'eus la liberté d'entrer ... dans les cafés et autres lieux publics, comme corridors, cloîtres, galères».

En el caso español (y americano) hay un déficit en los estudios en un aspecto fundamental: los catálogos de venta de los libreros. Durante mucho tiempo el trabajo pionero de Rodríguez-Moñino apuntaba una carestía de inventarios y catálogos de venta de librerías y bibliotecas particulares. Algunas investigaciones recientes apuntan, sin embargo, a catálogos como el que imprimió el librero asentado en Madrid Simón Vassellini a finales del siglo XVI y es probable que los archivos nos deparen más sorpresas. Era un librero, no debemos olvidarlo, que logró una carta de naturaleza para comerciar con América y se enfrascó en 1608 en envíos comerciales de libros a través de la Carrera de Indias. En cualquier caso en España (y por lo que sabemos en América) no hay proyectos para la 
El comercio de libros en Latinoamérica colonial ...

edición de estos catálogos y la correcta identificación de los libros a la venta, bien sean catálogos de librería o bien los catálogos para la venta de librerías particulares que fueron habituales en Europa en el mundo moderno. En estos casos, se editaba el catálogo con una tirada corta destinada a dar a conocer bibliotecas con un fondo riquísimo y de difícil acceso en títulos y lenguas para un lector medio. Es una tarea que proporcionaría una panorámica de la venta complementaria a la que obtenemos de los inventarios post-morten y que, además, podría contrastarse con lo que sabemos de las almonedas públicas. Es más, no conocemos realmente la historia de la publicidad y la propaganda del libro moderno en España y América. Es una temática compleja, pero olvidamos que el catálogo de venta, importante, no es el único medio de publicitar el libro. En el siglo XVIII las gacetas incluían información de las novedades, bien las llegadas a la Corte o las que arribaban por barco desde Europa a México y otros lugares de América (López, 1990; Parada, 1998). El estudio conjunto (no aislado o parcial en cada localidad) permitiría conocer mejor y pulsar el mercado y sus intereses. Es otra tarea en parte pendiente (hay trabajos parciales, y algunos en marcha), pero faltaría una interpretación de conjunto y una puesta en común de los materiales bibliográficos localizados e identificados en estas publicacio- 
Complejidad y materialidad: reflexiones del Seminario del ...

nes periódicas. Es una investigación que permitió, por ejemplo, en Puerto Rico durante el siglo XIX contrastar el aparente continuismo de las bibliotecas particulares (anquilosadas y ligadas a unas lecturas muy limitadas temáticamente) y las novedades literarias recibidas en la isla y dadas a conocer en la prensa periódica, un fenómeno clave que se complementa con los catálogos editoriales impresos en América, que juegan un papel clave para la distribución en el interior de los nuevos países tras la Independencia (Parada, 2005).

Las redes de negocio y la ligazón de las redes comerciales con las de distribución de libros son otro asunto pendiente de una completa revisión. Tenemos abundante información, eso sí, dispersa y poco sistematizada, pero una completa ausencia de un cuadro coherente de la evolución del tráfico comercial del libro. El problema es relevante, pues es prácticamente imposible valorar correctamente el negocio en España y en el tráfico hacia América (y en el propio territorio americano) sin un conocimiento más certero de las redes. Esto conlleva un análisis de la prosopografía de los libreros (algo impensable dado el estado de las investigaciones) y una cuidada reconstrucción de las fases del negocio (algo que las obras de síntesis plantean de forma genérica). El panorama resulta, claramente, insuficiente cuando no fragmentario, dando lugar a un 
marco de relaciones de intercambio de libros que parecería ha surgido de la nada, cuando sabemos se sustenta en lazos familiares, en el negocio y en las de relaciones con los poderes públicos, el mundo letrado y el mercado de lectores. A poco que miremos las redes atlánticas, los negocios oceánicos de la Carrera de Indias, se configuran como el gran caudal de libros del Nuevo Mundo. Este caudal incide de manera muy evidente en toda la red de intercambio y puesta a la venta de los libros. Las luchas y los intereses encontrados de los libreros en pos de un control del tráfico internacional mostrarían las claves del abastecimiento de los virreinatos. La propia producción de las imprentas americanas está vinculada en forma de auténticos vasos comunicantes con la circulación del libro europeo en territorio americano. Se trata de fenómenos interrelacionados que no deberían, como hasta ahora, estudiarse por separado. En cierto modo, el libro europeo contribuye a construir y dar forma a la demanda, aunque también fortalece y amplía el número de lectores que, a su vez, inciden en la demanda y pueden convertir en rentable la edición de determinados textos. Este efecto boomerang de las redes atlánticas tampoco ha sido suficientemente valorado. Lo que está claro es que un libro producido localmente cierra el mercado a la producción foránea, este juego de relaciones complejas dependerá 
Complejidad y materialidad: reflexiones del Seminario del ...

de la relación de calidad/precio del producto, pero ante un producto competitivo los impresores locales (y los editores avispados) podían cambiar su diseño comercial de abastecimiento atlántico por una producción local. De hecho, la instalación de prensas en numerosas localidades es un asunto poco tratado, aunque resulta clarificador lo que hizo Cromberger y luego hicieron otros: colocar las prensas y editar lo que demandan las autoridades le permitió tener manos libres para enviar desde Sevilla miles de impresos para la venta, sin que la competencia de otras prensas pudiera hacerle sombra ni competir en el más jugoso negocio de la venta de libros, que era, en definitiva, el que proporcionaba una cierta liquidez. Sin olvidar que en estos asuntos los caudales obtenidos tenían que cubrir los gastos del envío de los libros desde Europa.

Tampoco tenemos una visión clara del mercado y su evolución. De hecho, las relaciones entre producción, distribución y consumo que se sucederían escalonadamente según los estudios de difusión de las ideas y los acercamientos tradicionales de la historia del libro no dan una idea acertada ni quizá completa de los problemas del circuito del libro y del impacto de la lectura, ni mucho menos permiten una reconstrucción del funcionamiento del mercado. La enrevesada trama entre manuscrito e impreso, la relación de vasos comunicantes del lec- 
El comercio de libros en Latinoamérica colonial ...

tor con los textos y la difícil trama de la relación oferta-demanda ofrecen un panorama rico y complejo que ayudó a la formación del mercado potencial de lectores coloniales. Cualquier automatismo producción-distribución-consumo que pudiera provenir de los trabajos tradicionales se enfrenta a problemas clave. El manuscrito puede preceder o incluso superar al impreso en la difusión de determinados textos, con intervenciones múltiples e incluso traducciones o adaptaciones que transformaban el texto original. De igual manera, en el caso americano podían darse adaptaciones de impresos para su traducción a lenguas indígenas, textos distribuidos en forma manuscrita o incluso oral, un medio, éste último, clave para difundir la doctrina.

La edición de un texto no era, en modo alguno, sinónimo de difusión o indicador de éxito. Y la penetración en el mercado no venía dada bajo ningún automatismo, cada impreso encontraba las vías de distribución específica y se adaptaba a las condiciones locales de cada lugar. Un libro podía llegar a través de la venta en librería con tienda abierta (por ejemplo, Diego López recibió en Puebla de los Angeles más de 1,600 ejemplares en siete envíos remitidos por Antonio de Toro, un librero sevillano) pero en otros lugares podía obedecer a una dinámica de ferias o vendedores ambulantes. Los libros podían recorrer caminos y llegar a numerosos luga- 
Complejidad y materialidad: reflexiones del Seminario del ...

res, allá donde el consumo demandaba algunas obras educativas (las cartillas) o a lugares de encuentro como romerías (con un interés evidente en este caso por las estampas y el libro devoto). El consumo y las posibilidades de acceso a los libros no son, por lo tanto, generalizables y deben reconstruirse sobre el terreno de acuerdo a la documentación pertinente en cada ocasión.

El mercado del libro no era estable, al contrario, era dinámico y se transformaba constantemente. Las tácticas y técnicas de negocio evolucionaban y la confrontación entre libreros e impresores por el control de la distribución no debe ser olvidada. El papel de unos y otros en la configuración del mercado y la necesidad de controlar las ediciones, la llegada de libros nuevos y la puesta en circulación de lo producido en las imprentas locales configuraba un marco de relaciones que daba cuenta de las limitaciones de acceso a los libros, sometidos a actividades de negocio y a redes de poder, de tal manera que la propia evolución de tales actividades comerciales podía tener un peso específico considerable en el abastecimiento. De hecho, podía producirse un cortocircuito en la relación de oferta-demanda en ambos sentidos, pues de igual manera que el mercado podía saturarse, se daban casos de falta de libros, una auténtica sed de nuevos impresos. 
El comercio de libros en Latinoamérica colonial ...

El mercado y sus problemas de constitución, evolución y cambio son un terreno difícil en el campo de los estudios de historia del comercio del libro. Es necesario conocer las redes, el material intercambiado y los negocios emprendidos con algunas evidencias de sus resultados, en clave de éxito o fracaso comercial. En este terreno pueden aventurarse momentos de cambio, pero la falta de estudios hace que debamos ser muy prudentes, supuestamente a mediados del XVI se produjo una paulatina llegada de libreros y se asentaron las primeras redes consolidadas de negocio que aprovecharon el tráfico atlántico para abastecerse (Nora, 2007). En realidad a finales del XVI el mercado de Nueva España estaba consolidado y controlado, al menos en parte, por libreros sevillanos, hasta tal punto que muchos libreros de Medina del Campo o Alcalá de Henares apostaron más por el mercado de Tierra Firme (Rojo Vega, 1992). Aún queda pendiente la revisión de la crisis del XVII (que sabemos no lo fue tal en todas partes), y cabe preguntarse, por lo tanto, qué ocurrió en América ante la caída, en cierto sentido, espectacular, del tráfico de libros como consecuencia de la quiebra del tráfico comercial de la Carrera de Indias. Y, también, ¿qué ocurrió en el siglo XVIII cuando se reactivaron, según ciertos indicios, los circuitos del libro? ¿Explicaría esto la formación de notables bibliotecas en esta 
Complejidad y materialidad: reflexiones del Seminario del ...

centuria? El tráfico de libros en el XVIII fue de notable alcance. Valga una pincelada para revelar un aspecto parcial al que convendría seguir la pista. En 1753 desde Ámsterdam se exportaron a los puertos españoles 11,538 balas de libros (Crespo Solana, 2000: 28). ¿Adónde fueron? ¿De qué libros se trataba? No lo sabemos. El dato, bien sea un apunte aduanero o bien una entrada en los libros de una compañía comercial, alerta de inmediato sobre un tráfico librario al que convendría seguir en toda su amplitud. Este tipo de señales dan cuenta del negocio y, los investigadores, deben afinar en las pesquisas para conocer el circuito y la red, el sistema completo y las personas que lo hacían posible. El mercado y sus mecanismos revelarían la buena salud del universo cultural, tanto el acceso a libros (no siempre disponibles ante la falta de tiendas de libros) como a su consumo. Podemos detectar tanto libros en busca de lectores, como lectores en busca de libros. La oferta de la Carrera de Indias pudo (o no) satisfacer tal encuentro. Las relaciones entre oferta y demanda son, en este sentido, una tarea pendiente de análisis con detalle que, creemos, no puede completarse sin tener presente las condiciones cambiantes de la producción a uno y otro lado del Atlántico. Las investigaciones se han centrado más en el tráfico, en los puertos, el comercio, la navegación, etcétera (Rueda, 2005). En concreto los 
El comercio de libros en Latinoamérica colonial ...

trabajos insisten en la reconstrucción del movimiento de navíos con libros, en el volumen del tráfico de volúmenes y sus fluctuaciones, tal como se observa en los trabajos de Gómez, centrados en la contabilidad de los cajones embarcados en el siglo XVIII y la interpretación de los totales de libros llegados a territorio novohispano, construyendo una singular, y discutible, teoría en torno al total de libros que llegaron a México a través de las vías oficiales de la Carrera de Indias mediante el cálculo de 108 libros por cajón (Gómez, 2007; 2008). El riesgo es evidente, el libro no tiene por que tener el mismo comportamiento que el resto de mercancías ni, quizá, podamos estudiarlo al margen de los talleres de impresión, los negocios de librería y toda la base económica de precios y monedas que hacen rentable la economía del libro atlántico. Las posibles estructuras diferenciadas de los mercados europeos y americanos también debieran llamar nuestra atención, así como las fronteras del negocio (ritmos de los envíos, límites en cuanto a la distribución de la mercancía, escasa alfabetización, etcétera) que, en su conjunto, ofrecen también no pocos elementos de valoración respecto a la penetración del libro y la posibilidad de puesta en mercado de los libros remitidos desde los puertos europeos.

Quizá debiéramos preguntarnos con más interés por la configuración de la relación entre la oferta y 
Complejidad y materialidad: reflexiones del Seminario del ...

la demanda, la adecuación de los modelos de negocio a las intereses cambiantes de los lectores, y a la propia evolución de los potenciales compradores de libros. El lograr dar con las claves de interpretación del interés en cada caso resulta una tarea necesaria, pues más allá de las redes, de las aduanas, de los puertos y los arrieros, encontramos lectores a la expectativa respecto de los libros que llegan y las noticias sobre novedades. La satisfacción del interés lector y la orientación, cambiante, de los gustos también orientarán el mercado y deberemos ser muy cautelosos en la definición de cada rasgo de estos lectores-consumidores que compran libros. En este sentido cualquier pista es clave. Estoy pensando en el caso de las deudas pendientes de cobro de los libreros que nos permiten definir el rostro de los compradores. El lograr identificar el consumo y sus características es, por lo tanto, una necesaria consecuencia del interés general por el circuito del libro. La investigación en este sentido deviene cualitativa y de los cajones y títulos contados pasamos a seguir los rastros y rostros de lectores concretos que nos permiten cuestionar las grandes cifras y las evaluaciones generales. Esta adaptación es un elemento esencial, de los lectores sin definición pasamos, en tal caso, a un interés de detalle que permite entender el consumo cultural y situar al libro logrando enfocarlo. De este modo el texto con ma- 
El comercio de libros en Latinoamérica colonial ...

yúscula distribuido como oferta adquiere el rasgo de un texto particular, en manos de un lector concreto. El paso es clave para articular correctamente la mirada sobre los negocios de los libreros y su capacidad (o no, pues hay casos de todo tipo) para adaptarse a los cambios, como ocurre con la entrada de la novela entre los libros preferidos desde finales del XVIII. Algunos editores ya vieron tal filón comercial y, por ejemplo, se dedicaron a reeditar clásicos del Siglo de Oro en el XVIII para un público lector refinado, a la par que otros editores europeos vieron un filón de venta en la reedición de las obras más eruditas. Cada público tendrá, por lo tanto, una diferente relación con los editores y libreros.

Otro aspecto clave relacionado con los potenciales lectores-compradores en el circuito comercial es la adecuación tanto del aspecto tipográfico y los grabados, así como del contenido textual, a los intereses o expectativas de un grupo de lectores. Esta correlación está resultando decisiva al integrar los estudios de bibliografía material con otros aspectos relacionados con los contenidos y su alteración para adaptarse a públicos específicos dentro de estrategias de venta y difusión que se relacionan con un consumo de lectura cada vez más extendido. Nos referimos a estudios específicos sobre los libros de caballería y su difusión hasta bien entrado 
Complejidad y materialidad: reflexiones del Seminario del ...

el siglo XVII estudiados por Lucía Megías, a las sueltas de comedias y la difusión del teatro leído, a las cartillas (estudiadas por Infantes, 1998; Infantes y Martínez Pereira, 2003), las relaciones de sucesos y el papel que juegan en la articulación política del espacio público, etcétera. En cada caso, los estudios del comercio y la difusión de estos textos, convertidos en auténticos géneros editoriales, resulta una tarea detectivesca en torno a las motivaciones de los públicos lectores. El universo tipográfico pasa a convertirse en una máquina de significar que debe ser interpretada a la luz de los usos y las prácticas culturales específicas del mundo hispánico, sin que sirvan meras trasposiciones de realidades socioculturales diferentes. En estos trabajos se da un interesante desplazamiento de los estudios cuantitativos hacia los cualitativos, lo cual resulta un complemento y un contrapeso a los estudios de producción y la mera cuantificación de la distribución en número de envíos, peso de los libros o número de cajones embarcados. De hecho, los estudios de MacKenzie dan unas claves esenciales de la repercusión del lector en la transformación del texto, en las posibilidades de interpretación y su valor pragmático para el lector. La relación entre la oferta y la demanda se convierte en un asunto recíproco de adaptaciones y cambios. El libro es visto, de este modo, como un producto editorial que incluye un 
texto y que tiene un autor, lo cual supone en sí mismo un cambio desde el inicio de la imprenta en el siglo XV, con notables consecuencias de la elaboración textual para el mercado. El libro como objeto de consumo es, en sí mismo, todo un entramado ajeno al mundo de la autoría y sometido a reglas de mercado y consumo simbólico, con efectos sentidos y repercusiones notables en el universo cultural del receptor. El mercado, por esto mismo, es clave para entender las transformaciones del texto hasta convertirse en libro impreso, con todo un complejo entramado paratextual (Cayuela, 1996).

La investigación sobre estos negocios del libro puede, en cierto modo, renovar los diferentes campos de trabajo de historia del libro introduciendo elementos novedosos. La puesta a punto de un tráfico atlántico de libros requería una movilización de recursos considerable en hombres y dinero. Aunque también suponía una ocasión para lograr llevar a tierras americanas un modelo cultural completo y trasplantarlo con todas las consecuencias. Este fenómeno cultural del libro en circulación tiene, por lo tanto, más vertientes de las meramente económicas y aunque el libro sea una mercancía embarcada también es, sin duda, una pieza clave para la formación de la colonia. El mundo de saberes y poderes americanos pudo sustentarse en esta trama de lecturas. El libro tiene, claro está, numerosas vertientes, pero el 
Complejidad y materialidad: reflexiones del Seminario del ...

comercio del libro puede contribuir a resolver algunas de las preguntas básicas en torno a la cultura de la Colonia y su evolución.

Otros aspectos que esperan un estudio detallado son la oferta cultural, la delimitación de aficiones lectoras, los cenáculos cultos o la actividad de la escritura y la definición de la autoría, y los problemas que provienen del espejo del mundo europeo, quizás en coyunturas diferentes, pero no necesariamente opuestas. Las etapas de cambio cultural en los virreinatos en el mundo moderno, con el comienzo de una época áurea de singular relieve, plantea conexiones del circuito atlántico de distribución con la literatura, el teatro o las artes plásticas coloniales, alimentadas ampliamente por las obras que aparecen detalladas en estos estudios.

\section{Apunte final}

Esta aproximación incompleta a los enfoques y el contexto del comercio del libro no ha tenido en cuenta todos los aspectos posibles, aunque nuestra intención era mostrar un avance de las líneas de trabajo que consideramos más interesantes. Pretendemos poner de relieve la evolución de los trabajos de historia cultural y social ligados a la producción, distribución y consumo de textos impresos, con especial hincapié en la repercusión de los estudios de la cultura escrita y la lectura, para dar cuenta del 
El comercio de libros en Latinoamérica colonial ...

contexto de los estudios realizados en torno al comercio del libro. Nada está agotado, ni las fuentes, ni tampoco, en modo alguno, las líneas de interpretación. El debate está servido, con algunas de las metodologías ya probadas y con los primeros resultados de estudios de comercio de libros disponibles, convendría unificar criterios, plantearse miradas cruzadas sobre las distintas realidades latinoamericanas y plantearse la posibilidad de una real colaboración en el estudio de las redes, los negocios de intercambio y los análisis de los libros remitidos, intercambiados o comerciados en el mundo americano durante la edad moderna. El modelo de The colonial book in the Atlantic World (2000) es un excelente acicate. En un futuro, esperemos que no muy lejano, una obra semejante podría ofrecer una imagen de conjunto del tráfico de libros en el otro Atlántico, el del mundo hispánico. Una obra de referencia en este sentido resultaría clave, sobre todo dadas las notables ausencias de estos estudios de historia del comercio librario con América en las síntesis elaboradas hasta el momento, como pueda ser la Historia ilustrada del libro español (1993) o la excelente Historia de la edición y de la lectura en España: 1472-1914 (2003). 
Complejidad y materialidad: reflexiones del Seminario del ...

\section{Bibliografía orientativa}

Adorno, Rodela. «La censura y su evasión: Jerónimo Román y Bartolomé de las Casas». Estudios de Cultura Nábuatl. 23 (1993), 263-296.

--. «Colonial Spanish American Literary Studies: 1982-1992». Revista Interamericana de Bibliografía. 38, 2 (1988), 167-176.

Agulló y Cobo, Mercedes. «Documentos sobre impresores y libreros madrileños de los siglos XVI y XVII». Anales del Instituto de Estudios Madrileños. II (1967), 175-213 y III (1968), 81-116.

--. «La Inquisición y los libreros españoles en el siglo XVII». Cuadernos Bibliográficos. 28 (1973), 143-52.

Alcalá, Ángel. «El control inquisitorial de intelectuales en el Siglo de Oro. De Nebrija al Índice de Sotomayor de 1640». En: Historia de la Inquisición en España y América, III: Temas y problemas. Dir. por Joaquín Pérez Villanueva y Bartolomé Escandell Bonet. Madrid: Biblioteca de Autores Cristianos; Centro de Estudios Inquisitoriales, 2000, pp. 829-926.

--. Literatura y ciencia ante la Inquisición española. Madrid: Laberinto, 2001. 
El comercio de libros en Latinoamérica colonial ...

Alcalá, Luisa Elena. «¿Pues para qué son los papeles...? Imágenes y devociones novohispanas en los siglos XVII y XVIII». Tiempos de América. Revista de Historia, Cultura y Territorio. 1 (1997), 43-56.

Álvarez Márquez, María del Carmen. La impresión y el comercio de libros en la Sevilla del Quinientos. Sevilla: Universidad de Sevilla, 2007.

Álvarez Márquez, María del Carmen y Gómez Gómez, Margarita. «Un pleito para la impresión de libros corales con destino a las Indias». Historia, Instituciones, Documentos. 25 (1998), 13-41.

Álvarez Santaló, León Carlos. «Librerías y bibliotecas en la Sevilla del siglo XVIII». En: Actas del II Coloquio de metodología histórica aplicada. La documentación notarial y la historia. Santiago de Compostela: Junta de Decanos de los Colegios Notariales de España; Secretariado de Publicaciones de la Universidad, 1984, t. II, pp. 167-185.

--. «La oferta de pautas de conducta cotidiana y la cimentación de valores en el libro devocional del $\mathrm{Ba}$ rroco. Un ensayo metodológico». Archivo Hispalense. 72, 220 (1989), 127-150.

--. «El libro de devoción como modelado y modelador de la conducta social: el Luz a los vivos de Palafox (1668)». Trocadero. 1 (1989), 7-25. 
Complejidad y materialidad: reflexiones del Seminario del ...

Álvarez Santaló, León Carlos. «Las esquinas aritméticas de la propiedad del libro en la Sevilla ilustrada». Bulletin Hispanique. 99 (1997), 99-134.

--. «Religiosidad moderna y cultura lectora en la España de los siglos XVI al XVIII». En: Estudios sobre Iglesia y Sociedad en Andalucía en la Edad Moderna. Eds. A. L. Cortés Peña y M. L. López-Guadalupe Muñoz. Granada: Universidad, 1999, pp. 225-265.

Ambrosio Sánchez, Manuel. «La biblioteca del predicador (en el siglo XVI). Renovación y continuidad». En: El escrito en el Siglo de Oro: Prácticas y representaciones. Dir. por Pedro M. Cátedra. Salamanca: Universidad, 1999, pp. 289-304.

Amelang, James S. «Algunas tareas y temas en la historia de la cultura urbana moderna». En: Cindad y mundo urbano en la época moderna. Dirs. Luis A. Ribot García y Luigi de Rosa. Madrid: Actas, 1997.

Antuñano Maurer, Alejandro de. «Los primeros intentos para controlar la circulación de libros en Nueva España». Libros de México. 3 (1986), 49-56.

Arenal, Electa y Schlau, Stacey. "Leyendo yo y escribiendo ella': The convent as intellectual community». Journal of Hispanic Philology. 13, 3 (1989), 214-229. 
El comercio de libros en Latinoamérica colonial ...

Arias González, Luis y Río Luelmo, Mercedes del. «Los avatares de la biblioteca privada de Nicolás Antonio (1687-1690)». Studia Histórica. Historia Moderna. IX (1991), 107-116.

Asensio, Eugenio. «Censura inquisitorial de libros en los siglos XVI y XVII. Fluctuaciones. Decadencia». En: El libro antiguo español: actas del primer coloquio internacional. Al cuidado de $\mathrm{M}^{\mathrm{a}}$ Luisa López Vidriero y Pedro M. Cátedra. Salamanca: Universidad de Salamanca, 1988, pp. 21-36.

Baranda, Nieves. «En defensa del Amadís y otras fábulas. La carta anónima al caballero Pero Mexía». Journal of Hispanic Pbilology. 15, 3 (1991), 221-236.

--. «Los lectores de Dioscórides: estrategias discursivas del doctor Laguna». Criticón. 58 (1993), 17-24.

--. «La literatura del didactismo». Criticón. 58 (1993), 25-34.

--. «¿Una literatura para la infancia en el siglo XVII?». En: La formation de l'enfant en Espagne aux XVTe et XVII siècles. Sous la direction d'Augustin Redondo. Paris: Publications de la Sorbonne, Presses de la Sorbonne Nouvelle, 1996, pp. 125-139. 
Complejidad y materialidad: reflexiones del Seminario del ...

Barnadas, Josep M. «La Biblioteca jesuita de Quito en el siglo XVII. Breve panorama analítico». Ibero-Americana Pragensia. 8 (1974), 151-161.

Bartolomé, Bernabé. «Tiempo, espacio y texto escolar». En: Historia de la acción educadora de la Iglesia en España, I: Edades Antigua, Media y Moderna. Madrid, 1995, pp. 917-963.

Bartolomé Martínez, Bernabé. «Las librerías e imprentas de los jesuitas (1540-1767): Una aportación notable a la cultura Española». Hispania Sacra. 40 (1988), 315-388.

Bataillon, Marcel. Erasmo y España. Estudios sobre la historia espiritual del siglo XVI. $2^{\mathrm{a}}$ ed. Madrid: Fondo de Cultura Económica, 1979.

Batllori, Miguel. «Las obras de Luis Vives en los colegios jesuíticos europeos del siglo XVI». En: Humanismo y Renacimiento. Barcelona: Ariel, 1987, pp. 125-149.

Baudot, Georges. Utopía e Historia en México. Los primeros cronistas de la civilización mexicana (1520-1569). Madrid: Espasa-Calpe, 1983. 
El comercio de libros en Latinoamérica colonial ...

Beardsley, Theodore S., Jr. Hispano-classical translations printed between 1482 and 1699. Pittsburgh, Pennsylvania: Duquesne University Press; Louvain: Editions E. Nauwelaerts, 1970.

--. «Spanish printers and the classics: 1482-1599». Hispanic Review. XLVII, 1 (1979), 25-35.

Béligand, Nadine. «Lecture indienne et chrétienté. La bibliothèque $\mathrm{d}$ 'un Alguacil de doctrina en Nouevelle-Espagne au XVIe siècle». Mélanges de la Casa de Velazquez. 31, 2 (1995), 21-71.

Becares Botas, Vicente. La compañía de libreros de Salamanca (1530-1534). Salamanca: SEMYR, 2003.

--. Arias Montano y Plantino. El libro flamenco en la España de Felipe II. León, 1999.

Becares Botas, Vicente e Iglesias, Alejandro Luis. La librería de Benito Boyer: (Medina del Campo, 1592). Valladolid: Consejería de Cultura y Turismo, 1992.

Bermúdez de Plata, Cristóbal. «Las obras de Antonio de Nebrija en América». Anuario de Estudios Americanos. III (1946), 1029-1032.

Bernand, Carmen y Gruzinski, Serge. Historia del Nuevo Mundo, II: Los mestizajes (1550-1640). Madrid: Fondo de Cultura Económica, 1999. 
Complejidad y materialidad: reflexiones del Seminario del ...

Blanco Sánchez, Antonio. «Inventario de Juan de Ayala (1556)». Boletín de la Real Academia Española. 67, 241 (1987), 207-250.

Block, David. «Missionary libraries on the Amazonian frontier: The Jesuits in Moxos, 1680-1767». The Journal of Library History. 18, 3 (1983), 292-303.

Bouza, Fernando. «Apuntes biográficos y análisis de la Biblioteca de un gran estadista hispano del siglo XVI: el presidente Juan de Ovando». Revista de Indias. 44, 173 (1984), 81-139.

--. Del escribano a la biblioteca. La civilización escrita europea en la Alta Edad Moderna (siglos XV-XVII). Madrid: Síntesis, 1992.

--. «Contrarreforma y tipografía. ¿Nada más que rosarios en sus manos?». Cuadernos de Historia Moderna. 16 (1995), 73-87.

--. «Para qué imprimir. De autores, público, impresores y manuscritos en el Siglo de Oro». Cuadernos de Historia Moderna. 18 (1997), 31-50.

--. Imagen y propaganda. Capítulos de historia cultural del reinado de Felipe II. Madrid: Akal, 1998.

Burke, Peter. «La nueva historia socio-cultural». Historia social. 17 (1993), 105-114. 
El comercio de libros en Latinoamérica colonial ...

Buxo, José Pascual y Melis, Antonio. Apuntes para una bibliografía crítica de la literatura bispanoamericana, I: Historias literarias. Firenze: Valmartina Editore, 1973.

Caballero Juárez, José Antonio. El régimen jurídico de las Armadas de la Carrera de Indias. Siglos XVI y XVII. México: UNAM, 1997.

Calvo, Hortensia. «The Politics of Print. The Historiography of the Book in Early Spanish America». Book History, 6 (2003), 277-305.

Calvo Poyato, José. «Un proceso a impresores y libreros en la Sevilla del Barroco». Archivo Hispalense. 70, 215 (1987), 61-76.

Cañigral Cortés, Luis de. «Luis Vives en México de la mano de Francisco Cervantes de Salazar». En: Memoria del Nuevo Mundo: Castilla-La Mancha y América en el Quinto Centenario. Coord. Pedro Miguel Ibáñez. [S.1.]: Universidad de Castilla La Mancha, [1992], pp. 281-287. 
Complejidad y materialidad: reflexiones del Seminario del ...

Carrato Mena, María Antonia. «Las iniciativas tecnológicas de la Subdirección General de Coordinación Bibliotecaria y el apoyo a la investigación en España: primer balance y perspectivas». Arbor, CLXXXII, 717 (2006).

$<$ http://arbor.revistas.csic.es/index.php/arbor/article/view/4/4>.

Carvalho, José Adriano de Freitas. Gertrudes de Helfta e Espanha, contribuiçao para estudo da história da espiritualidade peninsular nos séculos XVI e XVII. Porto: Instituto Nacional de Investigaçao Científica, 1981.

Castañeda, Carmen. «Cuando los libros y la imprenta llegan a Guadalajara». Libros de México. 38 (1995), 25-34.

--. «Circulación, censura y apropiación de libros al norte de la Nueva España». En: La formación de la cultura virreinal, I: La étapa inicial. Eds. Karl Kohut y Sonia V. Rose. Frankfurt: Vervuet, 2000, pp. 271-283.

--. «Libros en la Nueva España en el siglo XVI». En: La cultura del libro en la Edad Moderna. Andalucía y América. Ed. Manuel Peña Díaz. Córdoba: Universidad, 2001, pp. 271-288.

Castañeda Delgado, Paulino y Hernández Aparicio, Pilar. La Inquisición de Lima, (1570-1635). Madrid: Deimos, 1989. 
El comercio de libros en Latinoamérica colonial ...

Castañeda Delgado, Paulino y Hernández Aparicio, Pilar. La Inquisición de Lima, (1635-1696). Madrid: Deimos, 1995.

Castillo Gómez, Antonio. Escrituras y escribientes: prácticas de la cultura escrita en una ciudad del Renacimiento. Las Palmas de Gran Canaria: Fundación de Enseñanza de Educación a Distancia, 1997.

Castro Morales, Efraín. «Libros del siglo XVI en la ciudad de Puebla de los Ángeles». En: Libros europeos en la Nueva España a fines del siglo XVI: una contribución a la estratigrafía cultural. Wiesbaden: Franz Steiner Verlag, 1973, pp. 111-121.

Cayuela, Anne. Le paratexte au Siècle d'Or. Prose romanesque, livres et lecteurs, en Espagne au XVIIè siècle. Genève: Droz, 1996.

--. Alonso Pérez de Montalbán: un librero en el Madrid de los Austrias. Madrid: Calambur, 2005.

Chartier, Roger. «Las prácticas de lo escrito». En: Historia de la vida privada. Del Renacimiento a la Ilustración. Dirigida por Philippe Ariès y Georges Duby. Madrid: Taurus, 1989, t. III, pp. 113-161.

--. Libros, lecturas y lectores en la Edad Moderna. Madrid: Alianza, 1993. 
Complejidad y materialidad: reflexiones del Seminario del ...

Chartier, Roger.«De la historia social de lo cultural a la historia cultural de lo social». Historia social. 17 (1993), 97-103.

--. El orden de los libros. Lectores, autores, bibliotecas en Europa entre los siglos XIV y XVIII. Barcelona: Gedisa, 1994.

--. «'Cultura popular': retorno a un concepto historiográfico». Manuscrits. 12 (1994), 43-62.

--. El mundo como representación. Estudios sobre historia cultural. $2^{a}$ ed. Barcelona: Gedisa, 1995.

--. «Del libro a la lectura. Lectores populares en el Renacimiento». Bulletin Hispanique. 99, 1 (1997), 309324.

--. Entre poder y placer. Cultura escrita y literatura en la Edad Moderna. Madrid: Cátedra, 2000.

Chevalier, Maxime. «La Diana de Montemayor y su público en la España del siglo XVI». En: Creación y público en la literatura española. Madrid: Castalia, 1974, pp. 40-55.

--. Lectura y lectores en la España de los siglos XVI y XVII. Madrid: Turner, 1976. 
El comercio de libros en Latinoamérica colonial ...

Chartier, Roger. «Don Quichotte et son public». En: Livre et lecture en Espagne et en France sous l'Ancien Régime: colloque de la Casa de Velázquez. Paris: ADPF, 1981, pp. 119-123.

--. «La fortune du Romancero ancien (fin du XVe s.-debut du XVIIe)». Bulletin Hispanique. 90, 1-2 (1988), 187-195.

Chocano Mena, Magdalena. «Imprenta e impresores de Nueva España, 1539-1700: Límites económicos y condiciones políticas en la tipografía colonial americana». Historia social. 23 (Valencia, 1995), 3-20.

--. «Colonial Printing and Metropolitan Books: Printed Texts and the Shaping of Scholarly Culture in New Spain, 1539-1700». Colonial Latin American Historical Review. 6, 1 (1997), 69-90.

Clegg, Cyndia Susan. «Review». Renaissance Quarterly, Vol. 54, No. 1. (Spring, 2001), 221-245.

Cobos, Mercedes. Las Indias Occidentales en la poesía sevillana del Siglo de Oro. Sevilla: Universidad, 1997.

Crespo Solana, Ana. El comercio marítimo entre Amsterdam y Cádiz (1713-1778). Madrid: Banco de España, 2000 . 
Complejidad y materialidad: reflexiones del Seminario del ...

Cruickshank, D. W. «Some aspects of Spanish production in the Golden Age». The Library. 31, 1 (1976), $1-19$.

--. "Literature' and the book trade in Golden-Age Spain». The Modern Language Review. 73, 4 (1978), 799-824.

Dadson, Trevor J. Libros, lectores y lecturas. Estudios sobre bibliotecas particulares Españolas del Siglo de Oro. Madrid: Arco Libros, 1998.

Darnton, Robert. «De la sociologie de la littérature à 1'histoire de 1'édition». En: Bobême littéraire et révolution. Le monde des livres au XVIIIe siècle. Paris, 1983, pp. 71-109.

--. «Historia de la lectura». En: Formas de hacer historia. Ed. Peter Burke. Madrid: Alianza, 1994, pp. 177-208.

--. «QQué es la historia del libro?». Historias. 44 (México, 1999), 3-24.

Dexeus, Mercedes. «Las imprentas de la Corona de Aragón en la difusión de la literatura del Siglo de Oro». Edad de Oro. 12 (1993), 71-80.

--. «Diez años de historia del libro y las bibliotecas en España: 1983 1993». Boletín de la ANABAD. 44, 3 (1994), 149-160. 
El comercio de libros en Latinoamérica colonial ...

Dias, João José Alves. Craesbeeck, uma dinastia de impressores em Portugal. Elementos para o seu estudo. Lisboa: Associação Portuguesa de livreiros Alfabarrabistas, 1996.

Díaz Migoyo, Gonzalo. «Antiguallas mexicanas: escribir y leer crónicas en la Nueva España del XVI». Edad de Oro. 12 (1993), 81-93.

Domínguez Guzmán, Aurora. El libro sevillano durante la primera mitad del siglo XVI. Sevilla: Diputación, 1975.

--. «Veinte años de impresiones sevillanas (1551-1570)». Cuadernos Bibliográficos. 37 (1978), 1-57.

--. La proyección de América en las prensas españolas (1493-1700). Con la colaboración de Esperanza Bonilla Martínez. Sevilla: Kronos, 1992.

--. La imprenta de Sevilla en el siglo XVII: 1601-1650. (Catálogo y análisis de su producción). Sevilla: Universidad, 1992.

Duclas, Robert. Catálogo descriptivo de los libros impresos en la ciudad de Salamanca en el siglo XVI existentes en la Biblioteca Pública de Guadalajara. México, 1961.

Fernández, Stella Maris. La imprenta en Hispanoamérica. Madrid: ANABA, 1977. 
Complejidad y materialidad: reflexiones del Seminario del ...

Fernández del Castillo, Francisco. Libros y libreros en el siglo XVI. 2a ed. México, 1982.

Fernández de Recas, Guillermo S. «Libreros y libros de mediados del siglo XVII en México». Boletín de la Biblioteca Nacional. IX, 2 (1958); X, 2 (1959), 57-84; XII, 1-2 (1961), 51-65; XII, 3-4 (1961), 31-63.

Flor, Fernando R. de la. «La literatura espiritual del Siglo de Oro y la organización retórica de la memoria». Revista de Literatura. 45, 90 (1983), 39-85.

--. La Peninsula metafísica. Arte, literatura y pensamiento en la España de la Contrarreforma. Madrid: Biblioteca Nueva, 1999.

Frenk, Margit. Entre la voz y el silencio. (La lectura en tiempos de Cervantes). Alcalá de Henares: Centro de Estudios Cervantinos, 1997.

Frontón, Miguel Ángel. «La difusión del Oliveros de Castilla: apuntes para la historia editorial de una historia caballeresca». Dicenda. Cuadernos de Filología Hispánica. 8 (1989), 37-51.

Gacto, Enrique. «Sobre la censura literaria en el siglo XVII: Cervantes, Quevedo y la Inquisición». Revista de la Inquisición. 1 (1991), 11-61. 
El comercio de libros en Latinoamérica colonial ...

Gacto, Enrique. «Censura política e Inquisición: la Historia pontifical de Gonzalo de Illescas». Revista de la Inquisición. 2 (1992), 23-40.

--. «Sobre los fundamentos doctrinales de la censura inquisitorial». En: Dogmatismo e Intolerancia. Coord. E. Martínez Ruiz y M. de Pazzis Pi. Madrid: Actas, 1997, pp. 127-167.

Galán García, Agustín. El Oficio de Indias de Sevilla y la organización económica y misional de la Compañía de Jesús (1566-1767). Sevilla: FOCUS, 1995.

García Aguilar, Idalia. Miradas aisladas, visiones conjuntos: defensa del patrimonio documental mexicano. México: UNAM, CUIB, 2001.

García-Baquero González, Antonio. Sevilla y el Atlántico, 1717-1778. El comercio colonial español bajo el monopolio gaditano. $2^{a}$ ed. Cádiz, 1988. 2 v.

--. La Carrera de Indias. Suma de la contratación y océano de negocios. Sevilla, 1992.

García Fuentes, Lutgardo. El comercio español con América, 1650-1700. Sevilla: Diputación; Escuela de Estudios Hispano Americanos, 1980.

--. Los peruleros y el comercio de Sevilla con las Indias, 1580-1630. Sevilla: Universidad de Sevilla, 1997. 
Complejidad y materialidad: reflexiones del Seminario del ...

García Mauriño-Mundi, Margarita. La pugna entre el Consulado de Cádiz y los jenízaros por las exportaciones a Indias (1720-1765). Sevilla: Universidad de Sevilla, 1999.

García Oro, José. Los reyes y los libros. La politica libraria de la Corona en el Siglo de Oro (1475-1598). Madrid: Editorial Cisneros, 1995.

García Oro, José y Portela Silva, María José. La monarquía y los libros en el Siglo de Oro. [Alcalá de Henares] : Centro Internacional de Estudios Históricos Cisneros, 1999.

Gil, Juan. «El libro greco-latino y su influjo en Indias». En: Homenaje a Enrique Segura Covarsi, Bernardo Muñoz Sánchez y Ricardo Puente Brocano. Badajoz: Diputación Provincial, 1986, pp. 61-107.

--. «Libros, descubridores y sabios en la Sevilla del Quinientos». En: El libro de Marco Polo anotado por Colón... Ed., introd. y notas de J. Gil. Madrid, 1987, pp. I-LXVII.

Gómez Álvarez, Cristina. «Libros, circulación y lectores: de los religioso a lo civil (1750-1819)». En: Transición y cultura política. De la colonia al México independiente. Coords. Cristina Gómez Álvarez y Miguel Soto, México: UNAM, 2004, pp. 15-42. 
El comercio de libros en Latinoamérica colonial ...

Gómez Álvarez, Cristina. «Comercio y circulación del libro: Cádiz-Veracruz, 1750-1778». En: De ida y vuelta: América y España: los caminos de la cultura. Simposio internacional de la Asociación Española de Americanistas, Santiago de Compostela, 2 y 3 de septiembre de 2005. Ed. a cargo de Pilar Cagiao Vila, Eduardo Rey Tristán. Santiago de Compostela: Universidade de Santiago de Compostela, 2007, pp. 35-45.

--. «Comercio y comerciantes del libro en la Carrera de Indias: Cádiz-Veracruz, 1750-1778». Historia mexicana. 57, 3 (2008), 621-667.

Gonzalbo, Pilar. «La lectura de evangelización en la Nueva España». En: Historia de lectura en México. Seminario de Historia de la Educación en México. México: Ediciones del Ermitaño; El Colegio de México, 1988, pp. 9-48.

González Cañal, Rafael. «Don Quijote de la Mancha en tierras americanas». En: Memoria del Nuevo Mundo. Castilla-La Mancha y América en el Quinto Centenario. Coord. Pedro Miguel Ibáñez Martínez. [S.l.]: Universidad de Castilla La Mancha, [1992], pp. 205-213.

González González, Enrique y Gutiérrez Rodríguez, Víctor. Los diálogos de Luis Vives y la imprenta. Fortuna de un manual escolar renacentista (1539-1994). València : Institució Alfons el Magnànim, 1999. 
Complejidad y materialidad: reflexiones del Seminario del ...

González-Ripoll Navarro, $\mathrm{M}^{\mathrm{a}}$ Dolores. «Ocio, lecturas y escritura en la Ilustración cubana». Revista de Indias. LX, 219 (2000), 331-343.

González Rodríguez, Jaime. «La difusión manuscrita de ideas en Nueva España (siglo XVI)». Revista Complutense de Historia de América. 18 (1992), 89-116.

--. «Lecturas e ideas en Nueva España». Revista Complutense de Historia de América. 23 (1992), 39-74.

González Sánchez, Carlos Alberto. «La biblioteca de un pícaro indiano del siglo XVI: el cura Alonso Torres Maldonado». Investigaciones y ensayos. 36 (1987), 483-496.

--. «El libro y la Carrera de Indias: Registro de Ida de Navíos». Archivo Hispalense. 220 (1989), 93-103.

--. «Cultura y fortuna de un fiscal del Santo Oficio: el licenciado Juan Alcedo de la Rocha». Rábida. 7 (1990), 24-36.

--. «Los libros de los españoles en el virreinato del Perú, siglos XVI y XVII». Revista de Indias. 206 (1996), 7-49.

--. «Emigrantes y comercio de libros en el virreinato del Perú: Dos libreros limeños del siglo XVII». Historica. XXI, 2 (Lima, 1997), 171-205. 
El comercio de libros en Latinoamérica colonial ...

González Sánchez, Carlos Alberto. Los mundos del libro. Medios de difusión de la cultura occidental en las Indias de los siglos XVI y XVII. Sevilla: Diputación; Universidad, 1999. $270 \mathrm{p}$.

--. «La cultura del libro en el virreinato del Perú en tiempos de Felipe II». Colonial Latin American Review. 9, 1 (2000), 63-80.

--. «Un océano de libros: La Carrera de Indias en el siglo XVI». En: La cultura del libro en la Edad Moderna. Andalucía y América. Coord. Manuel Peña. Córdoba: Universidad, 2001, pp. 233-254.

--. Homo viator, homo scribens. Cultura gráfica, información y gobierno en la expansión atlántica (siglos XV-XVII). Madrid: Marcial Pons, 2007.

Griffin, Clive. The Crombergers of Seville: The bistory of a printing and merchant dynasty. Oxford, 1988. Tr. como Los Cromberger: La historia de una imprenta del siglo XVI en Sevilla y México. Madrid, 1991.

--. «La llegada de la imprenta a Hispanoamérica». En: Congreso Anglo-Hispano de la Asociación de Hispanistas de Gran Bretaña e Irlanda. Eds. Richard Hitchcock, Ralph Penny. Madrid: Castalia, 1994, t. 3, pp. 21-69. 
Complejidad y materialidad: reflexiones del Seminario del ...

Griffin, Clive.. «El inventario del almacén de libros del impresor Juan Cromberger: Sevilla, 1540». En: El libro antiguo español, IV: coleccionismo y bibliotecas (siglos XV-XVIII). Salamanca: Universidad, 1998, pp. 257-373.

Gruzinski, Serge. La colonización de lo imaginario: Sociedades indígenas y occidentalización en el México colonial. Siglos XVI-XVIII. México: Fondo de Cultura Económica, 1993.

Guibovich Pérez, Pedro. «Las lecturas de Francisco de Isasaga». Histórica. X, 2 (Lima, 1986), 191-212.

--. La Inquisición y la censura de libros en el Perú virreinal (1570-1813). Lima: Fondo Editorial del Gobierno del Perú, 2000.

--. Censura, libros e Inquisición en el Perú colonial, 1570-1754. Sevilla: CSIC; Universidad de Sevilla; Diputación de Sevilla, 2003.

Gutiérrez Luzardo, Hernando. «Circulación del libro en el Nuevo Reino de Granada». Historia. I, 2-4 (Bogotá, 1955), 73-84.

Halasz, Alexandra. The marketplace of print. Pamphlets and the public sphere in early modern England. Cambridge: Cambridge University Press, 1997. 
El comercio de libros en Latinoamérica colonial ...

Hampe Martínez, Teodoro. «La biblioteca del virrey don Martín Enríquez. Aficiones intelectuales de un gobernante colonial». Historia Mexicana. 142, XXXVI, 2 (1986), 251-271.

--. Cultura barroca y extirpación de idolatrías. La biblioteca de Francisco de Ávila (1648). Cusco: Centro de Estudios Regionales Andinos Bartolomé de las Casas, 1996.

--. Bibliotecas privadas en el mundo colonial: La difusión de las libros e ideas en el virreinato del Perú (siglos XVI-XVII). Vervuert: Frankfurt; Madrid: Iberoamericana, 1996.

Hernández González, $M^{a}$ Isabel. «Suma de inventarios de bibliotecas del siglo XVI (1501-1560)». En: El libro antiguo español, IV: coleccionismo y bibliotecas (siglos XV-XVIII). Salamanca: Universidad, 1998, pp. 375-446.

Herzog, Tamar. La administración colonial como un fenómeno social: La justicia penal de la ciudad de Quito (1650-1750). Madrid, 1995.

Huerga, Álvaro. «La obra intelectual de la Orden de Predicadores en América». En: Actas del I Congreso Internacional de los Dominicos y América. Madrid, 1988, pp. 689-714. 
Complejidad y materialidad: reflexiones del Seminario del ...

Inch C., Marcela. «Sobre libros y bibliotecas en Potosí, 1767-1822». Historia y cultura. 26 (2000), 75-102.

Infantes, Víctor. «En busca del lector perdido: La recepción de la poesía culta (1543-1600)». Edad de Oro. 12 (1993), 141-148.

--. «De la cartilla al libro». Bulletin Hispanique. 97 (1995), 33-66.

--. «Los pliegos sueltos del Siglo de Oro: hacia la historia de una poética editorial». En: Colportage et lecture populaire: Imprimés de large circulation en Europe, $X V I^{e}-X I X^{e}$ siècles. Sous la direction de Roger Chartier et Hans-Jürgen Lüsebrink. Paris: IMEC Éditions, 1996, pp. 283-298.

--. «Las ausencias en los inventarios de libros y bibliotecas». Bulletin Hispanique. 99, 1 (1997), 281-292.

--. «Ristras de papeles y rimas de libretes. Las lecturas populares en el cambio de siglo». En: La Cultura en Andalucía. Vida, memoria y escritura en torno a 1600. Eds. Pedro Ruiz Pérez y Klaus Wagner. Estepa: Ayuntamiento, 2001, pp. 129-142. 
El comercio de libros en Latinoamérica colonial ...

Jiménez, Nora. "Comerciantes de libros en la Nueva España en el siglo XVI. Perfiles y estrategias». En: Impresos y libros en la historia económica de México (siglos XVI-XIX), coord. María del Pilar Gutiérrez Lorenzo. Guadalajara, Jalisco: Universidad de Guadalajara, 2007, pp. 17-40.

Kügelgen, Helga Kropfinger-von. «Europäischer buchexport von Sevilla nach Neuspanien im Jahre 1586». En: Libros europeos en la Nueva España a fines del siglo XVI: una contribución a la estratigrafía cultural. Wiesbaden: Franz Steiner Verlag, 1973, pp. 1-105.

Leal, Ildefonso. Libros y Bibliotecas en Venezuela colonial (1633-1767). Caracas: Academia Nacional de la Historia, 1978. 2 v.

Leonard, Irving A. Romances of chivalry in the Spanish indies with some 'Registros' of shipments of books to the Spanish colonies. Berkeley, California, 1933.

--. «Bibliography». En: Homage to Irving A. Leonard: essays on hispanic art, history and literature. Michigan: Latin American Studies Center, 1977, pp. 11-18.

--. Los libros del conquistador. $2^{\mathrm{a}}$ ed. México: FCE, 1979. 
Complejidad y materialidad: reflexiones del Seminario del ...

Lohmann Villena, Guillermo. «Los libros Españoles en Indias». Arbor. II, 6 (1944), 221-249.

--. «Libros, libreros y bibliotecas en la época virreinal». En: La Biblioteca Nacional del Perú: apuntes para su historia. Lima, 1971, pp. 17-24.

López, François. «Estado actual de la historia del libro en España». Revista de Historia Moderna. 4 (1984), 9-22.

--. «Las obras extranjeras anunciadas en la "Gaceta de Madrid": Estudio diacrónico. Elementos de una estadística». Estudios de historia social, $52-53$ (1990), 303-311.

--. «Libros y papeles». Bulletin Hispanique. 99, 1 (1997), 293-307.

López-Vidriero, $\mathrm{M}^{\mathrm{a}}$ Luisa. «Los hechos y los rezos. Imprenta y circulación de libros en Indias». En: $E l$ inca Garcilaso y el mestizaje en Indias. Ed. Fernando Iwasaki Cauti. Montilla, 1996, pp. 93-107.

--. "Los estudios de historia del libro en España durante el siglo XX». La Bibliofilía. CII, 1 (2000), 123-135. 
El comercio de libros en Latinoamérica colonial ...

Loreto López, Rosalva. «Leer, contar, cantar y escribir. Un acercamiento a las prácticas de la lectura conventual. Puebla de los Ángeles, México, siglos XVII y XVIII». Estudios de Historia Novohispana. 23 (2000), 67-98.

Luján Muñoz, Jorge. «La literatura jurídica notarial en Hispanoamérica durante la colonia». Revista Interamericana de Bibliografía. 37, 3 (1987), 355-368.

Malagón-Barcelo, Javier. La literatura jurídica española del Siglo de Oro en la Nueva España. Notas para su estudio. México, 1959.

Márquez, Antonio. Literatura e Inquisición en España, 1478-1834. Madrid: Taurus, 1980.

Marrero Fente, Raúl. Al margen de la tradición: relaciones entre la literatura colonial y peninsular en los siglos XV, XVI y XVII. Madrid, 1999.

Mathes, Miguel. Santa Cruz de Tlatelolco. La primera biblioteca académica de las Américas. México: Secretaria de Relaciones Exteriores, 1982.

- -. «El libro europeo en Nueva España». En: El impacto del encuentro de dos mundos: Memorias 14 y 15 de octubre de 1987. [México, 1988], pp. 55-64. 
Complejidad y materialidad: reflexiones del Seminario del ...

Medina, José Toribio. Historia de la imprenta en los antiguos dominios españoles de América y Oceanía. Santiago de Chile: Fondo Histórico Bibliográfico José Toribio Medina, 1958. 2 v.

Millares Carlo, Agustín. «Bibliotecas y difusión del libro en Hispanoamérica colonial: Intento bibliográfico». Boletín Histórico. 22 (1970), 25-70.

Molina Jiménez, Iván. «'Azul' por Rubén Darío. El libro de moda. La cultura libresca del valle Central de Costa Rica (1780 1890)». En: Héroes al gusto y libros de moda: Sociedad y cambio cultural en Costa Rica 1750 1900). Editores Iván Molina Jiménez, Steven Palmer. San José: Provenir; Plumsock Mesoamerican Studies, 1992, pp. 137-167.

--. «De lo devoto a lo profano. El comercio y la producción de libros en el Valle Central de Costa Rica (1750-1850)». Jabrbuch für Geschichte von Staat, Wirtschaft und Gesellschaft Lateinamerikas. 31 (1994).

Moll, Jaime. «Diez años sin licencias para imprimir comedias y novelas en los reinos de Castilla: 1625-1634». Boletín de la Real Academia Española. LIV, CCI (1974), 97-103.

--. «Problemas bibliográficos del libro del Siglo de Oro». Boletín de la Real Academia Española. LIX, CCXVI (1979), 49-107. 
El comercio de libros en Latinoamérica colonial ...

Moll, Jaime. De la imprenta al lector. Estudios sobre el libro Español de los siglos XVI al XVIII. Madrid: Arco Libros, 1994.

--. «Los editores de Lope de Vega». Edad de Oro. 14 (1995), 213-222.

Montero Reguera, José. «La recepción del Quijote en Hispanoamérica (siglos XVII al XIX)». Cuadernos Hispanoamericanos. 500 (1992), 133-140.

Moraes, Rubens Borba de. «Livros e bibliotecas no Brasil colonial (1500-1808)». Revista Interamericana de Bibliografía. Vol. XXII (1972), 227-241.

Moreno Gallego, Valentín. «La huella impresa de Luis Vives en el Quinientos». Cuadernos de Historia Moderna. 16 (1995), 345-375.

Osorio Romero, Ignacio. Historia de las bibliotecas novohispanas. México: Dirección General de Bibliotecas, 1986.

Parada, Alejandro E. Cuando los lectores nos susurran: libros, lecturas, bibliotecas, sociedad y prácticas editoriales en la Argentina. Buenos Aires: Instituto de Investigaciones Bibliotecológicas, Facultad de Filosofía y Letras, Universidad de Buenos Aires, 2007. Parada, 2002 
Complejidad y materialidad: reflexiones del Seminario del ...

Parada, Alejandro E. El mundo del libro y de la lectura durante la época de Rivadavia: una aproximación a través de los avisos de la Gaceta Mercantil (1823-1828). Buenos Aires: Universidad de Buenos Aires, Facultad de Filosofía y Letras, Instituto de Investigaciones Bibliotecológicas, 1998.

--. «La nueva historia del libro y las bibliotecas en la Argentina: antecedentes, historia y periodización». Congreso Mundial de Bibliotecas e Información: $70^{\circ}$ Congreso General y Consejo de la IFLA. Bibliotecas: Instrumentos para la Educación y el Desarrollo. 22 al 27 de Agosto del 2004, Buenos Aires, Argentina. < http://www.ifla.org/IV/ifla70/index-s.htm > [Consulta: 04/05/2008].

--. Duportail Hermanos. El orden y la memoria en la librería de Duportail Hermanos: un catálogo porteño de 1829. Buenos Aires: Instituto de Investigaciones Bibliotecológicas, Facultad de Filosofía y Letras, Universidad de Buenos Aires, 2005.

Pardo Tomás, José. Ciencia y censura: la Inquisición española y los libros científicos en los siglos XVI y XVII. Madrid: CSIC, 1991. 
El comercio de libros en Latinoamérica colonial ...

Peligry, Christian. «Les éditeurs lyonnais et le marché espagnol aux XVI et XVII siècles». En: Livre et lecture en Espagne et en France sous l'Ancien Règime: colloque de la Casa de Velázquez. Paris: ADPF, 1981, pp. 85-95.

--. «Du manuscrit à l'imprimé: le contrat d'édition dans l'Espagne du Siècle d'Or». En: De l'alphabétisation aux circuits du livre en Espagne: XVIe XIXe siècles. Paris: Centre National de la Recherche Scientifique, 1987, pp. 333-343.

Peña Díaz, Manuel. El laberinto de los libros. Historia cultural de la Barcelona del Quinientos. Madrid: Fundación Germán Sánchez Ruipérez, 1997. 546 p.

--. Cataluña en el Renacimiento: Libros y lenguas, (Barcelona, 1473-1600). Lleida: Editorial Milenio, 1996.

Pérez de Colosia Rodríguez, María Isabel y Gil Sanjuan, Joaquín. «Inspección inquisitorial a los navíos y control de libros». Jabega. 25 (1979), 25-36.

Pérez García, Rafael M. La imprenta y la literatura espiritual castellana en la España del Renacimiento. Gijón: Trea, 2006.

Pérez Pastor, Cristóbal. «Escrituras de concierto para imprimir libros». Revista de Archivos, Bibliotecas, $M u$ seos. I (1897), 363-371. 
Complejidad y materialidad: reflexiones del Seminario del ...

Petrucci, Armando. «Prospettive di ricerca e problemi di metodo per una storia qualitativa dell' alfabestismo». En: Sulle vie della scrittura: Alfabetizzazione, cultura scritta e istituzioni in et moderna. A cura di Maria Rosaria Pelizzari. Napoli : Edizione Scientifiche Italiane, 1989, pp. 21-37.

Pettas, William. A Sixteenth-Century Spanish Bookstore: the inventory of Juan de Junta. Philadelphia : American Philosophical Society, 1995.

Rama, Carlos M. Historia de las relaciones culturales entre España y la América Latina. Siglo XIX. México: Fondo de Cultura Económica, 1982.

Ramos Soriano, José Abel. «Reglamentación de la circulación de libros en Nueva España». En: Seminario de Historia de las Mentalidades. Del dicho al hecho... Transgresiones y pautas culturales en la Nueva España. México: Instituto Nacional de Antropología e Historia, 1989, pp. 123-132.

--. «Inquisición y cultura novohispana. Repercusiones de la censura de libros». En: Inquisición novobispana. Ed. Noemí Quezada. México: UNAM; Universidad Autónoma Metropolitana, 2000, v. II, pp. 423-429.

Reyes Gómez, Fermín de los. El libro en España y América. Legislación y censura (siglos XV-XVIII). Madrid: Arco Libros, 2000. 2 v. 
El comercio de libros en Latinoamérica colonial ...

Ripodas Ardanaz, Daisy. La biblioteca porteña del obispo Azamor y Ramírez: 1788-1796. Buenos Aires: PRHISCO-CONICET, 1994.

Roch, Rosalind Z. «A History of Libraries in New Mexico: Spanish Origins to Statehood». The Journal of Library History. 14, 3 (1979), 254-273.

Rodríguez Marín, Francisco. El «Quijote»y Don Quijote en América. Madrid: Librería de los Sucesores de Hernando, 1911.

Rojo Vega, Anastasio. «El negocio del libro en Medina del Campo. Siglos XVI y XVII». Investigaciones Históricas. 7 (1988), 17-26.

--. «Los grandes libreros españoles del siglo XVI y América». Cuadernos Hispanoamericanos. 500 (1992), 115-131.

--. Impresores, libreros y papeleros en Medina del Campo y Valladolid en el siglo XVII. Valladolid: Consejería de Cultura y Turismo, Junta de Castilla y León, 1994.

Rueda Ramírez, Pedro. «Los libreros Mexía en el comercio de libros con América en los últimos años del reinado de Felipe II». Felipe II (1598-1988). En: Europa y la monarquía católica. [Actas del Congreso Internacional, 20-23 de abril de 1998]. Dir. José Martínez Millán. Madrid: Parteluz, 1998, t. IV, pp. 477-496. 
Complejidad y materialidad: reflexiones del Seminario del ...

Rueda Ramírez, Pedro. «La circulación de libros entre el viejo y el nuevo mundo en la Sevilla de finales del siglo XVI y comienzos del siglo XVII». Cuadernos de Historia Moderna. 22 (Madrid, 1999), 79-105.

--. «Mercaderes y libros en la Carrera de Indias a finales del reinado de Felipe II». En: VReunión Científica de la Asociación Española de Historia Moderna. Felipe II y su tiempo. Coord. José Luis Pereira Iglesias. Cádiz: Universidad; Asociación Española de Historia Moderna, 1999, pp. 565-572.

--. «La circulación de libros desde Europa a Quito en los siglos XVI-XVII». Procesos. Revista Ecuatoriana de Historia. 15 (2000), 3-20.

--. «En torno a las librerías sevillanas: almacenes de libros para Andalucía y el Nuevo Mundo». En: La Cultura en Andalucía. Vida, memoria y escritura en torno a 1600. Eds. Pedro Ruiz Pérez y Klaus Wagner. Estepa: Ayuntamiento, 2001, pp. 251-269.

--. «El control inquisitorial del libro enviado a América en la Sevilla del siglo XVII». En: La cultura del libro en la Edad Moderna. Andalucía y América. Ed. Manuel Peña Díaz. Córdoba: Universidad, 2001, pp. 255-270. 
El comercio de libros en Latinoamérica colonial ...

Rueda Ramírez, Pedro. «El comercio de libros en la Carrera de las Indias, 1601-1650». En: Carmen Castañe$\mathrm{da}$, coordinadora. Del autor al lector. I. La historia del libro en México y II. La bistoria del libro. México: CIESAS. CONACyT. Miguel Ángel Porrúa, 2002, pp. 45-69.

--. «Libros a la mar: El libro en las redes comerciales de la Carrera de Indias». En: Libro y lectura en la Península Ibérica y América. Ed. Antonio Castillo Gómez. [Valladolid]: Junta de Castilla y León, Consejería de Cultura y Turismo, 2003, pp. 189-207.

--. «La vigilancia inquisitorial del libro con destino a América en el siglo XVII». En: Grafías del imaginario. Representaciones culturales en España y América (siglos XVI-XVIII). Coords. C. A. González Sánchez y E. Vila Vilar. México: Fondo de Cultura Económica, 2003, pp. 140-156.

- -. «La Celestina camino de América. El libro en circulación en la Carrera de Indias (siglos XVI-XVII)». Celestinesca. 28 (2004), 101-116.

--. Negocio e intercambio cultural: El comercio de libros con América en la Carrera de Indias (siglo XVII). Sevilla: Universidad; Diputación de Sevilla; Escuela de Estudios Hispano-Americanos, 2005. 
Complejidad y materialidad: reflexiones del Seminario del ...

Rueda Ramírez, Pedro.. «Las rutas del libro atlántico: libros enviados en el navío de Honduras (1557-1700)». Anuario de Estudios Americanos. 64, 2 (2007), 61-85.

--. «El librero sevillano Antonio de Toro en el negocio del libro con América durante el siglo XVII». En: Impresos y libros en la bistoria económica de México (siglos XVI-XIX), coord. María del Pilar Gutiérrez Lorenzo. Guadalajara, Jalisco: Universidad de Guadalajara, 2007, pp. 41-75.

Sánchez Baena, Juan José. «Noticias sobre el mundo del libro en Cuba antes del desarrollo de la imprenta (1525-1763)». Contrastes. Revista de Historia. 9-10 (1994-1997), 181-205.

Schäfer, Ernesto. El Consejo Real y Supremo de las Indias. Su bistoria, organización y labor administrativa basta la terminación de la Casa de Austria. Sevilla, 1947. 2 v.

Solano, Francisco de. «Los libros del misionero en Guatemala». Missionalia Hispanica. 20, 60 (1963), 319-350.

--. «Fuentes para la historia cultural: Libros y bibliotecas de la América colonial». En: Ensayos de metodología bistórica en el campo americanista. Coordinados por Fermín del Pino Díaz. Madrid: Centro de Estudios Históricos, Departamento de Historia de América, 1985, pp. 69-84. 
El comercio de libros en Latinoamérica colonial ...

Sommer-Marhis, Andrea. «América en el teatro y en la fiesta». En: El teatro descubre América. Fiestas y teatro en la Casa de Austria (1492-1700). Madrid: Mapfre, 1992. Pág. 17-165.

Tamayo, Juan Antonio. «Viejos libros de España que cruzaron el mar». En: Ensayo de bibliografía maritima española. Barcelona: Diputación Provincial, 1943, pp. XLV-LI.

Tavares Bessone da Cruz Ferreira, Tania Maria. «Circulaçâo de idéias nas bibliotecas privadas do Rio de Janeiro, no final do oitocentos». En: Nuevas perspectivas teóricas y metodológicas de la historia intelectual de América Latina. Ed. Hugo Cancino Troncoco. Frankfurt am Main: Vervuert, 1999, pp. 251-267.

Tormo Sanz, Leandro. «Una biblioteca perdida entre los llanos del Mamoré». Missionalia Hispánica. 17, 51 (1960), 367-371.

Torre Revello, José. El libro, la imprenta y el periodismo en América durante la dominación Española. Buenos Aires : Instituto de Investigaciones Históricas, 1940.

--. «Lista de libros importados para Buenos Aires en los siglos XVII y XVIII». Boletín del Instituto de Investigaciones Históricas. X, 43-44 (1930), 29-50. 
Complejidad y materialidad: reflexiones del Seminario del ...

Trabulse, Elías. «Los libros científicos en la Nueva España, 1550-1630». En: Cincuenta años de Historia en México. Coordinadores Alicia Hernández Chávez y Manuel Miño Grijalva. México: El Colegio de México, 1991, v. II, pp. 7-37.

Turner, E. Daymond. «Los libros del alcaide: La Biblioteca de González Fernández de Oviedo y Valdés». Revista de Indias. 125-126 (1971), 139-198.

Uchmany, Eva Alexandra. «Inquisición y ciencia en el México colonial». En: Ciencia, vida y espacio en Iberoamérica. Coord. José Luis Peset. Madrid: CSIC, 1989, pp. 345-377.

Valda Martínez, Edgar A. «Sobre una biblioteca colonial potosina». En: El libro, espejo de la cultura. Estudios sobre la cultura del libro en Bolivia, dedicados a Werner Guttentang. Compilados por Josep M. Barnadas. Potosí: Los Amigos del Libro, 1991, pp. 59-73.

Villagómez, Liborio. «Un testimonio documental sobre el comercio del libro en la ciudad de México en 1577». Historias. 31 (México, 1993-1994), 173-180.

Viñao Frago, Antonio. Leer y escribir. Historia de dos prácticas culturales. México: Fundación Educación, Voces y Vuelos, 1999. 
El comercio de libros en Latinoamérica colonial ...

Wagner, Klaus. «Libros para el convento de Santo Domingo de Coyoacán». Separata de Historiografía y Bibliografía Americanista. 23 (Sevilla, 1979), 6 p.

--. «Guido de Lavezaris, genovés (1512-1582): De librero a gobernador de Filipinas». En: Tra Siviglia e Genova: Notaio, documento e commercio nell 'età colombiana. A cura di Vito Piergiovanni. Milano, 1994, pp. 379-391.

--. «Descubrimientos e imprentas». En: Viagens e Viajantes no Atlântico Quinhentista. Lisboa, 1996, pp. 233-242.

Zapata Gollán, Agustín. "Escuelas, maestros, beatas y libros». En: Tercer Congreso de Historia Argentina y regional: celebrado en Santa Fe y Paraná, del 10 al 12 de julio de 1975. Buenos Aires: Academia Nacional de Historia, 1977, t. IV, pp. 681-689. 
Complejidad y materialidad: reflexiones del Seminario del Libro Antiguo. La edición consta de 150 ejemplares. Coordinación editorial, Zindy E. Rodríguez Tamayo. Formación editorial, Carlos Ceballos Sosa. Centro Universitario de Investigaciones Bibliotecológicas/ UNAM. Fue impreso en papel cultural ahuesado de 90 gr. en Producciones Editoriales Nueva Visión, ubicados en Juan A. Mateos, número 20, Col. Obrera, México D. F. Se terminó de imprimir en el mes de abril de 2009. 